\title{
Az Állattani Közlemények 1-100. köteteinek tartalomjegyzéke Contents of the 100 volumes of Állattani Közlemények
}

Az alábbiakban az 1902-ben alapított Állattani Közlemények folyóirat azóta megjelent mind a száz kötetének teljes tartalomegyzékét közöljük, a számozott kötetek és füzetek sorrendjében. A füzeteken belül a cikkek a megjelenés sorrendjét követik, tehát az oldalszámok szerint sorakoznak egymás után. A közlemények szerzői és címei után megadjuk az adott cikk címét idegen nyelven (angolul, németül vagy franciául) is. Ha volt a cikknek idegen nyelvü összefoglalója (vagy legalább címe), akkor ez kerek zárójelben van, ha nem volt, akkor a jelen lista céljából angolra fordítottuk szögletes zárójelben. A Tartalomjegyzék megkülönböztetés nélkül tartalmazza a füzetekben megjelent megemlékezéseket, áttekintő cikkeket, rövid közleményeket, véleményeket és hozzászólásokat, valamint az irodalmi ismertetéseket is: ez utóbbiakat - szintén szögletes zárójelben - a [Book review.] bejegyzéssel láttuk el. Nem szerepelnek a Tartalomjegyzékben a nyomtatott, egészen rövid, technikai szerkesztői megjegyzések, és a füzetenként többnyire automatikusan ismétlődö szerzői útmutatók sem.

A Tartalomjegyzékhez idő és erőforrás hiánya miatt nem tudtunk szerzői név- és tárgymutatót összeállítani és csatolni. Az ilyen irányú kereséseket - meglátásunk szerint - a későbbiekben az online elérhető vagy a Közlemények honlapjáról letölthető elektronikus verzión alkalmazható számítógépes kereső algoritmusok fogják lehetővé tenni.

Köszönetnyilvánítás. A Tartalomjegyzék összeállítói, az Állattani Közlemények jelen szerkesztője és technikai szerkesztője itt szeretné köszönetét kifejezni mindazoknak, akik ebben a munkában részt vettek és a lista közlését lehetővé tették: MatuszKa ANGÉLA, NAGY ENIKő, PAPP ZsóFIA, Reszegi TÜNDE, SEBESTYÉN RÉKA, SZALAI ANDRÁS és TÖKE ANDREA.

\section{1. kötet -1902}

1. füzet:

Méhely Lajos: Beköszöntő. [Introduction.] $1-4$

Entz Géza: Állattani törekvések a multban és jelenben. [Zoological efforts in past and present.]

Méhely Lajos: A fölösszámú végtagok keletkezéséről. [About the origin of superflous limbs.]

19-34

Méhely Lajos: Magyarország huszonegyedik denevérfaja. [The $21^{\text {st }}$ bat species of Hungary.]

Hogyan írják nevüket a magyar szerzők? [How should Hungarian authors write their names?] 
2. füzet:

Méhely Lajos: Elmélkedve buvárkodjunk. [Let's study thoughtfully.] $35-38$

Horváth Géza: A magyar faunaterület határai. [The borders of the Hungarian fauna-region.] 39-43

Csiki Ernő: A magyar birodalom Anophthalmusai. [The Anophthalmus of the Hungarian Empire.] 43-58

Méhely Lajos: Lacerta taurica Pall., a magyar fauna új gyíkja. [Lacerta taurica Pall., a lizard new to the Hungarian fauna.]

$58-62$

Gorka Sándor: Az állatok psychikai életéröl. [About the psychic life of the animals.] 62-72

Entz Géza: Új véglénytani folyóirat (Archiv für Protistenkunde). [A new journal in protistology (Archiv für Protistenkunde).] ...................................................... 73-74

Méhely Lajos: Természetrajzi Füzetek, XXV. k., 1-2. füz.; Szerk. Mocsáry Sándor. [Book review.] 74-75

Kertész Kálmán: Szakosztályunk négyhavi működése. [Four months work of our section.] 75-76

3. füzet:

Méhely Lajos: Weismann új könyve. [Weismann's new book.] $77-80$

Szakáll Gyula: A földi kutya (Spalax typhlus Pall.) szeme. [The eyes of the mole rat (Spalax typhlus Pall.).] $80-91$

Csiki Ernő: A magyar birodalom Anophthalmusai. (Folytatás.) [The Anophthalmus of the Hungarian Empire. (Continued.)] 91-104

Gorka Sándor: Az állatok psychikai életéről. (Folytatás.) [About the psychic life of the animals. (Continued.)] $104-113$

Méhely Lajos: Empedokles világnézete. [Empedokles’ ideology.] .................................. 114

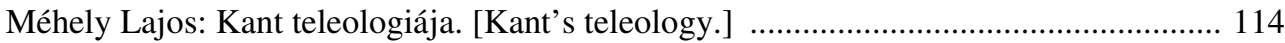

Méhely Lajos: A darwinismus küzdelmes napjaiból. [On the trialing days of Darwinism.] .

Vutskits György: Tiszavirág (Palingenia longicauda Oliv.) a Zala torkolatán. [Tisza mayfly (Palingenia longicauda Oliv.) at the mouth of Zala River.] $115-116$

Kertész Kálmán: Szakosztályunk ülései. [Sessions of our section.] 116

4. füzet:

Abafi Aigner Lajos: A mimicry. [The mimicry.] $117-126$

Szépligeti Győző: A palaearctikus Bracon-félék rendszere. 2. alcsalád: Exothecus-félék (Exothecinae). [Systematics of the Palearctic Braconidae. $2^{\text {nd }}$ subfamily: Exothecinae.] 126-137

Gorka Sándor: Az állatok psychikai életéről. (Befejező közlemény.) [About the psychic life of the animals. (Concluding article.)] 137-148

Méhely Lajos: Van-e Magyarországon áspiskígyó? [Does asp viper exist in Hungary?] $148-153$ 
Horváth Géza: Az V. nemzetközi zoologiai congressus. [The $5^{\text {th }}$ international congress of zoology.] 153-164

Kertész Kálmán: Szakosztályunk ülései. [Sessions of our section.] 164-165

\section{2. kötet - 1903}

1. füzet:

Méhely Lajos: A mimicry elve és jelentősége. [The theory and importance of mimicry.] 1-24

Kohaut Rezső: Magyarország bolhái. [The fleas of Hungary.] 25-46

Kertész Kálmán: Szakosztályunk ülései. [Sessions of our section.] 47-52

2. füzet:

Kohaut Rezső: Magyarország bolhái. (Befejező közlemény.) [The fleas of Hungary. (Concluding article.)] 53-68

Szakáll Gyula: A magyar földi kutya (Spalax hungaricus Nhrg.) hallókészüléke. [The hearing organ of the Hungarian mole rat (Spalax hungaricus Nhrg.).] 69-83

Rátz István: Új és kevéssé ismert hazai mételyek. [New and less known Hungarian trematods.] 83-88

Gorka Sándor: Ziegler, H. E.: Ueber den derzeitigen Stand der Descendenzlehre in der Zoologie. Jena, 1902, G. Fischer. [Book review.] 88-89

Gorka Sándor: v. Wettstein, R.: Der Neo-Lamarckismus und seine Beziehungen zum Darwinismus. Jena, 1903, G. Fischer. [Book review.] 89-90

Kertész Kálmán: Szakosztályunk ülései. [Sessions of our section.] 90-92

3. füzet:

Méhely Lajos: Adatok a delibláti homokpuszta és a Lokva-hegység faunájához. [Contributions to the fauna of the sandy stepp at Deliblat and the Lokva Mountains.] 93-105

Szépligeti Győző: A palaearctikus Bracon-félék rendszere. 8. és 9. alcsalád: Rhogas- és Rhyssalus-félék (Rhogadinae, Rhyssaloinae). [Systematics of the Palearctic Braconidae. $8^{\text {th }}$ and $9^{\text {th }}$ subfamilies: Rhogasinae and Rhyssalinae.] $105-114$

Csiki Ernő: Magyarország Hister-féléi. [Histeridae of Hungary.] $115-128$

Gorka Sándor: Koken, E.: Palaeontologie und Descendenzlehre. Jena, 1902, G. Fischer. [Book review.] $128-129$

Gorka Sándor: Rosa, D.: Die progressive Reduktion der Variabilität und ihre Beziehungen zum Aussterben und zur Entstehung der Arten. Bosshard ford. Jena, 1903, G. Fischer. [Book review.] 129-131

Gorka Sándor: Standfuss, M.: Zur Frage der Gestaltung und Vererbung auf Grund 28jähriger Experimente. Insekten-Börse, XIX. Jahrg., 1902. [Book review.] $131-132$ 
Gorka Sándor: Kassowitz, M.: Die Krisis des Darwinismus. Wissenschaftliche Beilage zum 15. Jahresbericht der Philosophischen Gesellschaft an der Universität zu Wien, Leipzig, 1902, J. A. Barth. [Book review.] 132-134

Kertész Kálmán: Szakosztályunk ülései. [Sessions of our section.] $134-136$

4. füzet:

Abonyi Sándor: A házi méh (Apis mellifica L.) bélcsövének alak- és élettani leírása. [Physiological description of the gut of the honeybee (Apis mellifica L.).] ........ 137-168

Vutskits György: A kurta baing (Leucaspius delineatus Heck.) természetrajza. [Natural history of the sunbleak (Leucaspius delineatus Heck.).] $169-188$

Tóth Zsigmond: Gegenbaur Károly emlékezete. [In memoriam Károly Gegenbaur.]

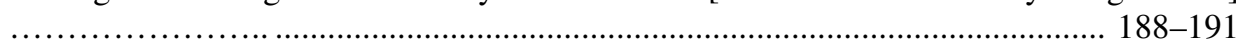

Méhely Lajos: Szakáll Gyula emlékezete. [In memoriam Gyula Szakáll.] .............. 191-192

Méhely Lajos: A gőték párosodása. [The copulation of newts.] 193

Gorka Sándor: De Vries, Hugo: Die Mutationstheorie. Versuche u. Beobachtungen ü. d. Entstehung von Arten im Pflanzenreich. Leipzig, 1901-1903, Veit et Comp. [Book review.] 194-197

Gorka Sándor: Jaekel, O.: Ueber verschiedene Wege phylogenetischer Entwickelung. Jena, 1902, G. Fischer. [Book review.] 197-199

Gorka Sándor: Simroth, H.: Die Ernährung der Tiere im Lichte der Abstammungslehre. Odenkirchen, 1901. (Breitenbach). [Book review.] 199-200

Gorka Sándor: Schwendener S.: Ueber den gegenwärtigen Stand der Descendenzlehre in der Botanik. Naturwiss. Wochenschrift, XVIII. Bd., p. 121. [Book review.] 200

5. füzet:

Entz Géza: Visszapillantás szakosztályunk eddigi müködésére. [Retrospect to the activities of our section.] 201-206

Horváth Géza: Konyhasós és szikes területeink rovarfaunája. [The insect fauna of our regions with saline soils.] 206-211

Méhely Lajos: Lacerta mosoriensis Kolomb., a magyar királyság új gyíkja, származástani kapcsolatában. [Lacerta mosoriensis Kolomb., a new lizard in the fauna of the Hungarian Empire, and its phylogeny.] $212-220$

Csiki Ernő: Magyarország Hister-féléi. (Befejező közlemény.) III. csapat: Saprinini. [Histeridae of Hungary. (Concluding article.) Group III: Saprinini.] 220-232

Dudinszky Emil: A festőkagyló (Unio pictorum L.) felemás héjairól. [On the asymmetrical shells of the painter's mussel (Unio pictorum L.).]

Méhely Lajos: Dr. Madarász Gyula: Magyarország madarai. A hazai madárvilág megismerésének vezérfonala. 170 eredeti szövegrajzzal és 9 mümelléklettel. Budapest, 1899_ 1903. (A Magyar Nemzeti Múzeum kiadása). [Book review.] 234-235 
Gorka Sándor: Jickeli, C.: Die Unvollkommenheit des Stoffwechsels als Veranlassung für Vermehrung, Wachstum, Differenzierung, Rückbildung und Tod der Lebewesen im Kampf ums Dasein. Berlin (Friedländer \& Sohn), 1902; Jickeli, C.: Die Unvollkommenheit des Stoffwechsels Grundprinzip für Werden und Kampf ums Dasein. Berlin (Friedländer \& Sohn), 1902. [Book review.] $236-238$

Kertész Kálmán: Szakosztályunk ülései. [Sessions of our section.] $238-240$

\section{3. kötet -1904}

1. füzet:

Kertész Kálmán: A magyarországi szúnyogfélék rendszertani ismertetése. (Systematische Bearbeitung der Culiciden Ungarns.) $1-75,86$

Gorka Sándor: A fényfogó szervek összefoglaló ismertetése. (Organe der Lichtempfindung.) [Book review.] $76-82$

Gorka Sándor: Hartmann Ed.: Die Abstammungslehre seit Darwin. Annalen der Naturphilosophie, II., 1903. p 285-355. [Book review.] $82-83$

Gorka Sándor: Szilády Zoltán: A magyar állattani irodalom ismertetése. III. kötet, 18911900. Budapest, 1903. A Kir. Magyar Természettud. Társulat kiadása. (Die ungarische zoologische Litteratur von 1891 bis 1900.) [Book review.] 83

Szakosztályunk ülései. (Sitzungsberichte.) $84-85,87-88$

2. füzet:

Tóth Zsigmond: Adatok a vöröshasú unka (Bombinator igneus Laur.) orrtokjának alaktani ismeretéhez. (Beiträge zur Morphologie der Nasenkapsel von Bombinator igneus Laur.) 89-98, 117

Schwalm A. Armin: A tavi denevér (Myotis dasycneme Boie) Magyarországon (Die Teich Fledermaus (Myotis dasycneme Boie) in Ungarn.) 98-102, 117-118

Kormos Tivadar: Új adatok a Püspökfürdő élő csigáinak ismeretéhez. (Neue Beiträge zur recenten Gastropoden-Fauna von Püspökfürdö.) $102-111,118-119$

Dudinszky Emil: Rendellenes kagylóhéjak. (Aberrante Schalenformen.) 112,119

Szilády Zoltán: Burckhardt, G.: Quantitative Studien über das Zooplankton des Vierwaldstättersees. Luzern, 1900. p. 1-309; Steuer, A.: Die Entomostrakenfauna der "alten Donau" bei Wien. Eine ethologische Studie. Mit einem Anhang: Zur Frage über Ursprung und Verbreitung der Entomostrakenfauna des Süsswassers. Zool. Jahrb. XV. 1901. p. 1-156. [Book review.] 113-114

Szilády Zoltán: A havasi tavak állatvilága. Zschokke: Die Tierwelt der Hochgebirgsseen. Basel, 1900. Denkschr. d. Schweiz. natf. Ges. XXXVIII, táblákkal s térképekkel. [Book review.] 114-115

Szakosztályunk ülései. (Sitzungsberichte.) 116,119 
3. füzet:

Entz Géza, ifj.: A Quarnero Tintinnidái. (Die Tintinniden des Quarnero.) ...... 121-133, 191

Soós Lajos: Magyarország Helicidái. (Die Heliciden Ungarns.) ...................... 134-184, 191

Kormos Tivadar: A Succinea (Lucena) oblonga Drp. eredetéröl. (Über den Ursprung der Succinea (Lucena) oblonga Drp.) 184,191

Gorka Sándor: A sejtmag chromatikus állományának szervezettségéről. Boveri Th.: Ergebnisse über die Konstitution der chromatischen Substanz des Zellkerns. Jena (G. Fischer), 1904. [Book review.] $185-188$

Szakosztályunk ülései. (Sitzungsberichte.) 188-190, 191-192

4. füzet:

Méhely Lajos: Egy új gyíkfaj Magyarországon. (Eine neue Eidechse aus Ungarn.) 193-210, 237-238

Gorka Sándor: Az ehető csiga (Helix pomatia L.) nyálmirigyeinek élettani szerepe. (Über die physiologische Funktion der Speicheldrüsen von Helix pomatia L.) 211-226, 238-239

Méhely Lajos: Nehring Alfréd †. (Erinnerung an Prof. Dr. Alfred Nehring.) .. 226-229, 239

Veith György: A koczkás sikló (Tropidonotus tesselatus Laur.) életéből. (Aus dem Leben der Würfelnatter [Tropidonotus tesselatus Laur.].) 229-230, 239-240

Horváth Géza: A máramarosi konyhasós területek rovarfaunájáról. (Über die Insektenfauna der Salzgebiete in der Máramaros.) 230,240

Tóth Zsigmond: Gondolatok az öröklésröl. Petrunkewitsch A.: Gedanken über Vererbung. Freiburg i. Br. (Speyer u. Kaerner), 1904. [Book review.] $231-233$

Gorka Sándor: A működési ingerek fajformáló hatása. Rabl C.: Über die züchtende Wirkung funktioneller Reize. Leipzig (W. Engelmann), 1904. [Book review.] . 233-235

Méhely Lajos: Az ember és az emberszabású majmok czombcsontjának müködéséből folyó alakulata. Walkhoff: Über den Oberschenkelknochen des Menschen und der Anthropoiden in seiner funktionellen Gestaltung. [Book review.] $235-236$

5. füzet

Méhely Lajos: A Mecsek-hegység és a Kapela herpetologiai viszonyai. (Die herpetologischen Verhältnisse des Mecsekgebirges und der Kapela.) ....... 241-289, 303

Csiki Ernő: A szongáriai cselőpók (Trochosa singoriensis Laxm.) elterjedése Magyarországon. (Die Verbreitung von Trochosa singoriensis Laxm. in Ungarn.) ....... 290-294, 303

Gorka Sándor: Napjaink vitalistikus törekvései. Verworn M.: Die vitalistischen Strömungen der Gegenwart. (Die Deutsche Klinik, Herausgegeben v. LeydenKlemperer. Berlin - Wien, 1904. 125. füzet, 251-268 lap). [Book review.] ...... 295-298

Tóth Zsigmond: A sejt élete és mechanikája. Rhumbler L.: Zellenmechanik und Zellenleben. Leipzig, I. H. Barth, 1904. [Book review.] 298-301

Szakosztályunk ülései. (Sitzungsberichte.) $301-302,304$ 


\section{4. kötet- 1905}

1. füzet:

Méhely Lajos: A származástan mai állása (első közlemény). (Über den heutigen Stand der Descendenzlehre.) $1-13,55-56$

Tunner J. Károly: A csíkbogár (Cybister laterimarginalis De Geer) hímivarkészülékének morphologiája és vérének osmotikus nyomása. (Die Morphologie des männlichen Geschlechtsapparates und der osmotische Druck des Blutes von Cybister laterimarginalis de Geer.) 14-38, 56-57

Kormos Tivadar: A püspökfürdői és a tatai Neritinák kérdéséhez. (Über Neritinen von Püspökfürdö und Tata.) $39-44,57$

Gorka Sándor: A lélekzés helye a sejtben. Verworn M.: Die Lokalisation der Atmung in der Zelle. Denkschriften d. Medizinisch-naturwissenschaftlichen Gesellschaft zu Jena, XI. Jena, 1904. p. 561-569. [Book review.] $44-46$

Gorka Sándor: Az emlősök szőrének származása. Pinkus, Felix: Über Hautsinnesorgane neben dem menschlichen Haar (Haarscheiben) und ihre vergleichend-anatomische Bedeutung. Archiv für mikroskopische Anatomie und Entwicklungsgeschichte, LXV., 1904. p. 121-179. [Book review.] $46-48$

Szakosztályunk ülései. (Sitzungsberichte.) $49-54,58-60$

2. füzet:

Méhely Lajos: A származástan mai állása (befejező közlemény). (26 rajzzal) (Über den heutigen Stand der Descendenzlehre.) 61-97, 111-113

Csiki Ernő: Adatok a hangyásztücsök (Myrmecophila acervorum PANZ.) ismeretéhez. (Beiträge zur Kenntniss von Myrmecophila acervorum PANZ.) 97-100, 113

Kormos Tivadar: Egyiptomi békalárvák. (Batrachierlarven aus Aegypten.) ... 100-103, 113

Tóth Zsigmond: A krapinai ősemberröl. Gorjanović-Kramberger: Der paläolithische Mensch und seine Zeitgenossen aus dem Diluvium von Krapina in Kroatien. Mittheil. d. anthropolog. Ges. in Wien, XXIX (1899), XXX (1900), XXXI (1901), XXXII (1902), XXXIV (1904). [Book review.] 104-107

Szakosztályunk ülései. (Sitzungsberichte.) $107-110,114-115$

3. füzet:

Méhely Lajos: A zoologusok Bernben megtartott VI. nemzetközi congressusának ismertetése. (Bericht über den in Bern abgehaltenen VI. internationalen Zoologen-Congress.) $117-125,163$

Soós Lajos: A puhatestűek származástanának főbb elvei. (Die Hautprinzipen der Mollusken-Phylogenese.) 126-139, 163

Tafner Vidor: Adatok Magyarország atkafaunájához. (Beiträge zur Acariden-Fauna Ungars.) $140-152,163$

Gorka Sándor: Farkas Kálmán emlékezete. (Erinnerung an Dr. Koloman Farkas.) $153-155,163$ 
Kormos Tivadar: A Melanopsis hungarica Korm. alkalmazkodásáról. (Über die Anpassung von Melanopsis hungarica Korm.) $155-156,164$

Gorka Sándor: Az élénken müködő sejtek chromidiális szervéről. Goldschmidt R.: Der Chromidialapparat lebhaft functionierender Gewebszellen. J. W. Spengel, Zoologische Jahrbücher, Abteil. f. Anatomie u. Ontogenie der Tiere. XXI. köt., 1. füzet, Jena, 1904. p. 41-140, 5 táblával és 16 szövegrajzzal. [Book review.] $156-162$

4- 5. füzet:

Horváth Géza: A tévesztő színek szerepe az állatvilágban. (Die Bedeutung der beirrenden Farben in der Natur.) $165-170,245$

Méhely Lajos: Adatok az állati szervezet formáló erőinek ismeretéhez. (Beiträge zur Kenntniss der formativen Kräfte des thierischen Organismus.) $171-185,245-246$

Soós Lajos: A puhatestűek származástanának főbb elvei. (Befejező közlemény.) (Die Hauptprinzipien der Mollusken-Phylogenese.) $185-197,246$

Entz Géza, ifj.: Az édesvízi Tintinnidák. (Über Süsswasser-Tindinnidin.) $198-218,246$

Tóth Zsigmond: Koelliker emlékezete (1817-1905). (Nachruf aun A. Koelliker.) $218-222,246$

Méhely Lajos: A zoologusok Bernben megtartott VI. nemzetközi congressusának ismertetése. (Befejezö közlemény.) (Bericht über den in Bern abgehaltenen VI. Internationalen Zoologen-Congress.) $222-235,246$

Wachsmann Ferencz: Az utolsó hód Magyarországon. (Der letzte Biber in Ungarn.) $235-236,247$

Gorka Sándor: A hangyák rabszolgatartó ösztönének eredete. Wasmann E.: Ursprung und Entwicklung der Sklaverei bei den Ameisen. Biologisches Centralblatt, XXV. kötet, 1905. p. 117-127, 129-144, 161-169, 193-216, 256-270, 273-292. [Book review.] $237-241$

Szilády Zoltán: Hofer Bruno: Handbuch der Fischkrankheiten. München, 1904. p. 1-359, 222 rajzzal és 18 színes képpel. [Book review.] 241

Szakosztályunk ülései. (Sitzungsberiche.) $241-244,247-248$

\section{5. kötet - 1906}

1-2. füzet:

Entz Géza: A patkányok bevándorlásának kérdése. (Über die Einwanderung der Ratten.) $1-25,103-104$

Soós Lajos: A tüdős csigák köpenyszerveinek alaktani viszonyairól. (Über die morphologischen Verhältnisse der Mantelorgane der Pulmonaten.) ...... 25-47, 104-105

Keller Oszkár: A csontos halak elö- és közbülső agyának alaktana. (Über die Morphologie des Zwischenhirns des Vorder- und der Teleostier.) $48-86,105$ 
Méhely Lajos: A gerinczesek zsigervázának elsődleges elemeiről Jaekel O. nyomán. (Über die Mundbildung der Wirbeltiere" (Sitzungs ber. d. Ges. naturf. Fr. zu Berlin, 1906, Nr. 1).) $86-94$

Csiki Ernő: A bolhák rendszertani helye. Semenov A.: Sur la position des Pulicides (Aphaniptera s. Siphonaptera auctorum) dans le systeme. (Revue Russe d'Entomologie, IV, 1904. p. 277-288). [Book review.] 94-96

Szakosztályunk ülései. (Sitzungsberichte.) 97-102, 106-108

3-5. füzet:

Abafi Aigner Lajos: Japánország lepkefaunájáról. (Über die Lepidopterenfauna Japans.) $109-115,155$

Szűts Andor: Adatok a földi giliszta kiválasztó szerveinek alak- és élettanához. (Beiträge zur Morphologie und Physiologie der Segmentalorgane des Regenwurmes.) $115-130,155$

Schwalm A. Amadé: A Tachyoryctes annectens Ths. faji jogosultsága. (Über die Artberechtigung von Tachyoryetes annectens Thomas.) $131-139,155$

Földváry Dezső: A csúcsosnyergű patkósdenevér (Rhinolopus Blasii Ptrs.) Magyarországon. (Rhinolophus Blasii Ptrs in Ungarn.) $140-146,155$

Entz Géza, ifj.: A levéllábú rákok egy óriása. (Über ein riesenhaftes Exemplar von Branchipus ferox) $147-148,155$

Tóth Zsigmond: Halál és szaporodás. Hartmann, Max: Tod und Fortpflanzung. München, E. Reinhardt, 1906. $148-150$

Szakosztályunk ülései. (Sitzungsberichte) $151-154,156$

\section{6. kötet - 1907}

1. füzet:

Méhely Lajos: A fákon élő patás állatokról. (Auf Bäumen lebende Hufthiere.) ...... 1-10, 49 Entz Géza, ifj.: A Peridineák szervezetéről. (II. és IV. tábla) (Die Organisation der Peridineen.) $11-30,49-50$

Szüts Andor: Adatok az édesvízi csővájó féreg (Tubifex tubifex Müll.) kiválasztó szerveinek ismeretéhez. (Beiträge zur Kenntniss der Excretions-organe von Tubifex tubifex Müll.) $31-36,50$

Méhely Lajos: Mágneses viharokat jelző állatok. (Erdmagnetische Stürme anzeigende Thiere..) $37-39,51$

Méhely Lajos: A viperaméreg élettani hatása. (Die physiologische Wirkung des Viperngiftes..) $39-42,51$

Soós Lajos: A pete szervképző anyagairól. Rabl Carl: Über "organbildende Substanzen" und ihre Bedeutung für die Vererbung. Leipzig, 1906, W. Engelmann. [Book review.] 
2. füzet:

Horváth Géza: Linné mint zoologus. (Linné als Zoologe.) $53-57,95$

Méhely Lajos: A "muralis-kérdés" megoldása. (Előleges közlemény). (Die Lösung der Muralis-Frage.) $58-62,95$

Pell Mariska: A halak oldalszervéről. (Irodalmi áttekintés.) (Über die Seitenorgane der Fische.) $63-82,95$

Méhely Lajos: A természetes kiválogatódás egy érdekes esete. (Ein interessanter Fall der natürlichen Auslese.) $83-86,95-96$

Tóth Zsigmond: A chromosomák keletkezése. Tellyesniczky K.: Die Entstehung der Chromosomen. Urban und Schwarzenberg, Berlin-Wien, 1907. [Book review.] .. 87-89

Szakosztályunk Linné-ünnepélye. [The Linne-celebration of our section.] 89-90

Szakosztályunk ülései. (Sitzungsberichte.) 90-92, 96

Szakosztályunk pünkösdi kirándulása. [Pentecost-excursion of our section.] 92-94

3. füzet:

Méhely Lajos: Archaeo- és Neolacerták. (Válasz Boulenger G. A. és Dr. Werner F. urak birálatára). (Archaeo- und Neolacerten.) 7-120, 138-139

Vutskits György: Halfaunánk egy új korcsa. (Ein neuer Fischbastard der ungarischen Fauna.) $120-128,139$

Szüts Andor: A nápolyi zoologiai állomáson használatos conserváló és rögzítő eljárásokról. (Die auf der zoologischen Station zu Neapel gebräuchlichen Methoden der Konservierung und Fixierung.) 129-132, 139-140

Soós Lajos: Az öröklékenység problémája. Hatschek B.: Hypothese der organischen Vererbung. Leipzig, 1905, W. Engelmann. [Book review.] 133-136

Szakosztályunk ülései. (Sitzungsberichte.) 137,140

4. füzet:

Méhely Lajos: Az egyiptomi patkány Magyarországon. (Die ägyptische Ratte in Ungarn.) 141-161, 198-199

Bolkay István: Adatok Gömör-Kishont vármegye herpetologiájához. (Beiträge zur Herpetologie des Komitates Gömör-Kishont.) $161-176,199$

Csiki Ernő: Az ürge bolhájáról. (Der Floh des Ziesels.) $177-179,199$

Bolkay István: A tavi béka (Rana ridibunda Pall.) faji jogosultsága. (Über die Artberechtigung von Rana ridibunda Pall.) 179-183, 199-200

Soós Lajos: Fejlődés és teremtés. Wasmann, E.: Der Kampf um das Entwicklungsproblem in Berlin. Freiburg i. B., Herder, 1907; Plate, L.: Ultramontane Weltanschauung und moderne Lebenskunde. Orthodoxie und Monismus. Jena, Fischer, 1907. [Book review.] 184-196

Szakosztályunk ülései. (Sitzungsberichte.) 196-197, 200 


\section{7. kötet - 1908}

1. füzet:

Méhely Lajos: A volt szerkesztő búcsuja. [Farewell of the editor.] $1-2$

Soós Lajos: Beköszöntő. [Introduction.]

$2-3$

Méhely Lajos: Két új poczokfaj a magyar faunában. (Zwei für Ungarn neue Wühlmäuse.) 3-14, 47-48

Rátz István: Húsevőkben élő Trematodák. (In Fleischfressern lebende Trematoden.) $15-20,48$

Soós Lajos: A Campylaea coerulans anatomiája és rendszertani helye. (Anatomie und systematische Stellung von Campylaea coerulans.) $21-25,49$

Leidenfrost Gyula: Új hal a Quarneroból. (Neue Fischart aus dem Quarnero.) ..... 26-30, 49

Papp Dezső: Vándorkagyló (Dreissensia polymorpha Pall.) a Zagyvából. (Wandermuschel (Dreissensia polymorpha Pall) aus dem Zagyvaflusse.) $30-32,49$

Soós Lajos: Új csiga-nem a magyar faunában. (Ein neues Schnecken-Genus in der ungarischen Fauna.) $32-34,49$

Csiki Ernő: Két újabb állattani kézikönyvről. [Book review.] $34-40$

Soós Lajos: A nemek keletkezéséről. Hertwig, R.: Weitere Untersuchungen über das Sexualitätsproblem. Verhandlungen der Deutschen Zoologischen Gesellschaft. 16. Bd. 1906. p. 90-111, 17. Bd. 1907. p. 55-73. [Book review.] 40-43

Soós Lajos: Ifj. Entz Géza: A Tintinnidák szervezete. Math. és Természettud. Közlemények, XXIX. kötet, 4. szám, Budapest, 1908. (Der Organismus der Tintinniden) [Book review.] $43-44$

Szakosztályunk ülései. (Sitzungsberichte.) $44-46,50$

2. füzet:

Horváth Géza: A Bostonban megtartott VII. nemzetközi zoologiai congressus. (Bericht über den VII. Internationalen Zoologischen Kongress in Boston.) $51-61,123$

Kordoss Gusztáv: A galamb embryonalis pehelytollainak fejlődése és morphologiája. (Die Entwicklung und Morphologie der Embryonaldunen der Taube.) $62-83,123$

Lósy József: A mételyférgek fejlődése. (Die Entwicklung der Distomeen.) $83-94,123$

Leidenfrost Gyula: Adatok a Quarnero zoogeographiájához. (Beiträge zur Zoogeographie des Quarnero.) 95-115, 123-124

Entz Géza, id.: Megemlékezés elhunyt zoológusokról. [Schmarda Lajos Károly; Leydig Ferencz; Möbius Károly]. (Gedenken an verstorbene Zoologen.) $116-117,124$

Tóth Zsigmond: A megtermékenyítés chemismusa. Loeb Jaques: Über den chemischen Charakter des Befruchtungsvorgangs und seine Bedeutung für die Theorie der Lebenserscheinungen. Leipzig, 1908. W. Engelmann. [Book review.] $118-121$

Szakosztályunk ülései. (Sitzungsberichte.) $121-122,124$ 
3. füzet:

Szilády Zoltán: Az élősködés fogalmának kiterjesztéséről. (Über die Ausdehnung des Begriffes des Parasitismus.) $125-144,179$

Leidenfrost Gyula: Újabb adatok a Quarnero és az Adria faunájának ismeretéhez. (Neuere Beiträge zur Kenntniss der Fauna des Quarnero und der Adria.) ....... 145-172, 179-180

Soós Lajos: Neresheimer, E.: Die Mesozoen. Zoologisches Zentralblatt, 15. Bd., 1908. p. 257-312. [Book review.] $173-176$

Szakosztályunk ülései. (Sitzungsberichte.) $177-178,180$

4. füzet:

Méhely Lajos: Az élősködés fogalmáról. (Über den Begriff des Parasitismus.) $181-185,235-236$

Koczián Lajos: A főemlősök szemüregének szerkezetéről. (Über den Bau der Augenhöhle der Primaten.) $186-214,236$

Entz Géza, ifj.: A Nyctotherus piscicola szervezeti viszonyairól. (Die Organisationsverhältnisse von Nyctotherus piscicola.) 215-226, 236-237

Gorka Sándor: A biogenetikai alaptörvény mai értelmezése. Hertwig, Oscar: Das biogenetische Grundgesetz nach dem heutigen Stand der Biologie. Internationale Wochenschrift für Wissenschaft, Kunst und Technik, 1. Jg., 1907., Nr. 2. und 3.. [Book review.] 226-229

Tóth Zsigmond: A gerinczesek fejének phylogenetikai fejlődése. Ziegler, Heinrich Ernst: Die phylogenetische Entstehung des Kopfes der Wirbeltiere. Jen. Zeitschr. für Naturw., XLIII. Bd., N. F. XXXVI. Bd., 1908. p. 653-684. [Book review.] $229-232$

Wachsmann Ferencz: Csiki Ernő: Magyarország bogárfaunája. Vezérfonal a magyar szent korona országainak területén elöforduló bogarak megismerésére. Budapest, 1905-1908. [Book review.]

Szakosztályunk ülései. (Sitzungsberichte.) 233-234, 237-238

\section{8. kötet - 1909}

\section{1-2. füzet:}

Rátz István: Az izmokban élősködő véglények és a magyar faunában előforduló fajaik.(Die Sarcosporidien und ihre in Ungarn vorkommenden Arten.) $1-37,91-95$

Entz Géza, ifj.: A magyarországi folyami rákokról. (Első közlemény.) (Über die Flusskrebse Ungarns.) $37-52,95$

Bolkay István: A khinai béka (Rana chinensis) systematikai értéke. (Der systematische Werth von Rana chinensis.) $53-68,95$

Leidenfrost Gyula: A Quarnero Munidái. (Die Muniden des Quarnero.) $68-74,95-96$ 
Hankó Béla: Adatok a madarak Fabricius-féle mirigyének alak- és élettanához. (Első közlemény). (Beiträge zur Morphologie und Physiologie der Bursa Fabricii der Vögel.) $74-82,96$

Lendvai János: Új készülék az Infusoriumok rögzítéséhez és festéséhez. (Ein neuer Apparat zur Fixirung und Färbung von Infusorien.) $82-84,96$

Csiki Ernő: A fossilis rovarok. Handlirsch, Anton: Die fossilen Insekten und die Phylogenie der rezenten Formen. Leipzig, 1906-1908. (IX+VI+1430 p., 51 Taf.). [Book review.] 84-89

Szakosztályunk ülései. (Sitzungsberichte.) 90

3. füzet:

Entz Géza, ifj.: A magyarországi folyami rákokról. (Második közlemény.) (Über die Flusskrebse Ungarns.) 97-110, 147

Hankó Béla: Adatok a madarak Fabricius-féle mirigyének alak- és élettanához. (Befejező közlemény.) (Beiträge zur Morphologie und Physiologie der Bursa Fabricii der Vögel.) $111-119,147$

Szüts Andor: Magyarország Lumbricidái. (25 szövegrajzzal) (Die Lumbriciden Ungarns. (Mit 25 Textfig.)) $120-142,147-148$

Soós Lajos: A rovarok átalakulása. Deegener, P.: Die Metamorphose der Insekten. Leipzig und Berlin, 1909. [Book review.] $143-145$

Szakosztályunk ülései. (Sitzungsberichte.) $145-146$

4. füzet:

Entz Géza, ifj.: A magyarországi folyami rákokról. (Befejező közlemény.) (Über die Flusskrebse Ungarns.) 149-163, 198-199

Köpe Győző: A Paludina vivipara helyzetérző szervéről. (Die Statocyste von Paludina vivipara.) 164-176, 199

Szilády Zoltán: Az élősködés fogalmának kiterjesztéséről. (Válasz Méhely Lajosnak). (Über die Ausdehnung des Begriffes des Parasitismus.) (Erwiderung an L. Méhely.) 176-183, 199

Méhely Lajos: Válasz Szilády Zoltánnak. (Antwort an Z. Szilády.) 183-187, 199

Leidenfrost Gyula: Oldott tápanyagok a vizi állatok táplálkozásában..(A. Pütter: Untersuchungen über die Ernährung der Wassertiere und den Stoff'haushalt des Meeres.) [Book review.] 187-194

Bolkay István: A hangyásztücsök természetrajza. Schimmer, Fritz: Beitrag zu einer Monographie der Gryllodeengattung Myrmecophila Latr. Zeitschr. für wiss. Zool., 93. Band, 1909. [Book review.] 194 


\section{9. kötet - 1910}

1. füzet:

Soós Lajos: A Planorbis corneus hím csírasejtjének szerkezetéröl. (On the structure of the Spermatozoa of Planorbis corneus.) $1-13,52-53$

Abonyi Sándor: Az Amphibia-lárvák úszóvitorlájának kifejlődéséről. (Első közlemény.) (Über die Histogenese des Flossensaumes der Amphibien-Larven.) $14-23,53$

Méhely Lajos: Ritka denevérek Budapest környékén. (Seltene Fledermaus-Arten in der Umgebung von Budapest.) 24-26, 53

Hankó Béla: A házigalamb petevezetékének szerkezete és müködése. (Bau und Funktion des Oviduktes der Haustaube.) $26-48,53$

Leidenfrost Gyula: Édesvizi halászatunk jelene.. (Süsswasserfischerei und Fischwirthschaft.) [Book review.] …………………………………………... 48-50

Szakosztályunk ülései. (Sitzungsberichte.) ……………………………………..... 50-51

2. füzet:

Abonyi Sándor: Az Amphibia-lárvák úszóvitorlájának kifejlődéséről. (Befejező közlemény.) (Über die Histogenese des Flossensaumes der Amphibien-Larven.) 55-69, 104

Bolkay István: A Molge vulgaris alakköréröl. (On the Form-group of the Molge vulgaris.) 69-88, 104-105

Abonyi Sándor: A leveleslábú rákok életmódja és a Limnadia lenticularis magyarországi elöfordulása. (Die Lebensweise der Phyllopoden und das Vorkommen von Limnadia lenticularis in Ungarn.) $88-95,105$

Hankó Béla: Branchipus és alga együttélése. (Symbiose von Branchipus und Algen.) 96-99, 105-106

Leidenfrost Gyula: A hydrobiologia kézikönyve. Steuer A.: Planktonkunde. Leipzig, 1910. [Book review.] $100-101$

Leidenfrost Gyula: Az Adria és a Földközi-tenger faunája. Cori, C. J.: Der Naturfreund am Strande der Adria und des Mittelmeergebietes. Leipzig, 1910. [Book review.] ......... 102

Szakosztályunk ülései. (Sitzungsberichte.) $102-103$

3. füzet:

Abonyi Sándor: Az Apusok és Branchipusok phototropismusáról. (Über phototropismus bei Apus und Branchipus.) $107-124,153$

Schárbert Ármin: Adatok a lepkék látószerveinek ismeretéhez. (Beiträge zur Kenntnis der Schmetterlings-Augen.) $124-137,153-154$

Rátz István: A Linguatula rhinaria előfordulása hazánkban. (Über das Vorkommen von Linguatula rhinaria in Ungarn.) $137-144,154-155$

Bolkay István: A Molge cristata subsp. Karelinii lárvájáról. (On the larva of the Molge cristata subsp. Karelinii.) 145-146, 155 
Leidenfrost Gyula: Nemes korall a Quarneroban. (On the occurance of Corallium rubrum in the Quarnero.) $146-150,155$

Leidenfrost Gyula: A kövi csík színének alkalmazkodása. (Farben-wechsel- versuche an der Bartgrundel (Nemachilus barbatula L.) [Book review.] $150-152$

Szakosztályunk ülései. (Sitzungsberichte.) 152

4. füzet:

Entz Géza, ifj.: Egy édesvizi Gymnodiniumról. (Über ein Süsswasser-Gymnodinium.) 157-163, 207-208

Abonyi Sándor: A Branchipus-peték kikelése sós vízzel való kezelésre. (Die Entwicklung der Branchipus-Eier bei Behandlung mit Salzwasser.) 163-168, 208

Szente Kornél: Adatok a rovarok zsírtestének ismeretéhez. (Beiträge zur Kenntnis des Fettkörpers der Insekten.) 169-181, 208

Szabó József: Faunánk egy új hangya-neméről. (Ein neues Ameisen-Genus unserer Fauna.) 182-184, 208

Hankó Béla: Adatok a magyarországi Planariák faunájának ismeretéhez. (Beiträge zur Kenntnis der ungarischen Planarien-Fauna.) 184-186, 209

Bolkay István: Táblázat a magyarországi békák meghatározására. (Tabellen zur Bestimmung der Frösche Ungarns.) 187-192, 209

Rátz István: Trichomonas galamb májában. (Trichomonas aus der Leber der Tauben.) 192-197, 209-210

Abonyi Sándor: A levéllábú rákok monographiája. Daday de Deés, Eug.: Monographie systématique des Phyllopodes anostracés. Annales des Sciences Naturelles, (9) t. 11. 1910. p. 91-489. [Book review.] 197-202

Leidenfrost Gyula: Biologiai képek az Adriáról. Steuer, A.: Biologisches Skizzenbuch für die Adria. Leipzig, 1910. [Book review.] 202-204

Soós Lajos: Új Mesozoa-faj. Schröder, Olaw: Buddenbrockia plumatellae, eine neue Mesozoenart aus Plumatella repens L. und Pl. fungosa Pall. Zeitschrift für wissenschaftliche Zoologie, 96. Bd., 1910. p. 525-535. [Book review.] ........... 204-205

Szakosztályunk ülései. (Sitzungsberichte.) 205-206

\section{0. kötet - 1911}

1. füzet:

Soós Lajos: A csiga-peték elsatnyulása. (On the degeneration of the egg-cells of the Gastropods.) $1-14,60$

Gróf Béla: A fekete csíkbogár (Hydrophilus piceus) női ivarkészülékének alaktana. (Morphologie des weiblichen Geschlechtsapparates von Hydrophilus piceus.) $14-26,60$ 
Szüts Andor: Adatok néhány Lumbricida anatomiájához. (Beiträge zur Anatomie einiger Lumbriciden.) 26-31, 60-61

Vutskits György: Faunánk egy új hal-fajáról. (Über eine neue Fischart der ungarischen Fauna.) $31-43,61$

Szüts Andor: Egy új plasmafestés és ezüstözés. (Eine neue Plasmafärbung und Versilberung.) $44-46,61$

Abonyi Sándor: Wesenberg-Lund plankton-elmélete. (Wesenberg-Lund's Abhandlung: Grundzüge der Biologie und Geographie des Süsswasserplanktons. Leipzig, 1910.) [Book review.] 46-55

Kertész Kálmán: A Linné-féle nomenclatura kiépítéséről. Rhumbler, L.: Über eine zweckmässige Weiterbildung der Linné-schen binären Nomenklatur. Zoologischer Anzeiger, 36. Bd., 1910, p. 453-471. [Book review.] ….................................... 55-58

Szakosztályunk ülései. (Sitzungsberichte.) $58-59$

2. füzet:

Daday Jenő: Egy új Cladocera-faj Keletindiából. (Eine neue Cladoceren-Art aus Ostindien..) $63-68,110-113$

Szombathy Kálmán: A Prosobranchiaták reczehártyájának szerkezetéről. (On the structure of the retina of the Prosobranchiata.) 68-83, 113-114

Szabó József: A Camponotus ligniperda női ivarkészülékének szerkezete. (The structure of the female genital organs of Camponotus ligniperda.) $83-96,114$

Daday Jenő: Két antarctikus ázalékállatka. (Deux Infusoires nouveaux de la région antarctique.) 97-99, 114-115

Bolkay István: Táblázat a magyarországi farkos kétéltűek meghatározására. (Tabelle zur Bestimmung der Urodelen Ungarns.) $100-101,115$

Leidenfrost Gyula: A Csendes- és az Indiai oczeán maradék fajai. Stromer, Ernst: Ueber Relikten im indopacifischen Gebiete. Centralbl. f. Miner. Geol. u. Paläontologie, 1910. [Book review.] $101-104$

Soós Lajos: Szerkezet és működés. Hesse, Richard und Doflein, Franz: Tierbau und Tierleben in ihren Zusammenhange betrachtet. I. Band. der Körper als selbständiger Organismus. Von Richard Hesse. Leipzig und Berlin, 1910. [Book review.] .... 104-105

Bolkay István: A földkerekség hüllői. Ditmars, R. L.: Reptiles of the World. London, 1910. [Book review.] $105-106$

Soós Lajos: Lamarck zoologiája. Jean Lamarck: Philosophische Zoologie. Deutsch von Heinrich Schmidt. Leipzig. [Book review.] $106-107$

Szakosztályunk ülései. (Sitzungsberichte.) 107-109

3. füzet:

Hankó Béla: Az Asellus aquaticus regeneráló tehetségéröl. (Über das Regenerationsvermögen von Asellus aquaticus.) 
Szüts Andor: A Cajal-féle ezüstözésről és az Apáthy-féle utánaranyozásról. (Über die Cajal'sche Versilberungs- und die Apáthy'sche Nachvergoldungsmethode.) $127-133,168-169$

Bolkay István: Herpetologiai megfigyelések Boszniában, Herczegovinában és déli Dalmácziában. (Contributions to the herpetology of Bosnia, Hercegovina and Southern Dalmatia.) $133-137,169$

Entz Géza, ifj.: Hydrát pusztító Amoeba. (Über eine neue Amoeben-Art. Vorläufige Mitteilung.) $138-141,169$

Entz Géza, ifj.: A gőték neoteniája. (Ein Fall von Neotenie bei Molge vulgaris.) 141-142, 169-170

Szüts Andor: Az Octolasium Frivaldszkyiról. (Über Octolasium Frivaldszkyi.) ..... 143, 170

Soós Lajos: A Protozoák és Metazoák sejtmagvának viszonyáról. Hartmann, Max: Die Konstitution der Protistenkerne und ihre Bedeutung für die Zellenlehre. Jena, 1911. [Book review.] 144-148

Leidenfrost Gyula: Időszakos változások az Adria faunájában. Steuer, A.: Veränderungen der nordadriatischen Flora und Fauna während der letzten Dezennien. Internat. Revue d. gesamt. Hydrobiol. u. Hydrographie, 3. Bd., 1910. [Book review.] $148-152$

Soós Lajos: Európa biologiai állomásai. Kofoid, Charles Atwood: The biological stations of Europe. Washington, 1910. [Book review.] $152-156$

Hankó Béla: A házi állatok boncztana. Zimmermann Ágoston: Anatomiai gyakorlatok házi állatokon. Budapest, 1911. (Anatomische Präparierübungen an Haustieren.) [Book review.] $156-157$

Csiki Ernő: A Kárpátok állatföldrajza. Holdhaus, K. und Deubel, Fr.: Untersuchungen über die Zoogeographie der Karpathen (unter besonderer Berücksichtigung der Coleopteren). Jena, 1910. [Book review.] $158-163$

Leidenfrost Gyula: Közép-Európa édesvizi halai. Vogt, C. und Hofer, Br.: Die Süsswasserfische von Mitteleuropa. Leipzig, 1909/10. [Book review.] ............. 163-166

Szakosztályunk ülései. (Sitzungsberichte.) $166-167$

4. füzet:

Abonyi Sándor: A levéllábú rákok petéinek kikeléséről. (Über die Entwicklung der Phyllopoden-Eier.) $171-176,229$

Zimmermann Ágoston: A juh episternumáról. (Über das Episternum der Schafe.) $177-182,229-230$

Grúsz Frigyes: Az amoebák mesterséges tenyésztése. (Die arteficielle Züchtung der Amoeben.) 182-193, 230

Hankó Béla: Különböző anyagok hatása az Asellus aquaticus vedlésére és regeneratiójára. (Über den Einfluss einiger Lösungen auf die Häutung und Regeneration von Asellus aquaticus.) 194-204, 230-231

Abonyi Sándor: A Limnadia lenticularisról. (Über Limnadia lenticularis.) 204-210, 231-232 
Szüts Andor: A neurofibrillák szerepe. Lenhossék, M.: Ueber die physiologische Bedeutung der Neurofibrillen. Anatomischer Anzeiger, 36. Bd., 1910. [Book review.] 210-216

Kertész Kálmán: A vérszívó legyekről. Bezzi, M.: Études systématiques sur les Muscides hématophages du genre Lyperosia. Archives de Parasitologie, t. 15., 1911. [Book review.] 217-219

Leidenfrost Gyula: A Coregonus-félék alakkörének új tagja. Thienemann, A.: Die Entstehung einer neuen Coregonenform in einem Zeitraum von 40 Jahren. Zoologischer Anzeiger, 38. Bd., 1911. [Book review.] 219-223

Hankó Béla: A kisagy szerepe. Dürken, B.: Über frühzeitige Exstirpation von Extremitätanlagen beim Frosch. Zeitschr. f. wiss. Zoologie, 99. Bd., 1911, p. 189-355. [Book review.]

224-225

Soós Lajos: Garády Gauss Viktor: A norvég rák vagy scampi (Nephrops norvegicus) és halászata különös tekintettel tengeri halászati érdekeinkre. Budapest, 1911. [Book review.] 226-227

Szakosztályunk ülései. (Sitzungsberichte.) $227-228$

\section{1. kötet - 1912}

\section{1-2. füzet:}

Abonyi Sándor: A sejt átörökítő alkotórészeiről. (Über vererbungstragende Zellsubstanzen.) $1-25,95$

Grúsz Frigyes: A lepkék illatszervei. (Die Duftapparate, der Schmetterlinge.) 26-67, 95-96 Szalay László: Kis-ázsiai Hydracarinák. (Hydracarinen aus Kleinasien.) ...... 67-81, 96-98 Szüts Andor: Új élősködő fonálféreg. (Eine neue parasitische Nematode.) ........... 81-84, 98 Leidenfrost Gyula: Új adatok az Adria faunájának ismeretéhez. [Book review.] ........ 85-90 Entz Géza: A Spirochaeták szervezetéről. ifj.: Doflein, F.: Die Natur der Spirochaeten. Jena, 1911. [Book review.] .............................................................................. 90-92

Szakosztályunk ülései. (Sitzungsberichte.) ............................................................. 92-94

3. füzet:

Soós Lajos: A Molluscák harántcsíkos izmairól. (On the striped muscles of the Molluscs.) 99-104, 157

Hankó Béla: Torzult testü tengeri csigák. (Über Missbildungen bei Nassa mutabilis.) 104-108, 157-158

Szüts Andor: A Lumbricidák dúczsejtjeiről. (Über die Ganglienzellen der Lumbriciden.) $108-116,158$

Szabó József: A Myrmecophila acervorum hímjéről. (On the male of Myrmecophila acervorum.) $116-125,158-159$

Leidenfrost Gyula: Kis-ázsiai halak. (Fishes from Asia minor.) 125-132, 159 
Leidenfrost Gyula: Az Adria Lepadogastere. (The Lepadogaster species of the Adriatic.) $132-143,159-160$

Entz Géza, ifj.: Az állatfajok száma. Pratt, H. S.: On the number of known species of animals. Science, N. S., vol. 35., 1912. [Book review.] 144-146

Soós Lajos: Az Adria új tengeri-lilioma. Clark, Austin Hobart: A new european Crinoid. Proceedings of the United States National Museum, vol. 38., Washington, 1911. [Book review.] $146-148$

Náday Lajos: Újabb tanulmányok a kerekesférgek cyklomorphosisának ismeretéhez. Dieffenbach, H. und Sachse, R.: Biologische untersuchungen an Rädertieren in Teichgewässern. Internationale Revue der gesamten Hydrobiologie und Hydrographie, 1912. [Book review.] $148-153$

Leidenfrost Gyula: Az oczeán biologiája. Richard J.: Oczeánográfia. Fordította Dr. Pécsi Albert, az eredetivel összehasonlították Dr. Kövesligethy Radó és Dr. Soós Lajos. Egy arczképpel és 344 rajzzal. Budapest, 1912. Kiadta a Kir. Magy. Természettudományi Társulat. [Book review.] $153-156$

4. füzet:

Pongrácz Sándor: Magyarország Chrysopái alak- és rendszertani tekintetben. (Die Chrysopiden Ungarns in morphologisch-systematischer Beziehung.) 161-221, 259-261

Hankó Béla: A bíborcsiga (Murex brandaris) fedőjének regeneratiójáról. (Über Regeneration des Operculums bei Murex brandaris.) ....................... 222-228, 261-262

Zimmermann Ágoston: Összehasonlító anatomiai vizsgálatok a ló elülső végtagjának ujjnyujtóiról. (Zur vergleichenden Anatomie der Zehen-strecker des Pferdes.) 229-232, 262-263

Zimmermann Ágoston: A Rauber-féle érfák. (Die Rauberschen Gefässbäume.) $233-235,263$

Entz Géza, ifj.: A mai plankton-kutatás problémái. Lohmann, H.: Die Probleme der modern Planktonforschung. Verhandlungen der Deutschen Zoologischen Gesellschaft, 1912. [Book review.] $235-252$

Soós Lajos: A Földközi-tenger kutatásának tervezete. Joubin, L.: Plan de travaux océanographique a exécuter dans les stations maritimes, adopté a Monaco par la Commission de la Méditerranée le 1-er avril 1910. Bulletin de la Société Zoologique de France, T. XXXV.. [Book review.] $252-256$

Szakosztályunk ülései. (Sitzungsberichte.) $256-258$

\section{2. kötet - 1913}

1. füzet:

Szüts Andor: Az Archaeo- és Neolumbricidák. (Die Archaeo- und Neolumbriciden.) $1-14,55$

Soós Lajos: A Pleurotomaria-nem. (Über die Gattung Pleurotomaria.) $14-21,55$ 
Szombathy Kálmán: Adatok a hangyautánzó ugrópókok pontosabb ismeretéhez. (Contributions pour l'éiude des Salticides formiciformes.) $22-40,55-57$

Soós Lajos: A rovarok heterochromosomái. Gross, J.: Heterochromosomen und Geschlechtsbestimmung bei Insecten. Zoologische Jahrbücher, Abt. für allgemeine Zoologie, 32. Bd., 1912. [Book review.] $40-44$

Szüts Andor: Planktonikus életmód, kisagyvelő és helyváltoztatás. Franz, V.: Über das Kleinhirn und die statische Funktion bei den planktonischen Fischlarven. Verhandl. d. VIII. Internat. Zoologen-Kongress zu Graz, 1910. Jena, 1912.; Franz, V.: Über das Kleinhirn inder vergleichenden Anatomie. Biologisches Centralblatt, 31. Band, 1911. [Book review.] 44-46

Hankó Béla: Hallanak-e a rovarok? Peter, K.: Versuche über das Hörvermögen eines Schmetterlings. Biol. Centralbl., 32. Band., 1912. [Book review.] ....................... 46-47

Hankó Béla: Az ondósejtek elterjedése és szerepe a női testben. Kohlbrugge, J. H. F.: Die Verbreitung der Spermatozoiden im weiblichen Körper und im befruchteten Ei. Arch. f. Entwicklungsmech., 35. Bd., 1912. [Book review.] $48-49$

Hankó Béla: A csillangós ázalékállatkák visszaszerző tehetségéről. Ishikawa, Hidetsurumaru: Wundheilungs- und Regenerationsvorgänge bei Infusorien. Arch. f. Entwicklungsmech., 35. Bd., 1912. [Book review.] 49-50

Hankó Béla: A fejlődésmechanika első szótára. Roux, W.: Terminologie der Entwicklungsmechanik der Tiere und Pflanzen. Leipzig, 1912. [Book review.] ... 50-51

Szakosztályunk ülései. (Sitzungsberichte.) $51-54$

2. füzet:

Méhely Lajos: A zoologiai kutatás nemzeti feladata. (Die nationale Aufgabe der zoologischen Forschung.) 59-64, 128-129

Méhely Lajos: Az emlősök faji criteriuma. (Das Artcriterium der Säugetiere.) 65-72, 129-130

Kottász József: Budapest környékének Cladocerái. (Die Cladoceren der Umgebung von Budapest.) 73-104, 130

Szüts Andor: A Quarnero egy érdekes rákja. (Über einen interessanten Krebs aus dem Quarnero.) 104-108, 131

Zimmermann Ágoston: A ló szarugesztenyéi. (Über die Kastanien des Pferdes.) $108-117,131-132$

Abonyi Sándor: Megjegyzések Graeter Eduard „Chirocephalus (Tanymastyx) stagnalis Linné im südlichen Schwarzwald" cz. közleményéhez. (Bemerkungen zu Eduard Graeter's Abhandlung „Chyrocephalus (Tanymastyx) stagnalis L. im südlichen Schwarzwald".) 117-120, 132

Gaál István: Az ősélettan alapvonalai. Abel, O.: Grundzüge der Palaeobiologie der Wirbeltiere. Stuttgart, 1912. [Book review.] $120-124$

Zimmermann Ágoston: A sertés fejartériái. Diwó A. és Roth J.: A sertés fejartériáinak öszszehasonlító anatomiája. Közlemények az összehasonlító élet- és kórtan köréböl, IX. kötet, 6-8. füzet. [Book review.] 125-126 
3. füzet:

Méhely Lajos: Magyarország mérges siklói. (Die Giftnattern Ungarns.) $133-138,190$

Jungmayer Mihály: Adatok Bosznia Copepoda-faunájának ismeretéhez. (Beiträge zur Copepoden-Fauna Bosniens.) 138-147, 190-191

Hankó Béla: Villáskarú Octopus. (Über den gespaltenen Arm eines Octopus vulgaris.) $147-151,191$

Soós Lajos: A magyar fauna-terület Pomatiasai. (Első közlemény.) (Die Pomatias-Arten des ungarischen Faunen-gebietes.) $151-224,191$

Soós Lajos: Dr. Méhely Lajos: Magyarország csíkos egerei. Mathematikai és Természettudományi Közlemények, 32. kötet, 1913, 1. sz.. (Über die Sicistinen Ungarns) [Book review.] 179-181

Szüts Andor: Dr. Gelei József: Tanulmányok a Dendrocoelum lacteum Oersted szövettanáról. Budapest, (1909)-1912. (Histologische Studien über Dendrocoelum lacteum) [Book review.] 81-185

Abonyi Sándor: A bogarak Malpighi-edényei. Dr. Gorka Sándor: Anatomiai és élettani adatok a bogarak Malpighi-edényei működésének megitéléséhez. Budapest, 1913. (Anatomische und physiologische Beiträge zur Beurteilung der Funktion der Malphighischen Gefässe von Käfern) [Book review.] ..................................... 186-187

Szakosztályunk ülései. (Comptes rendus des séances de notre section.) $187-189$

4. füzet:

Soós Lajos: A magyar fauna-terület Pomatiasai. (Második közlemény.) (Die PomatiasArten des ungarischen Faunengebietes.)

Szombathy Kálmán: A pókok ivarhólyagjának szerkezete és müködése. (Bau und Funktion des bulbus genitalis der Spinnen.) 224-243, 262-263

Zimmermann Ágoston: Száraz agyvelőkészítmények előállításáról. (Über Herstellung von trockenen Gehirnpräparaten) 243-247, 263-264

Kertész Kálmán: A legyek és a betegségek. Graham-Smith, G. S.: Flies in Relation to Disease. Nonbloodsucking Flies. Cambridge, 1913. XIV, 292 lap, 24 tábla és 32 rajz. [Book review.] 247-249

Zimmermann Ágoston: Adatok az epevezeték és pankreasvezetékek összehasonlító anatomiájához. Baumann, S. u. Schmotzer, B.: Beiträge zur vergleichenden Anatomie des Vater'schen Divertikels und der Mündung der Gallen- und Pankreasgänge. Österreichische Wochenschrift für Tierheilkunde, 1912, Nr. 47-51. [Book review.] $250-251$

Soós Lajos: Az oceanographia legújabb kézikönyve. Murray, Sir John, and Hjort, Johan: The Depths of the Ocean. London, 1912. [Book review.] $251-253$

Hankó Béla: A lepkék lárvaszerveinek regeneratiója. Kopeć, St.: Untersuchungen über die Regeneration von Larvalorganen und Imaginalscheiben bei Schmetterlingen. Arch. f. Entwicklungsmech., 37. Bd., 1913. [Book review.] 253-254 
Hankó Béla: A táplálkozás befolyása a békalárvák regeneratiójára. Romeis, B.: Der Einfluss verschiedenartiger Ernährung auf die regeneration bei Kaulquappen (Rana esculenta). Arch. f. Entwicklungsmech., 37. Bd., 1913. [Book review.] ............ 254-255

Hankó Béla: A Hydroideák gonophorjának regeneratioja. Müller, H. C.: Die Regeneration der Gonophore bei den Hydroiden und anschliessende biologische Beobachtungen I. Athecata. Arch. f. Entwicklungsmech., 37. Bd., 1913. [Book review.] $255-256$

Soós Lajos: A Bartholomew-féle állatföldrajzi atlasz. Bartholomew, J. G., W. Eagle Clarke and Percy A. Grimshaw: Atlas of Zoogeography. (Bartholomew's Physical Atlas, volume V.) Edinburgh, 1911. [Book review.] 256-257

Soós Lajos: Gyakorlati oceanographia. Fowler, G. H.: Science of the Sea. An elementary handbook of practical oceanography. Prepared by the Challenger Society, edited by G. H. Fowler. London, 1912. [Book review.] $257-258$

Szakosztályunk ülései. (Comptes rendus des séances de notre section.) $258-259$

\section{3. kötet - 1914}

1. füzet:

Méhely Lajos: Egy pillantás a fajformálódás műhelyébe. (Ein Blick in die Werkstätte der Artbildung.) $1-10,74-76$

Szüts Andor: Adatok az idegrendszer és a megújulás összefüggéseinek ismeretéhez. (Über die Abhängigkeit der Regeneration vom Zentralnervensystem.) .............. 10-20, 76-77

Jungmayer Mihály: Adatok Makó Copepoda-faunájának ismeretéhez. (Über die Copepoden-Fauna der Stadt Makó.) 20-29, 77

Vutskits György: Az Al-Duna halfaunájáról. (Über die Fischfauna der unteren Donau.) 29-45, 77-78

Kieselbach Gyula: A légylárvák bőrérzékszerveiről. (Die Hautsinnesorgane der MuscidenLarven.) 45-57, 78-79

Soós Lajos: Murray, Sir John, and Johan Hjort: Report on the Scientific Results of the "Michael Sars" North Atlantic Deep Sea Expedition 1910. Vol. III., Part 1., Zoology. Bergen (1913). [Book review.] $57-61$

Pell Mariska: Brunelli, G.: Ricerche etologiche. Osservazioni ed esperienze sulla simbiosi dei Paguridi e delle Attinie. Zool. Jahrb., Abt. f. allg. Zool. u. Phys., 34. Bd., 1913. [Book review.] 61-62

Hankó Béla: Ceni, C.: Spermatogenesi aberrante consecutiva a commozione cerebrale. Arch. f. Entwicklungsmech., 38. Bd., 1913. [Book review.] 62-63

Hankó Béla: Aschner, Bernhard: Über die Funktion der Hypophyse. Arch. f. d. ges. Physiol., 146. Bd., 1913. [Book review.]

Szüts Andor: Dammerman, K. W.: Der saccus vasculosus der Fische ein Tiefeorgan. Zeitschr. wiss. Zool., 96. Bd., 1910.; Franz, W.: Beitrag zur Kenntnis des Ependyms im Fischgehirn. Biologisches Centralblatt, 32. Bd., 1912. [Book review.] 63-65 
Pell Mariska: Moore, A. R.: Further Experiments in the Heterogeneous Hybridization of Echinoderms. Arch. f. Entwicklungsmech., 37. Bd., 1913. [Book review.] $65-66$

Hankó Béla: Boeke, J.: Über die Regenerationserscheinungen bei der Verheilung von motorischen mit sensiblen Nervenfasern. Anat. Anz., 43. Bd., 1913. [Book review.] . 66

Hankó Béla: Krizenecky, J.: Über Restitutionserscheinungen an Stelle von Augen bei tenebrio-Larven nach Zerstörung der optischen Ganglien. Arch. f. Entwicklungsmech., 37. Bd., 1913. [Book review.] 66-67

Soós Lajos: Rossmässler's Iconographie der europäischen Land- und SüsswasserMollusken. Fortgesetzt von W. Kobelt. Neue Folge, 21. Bd., Die Familie der Clausiliidae, ergänzt von A. J. Wagner. Wiesbaden, 1913. [Book review.] 67-69

Soós Lajos: Wester, D. H.: Chemischer Beitrag zur Limulus-Frage. Zoolog. Jahrb. Syst., 35. Bd., 1913.; Schliesst sich Peripatus capensis chemisch den Anneliden oder den Arthropoden? U. o.. [Book review.]

Szombathy Kálmán: Dahl, Friedrich: Vergleichende Physiologie und Morphologie der Spinnenthiere unter besonderer Berücksichtigung der Lebensweise. Erster teil. Die Beziehungen des Körperbaues und der Farben zur Umgebung. Jena, 1913. [Book review.] $70-71$

Szakosztályunk ülései. (Comptes rendus des séances de notre section.) $71-73$

2. füzet:

Méhely Lajos: A magyar mammalogia mai állása. (Der heutige Stand der ungarischen Mammalogie.) $81-93,149$

Szabó József: Magyarország rabszolgatartó és élősködő hangyái. (Ungarns sklavenhaltende und parasitische Ameisen.) 93-105, 149-150

Szüts Andor: Új haematoxylin-festés. (Eine neue Hämatoxylin-Färbung.) ..... 106-107, 150

Csengő Nándor: A csuka fejvázáról. (Über das Kopfskelet von Esox lucius.) 107-127, 150

Lendvai János: Az élő sejt protoplasmája a fluorescentiás mikroszkóp alatt. (Das Protoplasma der lebendigen Zellen unter dem Reichert'schen Fluoreszenzmikroskop.) 127-130, 150-151

Kormos Tivadar: Méhely Lajos: Fibrinae Hungariae. Magyarország harmad- és negyedkori gyökeresfogú poczkai, különös tekintettel a fajformálódás tényezőire és időszakaira. (1102 lapon, nyolcz táblával és egy szövegközti rajzzal). A Magyar Tudományos Akadémia mathematikai és természettudományi bizottságának kiadása. Budapest, 1914. (Fibrinae Hungariae. Die tertiären und quartären wurzelzähnigen Wühlmäuse Ungarns, mit besonderer Berücksichtigung der Faktoren und Zeitalter der Artbildung) ... 131-136

Szabó József: Zander, E.: Das Geruchsvermögen der Bienen. Biol. Centralblatt, 33. Bd., 1913. [Book review.] $136-137$

Hankó Béla: Schiller, J.: Über somatische Induktionen auf die Keimdrüsen bei den Säugetieren. Arch. f. Entwicklungsmech., 38. Bd., 1913. [Book review.] ......... 137-138

Hankó Béla: Fraenkel, M.: Röntgenstralhenversuche an tierischen Ovarien. Arch. f. mikr. Anat., 84. Bd., 1914. [Book review.] 138 
Szüts Andor: Bethe, Albrecht: Können intracelluläre Strukturen bestimmend für die Zellgestalt sein? Anatomischer Anzeiger, 44. Bd., 1913. [Book review.] 139-140

Szüts Andor: Waelsch, Ludwig: Über experimentelle Erzeugung von Epithelwucherungen und Vervielfachungen des Medullarrohres ("Polymyelie") bei Hühnerembryonen. Arch. f. Entwmech. d. Org., 38. Bd., 1914. [Book review.] 140-141

Szüts Andor: Delsmann, H. C.: Ist das Hirnbläschen des Amphioxus dem Gehirn der Kranioten homolog? Anat. Anz., 44. Bd., 1913. [Book review.] 141

Soós Lajos: Mollusques de la France et des régions voisines. Tome I. Vayssiere, A.: Amphineures, Gastéropodes Opisthobranches, Hétéropodes, Marséniadés et Oncidiidés. Paris, 1913. Tome II. Germain, L.: Gastéropodes Pulmonés et Prosobranches terrestres et fluviatiles. Paris, 1913. [Book review.] $142-143$

Soós Lajos: Moser, F.: Über eine festsitzende Ctenophore und eine rückgebildete Siphonophore. Sitzungsberichte der Gesellschaft Naturforschender freunde, Jahrg. 1912. [Book review.] 143-144

Soós Lajos: Ekman, S.: Studien über die marinen Relikte der nordeuropäischen Binnengewässer. II. Die Variation der Kopfform bei Limnocalanus Grimaldii (de Guerne) und L. macrurus G. O. Sars. Internat. Revue der gesamten Hydrobiologie und Hydrographie, 6. Bd., 1913. [Book review.] 144-146

Szakosztályunk ülései. (Comptes rendus des séances de notre section.) $146-148$

3-4. füzet:

Méhely Lajos: A legkisebb emlős állat Magyarországon. (Das kleinste Säugetier in Ungarn.) 153-161, 221

Náday Lajos: A Balaton planktonikus kerekesféreg-faunája. (Die Rotatorienfauna des Balaton-Sees.) $161-169,221-222$

Zimmermann Ágoston: A patás állatok ínhüvelyeiről és nyálkatüszőiről. (Über die Sehnenscheiden und Schleimbentel der Huftiere.) $169-176,222$

Greschik Jenő: A kárász bélcsatornája, különös tekintettel a rugalmas rostokra. (Der Darmkanal der Karausche, mit besonderer Berücksichtigung der elastischen Fasern.) 177-184, 222-223

Bittera Gyula: Az egérfélék hím párzószervének rendszertani jelentősége. (Die systematische Bedeutung der männlichen Kopulationsorgane der Muriden.) 184-201, 223

Fényes Dezső: Az európai csóka. (Die europäische Dohle.) 201-205, 223-224

Leidenfrost Gyula: Car, L., Hadzi, J.: Biologijska Opazanja. Izvestaji o. 1.I.2. Naucnom istrazivanju Jadranskoga Mora God. 1913. Prir. Istrazivanju Hrvatske i Slavonije potaknuta mat. prir. razr. Jugosl. Akad. Zagreb, 1914. (12 táblázattal); Car, L., Hadzi, J.: Biologische Beobachtungen. Izvjeska o raspravama mat. prir. razr. Zagreb, 1914. [Book review.] 205-208

Szabó-Patay József: Klodnitzki, J.: Beiträge zur Kenntnis des Generationswechsels bei einigen Aphididae. Zool. Jahrb. Abt. f. Syst. etc. d. Tiere, 33. Bd., 1912. [Book review.] 
Kertész Kálmán: Escherich, K.: Die Forstinsekten Mitteleuropas. Ein Lehr- und Handbuch. Als Neuauflage von Judeich-Nitsche, Lehrbuch der mitteleuropäischen Forstinsektenkunde bearbeitet. Erster Band. Allgemeiner Teil. Einführung in den Bau und lebensweise der Insekten,sowie in die allgemeinen Grundsätze der praktischen Forstentomologie. Berlin, 1914. 432 lap, 248 ábra. [Book review.] 211

Kertész Kálmán: Zeitschrift für angewandte Entomologie. Zugleich Organ der Deutschen Gesellschaft für angewandte Entomologie. Herausgegeben von Dr. K. Escherich und Dr. F. Schwangart. [Book review.]

Soós Lajos: Künkel, K.: Ein bisher unbekannter, grundlegender Faktor für die Auffindung eines Vererbungsgesetzes bei den Nacktschnecken. Verh. d. Ges. Deutsch. Naturf. und Ärtzte, 82. Vers. Leipzig, 1912.; Baltzer, F.. Über die Chromosomen der Tachea (Helix) hortensis, Tachea austriaca und der sogenannten einseitigen Bastarde T. hortensis $x T$. austriaca. Arch. f. Zellforschung, 11. Bd., 1913. [Book review.] $212-213$

Soós Lajos: Rossmässler's Iconographie der europäischen Land- und SüsswasserMollusken. Fortgesetzt von W. Kobelt. Neue Folge, 21. Bd., Die Familie der Clausiliidae, ergänzt von A. J. Wagner. Wiesbaden, 1914. [Book review.] 214-216

Soós Lajos: Kimakowicz-Winnicki, M.: Clausilium. Eine morphologisch-physiologische Studie. Zool. Jahrb. Abt. f. Syst., 37. Bd., 1914. [Book review.] 216

Greschik Jenő: Vitali, G.: Di un nuovo organo nervoso di senso nell'orecchio medio degli uccelli. Ulteriore destino dell'organo della prima fessina branchiale. Internat. Monatsschr. f. Anat. u. Physiol., 30. Bd., 1914. [Book review.] 217

Soós Lajos: May, W.: Grosse Biologen. Leipzig und Berlin, 1914. [Book review.] 217-218

Szakosztályunk ülései. (Comptes rendus des séances de notre section.) $218-220$

\section{4. kötet - 1915}

1. füzet:

Horváth Géza: A törpe egér magyarországi alakjának tudományos neve. (Zur Nomenclatur der Zwergmaus.) $1-5,77$

Szüts Andor: Az Adria egy érdekes és két eddig ismeretlen tízlábú rákja. (A Magyar Adria Egyesület kutatási eredményeiből.) (Neue und interessante Decapodenkrebse aus der Adria.) $5-15,77$ 
Szüts Andor: Az Adria planktonja és a Magyar Adria Egyesület kutatásai a "Najade" hadihajón. (Das Plankton der Adria und die Forschungen des Ungarischen Adria-Vereins auf der Adria.) $15-47,78$

Pongrácz Sándor: A Blattidák szervezetének rendszertani jelentősége. (Die systematische Bedeutung der Blattiden.) $48-63,78-80$

Soós Lajos: Sturany, R. und Wagner, A. J.: Über schalentragende Landmollusken aus Albanien und Nachbargebieten. Denkschr. Akad. Wien, 91. Bd., 1914. [Book review.] 63-66

Szombathy Kálmán: Lang, Arnold: Handbuch der Morphologie der wirbellosen Tiere. IV. Band. Arthropoda. Daiber, Marie: Merostomata, Arachnoidea. Jena, 1913. [Book review.] $66-68$

Leidenfrost Gyula: Grassi, Battista: Metamorfosi dei Murenoidi. Ricerche sistematiche ed ecologiche - Metamorphose der Muraenoiden. Systematische und ökologische Untersuchungen. Jena, 1913. [Book review.] $68-70$

Soós Lajos: Wagner, A.: Höhlenschnecken aus Süddalmatien und der Hercegovina. Sitzungsber. Akad. Wien, 123. Bd., 1. Abt., 1914. [Book review.] 70-71

Soós Lajos: Kalkschmid, J.: Die Heteropteren der "Najade"-Expeditionen. Sitzungsber. Akad. Wien, 122 Bd., 8. Heft, 1913. [Book review.] $71-72$

Szabó-Patay József: Frisch, K.: Der Farbensinn und Formensinn der Biene. Zool. Jahrb., Allg. Zool., 35. Bd., 1914. [Book review.] $72-74$

Szabó-Patay József: Kranichfeld, H.: Zum Farbensinn der Bienen. Biol. Centralblatt, 35. Bd., 1915. [Book review.] $74-75$

Szakosztályunk ülései. (Comptes rendus des séances de notre section.) $75-76$

2-3. füzet:

Kertész Kálmán: A Magyar Birodalom Sciomyzidái. (Die Sciomyziden Ungarns.) $81-126,193$

Szombathy Kálmán: A pókok potrohának izomrendszeréről. (Előzetes közlemény.) (Über die Muskulatur des Abdomens der Spinnen. Vorläufige Mitteilung.) 126-147, 193-194

Soós Lajos: A Nagy-Alföld Mollusca-faunájáról. (Über die Molluskenfauna der Ungarischen Tiefebene.) 147-173, 194-195

Pongrácz Sándor: Jacobi, A.: Mimikry und verwandte Erscheinungen. Braunschweig, 1913. [Book review.] 173-183

Pongrácz Sándor: Kühne, O.: Der Tracheenverlauf im Flügel der Koleopterennymphe. Zeitschr. wiss. Zool., 112. Bd., 1915. [Book review.] $183-185$

Soós Lajos: Mayer, P.: Einführung in die Mikroskopie. Berlin, 1914. [Book review.] $185-186$

Rátz István: The Journal of Parasitology, a quarterly devoted to Medical Zoology. Volume I. Number 1-3. Managing Editor Henry B. Ward, the University of Illinois, Urbana. [Book review.] 186-188 
Szabó-Patay József: Natzmer, G.: Das biogenetische Grundgesetz im Leben der Insekenstaaten. Biol. Centralblatt, 35. Bd., 1915. [Book review.] 188-189

Soós Lajos: Wagner, A. J.: Beiträge zur Anatomie und Systematik der Stylomatophoren aus dem Gebiete der Monarchie und der angrenzenden Balkanländer. Denkschr. Akad. Wien, 91. Bd., 1915. [Book review.] 189-190

Szakosztályunk ülései. (Comptes rendus des séances de notre section.) 190-192

4. füzet:

Vutskits György: A kősüllő faji bélyegei és a fogassüllő ivari kétalakúsága. (Über die Altmerkmale von Lucioperca volgensis und den Sexualdimorphismus von Lucioperca sandra.) 197-207, 274

Greschik Jenő: A levéldarázs-lárvák középbelének hámja; a mag szerepe a hólyagalakú secretióban. (Das Mitteldarmepithel der Tenthrediniden-Larven; die Beteiligung des Kerns an der blasenförmigen Sekretion.) 207-225, 274-275

Zimmermann Ágoston: A ló és a marha paranasalis sinusai. (Über die Nebenhöhlen der Nase des Pferdes und des Rindes.) 226-240, 275-276

Babic István: Az Adria Thenea-fajáról. (A Magyar Adria Egyesület kutatásainak eredményeiböl.) (Über die adriatische Thenea-Form.) 240-243, 276-277

Kormos Tivadar: Fossilis csontokon észlelhető kóros elváltozásokról. (Über krankhafte Veränderungen an fossilen Knochen.) 244-262, 277-278

Schréter Zoltán: Két reliktum csigafaj új termőhelyei hazánkban. (Neue Fundorte zweier relikten Gastropoden-Arten aus Ungarn.) $262-265,279$

Greschik Jenő: Rohde, E.: Zelle und Gewebe im neuen Licht. Vorträge und Aufsätze über Entwicklungsmechanik der Organismen. Heft XX. 1914. [Book review.] 265-267

Greschik Jenő: Van Wijhe, J. W.: Studien über Amphioxus. I. Mund und Darmkanal während der Metamorphose. Verhandelingen der Koninklijke Akad. van Wetenschappen te Amsterdam. (Tweede Secte). Deel XVIII. No. 1. 1914. [Book review.] 267-268

Szabó-Patay József: Wasmann, E.: Neue Beiträge zur Biologie von Lomechusa und Atemeles, mit kritischen Bemerkungen über das echte Gastverhältnis. Zeitschr. für wiss. Zoologie, 114. Bd., 1915. [Book review.] 268-269

Rátz István: Neumann, R. O. und Mayer, M.: Atlas und Lehrbuch wichtiger tierischer Parasiten und Überträger mit besonderer Berücksichtigung der Tropenpathologie. Mit 300 farbigen Abbildungen auf 45 lithographischen Tafeln und 237 schwarzen Textfiguren. München, 1914. [Book review.] 269-271

Szakosztályunk ülései. (Comptes rendus des séances de notre section.) $271-273$

\section{5. kötet - 1916 \\ Ünnepi füzet az Állattani Szakosztály 25 éves fennállásának emlékére}

1-2. füzet: 
Méhely Lajos: A zoologia helye tudásunk rendszerében. (Die Zoologie im System unseres Wissens.) $1-31,195-196$

Soós Lajos: Visszapillantás az Állattani Szakosztály eddigi működésére. (Rückblick auf die bisherige Tätigkeit der Zoologischen Sektion.) 31-43, 196

Csiki Ernő: Az Állattani Szakosztály huszonötéves multja. (Aus der 25jährigen Geschichte der Zoologischen Sektion.) 43-47, 196-197

Entz Géza, id.: A biologia fogalma. (Der Begriff der Biologie.)

47-64, 197-198

Entz Géza, ifj.: A véglények színéröl. (Über Färbung der Protisten.)

65-95, 198-200

Greschik Jenő: Boveri Tivadar. (Theodor Boveri.)

95-103, 200-201

Horváth Géza: Adalék a nagyváradi Püspökfürdő faunájához. (Beitrag zur Fauna der Thermen von Grosswardein.) 103-107, 201

Kertész Kálmán: A Pachygastrinák nemeinek származástani kapcsolata. (Phylctiseher Verband der Pachygastrinen-Gattungen.) 107-119, 201-202

Pongrácz Sándor: A rovarok faji criteriuma. (Das Artkriterium der Insekten.)

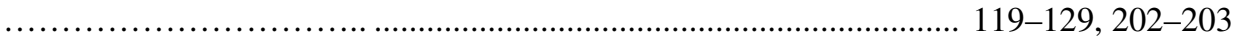

Rátz István: Új Sparganum-faj. (Eine neue Sparganum-Art.) 129-135, 203-204

Soós Lajos: A magyarországi Neritinák ivarkészülékéről. (Über den Geschlechtsapparat der ungarischen Neritinen.) $135-157,204$

Szabó-Patay József: Adatok a hangyásztücsök életmódjának ismeretéhez. (Beiträge zur Kenntnis der Lebensweise der Ameisengrille.) 157-162, 204-205

Vutskits György: A magyar halászat és ichthyologia története az utolsó 25 év alatt. (Über die Fortschritte der ungarische Ichthyologie während der letzten 25 Jahre.) 162-174, 205

Zimmermann Ágoston: A teve gyomrának úgynevezett víztartói. (Die Wassersäcke des Magens der Kameliden.) $174-180,205$

Leidenfrost Gyula: Az Adria mélytengeri halai. (Előzetes jelentés a Magyar Tengerkutató Bizottságnak az Adria déli medenczéjében végzett gyüjtéseiről.) (Die Tiefseefische der Adria.) 180-194, 205-206

3-4. füzet:

Buczkó Emil József: A pókok szövőszemölcseiről. (Über die Spinnwarzen der Aranaeen.) 207-231, 339

Jablonowski József: Egy délszaki paizstetű hazánkban. ( Eine tropische Aphide in Ungarn.) 232-247, 339

Wellmann Oszkár: Keresztezési kísérletek simaszőrü feketebarna tacskóval és simaszőrü foxterrier kutyával. (Kreuzungsversuche mit kurzhaarigem, schwarzbraunem Dachshund und kurzhaarigem Foxterrier.) 248-262, 339-340

Unger Emil: Adatok a Duna faunájának és oekologiájának ismeretéhez. (Beiträge zur Kenntnis der Fauna und Ökologie der Donau auf der Strecke Nagymaros-Ercsi.) $262-281,340$ 
Gorka Sándor: A hazai édesvízi kagylók kopoltyújának és szájvitorlájának szerepe a táplálkozásban. (Über die Rolle der Kiemen und Mundlappen der heimischen Süsswassermuscheln bei der Ernährung.) ...................................... 281-318, 340-341

Soós Lajos: Kormos Tivadar és Lambrecht Kálmán: A pilisszántói kőfülke. A Magyar Kir. Földtani Intézet Évkönyve, 23. kötet, 1915. (Die Felsnische Pilisszántó.) [Book review.] $318-320$

Greschik Jenő: Maurer, F.: Grundzüge der vergleichenden Gewebelehre. Leipzig, 1915. [Book review.] 320-323

Greschik Jenő: Buchner, P.: Praktikum der Zellenlehre. I. Teil. Allgemeine Zellen- und Befruchtungslehre. Sammlung Naturwissenschaftlicher Praktika. Band V. Berlin, 1915. [Book review.] 323-324

Greschik Jenő: Schaxel, J.: Die Leistungen der Zellen bei der Entwicklung der Metazoen. Jena, 1915. [Book review.] 325-326

Greschik Jenő: Abderhalden, E.: Neuere Anschauungen über den Bau und den Stoffwechsel der Zelle. 2. Aufl. Berlin, 1916. [Book review.] 326-327

Kertész Kálmán: Erhardt, Elisabeth: Zur Kenntnis der Innervierung und der Sinnesorgane der Flügel von Insecten. Zoolog. Jahrbücher, Abt. f. Anat. u. Ontog., 39. Bd., 1916. [Book review.] 327-329

Szakosztályunk ülései. (Comptes rendus des séances de notre section.) 329-338

\section{6. kötet - 1917}

\section{1-2. füzet:}

Dr. Rátz István †. [In memoriam Dr. István Rátz.] 1

Horváth Géza: Bizonyos állatfajok szigetszerü előfordulásának magyarázata. (Über das sporadische Vorkommen gewisser Tierarten.) 2-9, 140

Leidenfrost Gyula: Halak és tüskésbőrűek az Adriából. (II-ik előzetes jelentés a Magyar Tengerkutató Bizottságnak Őfelsége "Najade" hajójával végzett állattani gyüjtéseiről.) (Fische und Stachelhäuter aus der Adria.) 9-55, 140-141

Jablonowski József: A rakotthátú paizstetüröl és hazai előfordulásáról. (Über das Vorkommen des Eucalymnatus tessellatus (So.) in Ungarn.) 55-73, 141-142

Greschik Jenő: Az Ablepharus pannonicus és az Anguis fragilis bélcsatornájáról. (Über den Darmkanal von Ablepharus pannoniens und Anguis fragilis.) 73-82, 142

Zimmermann Ágoston: Mirigyek a patában. (Die Drüsen im Hufe des Pferdes.) 82-85, 142-143

Krepuska Gyula: Budapest véglényei. (Első közlemény.) (Die Protisten von Budapest.) 86-116, 143

Kertész Kálmán: A legyek rezgetyüiről. (Über die Halteren der Dipteren. Zusammenfassendes Referat.) 116-124 
Entz Géza: Jollos, V.: Die Fortpflanzung der Infusorien und die potentielle Unsterblichkeit der Einzelligen. Biologisches Centralblatt, 36. Bd., 1916. [Book review.] 124-127

Entz Géza: Doflein, Fr.: Studien zur Naturgeschichte der Protozoen. VII. Zoologische Jahrbücher, Abteilung für Anatomie und Ontogenie der Tiere, 39. Bd., 1916. [Book review.] $127-128$

Entz Géza: Doflein, Fr.: Zuckerflagellaten. Untersuchungen über den Stoffwechsel farbloser Masligophoren. Biologisches Centralbl., 36. Bd., 1916. [Book review.] 128-129

Greschik Jenő: Held, H.: Untersuchungen über den Vorgang der Befruchtung. I. Der Anteil des Protoplasmas an der Befruchtung von Ascaris megalocephala. Arch. f. mikroskop. Anat., 89. Bd., 1916. [Book review.] 129-131

Greschik Jenő: Schreiner, K. E.: Zur Kenntnis der Zellgranula. Untersuchungen über den feineren Bau der Haut von Myxine glutinosa. Arch. f. mikroskop. Anat., 89. Bd., 1916. [Book review.] 131-133

Greschik Jenő: Gross, R.: Beobachtungen und Versuche an lebenden Zellkernen. Arch. f. Zellforschung, 14. Bd., 1916. [Book review.] 133-134

Greschik Jenő: Adler, L.: Untersuchungen über die Entstehung der Amphibienneotenie. Zugleich ein Beitrag zur Physiologie der Amphibienschilddrüse. Pflüger's Arch. f. d. ges. Physiol., 164. Bd., 1916. [Book review.] 134-135

Szakosztályunk ülései. (Comptes rendus des séances de notre section.) $136-139$

3. füzet:

Zimmermann Ágoston: Rátz István emlékezete. (Stefan v. Rátz. (Nachruf).).. 145-154, 222

Krepuska Gyula: Budapest véglényei. (Befejező közlemény.) (Die Protisten von Budapest.) 154-184, 222

Zsámár György: A házinyúl heréje és ondóvezetője. (Die Hode und der Samenleiter des Kaninchens.) 184-211, 223-224

Szilády Zoltán: Kihalt nagy emlőseink. (Dr. Szalay Béla állattörténeti tanulmányai.) (Der tiergeschichtlichen Studien von dr. Béla Szalay.) [Book review.] $211-221$

4. füzet:

Entz Géza: Visszapillantás a magyar állattannak félszázad előtti állapotára. (Rückblick auf den Stand der Zoologie in Ungarn vor fünfzig Jahren.) 225-232, 273

Nagy Jenő: Magyarország avigeographiai felosztása és jellemzése. (Die avigeographische Einteilung und Charakterisierung Ungarns.) 232-260, 273-276

Kertész Kálmán: Howard, L. O. [Book review.]Fordította Jablonowski József, az eredetivel összehasonlította id. Entz Géza. A Kir. Magy. Természettudományi Társulat Könyvkiadó Vállalatának XCI. kötete. XV és 232 lap, a szövegben és 15 külön táblán 40 képpel. Budapest, 1917. (Die Hausfliege) [Book review.] 260

Soós Lajos: Zimmermann Ágoston: Fejlődéstan. 311 szövegközti képpel. Állatorvosi kézikönyvtár, XXI. kötet. Budapest, 1917. (Entwicklungsgeschichte) [Book review.] $261-262$ 
Szombathy Kálmán: Lendl Adolf: A pókok izomrendszere. 1. A typikus izomrost szövettani szerkezete. (9 táblával és 33 szövegrajzzal). Mathematikai és Természettudományi Közlemények, 34. köt., 1. sz., 1917. (Das Muskelsystem der Spinnen. I. Der histologische Bau der typischen Muskelfaser) [Book review.] .......................... 262-264

Szakosztályunk ülései. (Comptes rendus des séances de notre section.) .................. 264-272

\section{7. kötet - 1918}

\section{1-2. füzet:}

Zimmermann Ágoston: A patás állatok ízületi felületeinek synoviális gödrei. (Die Synovialgruben der Ungulatengelenke.) $1-10,92$

Entz Géza: A véglények magszerkezetéről és chromatin-reductiójáról. (Első közlemény.) (Über Kernbau und Chromatin-Reduction der Protisten. (1. Mitteilung.) $10-22,92$

Pell Mária: Az I. és II. magyar Adria-expeditio Hydromedusái. (Előzetes közlemény.) (Die Hydromedusen der I. und II. ungarischen Adria Expedition. (Vorläufige Mitteilung.) 22-32, 92-93

Fejérváryné Lángh Aranka Mária: A békák csökevényes bordáiról. (Über die rudimentären Rippen der anurer Batrachier.) $33-43,93$

Szüts Andor: Adatok Horvát- és Bosnyákország Lumbricidáinak ismeretéhez. (Beiträge zur Kenntnis der Lumbriciden von Kroatien und Bosnien.) 43-48, 93-94

Szabó-Patay József: Az Aphelochirus lélekzőkészülékének szerkezete és működése. (Über den Bau und Funktion des Respirationsapparates von Aphelochirus.) 48-66, 94-95

Entz Géza: Nappal repülő denevérek. (Bei Tageshelle fliegende Fledermäuse.) ... 66-67, 95

Entz Géza: Az eperfa paizstetvének előfordulása a magyar királyság területén. (Das Vorkommen der Schildlaus des Maulbeerbaumes im Gebiete der ungarischen Krone.) 67,95

Pongrácz Sándor: A Perla-lárvák mozgásáról. [About the move of the Perla-larvae.] 67-68, 95

Pongrácz Sándor: Húsevők voltak-e az ősvilági kérészek? [Were the prehistoric stoneflies carnivoruos?] 68,95

Szombathy Kálmán: Miképen fogja meg a labirintpók (Agalena similis és labyrinthica) zsákmányát? [How do the spiders Agalena similis and labyrinthica catch their preys?] 68-69, 95

Szombathy Kálmán: Új módszer a paraffinmetszetek felragasztására. [New metod for sticking paraffin slits.] 69-70, 95-96

Soós Lajos: A Valvata pulchella előfordulása. [The occurrence of Valvata pulchella.] 70-71, 96

Soós Lajos: A Leucochroa candidissima szívóssága. [The durability of Leucochroa candidissima.] 71-72, 96

Kertész Kálmán: Kígyók tömeges megjelenése. [Mass-occurrance of snakes.] 72,96 
Szabó-Patay József: A Sysphincta europaea For. újabb lelőhelyei. [New localities of Sysphincta europaea.] 73,96

Horváth Géza: Érdekes vizipoloska a Duna fenekén. [An interesting waterbug at the bottom of the Danube.] $73-75,96$

Biró Lajos: A palaearktikus fauna szárnyatlan Braconidái. [The wingless braconids of the Palearctic.] $75-76,96$

Pongrácz Sándor: Hertwig, O.: Das Werden der Organismen. Eine widerlegung von Darwin's Zufallstheorie. Jena, 1916. [Book review.] 76-86

Entz Géza: Schaxel, J.: Über den Mechanismus der Vererbung. Jena, 1916, p. 1-31. [Book review.] $86-89$

Szakosztályunk ülései. (Comptes rendus des séances de notre section.) 89-91

3-4. füzet:

Entz Géza: A véglények magszerkezetéről és chromatin-reductiójáról. (Második és befejező közlemény.) (Über Kernstruktur und Chromatin-Reduction der Protisten.) 97-118, 161

Szilády Zoltán: A tarka bögölyök faji bélyegei. (Die Artmerkmale der Chrysops-Arten.) $119-134,161-162$

Pell Mária: A Torpedók Lorenzini-féle ampullái. (Über die Lorenzinischen Ampullen des Torpedos.) $135-146,162-163$

Jablonowski József: A fiumei eperfapajzstetü. (Über das Vorkommen der Aulacaspis pentagonia in Fiume.) 146-148, 163

Unger Emil: A Corophium devium elöfordulása a Dunában. (The occurrence of Corophium devium in river Danube.) 148-149, 163

Horváth Géza: Az első eleven barlangi gőte Budapesten. (Der erste lebende Grotten-Olm in Budapest.) 149-150, 163

Horváth Géza: Budapest környékének emlősfaunája száz év előtt. (Die Säugethier-Fauna der Umgegend von Budapest vor 100 Jahren.) $150-151,163$

Nagy Jenő: Schenk Jakab: A magyar birodalom állatvilága. A magyar birodalomból eddig ismert állatok rendszeres lajstroma. Madarak. Kiadta a K. M. Természettudományi Társulat. Budapest, 1917. Magyar és latin nyelven, 1 térképpel. (Fauna regni Hungariae. Aves.) [Book review.] $151-153$

Entz Géza: Pascher, A.: Flagellaten und Rhizopoden in ihren gegenseitigen Beziehungen. Archiv f. Protistenkunde, 38. Bd., Heft 1., 1917. [Book review.] $153-156$

Szüts Andor: Lenhossék Mihály: A sejt és a szövetek. Az általános szövettan vázlata. Budapest, 1918. 354 oldal, 245 ábrával. (Die Zelle und Gewebe. Grundzüge der allgemeinen Histologie.) [Book review.].... $156-158$

Szakosztályunk ülései. (Comptes rendus des séances de notre section.) $158-160$ 


\section{8. kötet - 1919}

\section{1-4 füzet}

Beköszöntő. (Vorwort des neuen Redakteurs.)

Szalay Béla: A hiúz. Állattörténeti tanulmány. (Der Luchs.) $2-12,47$

Szüts Andor: Az Adria tízlábú rákjai. (Előzetes jelentés a Magyar Tengerkutató Bizottságnak Öfelsége "Najade" hajójával végzett állattani gyüjtéseiről.) (Die Decapodenkrebse der Adria.) $13-22,47$

Dudich Endre: A Proturák szervezete és rendszertani helye. (Über die Organisation und systematische Stellung der Proturen.) 22-32, 47

Kotlán Sándor: Adatok a hazai kullancs-fauna ismeretéhez. (Beiträge zur Kenntnis der Zeckenfauna Ungarns.) $33-36,48$

Hankó Béla: A fény hatása a lepkebábok színére. (Einwirkung der Lichtstrahlen auf die Farbe der Schmetterlingspuppen.) [Book review.] 36-39

Szilády Zoltán: Boga Lajos: Adatok a Trichopteron-álczák életmódjának és finomabb alkatának ismeretéhez. I. Izomszövet. I-IV. táblával. Különlenyomat, Múzeumi Füzet. X. köt. 1898. 1-3. füz.-böl. 80 lap. (Beiträge zur Kenntnis der Lebensgewohnheiten und des feineren Baues der Trichopterenlarven. I. Muskelgewebe.) [Book review.] ..... 39-41

Szilády Zoltán: dr. Gelei József: Jegyzetek a fejlődéstan elemeiről és a szövettanból, gyakorlati készítmények alapján. Apáthy professzor tanítása nyomán. Kolozsvár, 1918. Ajtay-nyomda. 1-180 1.. (Grundzüge der Entwickelungslehre und der Histologie.) [Book review.] 42

Karl János: Benkő Ferencz Magyar Linneuszának állatneveiről. (Über die Tiernamen im «Magyar Linneusz») $42-45,48$

Szilády Zoltán: Megjegyzés. [Karl J.: Benkő Ferencz Magyar Linneuszának állatneveiről c. cikkéhez]. (Bemerkungen zum vorigen Aufsatze.)

Éhik Gyula: A házi patkány újabb termőhelyéről Magyarországon. (Neuere Fundorte der Hausratte in Ungarn.) 45-46

Szilády Zoltán: Bögölyök gyüjtése. (Über das Sammeln der Bremsen.) 46

\section{9. kötet - 1920}

\section{1-4. füzet:}

Horváth Géza: Elnöki megnyitó. Az újraalakult állattani szakosztálynak első, 1920. decz. 3án tartott gyülésén. (Eröffnungsrede des Präses.) $1-4,43$

Szilády Zoltán: Meleggyüjtő és meleghárító szinek. (Wärme speichernde und ablenkende Farben.) 4-28, 43-44

Schmotzer Bertalan: Adatok a foltos hiéna külső nemiszerveinek ismeretéhez. (Beiträge zur Anatomie der weiblichen Geschlechtsorgane der Hyaena crocuta.) $28-37,44$ 
Hankó Béla: Dr. L. Adler: Metamorphosestudien an Batrachierlarven. II. Der Einfluss überreifer Eier. Arch. für Entwicklungsmech. Bd. 43. p. 243-360. [Book review.] 37-39

Paszlavszky József. [In memoriam József Paszlavszky.] 39

Mezőkomáromi id. Entz Géza. [In memoriam sen. Géza Entz from Mezőkomárom.] 39-40

Deési Daday Jenő. [In memoriam Jenő Daday from Deés.] ............................................ 40

Szolczai Szaniszló Albert. [In memoriam Albert Szaniszló from Szolcza.] ...................... 40

A magyar zoologia válságos helyzete. [The critical situation of the Hungarian zoology.] 41

Vasvári Miklós: Adatok a házi patkány életmódjának ismeretéhez. [Contributions to the knowledge of the life of the house rat.] $41-42$

Szakosztályunk ülései. (Comptes rendus des séances de notre section.) 42

\section{0. kötet - 1921}

1-4. füzet:

Szilády Zoltán: A gyakorlati állattan jelentősége hazai szempontból. (Über die Wichtigkeit der Angewandten Zoologie mit spezieller Rücksicht auf Ungarn.) $1-13,91$

Pongrácz Sándor: Haeckel Ernőről. (Errinnerung an Ernst Haeckel.) $13-16$

Szüts Andor: Megfigyelések az Adria planktonjáról. (Beobachtungen über den Plankton der Adria.) $17-20,91$

Zimmermann Ágoston: Adatok a vakbél féregnyúlványának összehasonlító anatomiájához. (Közlemény a m. kir. állatorvosi főiskola anatómiai intézetéből.) (Zur vergleichenden Untersuchung des Wurmfortsatzes am Blinddarm.) 20-27, 91-92

Kadocsa Gyula: A csótányokról. (Über die Schaben.) $27-37,92$

Éhik Gyula: Utasítás apró emlősök gyüjtésére és preparálására. (Anweisung zur Sammlung kleiner Säugetiere.) $37-43,92$

Kotlán Sándor: A hazai kullancsok rendszere. (Über die Systematik der ungarischen Zekken.) 43-50, 92

Szilády Zoltán: A szuronyos légy és rokonai. (Über die Stechfliege und deren Verwandte.) $51-58,92$

Pongrácz Sándor: Az állatok röpülése. [Zschokke F.: Der Flug der Tiere. Berlin, 1919]. (Der Flug der Tiere) [Book review.]

Éhik Gyula: Az európai, ázsiai és északafrikai pleistocén áttekintése. [Osborn H. F.: Review of the pleistocene of Europe, Asia and Northern Africa. New York, 1915. 315 lap 20 képpel]. (Review of the pleistocene of Europe, Asia and Northern Africa) [Book review.] $65-72$

Szilády Zoltán: Ujabb nézetek a kotlásról. [New opinions about the incubation.] [Book review.] $72-78$

Zimmermann Ágoston: Házi állatok anatomiája. 1-390 lap 95 képpel. 1920. A pesti könyvnyomda r.-t. nyomása. A szerző kiadása. [Book review.] $78-80$ 
Dr. Wellmann Oszkár: Általános állattenyésztéstan. 301 oldal, 178 képpel és négy színes melléklettel. Budapest, 1921. Kiadja a földmívelésügyi m. kir. minisztérium támogatásával az OMGE könyvkiadó vállalata. Pátria irodalmi vállalat és nyomdai r. t. nyomása. [Book review.] $80-81$

Dr. Hutyra Ferencz: A háziállatok fertőző betegségei. 360 oldal, 157 képpel és három színes melléklettel. Budapest, 1920. Pátria irodalmi vállalat és nyomdai r. t. nyomása. [Book review.] $81-82$

Kieselbach Gyula: Dürken: Einführung in die Experimentalzoologie. Berlin, 1919. [Book review.] $82-85$

Szilády Zoltán: A vérszívó legyek irodalmából. [Book review.] ….............................. 86-87

Szakosztályunk ülései. (Comptes rendus des séances de notre section.) $87-90$

\section{1. kötet - 1922}

1-4. füzet:

Pongrácz Sándor: A halál és az örök élet. (Über Tod und Unsterblichkeit der Organismen.) $1-11,86-87$

Hankó Béla: Torzfejü halak a Magyar Nemzeti Muzeum halgyüjteményéből. (Über monströse Fischköpfe aus der Sammlung des Ung. National Museums.) $11-17,87$

Zimmermann Ágoston: Adatok a ló metszőfogainak anatomiájához és fejlődéstanához. (Beiträge zur Anatomie und Entwicklungsgeschichte der Schneidezähne des Pferdes.) 18-21, 87-88

Szilády Zoltán: A szongáriai cselőpók (Trochosa singoriensis) terjedése. (Über die Verbreitung von Troch. sing, in Ungarn.) 21-24, 88

Kieselbach Gyula: Palesztina és Egyiptom faunájából. (Aus der Fauna Palästinas u. Egyptens.) $25-32,88$

Csiki Ernő, Szilády Zoltán, Pongrácz Sándor \& Horváth Géza: Adatok Szibéria rovarfaunájának ismeretéhez. (Aus der Insektenfauna Sibiriens.) $33-38,88$

Biró Lajos: Szívós életủ apró darazsak. [Tiny wesps with hard life.] .......................... 39-40

Hoffer Endre: Varjak Szibériában. [Ravens i Siberia.] ............................................... 40-41

Hoffer Endre: Szibéria két óriáspókjáról. [About two giant spiders of Siberia.] ........ 41-42

Istók János: Inség a fecskefészekben. [Distress in the swallows' nest.] ........................... 42

Szilády Zoltán: Gyíkölő pók. [Lizard-killer spider.] ...................................................... 42

Szilády Zoltán: Légyfogdosó legyek. [Flycatcher flies.] …........................................... 43

Szilády Zoltán: Hogyan szökdel a sajtkukac? [How jumps the chees worm?] .................. 43

Szilády Zoltán: Szitakötő nyugalmi helyzete. [The relaxing position of the dragonflies.] 43

Szilády Zoltán: Coccinella 7-punctata L. szineződése. [Th colouration of Coccinella 7 -

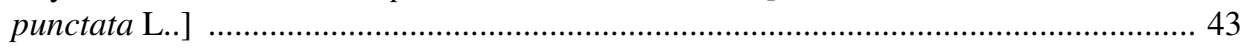

Szilády Zoltán: Tetüevő fülbemászó. [Aphid-eating earwig.] .......................................... 44 
Szilády Zoltán: Bolhák párzása. [Copulation of fleas.] ................................................ 44

Szilády Zoltán: Rablópoloska a házban. [Assassin bug in the house.] .............................. 44

Szilády Zoltán: Cserebogarak holt tettetése. [The dead-pretenting of the May beetles.] ... 44

Szilády Zoltán: Emberszúró kabócza. [Human-picking cycada.] ............................... 44-45

Szilády Zoltán: A hosszuszárnyúság öröklése. [Heritation of long-wingedness.] .............. 45

Szilády Zoltán: A muzem-bogár biologiájából. [About the biology of the carpet beetle.]

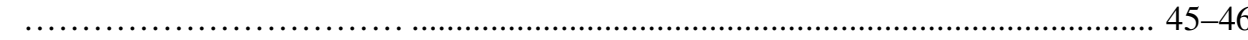

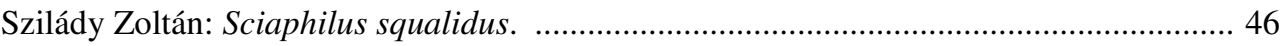

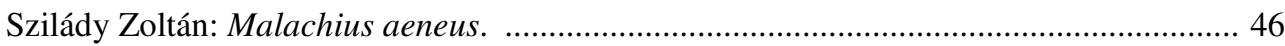

Szilády Zoltán: Tökevő futóbogarak. [Pumpkin-eating carabids.] ...................................... 46

Szilády Zoltán: Papmacska a szőlőben. [Woolly worms in the vine yard.] ....................... 46

Szilády Zoltán: Egy törpedarázs sajátos párzása. [The special copulation of a platygastrid

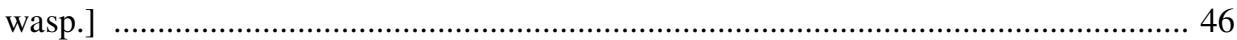

Csiki Ernő: A Magyar Birodalom Állatvilága - Fauna Regni Hungariae. Budapest, 19151920. A Kir. Magy. Természettudományi Társulat kiadása. (Fauna Regni Hungariae.) [Book review.] 47-49

Annales Historico-naturales Musei Nationalis Hungarici. XVII. és XVIII. kötet. [Book

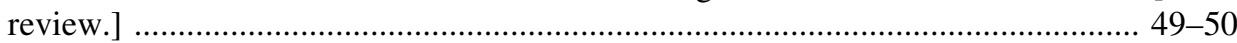

Lambrecht Kálmán: Herman Ottó. Az utolsó magyar polihisztor élete és kora. Budapest,

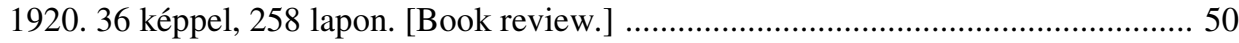

Aquila. XXVI., XXVII., XXVIII. kötet. [Book review.] ............................................... 51

Abonyi Sándor: Dr. Zimmermann Ágoston: Fejlődéstan. Második kiadás. 323 szövegközötti képpel. Budapest, 1920. 308 oldal. [Book review.] ......................... 52-53

Gaál István: Dr. J. Éhik: The glacial-theories in the light of biological investigation. (Annal. Mus. Nat. Hungarici XVIII. Budapest, 1921.) pag. 89-110, 7 rajz. [Book review.] 53-56

Szilády Zoltán: Az agyvelő sejt-architekturája. A Brodmann-féle szövettani tájékok.. [Book

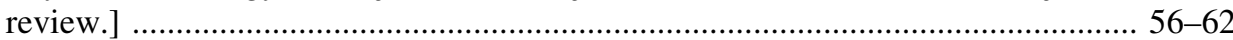

Krause R.: Mikroskopische Anatomie der Wirbeltiere in Einzeldarstellungen I. Säugetiere. Mit 75 Originalabbildungen im Text. Berlin und Leipzig, 1921. Vereinigung wissenschaftlicher Verleger. 186 oldal. [Book review.] .................................... 63-65

Szilády Zoltán: Mai ismeretünk a kolumbácsi légyről. [Wilhelmi J.: Die Kriebelmückenplage. Jena, 1920. 246 1., 24 k.]. [Book review.] ........................... 65-69

Bürger Ottó: Reisen eines Naturforschers im Tropischen Südamerika. (Fahrten in Columbien und Venezuela). 33 képpel, 4 táblával, 464 lapon. [Book review.] .... 69-70

Keller C.: Geschichte der Schweizerischen Haustierwelt. Huber in Frauenfeld, 1919. 84 1., 26 képpel. [Book review.] $71-73$

Szilády Zoltán: Verhandlungen der Deutschen Gesellschaft für angewandte Entomologie. II. Mitgliedersammlung zu München. 1918. Berlin, Parey, 1919. [Book review.] 73-76 
Gaál István: Ihering H. v.: Phylogenie und System der Mollusken. (Abhandlungen d. Archiv. f. Molluskenkunde Bd. I. Heft 1. p. 1-116, 9 rajz). Frankfurt a. M. 1922. [Book review.] 76

Kieselbach Gyula: Banta A. (Carnegie Institut Wash. Publ. Nr. 305.) Ágascsápú rákokkal végzett szelekciós kísérletek. [Book review.]

Dudich Endre: A szongáriai cselőpók (Trochosa singoriensis) őshonosságáról. [About the nativity of the spider Trochosa singoriensis.] $78-81$

Szilády Zoltán: Válasz. [Dudich Endre "A szongáriai cselőpók (Trochosa singoriensis) őshonosságáról" c. írására]. [Antwort. (On Endre Dudich's "About the nativity of the spider Trochosa singoriensis.")]

Chernelházi Chernel István 1865-1922. [In memoriam István Chernel 1865-1922 of Chernelháza.] 82

A magyar orvosok és természetvizsgálók Keszthelyen. [The Hungarian medical doctors and naturalists in Keszthely.] 82

Dr. Bálint Sándor †. [In memoriam Dr. Sándor Bálint.] ............................................... 82

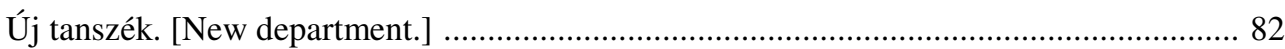

Apáthy István. 1863-1922. [In memoriam István Apáthy. 1863-1922.] .......................... 83

Szakosztályunk ülései. (Comptes rendus des séances de notre section.) ..................... 84-85

\section{Supplement}

Szilády Zoltán: A magyar állattani irodalom repertoriuma I. A legrégibb időktől 1870-ig. [Repertorium of the Hungarian zoological literature I. From the beginning till 1870.]

\section{2. kötet - 1925}

\section{1-2. füzet:}

Fejérváry Géza Gyula: Beköszöntő. (Avant-propos du nouveau rédacteur.) ....... 1-3, 93-94

Hankó Béla: Biologiai állomás a Balaton mellett. (Station biologique sur les rives du Balaton.)

Pongrácz Sándor: A mimikry. (Über Mimikry.) 9-18, 94-95

Abonyi Sándor: Az Entz-féle cytophanokról. (Über die Entz'schen Cytophane.) $18-35,95-97$

Varga Lajos: Az Asplancha Sieboldi Leydig rágókészüléke. (Untersuchungen über den Kauapparat von Asplanciina Sieboldi Leydig.) 35-39, 97-98

Dudich Endre: Faunisztikai jegyzetek. Első közlemény. (Faunistische Notizen. I. Mitteilung.) 39-46, 98

Dudich Endre: Az Abaligeti barlang vak rákjáról. (Über den blinden Krebs der Abaligeter Grotte.) 46-51, 98 
Éhik Gyula: Spalax monticola syrmiensis Méhely Fejér megyéböl. (On the occurrence of Spalax monticola syrmiensis Méhely in the County of Fejér.) 52,98

Fejérváry Géza Gyula: A zoogeographia tárgya és módszerei. (Sujet et méthodes de la zoogeographie.) 53-60, 98-99

Szalay László: A magyarországi Hydracarinák jegyzéke. Az eddigi irodalmi adatok és újabb gyüjtések alapján. (Verzeichnis der Hydracarinen Ungarns. Auf Grund bisheriger literarischer Angaben und neuerer Sammlungen.) 60-70, 99

Fejérváry Géza Gyula: Rendszeres állattan. I. Véglények, Szivacsok, Csalánzók, Laposférgek, Nemathelminthes és Kerekesférgek. II. Gyürüsférgek, Tentaculata, Puhatestüek, Tüskésbőrűek, Öskordások. Írta: Dr. Soós Lajos, a Magyar Nemzeti Múzeum osztályigazgatója. Pécs - Budapest, 1924. A Danubia kiadása. (Zoologie Systématique.) [Book review.] $71-73$

Kieselbach Gyula: Le pigment mélanique de la truite (Salmo lacustris L.) et le mécanisme de sa variation quantitative sous l'influence de la lumiere. Par P. Murisier. Revue Suisse de Zoologie. Geneve, Vol. 28, No 3 \& No 9, 1920 Vol. 28, No 13, 1921. Avec 3 planche. [Book review.] 73-76

Varga Lajos: Tier und Pflanze in intrazellularer symbiose. Von Paul Buchner. Berlin, 1921. Gebr. Borntraeger. XI+462 oldal, 2 tábla és 103 sz.-k. ábra. [Book review.] …… 76-77

Pongrácz Sándor: A Pithecantropus származástani helye. [Book review.] .................. 78-80

Pongrácz Sándor: Bogarak a perm-korból. [Book review.] …………...................... 80-81

Pongrácz Sándor: A Magyar Tudományos Akadémia Balkán-kutatásainak tudományos eredményei. Szerkesztik gróf Teleki Pál és Csiki Ernő. I. kötet. Csiki Ernő állattani kutatásai Albániában. 1. füzet. (Vol. I. Explorationes zoologicae ab E. Csiki in Albania peractae. Fasc. 1.) Budapest, 1923. [Book review.] 81

Fejérváry Géza Gyula: Nagy-Alföldünk állatvilága. Szerkesztette: Dr. Szilády Zoltán. A Debreceni Tisza István Tudományos Társaság Honismertető Bizottságának Közleményei. Első kötet. 3. füzet. Debrecen, 1925. (Faune de la Grande Plaine Hongroise) [Book review.] $81-83,100$

Magyarországi folyóiratszemle. (Revue des périodiques hongrois.) 81

Dr. besenyői Kertész Kálmán: Zoológiai hírek. (Nouvelles zoologiques.) .. 84-88, 100-102

Dr. besenyői Kertész Kálmán. 1867 január 2.-1922 december 28. (Dr. Coloman Kertész de Besenyő.) 89,103

Szakosztályunk ülései. (Comptes rendus abrégés des séances de notre section.) 90-92, 103-104

3-4. füzet:

Pongrácz Sándor: Huxley. (1825-1895). (Huxley (1825-1895)) $105-109,243$

Szilády Zoltán: A melegvérủek testnagyságát szabályozó külső tényezők. (Über die Körpergrössenregulation der Warmblüter durch äussere Faktoren.) .. 110-120, 243-245

Gelei József: Új Paramaecium Szeged környékéröl. Paramaecium nephridiatum nov. sp.. (Ein neues Paramaecium aus der Umgebung von Szeged. Paramaecium nephridiatum n. sp.) $121-159,245-248$ 
Kormos Tivadar: A süttői forrásmészkő-komplexus faunája. (Die Fauna des QuellenkalkKomplexes von Süttő.) $159-175,248-253$

Dudich Endre: Asellus-tanulmányok. (Studi sugli Asellidi.) ..... $175-177,253$

Kolosváry Gábor: Kísérletek a vízisiklóval labirintusban. (Versuche mit der Ringelnatter im Labyrinth.) $178-179,253-254$

Zimmermann Ágoston: A házinyúl izületeiről. (Über die Gelenke des Kaninchens.) 180-189, 254-255

Pongrácz Sándor: Az összegömbölyödő Perisphaeriinák csoportja. Alaktani és phylogeniai tanulmány. (Über die Gruppe der sich einrollenden Perisphaeriinen. Eine morphologische und phyletische Studie.) 190-210, 255-260

Szalay László: Hydracarinák a Balaton környékéről. (Hydracarinen aus der Umgebung des Balatonsees.) 210-214, 261-262

Varga Lajos: Új hydrobiologiai állomások. (Neue hydrobiologische Stationen.) 215-216, 262-263

Szilády Zoltán: Széljegyzetek az Almásy-expedició leírásához. [Book review.] ... 217-219

Éhik Gyula: Osborn: The Age of Mammals in Europe, Asia and North America. New York, 1921. [Book review.] 219-222

Dudich Endre: A Proturákról és a Zorapterákról szóló ismereteink bővülése. [Book review.] 222-223

Dudich Endre: Új rákfajok hazánk faunájában. [New crustacean species in the Hungarian fauna. (Literature review.)]

Dudich Endre: Új légyfajok hazánk faunájában. [New fly-species in the Hungarian fauna. (Literature review.)] 223-224

Dudich Endre: Die Forstinsekten Mitteleuropas. Von K. Escherich. II. Berlin, 1923. Paul Parey. 663 lap, 335 ábrával. [Book review.] 224-225

Dudich Endre: Új élősködő bogár. [A new parasitic beetle (Literature review.)] 225

Varga Lajos: Grundzüge der Hydrobiologie. Von Dr. Ernst Hentschel. Jena, 1923. G. Fischer. VI + 221 lap, 100 ábra. [Book review.] $225-226$

Varga Lajos: Das Leben der Ameisen. Von Dr. Rudolf Brun, Leipzig-Berlin, 1924. Teubner. 211 lap, 60 ábrával. [Book review.] 227-228

Dudich Endre: Beiträge zur rezenten Fauna der Abaligeter Grotte. Von Elemér Bokor. Zoologischer Anzeiger, LXI, 1924, p. 111-121. [Book review.] 228

Urwelt, Sage und Menschheit. Eine naturhistorisch-metaphysische Studie. Von E. Dacqué. 2. veränderte Auflage, München, 1924. [Book review.] 228-229

Dudich Endre: Dr. W. J. Schmidt: Die Bausteine des Tierkörpers in polarisiertem Lichte. Friedrich Cohen, Bonn, 1924. XII+528 lap, 230 szövegközötti ábrával; Dr. W. J. Schmidt: Anleitung zu polarisationsmikroskopischen Untersuchungen für Biologen. Friedrich Cohen, Bonn, 1924. 64 lap, 33 szövegközötti ábrával. [Book review.] 230-231

Kormos Tivadar: Újabb megfigyelések az emlősfogak zománcszerkezetén. [Irodalmi áttekintés]. [Book review.] 
Rapaics Rajmund: A növények élete. R. Francé. Fordította Lambrecht Kálmán. "Dante" kiadása, Budapest, 1925. [Book review.]

Rapaics Rajmund: A világtörténet alapvonalai. H. G. Wells. Fordították Lambrecht Kálmán és Kiss Dezső. "Genius" kiadása, Budapest, 1925. [Book review.]

Hankó Béla: Állattenyésztéstan. I. kötet. Az állattenyésztés biológiája. Általános tenyésztési elvek. Írta: Dr. Schandl József, közgazd. egyet. ny. r. tanár. Budapest, 1925, Eggenberger-féle könyvkereskedés kiadása. 288 oldal, 48 képpel. [Book review.] 233-234

Magyarországi folyóiratszemle. [Review of Hungarian periodicals.] 234-235

Zoológiai hírek. [Zoological news.] 236-237, 263-265

Szakosztályunk ülései. [Sessions of our section.] $238-242,265-266$

\section{3. kötet - 1926}

1-2. füzet:

Zimmermann Ágoston: Elnöki megnyitó. (Antrittsede des Vorsitzenden.) $1-9,116$

Esaki, Teiso: A japáni szigetvilág állatföldrajzi tekintetben (Über die Zoogeographie des japanischen Archipels.) $10-15,116-122$

Gaál István: A Pterosaurusok életmódjának rekonstrukciója. (Die Rekonstruktion der Lebensweise der Pterosaurier.) $16-33,122-129$

Vasvári Miklós: Adatok a zöldgyík-formakör ismeretéhez. (Contributions to the knowledge of the Form-group of Lacerta viridis Laur.) 34-66, 129-132

Mócsy János: A házinyúl kisagyveleje. (Das Kleinhirn des Kaninchens.) $67-73,133$

Rotarides Mihály: Az örvös csiga (Cepaea vindobonensis C. Pfr.) szalagvariációja. (On the Band-variation of Cepaea vindobonensis.) $73-86,133$

Szalay László: Új rheophil Hydracarina Magyarország faunájában (Sperchon Thienemanni Koenike). (Eine für die Fauna Ungarns neue rheophile Hydracarine.) $86-87,133$

Dudich Endre: Faunisztikai jegyzetek. Második közlemény. (Faunistische Notizen. II. Mitteilung.) 87-96, 133-134

Fejérváry Géza Gyula: Paul Kammerer. 96-99, 135-136

Zimmermann Ágoston: Handbuch der vergleichenden Anatomie der Haustiere, bearbeitet von Geheimem Rat Ddr. Wilhelm Ellenberger, o. Professor an der vormaligen Tierärztlichen Hochschule in Dresden i. R. und Geheimem Medizinalrat Ddr. Hermann Baum, o. Professor der Veterinäranatomie an der Universität Leipzig. XVI. Aufl., J. Springer, Berlin, 1926. 1072 oldal, 1373 részben színes képpel. [Book review.] ...... 100

Szalay László: A Hydracarinák kifejlődéséről szóló ismereteink bővülése. [Broadening of our knowledge on Hydracarina development.] [Book review.] 100-101

Dudich Endre: J. Stach: Über die in Polen vorkommenden Felsenspringer (Machilidae) und über die Bedeutung dieser insekten zur Beurteilung einiger zoogeographischen 
Probleme. (Bull. Intern. Acad. Pol. Sci. Lettr., Sér. B, 1925 (1926), p. 633-650). [Book review.]

Dudich Endre: H. Spandl: Die Tierwelt der unterirdischen Gewässer. (Speläologische Monographien, XI, Wien, 1926, pp. 235). [Book review.] 101-102

Dudich Endre: Érdekesebb rákászati irodalom. [Book review.] 102

Dudich Endre: Új hazai állatfajok. [New animals in the Hungarian fauna (Literature review.)] $102-103$

Szalay László: Szakosztályunk ülései. (Comptes rendus abrégés des séances de notre section.) 104-113

A Kir. Magy. Természettudományi Társulat Állattani Szakosztályának szabályzata. (Réglement de la Section Zoologique Royale Hongroise des Sciences de la Société Naturelles.) $113-115$

\section{3-4. füzet:}

Dudich Endre: Dr. Horváth Géza nyolcvanadik születésnapján. 60 év a magyar zoológia szolgálatában. (Zum 80. Geburtstage von G. Horváth.) 137-141, 218-219

Schmid, Basian: Az állatlélektan feladatai és problémái. (Aufgaben und Probleme der Tierpsychologie.) $141-158,219$

Éhik Gyula: A Titanomys fogcsúcsainak helyes értelmezéséről. (The right interpretation of the cheekteeth tubercles of Titanomys.) 159-168, 219-220

Vásárhelyi István: Adatok a földi kutya (Spalax hungaricus hungaricus Nhrg.) életmódjának ismeretéhez. (Contributions to the behaviors of Spalax hungaricus hungaricus Nhrg.) 169-178, 221-226

Rotarides Mihály: Adatok az Alföld puhatestü-faunájának ökológiájához. (Contributions a l'oecologie des mollusques de la Grande Plaine Hongroise. Essai faunistique et oecologique.) $179-187,226$

Soós Lajos: Ki a fölfedezője a biogenetikai alaptörvénynek?. (Who is the author of the biogenetical law?) $188-189,226$

Pongrácz Sándor: A. N. Sewertzoff: Der Ursprung der Quadrupeda. Palaeont. Zeitschrift, 1926. p. 76-95. [Book review.] 190-194

Abonyi Sándor: A házinyúl természetrajza, tenyésztése és hasznosítása. Írta dr. Zimmermann Ágoston, m. kir. állatorvosi főiskolai ny. r. tanár, egyetemi m. tanár és mb. elöadó. 319 lap, 214 szövegközti képpel. Budapest, 1927. A Kir. Magy. Természettudományi Társulat kiadása. (Histoire naturelle, élevage et utilisation économique du Lapin) [Book review.] 194-196

Bartucz Lajos: Lambrecht Kálmán: Az ősember. Dante kiadás, Budapest, 1926. (L'homme ancestral.) [Book review.] 196-199

Pongrácz Sándor: Verzár Frigyes: Életről, betegségről, halálról. Budapest, 1926. (Athenaeum). (Sur la vie, la maladie et la mort.) [Book review.] 199-201

Soós Lajos: Haffner, K. von: Die Sinnesorgane der Linguatuliden, nebst einer Betrachtung über die systematische Stellung dieser Tiergruppe. Zeitschr. f. wiss. Zoologie, 128. Bd. 1926. p. 201-252. [Book review.] 201-203 
Dudich Endre: Biologie der Tiere Deutschlands. Borntraeger, dr. Schultze P.. [Book review.]

Dudich Endre: Abderhalden, E.: Handbuch der biologischen Arbeitsmethoden. Abt. IX. Methoden zur Erforschung der Leistungen des tierischen Organismus, Teil 2., 1 Hälfte. (Methoden der Süsswasserbiologie), Heft 1. (Lfrg. 115, 1923), 2 (Lfrg. 173, 1925) 3 (Lfrg. 180, 1925), 4 (Lfrg. 184). [Book review.]

Magyarországi folyóiratszemle. [Review of Hungarian periodicals.] 204-207

Zoológiai hírek. [Zoological news.] 207-208, 228

Szalay László: Szakosztályunk ülései. [Sessions of our section.] $209-217,228-232$

\section{4. kötet - 1927}

1-2. füzet:

Nagy Jenő: Európa madárfaunájának ökológiai egységek szerint való csoportosítása. (Gruppierung der Avifauna Europa's nach ökologischen Einheiten.) ...... 1-28, 104-107

Wagner János: Újabb adatok a magyarországi Limnaeák ivarszerveinek anatomiájához. (Nouvelles contributions a l'anatomie de l'appareil genital des Limnées de Hongrie.) 29-39, 107-108

Varga Lajos: Kísérletek egy új élvefestő anyaggal. (Versuche mit einer neuen Vitalfärbung.) 40-46, 108

Schenk Jakab: A balkáni berki poszáta (Cettia cetti sericea Temm.) Délmagyarországon. (Das Vorkommen von Cettia cetti sericea Temm. in Südungarn.) ........ 46-53, 108-109

Zimmermann Ágoston: A bordák ú. n. harántizmáról. (Über die „Quermuskeln" der Rippen.) 53-60, 109-110

Soós Lajos: Néhány faunisztikai és ökológiai adat. (Faunistical and oecological notes.) 60-70, 110-112

Szalay László: Viziatkák a Dunából. (Wassermilben aus der Donau.) 70-76, 112-116

Éhik Gyula: A szápári Anthracotherium. (The Anthracotherium valdense szaparense, $\mathrm{n}$. subsp.) $77-81,116-120$

Verhoeff, Karl W.: Adatok a Nagy Magyar Alföld Diplopoda-faunájának ismeretéhez. 106. Diplopoda közlemény. (Beiträge zur Kenntnis der Diplopodenfauna des Ungarischen Tieflandes. 106. Diplopoden-Aufsatz.) $81-83,120-122$

Soós Lajos: Stempell, Walter: Zoologie im Grundriss. Berlin, 1926, Borntraeger. [Book review.] 84-86

Soós Lajos: Pelseneer, P.: La proportion relative des sexes chez les animaux et particulierement chez les Mollusques. (Mémoires. Académie Royale de Belgique; classe des sciences. T. VIII., fasc. 11. Bruxelles, 1926). [Book review.] ........................ 86-88

Soós Lajos: Geyer, D.: Unsere Land- und Süsswasser-Mollusken. Einführung in die Molluskenfauna Deutschlands. Dritte, vollständig neubearbeitete Auflage. Stuttgart, 1927. K. G. Lutz. [Book review.] 
Dudich Endre: Új állatfajok Magyarország faunájában. [Irodalmi áttekintés]. [New animals in the Hungarian fauna (Literature review.)] 89-91

Dudich Endre: Mödlinger Gusztáv: Adatok a Magas-Tátra és környéke planáriafaunájához. (Mathemat. és Természettud. Értesítő, XLIII, 1926, p. 585-596). [Book review.]

Dudich Endre: Zerkowitz, A.: Über die Lepidopterenfauna Ungarns. (Verhandl. III. Intern. Entomol. Kongr. Zürich, 1926. p. 204-215). [Book review.] ............................. 91-92

Rotarides Mihály: Lais, R.: Dr. Hans Kaufmann's hinterlassene Schneckensammlung. Ein Beitrag zur Kenntnis der Schneckenfauna Südbadens und ihrer Beziehungen zum Klima. (Ber. d. Naturf. Ges. Freiburg i. Br. 25, 1925, 1-74 oldal, 28 ábra és 13 táblázat). [Book review.] 92-93

Rotarides Mihály: Boettger, C. R.: Untersuchungen über die Entstehung eines Faunenbildes. Zur Zoogeographie der Weichtiere Schlesiens. (Zeitschr. f. Morphol. u. Ökol. d. Tiere. Abt. A. d. Zeitschr. f. wiss. Biol., 6. kötet, 2. füzet, 1926. 333-414 oldal). [Book review.]

Nagy Jenő: Magyarországi folyóiratszemle. [Review of Hungarian periodicals.] ....... 93-95

Szalay László: Szakosztályunk ülései. [Sessions of our section.] 95-103, 123-124

3-4. füzet:

Nopcsa Ferenc: Fejlődéstörténeti és örökléstani következtetések a hüllők tanulmányozásából. (A study on Reptiles bearing upon phylogeny and heredity.) $125-143,206$

Rotarides Mihály: A variabilitásról és tanulmányozásának módszereiről. Malakozoologiai tanulmány. (Sur la variabilité et les méthodes de son étude. En consideration speciale de la classification systematique en malacologie.) 143-163, 206-207

Soós Lajos: Adatok a magyarországi barlangok Mollusca-faunájának ismeretéhez. (Contributions to the knowledge of the mollusc fauna of some Hungarian caves.) 163-180, 207-211

Kolosváry Gábor: Lélektani kísérletek hangyákkal. (Psychologische Versuche mit Ameisen.) $180-184,212$

Soós Lajos: A budapesti X-ik Nemzetközi Zoológiai Kongresszus. (Le $\mathrm{X}^{\mathrm{e}}$ Congrés International de Zoologie, tenu á Budapest.) $184-186,212$

Soós Lajos: Hankó Béla: A megujhodás. Budapest (1927), Athenaeum. (La régénération.) [Book review.] $187-188$

Éhik Gyula: Dr. Lovassy Sándor: Magyarország gerinces állatai és gazdasági vonatkozásaik. XI + 895 oldal, 387 képpel. Budapest, 1927. Kir. Magy. Természettudományi Társulat kiadása. (Les Vertébrés de la Hongrie et leurs rapports á l'agriculture) [Book review.] $189-190$

Éhik Gyula: Dr. Schandl József: Állattenyésztéstan. II. A szarvasmarha és a bivaly tenyésztése. VI + 288 oldal, 103 képpel. Budapest, 1926. Eggenberger-féle könyvkereskedés. (Élevage des animaux domestiques. Élevage des races taurines et du buffle) [Book review.] 
Varga Lajos: Thienemann, August: Die Binnengewässer Mitteleuropas. Stuttgart, 1926. E. Schweizerbart. 88 rajz, 255 lap. [Book review.]

Éhik Gyula: Kittenberger Kálmán: Vadász- és gyüjtőúton Kelet-Afrikában. 1903-1926. 530 oldal, 202 münyomatos képpel és 1 térképpel. Budapest, 1927. Franklin-Társulat kiadása. (Voyage d'un naturaliste-chasseur dans l'Afrique Orientale.). [Book review.] 192-193

Lambrecht Kálmán: Válasz "Az ősember" taglalatjára. (L'homme ancestral) 193-195

Szalay László: Szakosztályunk ülései. [Sessions of our section.] 195-203, 213-215

Zoológiai hírek. [Zoological news.] 204-205, 215

\section{5. kötet - 1928}

1-2. füzet:

Dudich Endre: A magyar állatvilág kutatásának megszervezése. (Organisationsvorschlag zur faunistischen Erforschung Ungarns.) $1-15$

Zimmermann Ágoston: Adatok a carpalis ízület összehasonlító anatómiájához. (Zur vergleichenden Anatomie des Karpalgelenkes.) ................................................ 15-21

Wagner János: Limnaea tanulmányok. (Limnaea-Studien.) ........................................ 21-38

Dudich Endre: Faunisztikai jegyzetek. (Harmadik közlemény.) (Faunistische Notizen. III.) $38-45$

Gelei József: Vízbejáró házatlan csiga. (Eine hydrophile Limacide.) ........................ 45-47

Rotarides Mihály: Apróbb állattani megfigyelések. (Kleine zoologische Beiträge.) ... 48-53

Éhik Gyula: Újabb adatok Magyarország emlősfaunájának ismeretéhez. (Neuere Beiträge zur Säugetierfauna Ungarns.) ........................................................................... 54-57

Éhik Gyula: A keleti sün (Erinaceus roumanicus Barr. Ham.) fölös zápfogáról. (The extra molar of the Eastern Hedgehog.) ....................................................................... 58-59

Kolosváry Gábor: Morfologiai apróságok a szongáriai cselőpókról. (Beiträge zur Morphologie von Trochosa singoriensis.) ......................................................... 59-65

Pongrácz Sándor: Westenhöfer, M.: Über die Erhaltung von Vorfahrenmerkmalen beim Menschen, insbesondere über eine progonische Trias und ihre praktische Bedeutung. Medizinische Klinik, 1927. Nr. 37.. [Book review.] 65-67

Pongrácz Sándor: Tillyard, R. J.: The Ancestry of the Order Hymenoptera. Trans. Ent. Soc. London, 1927, V. 75. p. 307-318, 2 szövegábrával. [Book review.] .................... 67-70

Dudich Endre: Hrabe \& Cernosvitov: Über eine neue Lumbriculiden-Gattung Anastylus parvus n. g. n. sp. aus Karpathorussland. (Zoolog. Anzeiger, 71. 1927. p. 203-207). [Book review.]

Dudich Endre: Szalay L.: Eine neue Wassermilbe aus dem Balaton-See. (Zoolog. Anzeiger, 71. 1927. p. 279-281). [Book review.] 
Dudich Endre: Gelei J.: Eine neue Blindtriclade aus Ungarn. (Zoolog. Anzeiger, 72. 1927. p. 35-46. [Book review.] 70

Dudich Endre: Attems, C.: Neue Chilopoden. (Zool. Anzeiger, 72. 1927. p. 291-305). [Book review.]

Dudich Endre: Reuss, T.: Beschreibung neuer Vipern aus Jugoslavien. (Zool. Anzeiger, 71. 1927. p. 215-223). [Book review.]

Dudich Endre: Méhely, L. v.: Gibt es zweiäuige Trichonisciden? (Zool. Anzeiger, 72. 1927. p. 2-4). [Book review.]

Dudich Endre: Verhoeff, K. W.: Über einige südosteuropäische Trichonisciden. (Zool. Anzeiger, 70. 1927. p. 200-223). [Book review.]

Lambrecht Kálmán: Weigelt, J.: Rezente Wirbeltierleichen und ihre paläobiologische Bedeutung. XVI+227 lap, 38 fénynyomatú táblával és 28 szövegképpel. Leipzig, Max Weg. 1927. [Book review.] $71-72$

Gelei József: Hempelmann, Friedrich: Tierpsychologie vom Standpunkte des Biologen. Akademische Verlagsgesellschaft M. B. H. Leipzig, 1926. 676 old., 134 szövegközti ábra. [Book review.] $72-74$

Dudich Endre: Chappuis, P. A.: Die Tierwelt der unterirdischen Gewässer. (Die Binnengewässer, III. 1927. pp. 175, Stuttgart, Schweizerbart). [Book review.] 74

Dudich Endre: Gelei, J. v.: Der Bau der Tricladenmusculatur. (Zool. Anzeiger, 73. 1927. p. 21-32). [Book review.]

Dudich Endre: Hase, A.: Aufgaben und Einrichtung des Laboratoriums für physiologische Zoologie an der Biologischen Reichsanstalt für Land- und Forstwirtschaft zu BerlinDahlem nebst Beschreibung einiger neuer, daselbst gebauter Apparate. (Zool. Anzeiger, 73. 1927. p.151-183). [Book review.] 74-75

Fejérváry Géza Gyula: Lambrecht Kálmán: Az ősember elődei. (Az ősállatok). 332 oldal, 150 szövegképpel, 40 táblával és 24 mélynyomású táblával. Budapest, 1927. Dante kiadás. (Les contemporains de l'homme ancestral: les animaux ancestraux) [Book review.] 75-78

Soós Lajos: Báró Fejérváry Géza Gyula: Élet, szerelem és halál. Biologia. (Budapest, 1927.) Révai kiadás. (Vie, Amour et Mort. Biologie) [Book review.] $78-80$

Szalay László: Lundblad, O.: Die Hydracarinen Schwedens. I. Beitrag zur Systematik, Embryologie, Ökologie und Verbreitungsgeschichte der swedischen Arten. 16 táblával és 254 szövegábrával. (Inaug. Diss.) Zool. Bidrag Uppsala, 1927, Bd. 11. p. 185-540. [Book review.] $80-81$

Szabó-Patay József: Dr. Dudich Endre: Rendszeres állattan III. Ízeltlábúak (Arthropoda). 45 szövegrajzzal. Pécs, 1927. A Danubia kiadása. (Zoologie Systématique. III. Arthropodes) $81-82$

Koppányi József: Frisch, K. v.: Aus dem Leben der Bienen. Mit 91 Abbildungen. Berlin, 1927. Verlag von Julius Springer. [Book review.] $82-83$

Soós Lajos: Baloghné Hajós Terézia: Állat-térképek. (Budapest, 1928). (Les cartes zoogéographiques.) [Book review.] 
Soós Lajos: Czógler Kálmán: A szegedvidéki kagylók. Faunabiológiai tanulmány. (Szeged, 1927.) Megjelent a szegedi állami Baross Gábor reáliskola 1926-27-ik évi értesítőjében.

1-29 oldal. (Des Lamellibranches des environs de Szeged.) [Book review.]......... 83-84

Soós Lajos: Magyarországi folyóiratszemle. [Review of Hungarian periodicals.] ...... 84-85

Szalay László: Szakosztályunk ülései. [Sessions of our section.] ............................... 85-90

3-4. füzet:

Soós Lajos: A bátorligeti ősláp Mollusca-faunája és az Alföld multjának kérdése. (The mollusc fauna of the moorland of Bátorliget and the Great Hungarian Plain's past.) $103-113,177-178$

Gaál István: A csigák öszi költözésének egy megfigyelt esete. (Beobachtung eines verunglückten Schneckenzuges im Herbst.) $113-124,178-181$

Verhhoeff, K. W.: Zur Kenntnis der Diplopodenfauna Ungarns. 109. Diplopoden-Aufsatz (Chilopoden) $=$ Adatok Magyarország Diplopoda-faunájához. 109. Diplopodaközlemény. (Zur Kenntnis der Diplopodenfauna Ungarns. 109. Diplopoden-Aufsatz (Chilopoden).) 124-126, 182-199

Hasskó Sándor: A szövetek differenciálódása in vitro. (Über die Differentierung der Gewebe in vitro.) 126-132, 199-200

Szalay László: Adatok a Limnesia undulata O. F. Müll. postembryonalis fejlődéséhez. (Beiträge zur Kenntnis der postembryonalen Entwicklung von Limnesia undulata O. F. Müll.) 133-139, 200-203

Éhik Gyula: Adatok a nagy pele (Myoxus glis L.) életmódjának ismeretéhez. (Contributions to the knowledge of the life history of the dormouse (Myoxus glis L.).) .... 139-140, 203

Éhik Gyula: Adatok a mezei görény (Mustela eversmanni hungarica Éh.) elterjedéséhez. (Contributions to the knowledge of the geographical distribution of the polecat (Mustela eversmanni hungarica Éh.) in Hungary-) 140,204

Abonyi Sándor: A Protohydra Leuckarti Greef szervezete és élete kamcsatkai előfordulása kapcsán. (Bau und Leben von Protohydra Leuckarti Greeff auf Grund ihres Vorkommens auf Kamtschatka.) $141-151,204$

Gaál István: A bajóti Kiskőoldal barlangjának diluviális emlős-faunája. (Diluviale Säugetierfauna aus der Höhle des „Kiskőoldal” bei Bajót.) 151-154, 204-205

Rotarides Mihály: A zöld varangy (Bufo viridis Laur.) porontyainak fölnevelése. (Zur Methodik eines Kaulquappenversuches.) 154-157, 205-206

Wagner János: Faunisztikai adatok Közép-Ázsiából. (Contributions to the knowledge of Central Asiatic molluscs.) 157-160, 206

Gelei József: Punnett, R. C.: Az átöröklés. 8 táblával és 53 szövegábrával. A 7-ik angol kiadás alapján fordította Soós Lajos. Budapest, 1928. K. M. Természettud. Társulat kiadványa. (Mendelism) [Book review.] 160-162

Soós Lajos: Goldschmidt, Richard: Die Lehre von der Vererbung. Berlin, 1927. J. Springer. (Verständliche Wissenschaft, 2. Band). [Book review.] 162-164 
Gelei József: Kükenthal, W.: Leitfaden für das zoologische Praktikum. 9. kiadás, 178 szövegközti rajzzal. Átdolgozta E. Matthes. Jena 1928. G. Fischer. p. I-VIII, 1-360. [Book review.] $164-165$

Soós Lajos: Stolz, K. R.: Evolution and Genesis. Boston, (1927). [Book review.] . 165-166

Unger Emil: Dr. Hankó Béla: A hal és a halgazdaság. A szövegben 56 képpel. Kiadja a Kir. Magyar Természettudományi Társulat. Budapest, 1928. 252 oldal. (Le Poisson et la Pisciculture.) [Book review.] $166-167$

Wagner János: Wolsky Sándor: Adatok a szárazföldi Isopodák szemének ismeretéhez. Bölcsészetdoktori értekezés. Budapest, 1928. 1-29 oldal. (Contributions á la connaissance des yeux des Isopodes terrestres.) [Book review.] $167-168$

Wagner János: Kesselyák Adorján: Miként fejlődött a Haplophthalmusok párzószerve? Bölcsészetdoktori értekezés. Budapest, 1928. p. 1-19 oldal. (Comment l'organe copulateur des Haploplithalmes s'est-il développé?) [Book review.] 168

Dudich Endre: Dr. Bokor Elemér. (1887-1928). (Dr. E. Bokor.) $168-169,207$

Szalay László: Szakosztályunk ülései. [Sessions of our section.] 169-176, 207-208

\section{6. kötet - 1929}

1-2. füzet:

Zimmermann Ágoston: Az ízületi porcokról. (Ueber die Gelenkknorpeln.) $1-10$

Rotarides Mihály: Adatok a csigák helyváltoztatásával kapcsolatos kérdések anatomiai megvilágításához.(Beiträge zur anatomisch-physiologischen Erklärung der Schneckenbewegung.) $10-34$

Gelei József: A Balaton állatvilágának néhány különlegessége. (Über einige Spezialitäten der Tierwelt des Balatons [Plattensee].) $35-58$

Wagner János: Biometrikai vizsgálatok a Planorbisok házán. (Biometrische Untersuchungen an Schalen von Planorbiden.) .............................................. 59-62

Örösi Pál Zoltán: Tanulmányok a petéző munkásméhröl. I. (Studien an eierlegenden Arbeitsbienen.) $63-84$

Vásárhelyi István: Adatok két apró emlős életmódjának ismeretéhez. (Beiträge zur Kenntnis der Lebensweise zweier Kleinsäuger.) $84-91$

Szabó-Patay József: A házi méh királynőjének ivarkészüléke. I. Az ondótáska szerkezete és müködése. (Studien über den Geschlechtsapparat der Königin von Apis mellifica L.)

Gelei József: Doflein \& Reichenow: Lehrbuch der Protozoenkunde. Eine Darstellung der Naturgeschichte der Protozoen mit besonderer Berücksichtigung der parasitischen und pathogenen Formen. Begründet von franz Doflein, neubearbeitet von Prof. Dr. Eduard Reichenow. Fünfte Auflage. I. Teil: Allgemeine Naturgeschichte der Protozoen, mit 388 Abbildungen im Text. Jena, Verlag von Gustav Fischer, 1927; II. Teil: Spezielle Naturgeschichte der Protozoen, u. ott. 1928. [Book review.] 104-105 
Gelei József: Selenka \& Goldschmidt: Zoologisches Taschenbuch für Studierende zum Gebrauch bei Vorlesungen und praktischen Übungen. Achte, verbesserte Auflage von Dr. J. Seiler, Verlag Georg Thieme, Leipzig, 1929. Két füzet. [Book review.] ......... 106

Gaál István: Baloghné Hajós Terézia: Harc az életért. Képek a természetből. Mühlbeck Károly rajzaival. Budapest, Singer és Wolfner. (1928). [Book review.] ............ 106-108

Pongrácz Sándor: Maurer, Fr.: Der Mensch und seine Ahnen. Das Werden des Menschengeschlechts. Berlin, 1929. Verlag Ullstein. [Book review.] ................ 108-110

Lambrecht Kálmán: Stensiö Cephalaspida-monografiája. [Book review.] .............. 110-111

Lambrecht Kálmán: Schmidt, M.: Die Lebewelt unseres Trias. 2300 szövegrajzzal, 461 lap. Öhringen, Hohenlohe-cég kiadása, 1928. [Book review.] ................................ 111-112

Unger Emil: Lenz, Friedrich: Einführung in die Biologie der Süsswasserseen. (Biologische Studienbücher, herausgegeben von Walther Schoenichen. IX. kötet. Berlin, 1928. Julius Springer). 221 oldal, 104 képpel. [Book review.]

Unger Emil: Hankó Béla: Rendszeres állattan. IV. A gerincesek általános jellemzése és a halak. 47 rajzzal. Pécs, Danubia kiadás. Tudományos Gyüjtemény 29. sz. kötete. 107 oldal. [Book review.] $112-113$

Soós Lajos: Xe Congres international de zoologie. Tenue a Budapest du 4 au 10 septembre 1927. Publié par E. Csiki, sécrétaire générale du congres. pp. 1-1620. Budapest, 1929. [Book review.] $113-114$

Dudich Endre: Dr. Kolosváry Gábor: Magyarország kaszáspókjai - Die Weberknechte Ungarns. Szeged - Budapest, 1929, a Studium kiadása. 112 oldal, 11 táblával és 67 szövegközti ábrával. Magyar és német szöveg. [Book review.] 114-118

Magyarországi folyóiratszemle. [Review of Hungarian periodicals.] ...................... 118-121

Szakosztályunk ülései. [Sessions of our section.] $122-127$

3-4. füzet:

Zimmermann Ágoston: Elnöki beszámoló. (Bericht des Vorsitzenden.) $129-133$

Csiki Ernő: Egy fejezet a magyar zoologia történetéböl. (Válasz Dr. Méhely Lajos-nak). (Ein Kapitel aus der Geschichte der ungarischen Zoologie.) 133-139

Pongrácz Sándor: Jaekel Ottó emlékére. (1863-1929). (Dem Andenken Otto Jaekel's.) 139-145

Abonyi Sándor: Eulimnadia victoriae Brady = Limnadia Hislopi (Baird) Brady = Cyclestheria Hislopi (Baird) Sars. (Eulimnadia victoriae Brady = Limnadia Hislopi (Baird) Brady = Cyclestheria Hislopi (Baird) Sars.) 145-149

Vásárhelyi István: Pusztapó apróemlős-faunája. (Die Kleinsäugerfauna von Pusztapó.) $150-153$

Vásárhelyi István: Adatok a háromövü csíkosegér (Sicista loriger trizona Pet.) előfordulásához s életmódjához. (Beiträge zum Vorkommen und zur Lebensweise der Dreistreifenmaus.) $153-155$

Wagner János: Faunisztikai közlemények. (Faunistische Mitteilungen.) ................. 156-164

Gelei József: A véglények idegrendszere. (Über das Nervensystem der Protozoen.) 164-190 
Fejérváry Géza Gyula: Francé, Raoul H.: Der Weg zu mir. Der Lebenserinnerungen erster Teil. Mit 11 Vollbildern. Alfred Körner Verlag, Leipzig, 1927. 236 old. [Book review.] 191-192

Pongrácz Sándor: Abel, O.: Das biologische Trägheitsgesetz. (Biologia generalis, IV. Bd., 1928. p. 1-102). [Book review.] 192-194

Varga Lajos: Péterfi, Tibor: Methodik der wissenschaftlichen Biologie. Berlin, Springer, 1928. I. kötet: Allgemeine Morphologie, XIV+1425 lap; II. kötet: Allgemeine Physiologie, X+1219 lap. [Book review.] 194-195

Varga Lajos: Mislowitzer, Ernst: Die Bestimmung der Wasserstoffionenkonzentration von Flüssigkeiten. Berlin, 1928. J. Springer, 184 rajz, X+378 lap. [Book review.] .. 195-196

Varga Lajos: Thienemann, August: Das Leben im Süsswasser. Eine Einführung in die biologischen Probleme der Limnologie. Jedermanns Bücherei, Abt. Biologie, herausgegeben von W. Schoenichen. Breslau, F. Hirt. 108 lap. [Book review.] ........ 196

Éhik Gyula: Kittenberger, Kálmán: Big game hunting and collecting in East Africa. London, 1929. [Book review.] 196-197

Dudich Endre: Lengerken, H. von: Lebenserscheinungen der Käfer. (Wissenschaft und Bildung, Nr. 245. Chelle \& Mayer, Leipzig, 1928. 147 1.). [Book review.] 197

Wagner János: Kretzoi Miklós: Felida tanulmányok. (2. Aeluroidea közlemény). 9 ábrával és 1 származástani táblázattal. 1-22 oldal. Budapest. A Magy. Kir. Földtani Intézet házinyomdája. 1929. [Book review.] 197-198

Kolosváry Gábor: Válasz dr. Dudich Endrének a "Magyarország kaszáspókjai" c. dolgozatomra írt kritikai ismertetése tárgyában. [Answer to dr. Endre Dudich's critics about my work "Magyarország kaszáspókjai".] 198-201

Dudich Endre: Viszonválasz Dr. Kolosváry Gábornak. [Reply to Dr. Gábor Kolozsváry.] 201-202

Magyarországi folyóiratszemle. [Review of Hungarian periodicals.] 203

Szalay László: Szakosztályunk ülései. [Sessions of our section.] 204-211

\section{7. kötet - 1930}

\section{1-2. füzet:}

Horváth Géza: A magyar orvosok szerepe Magyarország állatvilágának kutatásában. (Le rôle des médecins hongrois dans l'exploration de la fauné de Hongrie.) ................... 1-6

Soós Lajos: Két Clausilida rendszertani helye. (The systematic position of two Clausiliids.) 6-17

Varga Lajos: Adatok a Rhinops fertőensis biológiájához. (Beiträge zur Biologie von Rhinops fertöensis.) $17-35$

Hasskó Sándor: Adatok a struc bőrének szerkezetéhez. (Über den Bau der Sfrausshaut.) 35-40 
Kormos Tivadar: Új adatok a püspökfürdői Somlyóhegy preglaciális faunájához. (Beiträge zur Präglazialfauna des Somlyóberges bei Püspökfürdő.) 40-62

Dudich Endre: Az Aggteleki-barlang állatvilágának élelemforrásai. (Die Nahrungsquellen der Tierwelt in der Aggteleker Tropfsteinhöhle.) $62-85$

Soós Lajos: A Daudebardia postembryonális fejlődéséröl. (Ein Beitrag zur Kenntnis der postembryonalen Entwickelung von Daudebardia.) 85-93

Vasvári Miklós: Új harkály a magyar faunában. (Ein neuer Specht in der Ungarischen Fauna.) 93-97

Wagner János: Újabb adatok a Milax-fajok ismeretéhez. (Neue Beiträge zur Kenntnis der Milax-Arten.) 97-107

Varga Lajos: Möllendorff, Wilhelm: Handbuch der mikroskopischen Anatomie des Menschen, I. Band: Die lebendige Masse. 1. Teil: Allgemeine mikroskopische Anatomie und Organisation der lebendigen Masse. (XII + 626 oldal, 453 rajzzal). 2. Teil: Wachstum und Vermehrung der lebendigen Masse. (IX + 807 oldal, 464 rajzzal). Berlin, J. Springer, 1929. [Book review.] 107-109

Kormos Tivadar: Stehlin, H. G.: Bemerkungen zu der Frage nach der unmittelbaren Ascendenz des Genus Equus. Mit 4 Textfiguren. (Bericht über die neunte Jahresversammlung der Schweizerischen Paläontologischen Gesellschaft. Eclogae geologicae Helvetiae, Band 22, No. 2., 1929. Basel. 186-201 1.). [Book review.] 109-111

Wagner János: Stolmár László: Hazai békáink bőrének szöveti szerkezete. Bölcsészetdoktori értekezés. Budapest, Stephaneum nyomda és könyvkiadó R. T. 1929. p. 1-32, I-VI tábla. [Book review.]

Wagner János: Lameere, Aug.: Précis de Zoologie. tome I. La cellule-L'espéce-Les Protozoaires-Caracteres fondamentaux des métazoaires-Les Spongiaires-Les Coelentéres. Paris, 1929. Gaston Doin \& Cie, éditeurs. [Book review.] ............ 112-113

Soós Lajos: Szilády Zoltán: A magyar állatvilág multja és jelene. (Megjelent a "Magyarország Vereckétől napjainkig" c. mű 3. kötetében. p. 399-440). [Book review.] .... 113-14

Magyarországi folyóiratszemle. [Review of Hungarian periodicals.] ...................... 114-115

Szalay László: Szakosztályunk ülései. [Sessions of our section.] $116-124$

3-4. füzet:

Szilády Zoltán: Állatföldrajzi területeink kérdéséhez. (Zur Frage unserer tiergeographischen Gebiete.) $125-130$

Hasskó Sándor: Az orang-után fogváltása, tejfogazata és állkapcsának lécszerkezete. (Der Zahnwechsel, das Milchgebiss und der Unterkiefer-Balkenbau des Orang-Utan.) 131-143

Kolosváry Gábor: A szongáriai cselőpók párosodása. (Über die Paarung der Trochosa singoriensis.) $143-150$

Gebhardt Antal: Adatok a Coraebus fasciatus Vill. (Buprestidae) fejlődéstanához, különös tekintettel a báb kiszíneződésének folyamatára. (Daten zur Entwicklungsgeschichte des 
Coraebus fasciatus Vill. (Col. Bupr.), mit besonderer Berücksichtigung des Ausfärbungprocesses der Puppe.) $151-163$

Klie, Walter: Egy új, föld alatt élő Candona-faj. (Eine neue, unterirdisch lebende Art der Ostracodengattung Candona.) 163-167

Wagner János: Újabb adatok a Dunántúl puhatestü-faunájához. (Neue Mitteilungen zur Molluskenfauna Ungarns.) $167-172$

Vásárhelyi István: A vakondok vára és a kószapocok fészke. (Die Burg von Talpa europaea L. und das Nest von Arvicola scherman Shaw.) 173-181

Zimmermann Ágoston: A házinyúl és mezei nyúl szívének összehasonlító anatómiájához. (Beiträge zur vergleichenden Anatomie des Kaninchenherzens.) 181-191

Pongrácz Sándor: Abel, O.: Paläobiologie und Stammesgeschichte. Verlag von G. Fischer, Jena, 1929. Mit 224 Abbildungen im Text. p. 1-424. [Book review.] 191-193

Soós Lajos: Hentschel, E.: Das Leben des Weltmeeres. Verständliche Wissenschaft, 6. Bd. Leipzig, 1929. Julius Springer. [Book review.] 193-194

Soós Lajos: Boon, Lee: Crustacea: Stomatopoda and Brachyura. Bulletin of the Vanderbilt Marine Museum. Vol. II. Scientific Results of the Cruises of the Yachts "Eagle" and "Ara", 1921-1928. William K. Vanderbilt, Commending. Huntington, 1930. [Book review.]

Soós Lajos: Éhik Gyula: Prémek és prémes állatok. Szent István könyvek, 94. szám. Budapest, 1931. [Book review.] 194-195

Éhik Gyula: Zammarano, V. T.: Le colonie Italiane. Fauna e Caccia. Roma, 1930. [Book review.]

Wagner János: Szemere Zoltán: A Magyarországon előforduló ragadozó madarak meghatározója. Budapest, 1930. A szerző saját kiadása. Stephaneum nyomda r. t. 1-80 oldal, 12 szövegképen és 8 (1 színes) táblán 174 rajzzal. [Book review.]

Éhik Gyula: Nagybányai Horthy Jenő és Kittenberger Kálmán: A megváltozott Afrika. 375 oldal, 109 képpel. Budapest, 1930. Franklin Társulat kiadása. [Book review.] . 196-197

Soós Lajos: Zimmermann Ágoston: Fejlődéstan. A Magyar Szemle Kincsestára. 43. sz. Budapest, 1930. 1-79 old.. [Book review.] 197-198

Dudich Endre: Zalányi, B.: Morpho-systematische Studien über fossile Muschelkrebse. (Geologica Hungarica. Series palaeontologica, Fasc. 5. 1929. pp. 152, 4 fénynyomatú tábla és 55 szövegrajz. A M. Kir. Földtani Intézet kiadása). [Book review.] ..... 198-199

Magyarországi folyóiratszemle. [Review of Hungarian periodicals.] 199-203

Zimmermann Ágoston: Dr. Abonyi Sándor. 1880-1930. [In memoriam Dr . Sándor Abonyi. 1880-1930.] 203-208

Fejérváry Géza Gyula: Bolkay. (1887 március 29 - 1930 augusztus 17).[In memoriam István Bolkay.] 208-211

Szalay László: Szakosztályunk ülései. [Sessions of our section.] $211-216$ 


\section{8. kötet - 1931}

1. füzet:

Dudich Endre: A barlangok biologiai kutatásáról. (Über die biologische Erforschung der Höhlen.) $1-23$

Wagner János: Anatomiai vizsgálatok Limacidákon. (Anatomische Untersuchungen an Limaciden.) 24-34

Wolsky Sándor: Az édesvizi ászka (Asellus aquaticus L.) második maxillájának érzékszerveiröl. (The sense organs of the second maxilla of Asellus aquaticus.) $35-40$

Mikszáth Gyula: Adatok a Börzsönyi-hegység és a Nagyszál Mollusca-faunájának ismeretéhez. (Beiträge zur Molluskenfauna des Börzsönyer-Gebirges und des Nagyszálberges.) ............................................................................... 41-49

Vásárhelyi István: Felsőméra emlősfaunája. (Die Säugetierfauna von Felsőméra.) ... 49-54

Dorning Henrik: Lovassy Sándor: Az Ecsedi-láp és madárvilága fennállása utolsó évtizedeiben. 86 oldal, 1 térképpel. Budapest, 1931. A Magyar Tudományos Akadémia kiadása. [Book review.] $54-55$

Dudich Endre: Kadocsa Gyula: Gazdasági állattan. Budapest, "Pátria" kiadása, 1929. 162 oldal, 50 szövegképpel. [Book review.] $55-56$

Soós Lajos: Wells H. G., Huxley Julian és Wells G. Ph.: Az élet csodái. Fordította Lambrecht Kálmán. 3 kötet, 1-1051 oldal. (Budapest, 1930). Pantheon kiadás. [Book review.] $56-57$

Dudich Endre: Dr. Maucha Rezső: Winkler Lajos vízvizsgáló módszereinek alkalmazása a limnologiában. Budapest, Országos Halászati Egyesület, 1930. pp. 247, 19 ábra. [Book review.] $57-58$

Soós Lajos: Boone, Lee: Crustacea: Anomura, Macrura. Schizopoda, Isopoda, Amphipoda, Mysidacea, Cirripedia and Copepoda. Bulletin of the Vanderbilt Marine Museum. Vol. III. Huntington, 1930. [Book review.] 59

Wagner János: Thiele, Johannes: Handbuch der systematischen Weichtierkunde. Erste Teil. Mit 470 Abbildungen im Text. Jena, Verlag von Gustav Fischer, 1929. (1-376 oldal). [Book review.] 59-60

Wagner János: Mermod, G.: Gastéropodes. (Cat. Inverteb. Suisse, fasc. 18) Mus. d'Hist. Nat. Geneve, 1930. Avec 87 figures dans le text. [Book review.] .......................... 60-61

Szalay László: Pax, F. und W. Arndt: Die Rohstoffe des Tierreichs. Berlin, 1928. Borntraeger. [Book review.] .............................................................................. 61-62

Szalay László: Szakosztályunk ülései. [Sessions of our section.] ............................... 63-64

2. füzet:

Zimmermann Ágoston: Az os penisről és az erectióról. (Über das Os penis und über die Erektion.) $65-72$

Kormos Tivadar: A Forestbed-fauna első nyomai Dalmáciában. (Die ersten Spuren einer Forestbed-Fauna in Dalmatien.) $72-79$ 
Wagner János: Újabb adatok a Daudebardiák életmódjának ismeretéhez. (Neue Beiträge zur Kenntnis von Daudebardia.) 79-91

Vasvári Miklós: A kis héja erdélyi előfordulása. (Das Vorkommen des Zwerghabichts in Siebenbürgen.) 91-102

Éhik Gyula: Nassonov, N.: Distribution géographique des moutons sauvages du monde ancien. Petrograd, 1923. 245 oldal, 19 tábla rajzzal, 1 térképpel és 65 szövegközötti ábrával. [Book review.] $103-108$

Pongrácz Sándor: Osborn, H. F.: Ursprung und Entwicklung des Lebens. Mit 135 Abbildungen. Stuttgart, 1930. [Book review.] 108-109

Szalay László: Molisch, Hans: A felkelő nap országában. Fordította Rapaics Rajmund. VIII + 464 oldal, 195 szövegközti képpel. Budapest, 1930. Kiadja a Kir. Magy. Természettudományi Társulat. [Book review.] 110

Varga Lajos: Buchner, Paul: Tier und Pflanze in Symbiose. Berlin, 1930. G. Borntraeger. II. kiadása a "Tier- und Pflanze in intracellularer Symbiose" c. műnek. 336 ábra, XX + 900 lap. [Book review.] $111-112$

Varga Lajos: Brehm, V.: Einführung in die Limnologie. (Schoenichen, Biologische Studienbücher, X. kötet). 88 ábra, VI + 261 old. 1930, Springer. [Book review.] $112-113$

Wagner János: Germain, L.: Mollusques terrestres et fluviatiles. (Premiere partie). Avec 13 planches et 470 figures. Faune de France, 21. Paris, P. Lechevalier, 1930. (477 + VIII oldal). [Book review.] $113-114$

Dudich Endre: Entz Géza és Soós Lajos: Élet a tengerben. (Királyi Magyar Természettudományi Társulat, Természettudományi Könyvkiadóvállalat, XCIX. kötet. Budapest, 1931. 484 oldal, 26 táblával és 112 szövegrajzzal). [Book review.] 114-116

Kittenberger Kálmán: Széljegyzetek Cholnoky Jenő "Afrika" c. könyvének "C). Állatvilág"

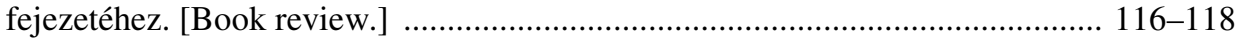

Nagy Jenő: Válasz dr. Szilády Zoltánnak. [Antwort to dr. Zoltán Szilády.] ............ 118-119

Szalay László: Szakosztályunk ülései. [Sessions of our section.] $119-122$

3-4. füzet:

Lambrecht Kálmán: Louis Dollo. 1857 december 7 - 1931 április 19. (In memoriam Louis Dollo.) 123-131

Varga Lajos: Katasztrófák a Fertö-tó életében. (Katastrophale Erscheinungen im Leben des Fertő (Neusiedler-See).) $132-147$

Maier István: A barlangi medve (Ursus spelaeus Ros.) állandó fogazata. (Das definitive Gebiss des Höhlenbären.) $147-170$

Kolosváry Gábor: A tarka vadászó kaszáspók (Zacheus variegatus Lendl) párosodása. (Über die Paarung des Zacheus variegatus Lendl.) $171-178$

Soós Lajos: Dudich, E.: Systematische und biologische Untersuchungen über die Kalkenlagerungen des Crustaceenpanzers in polarisiertem Lichte. Zoologica, 30. Bd., 5-6 Lief. Stuttgart, 1931. 154 lap, 14 táblával és 27 szövegképpel; Dudich, E.: Die Biologie der aggteleker Tropfsteinhöhle Baradla in Ungarn. Speleologische 
Monographien, 13. Bd. Wien, 1932. Speleologisches Institut kiadása. X+246 lap, 18 táblával és 22 szövegképpel. [Book review.] $178-181$

Dudich Endre: Zólyomi Bálint: A Bükkhegység környékének Sphagnum-lápjai. (Botanikai Közlemények, XXVIII., 1931.p. 89-121). [Book review.]

Dudich Endre: Manninger Rezső és Kotlán Sándor: A szárnyas baromfi fertőző és parasitás betegségei. Budapest, 1931. Stádium kiadása. 372 oldal, 2 színes melléklettel és 186 szövegképpel. [Book review.] 181-182

Dudich Endre: Rinne, Friedrich: Grenzfragen des Lebens. Eine Umschau im Zwischengebiet der biologischen und anorganischen Naturwissenschaft. Leipzig, 1931. Quelle \& Meyer. pp. 128, 119 képpel és 6 táblával. [Book review.] $182-183$

Dudich Endre: Das Lebensproblem im Lichte der modernen Forschung. Unter Mitarbeit von O. Kestner, L. Rhumbler, J. von Uexküll, L. Weickmann, P. Mildner, G. Wolff, R. Woltereck. Leipzig, 1931. Quelle \& Meyer, pp. 472, 22 ábra. [Book review.] 183

Dudich Endre: Fejérváry, G. J.: Nachbemerkungen zu meinem phylogenetischmechanistischen Erklärungsversuch der Morphologie des "klassischen" Menschenfusses. (Verh. zool.-bot. Ges. Wien, LXXX., 1930. p. 139-163). [Book review.] 183-184

Dudich Endre: Méhely Lajos: A rákok ősveséje. (Studia zoologica, I. 4. 1931. p. 261-275) Die Urniere der Crustaceen. (L. c., p. 276-291, 2 táblával és 3 szövegrajzzal). [Book review.] 184-185

Dudich Endre: Abel, O. und G. Kyrle: Die Drachenhöhle bei Mixnitz. Speläobiologische Monographien, VII-IX., 1930-31. [Book review.]

Béres Tibor: Dubois, Eug.: Die phylogenetische Grosshirnzunahme autonome Vervollkommnung der animalischen Funktionen. Biol. Gener., VI., 1930. p. 247-292, Taf. XXXIII. [Book review.] 185-189

Nagy Jenő: Schenk Jakab: A madarak világának tanulmányozása. Magyar Szemle Társaság kiadása. Budapest, (1931). [Book review.] 189-190

Dudich Endre: Szalai T.: Bionomische und methodologisch-systematische Untersuchungen an rezenten und fossilen Testudinaten. (Palaeobiologica, III., 1930. p. 347-364) 4 táblával és 1 szövegrajzzal. [Book review.] 190

Gelei József: Hartmann, M.: Praktikum der Protozoologie. 5-te erweiterte Auflage. Zweiter Teil von Kieszkalt und Hartmann: Praktikum der Bakteriologie und Protozoologie. S. IVI und 1-181, 136 Textfig. Jena, 1928. G. Fischer. [Book review.] 190-191

Gelei József: Kükenthal-Matthes: Leitfaden für das zoologische Praktikum. 10. Aufl. Jena, 1931. G. Fischer. [Book review.]

Gelei József: Kühn, A.: Grundriss der allgemeinen Zoologie. S. I-VI und 1-264. 214 Textfig. 4. verbesserte und erweiterte Auflage. Leipzig, 1931. G. Thieme. [Book review.] 191

Soós Lajos: Behyna Miklós: Az akvárium berendezése és gondozása. 98 képpel. Kiadta a Kir. Magyar Természettudományi Társulat. Budapest, 1931. [Book review.] ... 191-192

Cholnoky Jenő: Válasz Kittenberger Kálmán "széljegyzeteire". [Answer to Kálmán Kittenberger's ,notes”.] 192-194 
Kittenberger Kálmán: Viszonválasz Cholnoky Jenő válaszára. [Reply to Jenő Cholnoky.] 194-195

Magyarországi folyóiratszemle. [Review of Hungarian periodicals.]

$195-197$

Csiki Ernő: Bíró Lajos (1856-1931). [In memporiam Lajos Bíró (1856-1931).] .... 197-200

Szalay László: Szakosztályunk ülései. [Sessions of our section.] 200-202

\section{9. kötet - 1932}

1-2. füzet:

Dudich Endre: A parti ászka mésztartaléktestjei és a Zenker-féle szerv. (Die Kalkreservekörper von Hyloniscus riparius und das Zenker'sehe Organ.) .............. 1-15

Szalay László: Adatok az Aggteleki barlang Arachnoidea-faunájának ismeretéhez. (Beiträge zur Kenntnis der Arachnoideenfauna der Aggteleker Höhle.) 15-33

Stiller Jolán: A Tihany-környéki Peritrichák különös tekintettel az ökológiai viszonyokra. (Die Peritricheen von Tihany und Umgebung mit besonderer Berücksichtigung der ökologischen Verhältnisse.) $33-42$

Gebhardt Antal: Ökologiai és faunisztikai vizsgálatok a Zenoga medencében. (Ökologische und faunistische Untersuchungen im Zenoga-Bekken.) 42-59

Varga Lajos: Adatok a hazai mocsári teknős (Emys orbicularis) parazitái ismeretéhez. (Beiträge zur Kenntnis der Parasiten von Emys orbicularis.) $60-63$

Soós Lajos: A püspökfürdői pliocén Mollusca-faunáról. (On the Pliocene Mollusc Fauna of Püspökfürdő.) 64-72

Vásárhelyi István: Sündisznó vagy sünkutya?. (Schweinsigel oder Hundsigel.) $72-75$

Vásárhelyi István: A földikutya (Spalax hungaricus Nehrg.) abaujtornamegyei elöfordulása. (Über das Vorkommen von Spalax hungaricus Nehrg. im Komitate Abauj.) ... 75-77

Éhik Gyula: Jogosult-e a sünkutya és sündisznó elnevezés? (Über die Berechtigung des Namens „Hundsigel" und „Schweinsigel".) $78-83$

Soós Lajos: Rotarides Mihály: A lösz csigafaunája, összevetve a mai faunával, különös tekintettel a szegedvidéki löszökre. (137 képpel). A Szegedi Alföldkutató Bizottság Könyvtára. VI. szakosztály - A. Állattani Közlemények: 8. szám. 180 old. Szeged, 1931. [Book review.] $83-85$

Soós Lajos: Hesse, Paul: Zur Anatomie und Systematik palaearktischer Stylommatophoren. S. 1-118, mit 14 Tafeln. (Zoologica, 31. Bd., 1-2 Lieferung. Stuttgart, 1931). [Book review.] $85-86$

Dudich Endre: A magyar halászat összefoglaló ismertetése, szerepe és jövője a mezőgazdasági termelésben és a vízgazdálkodásban. Szerkesztette Fischer Frigyes. A m. kir. földmívelésügyi minisztérium kiadványai. 3. sz. Budapest, 1931. Pátria. pp. XXIV+224, 83 szövegábrával, 133 képpel 64 táblán és 1 színes mümelléklettel. [Book review.] $86-87$ 
Kormos Tivadar: Jacobi, Arnold: Das Rentier. (Ergänzungsband zum Zoologischen Anzeiger, Band 96, 1931. 1-264 lapon, 32 szövegképpel és 6 táblával). [Book review.]

Szalay László: Szilády Zoltán: Bulgária. Budapest, 1931. 1-472 oldal, 330 képpel, 3 színes képpel, 17 mülappal, 2 térképpel. Szerző kiadása. [Book review.] 88

Szalay László: Valter László: A mikroszkóp és kezelése. Népszerü természettudományi könyvtár 11. Kiadta a Kir. Magyar Természettudományi Társulat. Budapest, 1931. 1255 oldal, 116 rajzzal. [Book review.] 89

Pongrácz Sándor: Abel, O.: Die Stellung des Menschen im Rahmen der Wirbeltiere. Verl. G. Fischer. Jena, 1931. 276 képpel. 390 lap. [Book review.] 89-91

Pongrácz Sándor: Watson, J. B.: Behaviorism. New-York, 1930. 308 1.. [Book review.] 91-93

Szilády Zoltán: Válasz dr. Nagy Jenőnek. [Answer to dr. Jenő Nagy.] ........................... 93 Wagner János: Magyarországi folyóiratszemle. [Review of Hungarian periodicals.] . 93-96 Szalay László: Szakosztályunk ülései. [Sessions of our section.] 96-100

3-4. füzet:

Zimmermann Ágoston: A májonkívüli epeutak összehasonlító anatómiájához. (Zur vergleichenden Anatomie der exirahepalischen Gallenwege.) $101-116$

Wagner János: Tanulmányok ragadozó tüdőscsigákon. (Studien an Raublungenschnecken.) 117-125

Zimmermann Gusztáv: A Waldeyer féle lymphás torokgyürüröl (anulus lymphaceus Waldeyeri). (Über den Waldeyer'schen lymphatischen Rachenring.) 126-137

Éhik Gyula: Néhány adat a hazai görények és nyércek ismeretéhez. (Einige Beiträge zur Kenntnis der ungarischen Iltisse und Nörze.) $138-143$

Beke Ödön: Magyar hal- és madárnevek származása. (Über die Herkunft ungarischer Fischund Vogelnamen.) 143-151

Rotarides Mihály: A puhatestüek külső alakjának környezettani jelentősége. (Das ökologische Formproblem der Weichtiere.) $151-164$

Vásárhelyi István: Jászberény és környékének emlősfaunája. (Die Säugetierfauna von Jászberény und Umgegend.) $164-168$

Varga Lajos: Új Rotatoriák hazánk faunájában. (Neue Rotatorien in der Fauna Ungarns.) $168-184$

Gelei József: Miért fecskendez a festékkagyló? (Warum die Malermuscheln spritzen?) 184-191

Szilády Zoltán: A párisi V. rovartani világkongresszus. [The $5^{\text {th }}$ World Congress of Entomology in Paris.] 191-192

Parazita-faunánk új adatai. [New data to the Hungarian parasite-fauna. (Literature review).] 192

A szuronyos légy járványtani jelentősége. [The epidemic importance of the stable fly. (Literature review).] 193 
Pongrácz Sándor: Franz, V.: Systematik und Phylogenie der Wirbeltiere. (Handbuch der vergleichenden Anatomie. 1931. Bd. I. 185-268 1.). [Book review.] 193-196

Varga Lajos: Lenz, Friedrich: Lebensraum und Lebensgemeinschaft. Mathematischnaturwissenschaftlich-technische Bücherei, 27. kötet. Frankfurt a. M., Berlin, 1931. O. Salle, 36 rajz, 183 lap. [Book review.] 196-197

Rotarides Mihály: Baecker, Richard: Die Mikromorphologie von Helix pomatia und einigen anderen Stylommatophoren. (Ergebn. d. Anat. u. Entwicklungsgesch., 29. kötet, 1932. 449-585 oldal, 77 szövegkép). [Book review.] 197-198

Wagner János: Szunyoghy, Johann von: Beiträge zur vergleichenden Formenlehre des Colubridenschädels, nebst einer kraniologischen Synopsis der fossilen Schlangen Ungarns. Mit nomenklatorischen, systamatischen und phyletischen Bemerkungen. Mit Tafel I-VII und 116 Textfiguren. (Acta Zoologica, XIII., 1932, Stockholm. p. 1-56). [Book review.] 198

Gelei József: Kahl, A.: Urtiere oder Protozoa, I. Wimpertiere oder Ciliata (Infusoria). Eine Bearbeitung der freilebenden und ectocommensalen Infusorien der Erde, unter Ausschluss der marinen Tintinnidae. In: Die Tierwelt Deutschlands und den angrenzenden Meeresteile. 18. Teil, 12 RM. 21. Teil 14 RM. und 25. Teil, 17 RM. Jena, Gustav Fischer, 1930-1932. [Book review.] 198-199

Nagy Jenő: Végső válaszom dr. Szilády Zoltánnak. [Final answer to Dr. Zoltán Szilády.] 199

Pongrácz Sándor: Dr. báró Fejérváry Géza. 1894-1932. [In memoriam Dr. baron Géza Fejérváry. 1894-1932.] 199-204

Szalay László: Szakosztályunk ülései. [Sessions of our section.] $205-210$

\section{0. kötet - 1933}

\section{1-2. füzet:}

Gaál István: A fajok kihalása. (Das Aussterben der Arten.) $1-11$

Soós Lajos: Malakofaunisztikai adatok a Dunántúlról. (Contributions to the molluscan fauna of the trans-Danubian district of Hungary.) $12-26$

Wolsky Sándor: A szárazföldi Isopodák állítólagos hydrotaxisáról. (On the so-called hydrotaxis of terrestrial Isopoda.) 26-35

Gebhardt Antal: Az abaligeti és a mánfai barlang állatvilágának összehasonlítása. (Vergleichung der Tierwelt der Abaligeter- und Mánfaer Höhlen.) $36-44$

Kormos Tivadar: Baranomys Lóczyi n. g. n. sp. ein neues Nagetier aus dem Oberpliocän Ungarns = Baranomys Lóczyi n. g. n. sp., új rágcsáló a magyarországi felső pliocénből. (Baranomys Lóczyi n. g. n. sp ein neues Nagetier aus dem Oberpliocän Ungarns.) 45-54

Ábrahám Ambrus - Mödlinger Gusztáv: Az alpesi planária előfordulása a Pilis-hegységben. (Das Vorkommen von Planaria alpina im Pilis-Gebirge.) 54-59 
Varga Lajos: A lesenceistvándi tőzegláp néhány kerekesférgéről. (Über einige Rotatorien des lesenceistvánder Torfmoores.) 59-63

Ábrahám Ambrus: Adatok az édesvizi csontoshalak fali dúcsejtjeinek ismeretéhez. (Beiträge zur Kenntnis der Darmwandganglienzellen der Knochenfische.) 63-79

Szilády Zoltán: Aranyzöld legyeink megkülönböztetése. (Zur Unterscheindung unserer goldgrünen Fliegen.) 79-82

Soós Lajos: A Tacheopsis-nemröl. (Note on Tacheopsis.) 83-93

Varga Lajos: A Rhinoglena frontalis első hazai gyüjtője. [The first Hungarian collector of Rhinoglena frontalis.] 93-94

Sághy Ferencz: Válasz dr. Szilády Zoltánnak az "Állattani Közlemények" XXIX. kötet 3-4. füzetében megjelent (1932. dec. 15.) referátumára. [Answer to dr. Zoltán Szilády on his review published in Állattani Közlemények, XXIX. kötet 3-4. (1932. dec. 15.)] ........ 94

Szilády Zoltán: Válasz dr. Sághy Ferenc megjegyzéseire. [Answer to dr. Ferenc Sághy’s remarks.]

Sághy Ferencz: Utolsó válaszom dr. Szilády Zoltán megjegyzéseire. [Final answer to dr. Zoltán Szilády’s remarks.]

Szilády Zoltán: Utolsó szavam. [Sághy Ferencz válaszára]. [My last word. (On Ferenc Sághy's answer.)]

Soós Lajos: Ludwig, Wilhelm: Das Rechts-Links Problem im Tierreich und beim Menschen. Mit 143 Abbildungen. Berlin, 1932. Springer. [Book review.] 96

Szalay László: Naumann, E.: Grundzüge der regionalen Limnologie. (Thienemann, A.: Die Binnengewässer, XI. kötet). 8 táblázat és 31 ábra. XIV + 176 oldal. 1932. Stuttgart, Schweizerbart. [Book review.] 97-98

Dudich Endre: Maucha, R.: Hydrochemische Methoden in der Limnologie mit besonderer Berücksichtigung der Verfahren von L. W. Winkler. (Die Binnengewässer, XII.) Stuttgart, Schweizerbart, 1932. pp. 173, 36 ábrával 4 táblán és a szövegben 19 táblázattal. [Book review.] 98

Soós Lajos: Robson, G. C.: A Monograph of the Recent Cephalopoda. Part I. Octopodinae. London, 1929. pp. 236 és 7 tábla; Part II. The Octopoda (excluding the Octopodinae). London, 1932. pp. 359 és 6 tábla. Kiadja a British Museum. [Book review.] ........ 98-99

Wagner János: XI. Congresso Internazionale di Zoologia: Atti. (Archivio Zoologico Italiano, XVI. Padova, 1932, 3 kötet. p. 1-150 + 1-1508 + I-XXXVIII tábla). [Book review.] 99-100

Pongrácz Sándor: Stempell, W.: Die unsichtbare Strahlung der Lebewesen. Jena, 1932. Fischer. [Book review.] 100-103

Soós Lajos: Broom, Robert: The Mammal-like Reptiles of South Africa and the Origin of Mammals. London, 1932. pp. XVI+376. [Book review.] 103

Szalay László: Szakosztályunk ülései. [Sessions of our section.] 104-108 
3-4. füzet:

Zimmermann Ágoston: A térdtájék íncsontjairól. (Über die Sesambeine der Kniegegend.) 109-119

Dudich Endre: Faunisztikai jegyzetek. (Negyedik közlemény). (Faunistische Mitteilungen.) 120-129

Rotarides Mihály: A Prosobranchiaták lábának szövettani felépítése. (Der histologische Aufbau des Prosobranchier-Fusses.) $130-146$

Zilahi-Sebess Géza: Vérszívó Chironomidáink. (Unsere blutsaugenden Chironomiden.) 146-151

Wagner János: Egy új Helicella-faj Magyarország faunájában. (Eine neue Helicella-Art in der Fauna Ungarns.) $151-159$

Lörincz Ferenc \& Szentkirályi Zsigmond: Phlebotomus macedonicus (Adler és Theodor, 1931) elöfordulása Magyarországon. (Adatok az európai Phlebotomus fajok meghatározásához.) (Das Vorkommen von Phlebotomus macedonicus (Adler und Theodor, 1931) in Ungarn.) $160-169$

Ábrahám Ambrus: Újabb adatok az idegvégtestek mellékrostjainak ismeretéhez. (Neuere Beiträge zur Kenntnis der Nebenfasern der Nervenend-körperchen.) $170-176$

Varga Lajos: Squatinella Geleii n. sp., egy új kerekesféreg-faj hazánk faunájában. (Squatinella Geleii n. sp., ein neues Rädertier aus Ungarn.) $177-186$

Kolosváry Gábor: Loeser, Johann Albrecht: Die psychologische Autonomie des organischen Handelns. (Die Psychologie des Emotialen. Tl. 1.). In Abhandl. zur theoretischen Biologie, Heft 30. Berlin, Verl. von Gebrüder Borntraeger, 1931. [Book review.] $186-188$

Éhik Gyula: Ecsedi István: Népies vadfogás és vadászat a debreceni határban és a Tiszántúlon. (A Déri Múzeum néprajzi osztályának ismeretterjesztő közleményei, 3. füzet. Debrecen, 1933. 145 oldal, 78 képpel, rövid német kivonattal). [Book review.] $188-189$

Wagner János: Három doktori értekezés. 1. Borzsák Sándor: A magyarországi denevérek hallócsontjainak ismertetése; 2. Báró Sólymosy László: A madárlép szövettani szerkezete; 3. Rásky Klára: Az Eupemphyx Nattereri (Fitz) Stdr. összehasonlító alaktana. [Book review.] $189-190$

Szalay László: Fejérváry, G. J. Freiherr von: Einführung in die Zoologie. Fragment des Werkes: Handbuch der gesamten Zoologie. 1 tábla, 114 oldal. Pécs, 1933. [Book review.] 190-191

Soós Lajos: McAtee, W. L.: Effectiveness in nature of the so-called protective adaptations in the animal kingdom, chiefly as illustrated by the food habits of nearctic birds. (Smithsonian Miscellaneous Collections, vol. 85, number 7. p 1-201. Washington, 1932). [Book review.] 191-193

Soós Lajos: Jekelius, Erich: Die Molluskenfauna der dazischen Stufe des Beckens von Brasov. (Memoriile Institutului Geologic al Romaniei, vol. II. 1932.). [Book review.] 193-194

Pongrácz Sándor: Lambrecht, Kálmán: Handbuch der Palaeornithologie. Berlin, 1933. Borntraeger. Mit 209 abbildungen 1-1024 1.. [Book review.] 194-195 
Pongrácz Sándor: Jollos, V.: Genetik und Evolutionsproblem. Verh. d. Deutsch. Zool. Ges., 1931. p. 252-295. [Book review.] 195-197

Pongrácz Sándor: Hankó Béla: A hajdani Alföld ősi állatvilága. (A Debreceni Tisza István Tudományos Társaság kiadványa. 1933. 1-83 1.). [Book review.] 197

Gelei József: Sewertzoff, A. N.: Monographische Gesetzmässigkeiten der Evolution. p. IXVI, 1-371, 24 Diagrammen. Jena, G. Fischer, 1931. [Book review.] 197-198

Szalay László: Szakosztályunk ülései. [Sessions of our section.] 198-202

\section{1. kötet - 1934}

1-2. füzet:

Soós Lajos: Magyarország állatföldrajzi felosztása. (The zoogeographical division of historic Hungary.) $1-25$

Zimmermann Gusztáv: A macska csontjairól. (Die Knochen der Katze.) 25-42

Mödlinger Gusztáv: Adatok az Isopodák szövettanához. (Beiträge zur Histologie der Isopoden.) 42-48

Wagner János: Malakologiai tanulmányok délolaszországi növénykertekben. (Malakologische Studien in einigen botanischen Gärten Süditaliens.) .................. 48-55

Balázsy János László: Nyirokérkészítmények előállításáról. (Über die Herstellung von Lymphgefässpraeparate.) $56-64$

Kormos Tivadar: Zur Frage der Abstammung eurasiatischer Hasen = Az euráziai nyulak származástani problémája. (Zur Frage der Abstammung eurasiatischer Hasen.) ... 65-78

Vásárhelyi István: Adatok a mogyorós pele életmódjának ismeretéhez. (Beiträge zur Kenntnis der Lebensweise der Haselmaus.) $78-84$

Vásárhelyi István: Lillafüred és környéke emlősfaunája. (Die Säugetierfauna von Lillafüred und Umgebung.) $85-88$

Éhik Gyula: A farkas (Canis lupus L.) peniscsontjáról. (Über den Penis Knochen des Wolfes (Canis lupus L.).) 88-91

Éhik Gyula: Adatok Erdély emlősfaunájához. (Beiträge zur Säugerfauna Siebenbürgens.)

Beke Ödön: A pocok név származása. [The origin of the name „pocok” (vole).] 91-95

Fehér Jenő: A méh és a piros szín. [The honey bee and the red colour.] .95

Beke Ödön: A sündisznó székely neve. [The Sekler name of the hedgehog.] 95-97

Wolsky Sándor: Az örökléstan és származástan kapcsolatának újabb irodalma. [The recen literature of the heritability and pylogeny. (Literature review).] 98-100

Wolsky Sándor: Carpenter G. D. H. and Ford E. B.: Mimicry. Methuen's Monographs on Biological Subjects. London, Methuen \& Co. 1933. X és 134 oldal, 2 ábrával. [Book review.] $100-101$ 
Wagner János: Coen Giorgio: Saggio di una sylloge Molluscorum Adriaticorum. Consiglio Nazionale delle ricerche R. Comitato Talassografico Italiano. Memoria CXCII. Venezia, 1933. p. I-VII + 1-186 (10 táblával). [Book review.] 101

Wagner János: Ehrmann P.: Mollusca (Weichtiere). In: Die Tierwelt Mitteleuropas. II. Band, I. Lief. Verlag von Quelle \& Meyer, Leipzig, 1933. p. 1-264, 147 szövegábrával és 13 táblán 148 fényképfelvétellel. [Book review.] 102

Varga Lajos: Naef A.: Phylogenie der Tiere. (Handbuch der Vererbungswissenschaft, Lief. 13.) Berlin, Borntraeger, 200 1., 77 rajz. [Book review.] 102-103

Varga Lajos: Mollison, Th.: Phylogenie des Menschen. (Handbuch der Vererbungswissenschaft, Lief. 18.) Berlin, Borntraeger, IV+104 1., 101 rajz. [Book review.] 103-104

Pongrácz Sándor: Naef A.: Die Vorstufen der Menschwerdung. Jena, 1933. Verlag G. Fischer. 232 old., 129 képpel. [Book review.] 104-106

Soós Lajos: Magyarországi folyóiratszemle. [Review of Hungarian periodicals.] .. 107-109

Szalay László: Szakosztályunk ülései. [Sessions of our section.] $109-114$

3-4. füzet:

Gelei József: A csillósvéglények (Ciliata) érzőszervecskéi. (Die sensorischen Organellen der Ciliaten.) $115-138$

Varga Lajos: Újabb adatok a Fertő-tó kerekesféreg-faunájának ismeretéhez. (Neuere Beiträge zur Kenntnis der Rotatiorien-Fauna des Neusiedlersees.) $139-150$

Wagner János: A Planina-barlang Mollusca-faunája. (Die Mollusken-Fauna der PlaninaHöhle.) $150-157$

Farkas Béla: Vizsgálatok a halak hallóképességéröl. I.. (Untersuchungen über Gehörsempfindungen bei Fischen I.) $157-179$

Horváth Géza: Állatföldrajzi vonatkozások a Keleti-Kárpátok és a Pireneusok között. (Relations zoogéographiques entre les Carpathes-Orientales et les Pyrénées.) .. 179-182

Soós Lajos: Az öcsi felsö-pontusi Mollusca-fauna. (The Upper Pontic molluscan fauna of Öcs.) $183-210$

Szilády Zoltán: A nyérc elterjedése az Északkeleti-Kárpátokban. [The distribution of the European mink in the NE Carpathians.] $210-211$

Soós Lajos: A Theodoxus transversalis a Tiszában. [The Theodoxus transversalis in the Tisza River.] 211

Pongrácz Sándor: A jégkori és tundramaradványok kérdéséhez. [On the topic of the Pleistocene tundra-remnants.] $211-213$

Soós Lajos: Magyarország állatföldrajzi felosztása. [Helyesbítő megjegyzés.] [Zoogeographic division of Hungary. (Correction.)] 213

Soós Árpád: A Tropidiscus carinatus Müll. magyarországi elterjedése. [The Hungarian distribution of Tropidiscus carinatus Müll..]

Pongrácz Sándor: Cuénot Lucien: La genese des especes animales. III. éd. Avec 162 gravures, pp. 801. Paris, 1932. [Book review.] 
Pongrácz Sándor: Glogner M.: Phylogenese und Geschwulstentstehung. Leipzig, 1934. A. Barth. pp. 1-37. [Book review.]

Pongrácz Sándor: Jelgersma G.: Das Gehirn der Wassersäugetiere. Leipzig, 1934. A. Barth. 238 o.. [Book review.]

Éhik Gyula: Hone E.: The present status of the muskox in arctic North America and Greenland. Special publication of the American Committee for International Wild Life Protection. No. 5. Cambridge, Mass., U. S. A. 1934. 87 oldal, 4 tábla képpel, 3 szövegközötti térképpel és 2 külön (egy színes) térképlappal. [Book review.] .. 218-219

Varga Lajos: Lehmann Ernst: Biologie im Leben der Gegenwart. München, 1933. Lehmann J. F. 266 lap. [Book review.] 219-220

Varga Lajos: Uexküll J. \& Kriszat G.: Streifzüge durch die Umwelten von Tieren und Menschen. Ein Bilderbuch unsichtbarer Welten. Verständliche Wissenschaft, 21. köt. Berlin, 1934. Springer. X+102 1., 59 részben színes képpel. [Book review.]

220-221

Wagner János: Éhik Gyula: Prémes állatok tenyésztése. Népszerü természettudományi könyvtár 17. Kiadja a Kir. Magy. Természettud. Társulat. Budapest, 1934. pp 1-192. 45 képpel. [Book review.] 221-222

Wagner János: Homonnay Nándor: Hazai madaraink alsó gégefőjének összehasonlító anatómiája. Bölcsészdoktori értekezés. Budapest, Légrády testvérek nyomdája. 1934. pp. 1-45, 3 táblával. [Book review.] 222-223

Vasvári Miklós: Madon P.: Les Rapaces d' Europe, leur régime, leurs relations avec l'agriculture et la chasse. Toulon, 1933. pp. 292. [Book review.] $223-224$

Éhik Gyula: Magyarországi folyóiratszemle. [Review of Hungarian periodicals.] .. 224-225

Szalay László: Szakosztályunk ülései. [Sessions of our section.] $225-228$

\section{2. kötet - 1935}

\section{1-2. füzet:}

Farkas Béla: Vizsgálatok a halak hallóképességéről. II.. (Untersuchungen über das Hörvermögen bei Fischen II.) $1-21$

Soós Árpád: Magyarországi Planorbis-félék ivarkészülékének alak- és szövettana. (Morphologie und Histologie des Geschlechtsapparates der ungarischen PlanorbisArten.) $21-46$

Ábrahám Ambrus: Az ember szájpadmandolájának beidegződése. (Adatok a szájpadmandola alak- és élettanához.) (Die Innervierung der Gaumentonsille des Menschen.) $47-59$

Éhik Gyula: Új földipocok Szlavóniából. (A new Pitymys from Slavonia.) 60

Kormos Tivadar: Die perlzähnige Spitzmaus (Sorex margaritodon Korm.) und das Anpassungsproblem = A gyöngyfogú cickány (Sorex margaritodon Korm.) és az alkalmazkodás problémája. (Die perlzähnige Spitzmaus (Sorex margaritodon K o r m.) und das Anpassungsproblem.) $61-79$ 
Kesselyák Adorján: A szemlencseregeneráció kiváltó tényezői. (Előzetes jelentés.) (Die Auslösungsfaktoren der Wolffschen Linsenregeneration.) $80-86$

Wagner János: Helicella (Helicella) spirula Ceglédről. [Helicella (Helicella) spirula from Cegléd.] $86-87$

Pongrácz Sándor: Gróf Széchenyi Zsigmond: Elefántország. Budapest, 1934. Dr. Vajna György kiadása. [Book review.] $87-88$

Éhik Gyula: Dr. Hankó Béla: A magyar ló eredete. Közlemények a debreceni Tisza István tudományegyetem állattani intézetéből. 23. szám. Debrecen, 1935. [Book review.] 88-89

Éhik Gyula: Pákozdy László és Kubacska Béla: A magyar baromfi és tojás termelésének s értékesítésének válsága és kivezető útjai. 180 oldal, 18 képpel és 16 táblázattal. Hódmezővásárhely, Erdei Sándor kiadása. [Book review.] 89-90

Wolsky Sándor: Huxley Julian S. and Beer G. R.: The Elements of Experimental Embryology. Cambridge, University Press, 1934. XIV és 514 oldal. [Book review.] 90-91

Soós Lajos: Hesse Paul: Zur Anatomie und Systematik palaearktischer Stylommatophoren. 2. Teil. S. 1-59, mit 9 Tafeln. Zoologica, 33. Bd., 1. Lief. Stuttgart, 1934. [Book review.]

Kleiner Endre: Walker James J.: The Natural History of the Oxford District. II. kiadás. London-Oxford, 1934. pp. 336 \& XXX. [Book review.]

Soós Lajos: Wolf B.: Animalium Cavernarum Catalogus. Pars I. Berlin, 1934. W. Junk. [Book review.] 91-92

Pongrácz Sándor: Gregory W. K.: The new anthropogeny: Twenty-five stages of vertebrate evolution, from silurian chordate to man. Science, 1933. No. 1985. [Book review.] 92-94

Pongrácz Sándor: Hartmann M.: Allgemeine Biologie. Jena, 1933. G. Fischer. 792 o.. [Book review.]

Szalay László: Szakosztályunk ülései. [Sessions of our section.] 95-98

3-4. füzet:

Entz Géza: Elnöki megnyitó. (Antrittsrede des Vorstandes.) 99-100

Varga Lajos: A Hanság limnologiai viszonyai, különös tekintettel kerekesféreg-faunájára. (Die limnologischen Verhältnisse des Hanság, mit besonderer Berücksichtigung seiner Rotatorien Fauna.) $101-118$

Tóth László: Az elevenszülő Aphidák barázdálódó osztódása. (Furchungsteilung der viviparen Aphiden.) $119-122$

Sebestyén Olga: A Dreissena polymorpha elszaporodása a Balatonban. (Dreissena polymorpha Pall. in Lake Balaton.) $123-126$

Soós Lajos \& Wagner János: Faunánk egy új Helicella-fajáról. (On a new Helicella species of our fauna.) 127-131 
Szabó Margit: Kóros elváltozások csigákon. (Pathologische Veränderungen bei den Schnecken.) $132-135$

Szilády Zoltán: A magyarországi bagócslegyek. (Die ungarischen Dasselfliegen.) 136-140

Szelényi Gusztáv: Egy új microhymenoptera hazánk faunájában. (Eine neue Microhymenoptere aus Ungarn.) $140-143$

Tóth László: A levéltetvek intracelluláris symbiózisa. (Über die intracellular Symbiose der Aphiden.) $143-151$

Kormos József: A Prodiscophrya collini (Root) ivari kétalakúsága és conjugatiója. (Geschlechtsdimorphismus und Conjugation bei Prodiscophrya Collini (Root).) 152-168

Wagner János: Újabb malakologiai adatok a Mátrából. (Neue malakologische Beiträge aus dem Mátra-Gebirge (Oberungarn).) $168-172$

Kesselyák Adorján: Adatok a Streptocephalus torvicornis Waga kerületi idegrendszerének ismeretéhez. (Beiträge zur Kenntnis des periferischen Nervensystems von Streptocephalus torvicornis Waga.) $172-184$

Szilády Zoltán: A kolumbácsi légy kérdéséhez. [To the question of the fly Simulia columbacensis.] 184

Pongrácz Sándor: A denevérszárnyú vagy rajnai kérész (Oligoneura rhenana Pict.) megjelenése hazánkban. [The appearance of the mayfly Oligoneura rhenana Pict. in Hungary.] 184-185

Wolsky Sándor: Greguss Pál: Bevezetés az örökléstanba. Budapest, Novák Rudolf és Társa kiadása. 1935. 1-222 oldal, 98 ábrával. [Book review.] $185-186$

Varga Lajos: Gerhardt Ulrich: Biologie der Fortpflanzung im Tierreiche. Verständliche Wissenschaft, 22. köt. 1934. Springer. VIII + 149 1., 47 rajz. [Book review.] ... 186-187

Varga Lajos: Hamacher J.: Biologie für Jedermann. Eine methodische erste Einführung in die Gesetze des Lebens für Naturfreunde und für den Unterricht. Handbücher für die praktische naturwissenschaftliche Arbeit. 24. köt. Stuttgart, 1934. Franckh, 117 lap, 3 színes tábla, 231 rajz. [Book review.] $187-188$

Varga Lajos: Thesing Curt: Schule der Biologie. München, C. H. Beck, 1934. XIV+391 lap. [Book review.] $188-189$

Varga Lajos: Négy doktori értekezés. 1. Balogh J. I.: A Sashegy pókfaunája. Faunisztikai, rendszertani és környezettani tanulmány. M. K. Pázmány P. Tudományegy. Állatrendszertani Intézet, Budapest, 1935. 60 old.; 2. Kalmár Z.: A madár mellcsont-taraja (crista sterni) és a repülés. Budapest, 1935. 26 1. 4 tábla; 3. Dr. Kleiner E.: A sárga billegető Magyarországon előforduló fajtái. M. K. Madártani Intézet, Budapest, 1934. 34 old.; 4. Meggyesi É.: Magyarország nappali pillangóinak elterjedése. Debrecen, 1935. 24 old.. [Book review.] $189-192$

Pongrácz Sándor: Abel O.: Vorzeitliche Lebensspuren. Jena, 1935. Fischer. 644 o., 530 rajzzal. [Book review.] 192-194

Pongrácz Sándor: Zeuner F.: Die Stammesgeschichten der Käfer. Palaeontologische Zeitschrift, 1933. 280-312 old.. [Book review.] 194-196 
Soós Lajos: Gebhardt Antal: Az abaligeti barlang élővilága. Mathematikai és Természettudományi Közlemények, XXXVII. kötet, 4. szám. Budapest, 1934. 1-264 oldal. [Book review.] 196-197

Magyarországi folyóiratszemle. [Review of Hungarian periodicals.] 197-199

Mödlinger Gusztáv: Szakosztályunk ülései. [Sessions of our section.] 199-202

\section{3. kötet - 1936}

\section{1-2. füzet:}

Gelei József: A csavarmentes vagy kochliooid alkattypus a csillósok (Ciliata) világában. (Ein geschraubter oder kochliooider Körperbau in der Ciliatenwelt.) ...................... 1-35

Zimmermann Ágoston: Adatok a juh gégeporcainak összehasonlító anatomiájához, különös tekintettel elcsontosodásukra. (Zur vergleichenden Anatomie der Kehlkopfknorpel beim Schaf.) $36-43$

Rotarides Mihály: Vizsgálatok átlátszóvá tett csigákon. (Examen anatomique des mollusques gastéropodes par le procédé des préparations transparentes.) 44-53

Soós Árpád: Magyarország mohában élő fonalférgeiről. I.. (Über die moosbewohnenden Nematoden Ungarns I.) 53-64

Lange Nándor: Adatok néhány édesvizi halunk hypophysisének alak- és élettani ismeretéhez. (Morphologisch-physiologische Untersuchungen an der Hypophyse von Fischen.) $65-83$

Apor László: Adatok a koponyatető varratainak ismeretéhez. (Beiträge zur Kenntnis der Schädeldachnähte.) 84-89

Zimmermann Ágoston: Zietzschmann O.: Handbuch der Anatomie des Hundes. Zweite, vollständig umgearbeitete Auflage der "Anatomie des Hundes" von Ellenberger und Baum. I. Band: Skelett- und Muskelsystem. Berlin, 1936. Verlag P. Parey. 250 oldal 180 képpel. [Book review.]

90

Szilády Zoltán: Gaál István: Amit rosszul tudunk. Természettudományi koholmányok és balitéletek. 1-438 1. Képekkel, évszám nélkül (1936). Egyetemi Nyomda. [Book review.] 90-92

Gaál István: Maderspach Viktor: Páreng - Retyezát. Vadászataim a Déli Kárpátokban. 1200 oldal. Budapest, 1935. [Book review.]

Pongrácz Sándor: Méhely Lajos: Az ősméhek természetrajza. Budapest, 1936. 1-216 old. 60 eredeti táblával. [Book review.] 92-94

Pongrácz Sándor: Simpson G.: The first mammals. Quarterly Review of Biology. 1935. 134-180 old.. [Book review.] 94-95

Pongrácz Sándor: Schmidt Hermann: Einführung in die Palaeontologie. Stuttgart, 1935. 253 old. 466 képpel. [Book review.] 95-96

Soós Lajos: Az esztergomi katolikus nyári egyetem kiadványai. I. Az 1934. évi előadások. Budapest, 1935. [Book review.] 96-98 
Soós Lajos: Lovrekovich István, Tomcsik József és Lőrincz Ferenc: Bakteriologia, immunitástan, parazitologia. 249 szövegközti ábrával és 2 színes táblával. A Magyar Orvosi Könyvkiadó Társulat kiadása. Budapest, 1935. 619 oldal. [Book review.] 99-102

Mödlinger Gusztáv: Szakosztályunk ülései. [Sessions of our section.]

3-4. füzet:

Soós Lajos: A magyarországi Melania-félék anatomiájához. I.. (Zur Anatomie der ungarischen Melaniiden I.) 103-134

Zimmermann Ágoston: A kétfejü combizom összehasonlító anatomiájához. (Zur vergleichenden Anatomie des zweiköpfigen Schenkelmuskels.) $134-142$

Kesselyák Adorján: Bars vármegye szárazföldi ászkarákjai. (Die Landasselfauna von Komitat Bars) $142-148$

Székessy Vilmos: Adatok a Tihanyi-félsziget xerotherm bogárfaunájának ismeretéhez. (Über die xerotherme Koleopterenfauna der Halbinsel Tihany.) 149-157

Zimmermann Ágoston: A nemzetközi anatomiai nomenklaturáról. (Über die internationale anatomische Nomenklatur.) $158-160$

Soós Árpád: A hőmérséklet ökológiai jelentősége a mohában élő fonalférgek életében. (Die Temperatur als ökologischer Faktor im Leben der moosbewohnenden Fadenwürmer.) $160-173$

Anghi Csaba Geyza: A zambezi-tigrisló Európa múzeumaiban. (Die Zambezi-Tigerpferde (Equus Burchelli zambeziensis Prazak) in den Museen Europas.) $173-180$

Pongrácz Sándor: Helyesbítések a magyar fauna jegyzékében. (Berichtigungen in der Enumeration der ungarischen Fauna.) $181-193$

Soós Lajos: A tatatóvárosi langyos vizek csigái. [The snails of the lukewarm waters at Tatatóváros.] 194-195

Varga Lajos: Hesse Richard und Doflein Franz: Tierbau und Tierleben in ihrem Zusammenhang betrachtet. I. kötet: Der Tierkörper als selbständiger Organismus. II. kiadás. Jena, 1935, Fischer. XII + 878 lap, 679 rajz:. [Book review.] 195-196

Varga Lajos: Rylov W. M.: Das Zooplankton der Binnengewässer. Einführung in die Systematik und Ökologie des tierischen Limnoplanktons mit besonderer Berücksichtigung der Gewässer Mitteleuropas. (Thienemann: Die Binnengewässer, XV. köt.). XI + 272 lap, 16 szövegköztiés 30 táblán 329 rajz. 1936. [Book review.] 196-197

Wagner János: Leidenfrost Gyula: Keserü tenger. A Magyar Földrajzi Társaság könyvtára. Budapest, 1936. 1-224 1., 56 képpel. [Book review.] 197-198

Warga Kálmán: Nagy Jenő: Az erdő madárvilága. Debrecen, 1936. 65 színes képpel és 26 rajzzal, 1-104 1.. [Book review.] 198-199

Gaál István: Amit a bíráló rosszul tud. (Válaszul Szilády Zoltán bírálatára). [What is not well known by the reviewer. (Antwort on Zoltán Szilády's review] 199-201

Krepuska Gyula: A magyar állattani irodalom 1935-ben. [The Hungarian zoological lirterature in 1935.] 201-212

Magyarországi folyóiratszemle. [Review of Hungarian periodicals.] $212-214$ 


\section{4. kötet - 1937}

\section{1-2. füzet:}

Varga Lajos \& Mika Ferenc: A pézsmapocok elterjedése Sopron környékén, adatokkal az állat életmódjának ismeretéhez. (Die Bisamratte (Ondatra zibethica Lac.) in der Umgebung von Sopron, nebst Beobachtungen über ihre Lebensweise.) ................ 1-13

Sebestyén Olga: Egy Dinoflagellata, a Gonyaulax apiculata (Penard) Entz betokozódásáról. (On the encystment of a Dinoflagellate: Gonyaulax apiculata (Penard) Entz.) ..... 13-21

Bánki László: A kék dongólégy (Calliphora erythrocephala Meig.) E-vitamin szükségletének kérdése, a légyfajra vonatkozó néhány biologiai megfigyeléssel. (Untersuchungen über den Vitamin E-Bedarf des blauen Brummers.) $21-42$

Soós Árpád: Magyarország mohában élő fonalférgeiről. II.. (Über die moosbewohnenden Nematoden Ungarns. II.) $42-46$

Soós Lajos: A magyarországi Melania-félék anatomiájához. II.. (Zur Anatomie der ungarischen Melaniiden. II.) ............................................................................. 46-59

Wagner János: Újabb adatok a Bükk-hegység Mollusca-faunájának ismeretéhez. (Neue Beiträge zur Kenntnis der Mollusken-Fauna des Bükk-Gebirges in Nordungarn.) 59-65

Wolsky Sándor: A szénmonoxid hatása a selyemlepke (Bombyx mori L.) nyugvó petéinek lélekzésére. (Előzetes közlemény.) (The effect of carbon monoxide on the respiration of resting eggs of the silkworm (Bombyx mori L.)) $65-70$

Ábrahám Ambrus: A békák szájpadnyálkahártyájának mikroszkópikus beidegződése. (Die mikroskopische Innervation der Gaumenschleimhaut von Fröschen.) ................... 71-80

Aczél Márton: Trypetida-tanulmányok. (Trypetiden Studien.) .................................. 80-82

Soós Árpád: Az Anisus septemgyratus rendszertani helye. (Die systematische Stellung von Anisus septemgyratus.) 83-87

Szilády Zoltán: Jegyzetek a Dipterák lábszerkezetéről. (Bemerkungen über den Bau der Dipterenbeine.) $87-92$

Varga Lajos: A Hydra-félék előfordulása hazánkban. [The Hydridae in Hungary.] 93

Varga Lajos: Hellmich Walter: Tiere der Alpen. München, 1936, Bruckmann. 4 színes tábla, 8 fényképtábla, 38 rajz, 126 1.. [Book review.] 93-94

Varga Lajos: Thesing Curt und Kurtz Rudolf: Sonderlinge des Lebens. Entdeckungsfahrt in eine rätselvolle Wunderwelt. Berlin, 1936. Drei Masken Verlag A. G. 204 lap. [Book review.] 94-95

Szalay László: Nadler Herbert: Vadásznapok, vadászévek. Elbeszélések és naplójegyzetek a szerző eredeti fényképfelvételeivel. Budapest, 1937. 1-279 oldal, 52 képpel. Dr. Vajna György és Társai kiadása. [Book review.] 
Szalay László: Leidenfrost Gyula: Kék Adria. Budapest (évszám nélkül). 311 oldal, 76 képpel. Kir. Magy. Egyetemi Nyomda kiadása. Magyar Könyvbarátok sorozat. [Book review.] 96-97

Kesselyák Adorján: Spemann Hans: Experimentelle Beiträge zu einer Theorie der Entwicklung. Berlin, 1936. Springer. Pp. I-VIII+1-296. RM 27. [Book review.] ....... 97

Pongrácz Sándor: Carrel Alexis: Man - the unknown. London. 298 1.. [Book review.] 97-99

Pongrácz Sándor: Kempermann Th.: Am Wendepunkt der Stammesgeschichte. Jena, 1936. 36 1.. [Book review.] 99-102

Pongrácz Sándor: Gregory W.: Williston's Law relating to the evolution of skull bones in the Vertebrates. Am. Journ. Phys. Anthr., 1935, 114-152 1.. [Book review.] .... 102-103

Pongrácz Sándor: Sátori József: Adatok a magyar tegzesszitakötő fauna ismeretéhez. A Tisza István Tudományegyetemi Állattani Intézet Közleményei, 1935. 25. sz. 1-20 1.. [Book review.] 103

Soós Árpád: Frenzel G.: Untersuchungen über die Tierwelt des Wiesenbodens. 1936, p. 1150. [Book review.] 103-104

Soós Lajos: Méhes Gyula: Budapest vidékének eocén ostracodái. A Geologica Hungarica palaeontologiai sorozatának 12. füzete. 1-64 old., 4 táblával és 63 szövegábrával. (Német nyelvü kivonat az 51-56. oldalon). Budapest, 1936. [Book review.]

Mödlinger Gusztáv: Szakosztályunk ülései. [Sessions of our section.] 104-108

3-4. füzet:

Rotarides Mihály: Konzerválástechnikai vizsgálatok halakon. (Recherches sur la conservation des poissons.) 109-121

Zimmermann Gusztáv: A házinyúl petefészektasakja. (Die Eierstockstasche (Bursa ovarii) des Kaninchens.) $121-129$

Kormos Tivadar: Újabb adatok a Prospalax-nem ismeretéhez. (Neue Beiträge zur Kenntnis der Gattung Prospalax.) $130-142$

Lukács Károly: Pontyjelölések a Balatonon. (Le marquage des Carpes dans le lac Balaton.) 142-151

Éhik Gyula: Újabb adat a nyest (Martes foina Erxl.) ivarzási idejének ismeretéhez. (Ein neuer Beitrag zur Frage der Brunstzeit beim Marder (Martes foina Erxl.).) ..... 151-156

Sebestyén Olga: A Balaton régi lakóinak küzdelme a vándorkagylóval. (The struggle of certain members of the original Balaton fauna and flora against Dreissena polymorpha Pall .) 157-164

Balogh János: Adatok Magyarország páncélosatka faunájának ismeretéhez. (Stud. Acar. 5.). (Beiträge zur Kenntnis der Moosmilben-Fauna von Ungarn.) 164-169

Homonnay Nándor: Anatomiai vizsgálatok a madarak vakbelén. (Anatomische Untersuchungen am Blinddarme der Vögel.) $170-185$

Szunyoghy János: Egy új Spalax Erdélyből. (Ein neuer Spalax aus Siebenbürgen.) 185-191 
Pongrácz Sándor: Beadnell C. M.: A Picture Book of Evolution. London, 1935. 3091 .. [Book review.]

Pongrácz Sándor: Seiffert W.: Die Erbgeschichte des Menschen. Stuttgart, 1935. 168 1. 108 képpel. [Book review.]

Pongrácz Sándor: Nachtwey R.: Wunderbare Welt im Wassertropfen. 1936. 45 képpel. 185 1.. [Book review.]

Szalay László: Beebe William: Félmérföldnyire a tenger színe alatt. Fordította Sebestyén Olga és Wolsky Sándor. I-VI+1-303 oldal. 28 táblán 36 képpel, két színes mümelléklettel és egy térképpel. Budapest, 1937. A Királyi Magyar Természettudományi Társulat kiadása. [Book review.] 194-196

Mödlinger Gusztáv: Wunder Wilhelm: Physiologie der Süsswasserfische Mitteleuropas. Handbuch der Binnenfischerei Mitteleuropas. II. B. kötet. Stuttgart, 1936. XI+340 lap, 1 színes és 9 fekete tábla, 213 szövegközti rajz. [Book review.] 196-197

Székessy Vilmos: Horn Walther und Kahle Ilse: Über entomologische Sammlungen, Entomologen und Entomo-Museologie. I-III. Entom. Beihefte aus Berlin-dahlem. Herasgegeb. v. d. Biolog. Reichsanstalt u. d. Deutschen Entomolog. Institut d. KaiserWilhelm-Gesellschaft. (I. 14.XII. 1935, II. 4. X. 1936, III. 1. VIII. 1937). 536 oldal, 38 tábla. [Book review.] 197-198

Rotarides Mihály: Ehrenbaum E.: Naturgeschichte und wirtschaftliche Bedeutung der Seefische Nordeuropas. Stuttgart, 1936. X. 338 oldal, a szövegben és 26 táblán 276 képpel. [Book review.] 198-199

Wagner János: Ökland F.: Die geographischen Rassen der extramarinen Wirbeltiere Europas. Zoogeographica, 1937. p. 389-484. [Book review.] 199-200

Soós Árpád: Szüts András: Az ép és kóros szövettani vizsgálat módszerei. Budapest, 1936. VIII+308 1., 16 szövegközti ábrával és 1 színes táblával. [Book review.] .......... 200-201

Kleiner Endre: Niethammer Günther: Handbuch der Deutschen Vogelkunde. I. Passeres. Leipzig, 1937. pp. 474, 1 színes tábla, 69 kép. [Book review.] 201

Méhes Gyula: Válasz Soós Lajosnak "Budapest vidékének eocén ostracodái" c. munkám ismertetésére. [Answer to Lajos Soós's review of my work „Eocene ostracods of Budapest".] 201-202

Krepuska Gyula: A magyar állattani irodalom 1936-ban. [The Hungarian zoological lirterature in 1936.] 202-212

Mödlinger Gusztáv: Szakosztályunk ülései. [Sessions of our section.] 212-214

\section{5. kötet - 1938}

\section{1-2. füzet:}

Lőrincz Ferenc \& Mihályi Ferenc: Vizsgálatok a légy-kérdés egészségügyi vonatkozásairól Magyarországon. (Untersuchungen über die hygienische Bedeutung der Fliegenfrage in Ungarn.) 1-13 
Woynárovich Elek: Limnológia tanulmányok a Horthy Miklós út melletti "Feneketlen tó"n. (Limnologische Untersuchungen in einem Teiche bei Budapest.) $13-42$

Varga Lajos: Barsmegye mohalakó kerekesférgei. (Moosbewohnende Rotatorien aus dem Komitate Bars.)

$42-51$

Sátori József: Adatok a Bükk-hegység rovarfaunájának ismeretéhez. (Beiträge zur Kenntnis der Insekten-Fauna des Bükk-Gebirges in Nordungarn.) $51-61$

Soós Árpád: A magyarországi tőzegmoha-lápok fonalférgeiről. I. (Die Nematoden der ungarischen Sphagnummoore I.) $61-83$

Dudich Endre: Az élettudomány belső tagozódása. (Die innere Gliederung der Biologie.) $83-90$

Szelényi Gusztáv: Új Macroteleia (Hymenoptera, Proctotrupoidea) Magyarországból. (A new species of Macroteleia Westw. (Hymenopt. Proctotrupoidea) from Hungary.) 91-94

Homonnay Nándor: A balkáni kacagó gerle (Streptopelia decaocto Friv.) előfordulása a Balaton mellett. [The occurrence of the Collared Dove (Streptopelia decaocto Friv.) at the Lake Balaton.] 94-95

Kesselyák Adorján: Szabó Zoltán: Az átöröklés. Az általános örökléstudomány elemei, figyelemmel a gazdasági és orvosi vonatkozásokra. Budapest, 1938. I-VII + 1-444 1. A Királyi Magyar Természettudományi Társulat kiadása. [Book review.] 95-97

Wolsky Sándor: Timoféeff-Ressovsky N. W.: Experimentelle Mutationsforschung in der Vererbungslehre. Wissenschaftliche Forschungsberichte, Naturwiss. Reihe, Bd. 42. Dresden u. Leipzig, 1937. 3 táblával, 52 szövegközti képpel és 40 táblázattal. [Book review.] 97-98

Balogh János: Petrusewicz K.: Badania ekologiczne nad krzyzakami (Argyopidae) na tle fizjografji Wilenszczyzny. (Ökologische Untersuchungen der Argyopidae und Physiographie der Wilnoer Gegend). Travaux de l'Institut de Zoologie, No. 40. Wilno, 1938. pp. 83. [Book review.]

Homonnay Nándor: Glasewald Konrad: Vogelschutz und Vogelhege. Neudamm, 1937. p.1-295, 106 ábrával. [Book review.] 99-100

Pongrácz Sándor: Boenig H.: Leitfaden der Entwicklungsgeschichte des Menschen. Leipzig, 1938. 261 1., 316 részben színes képpel. [Book review.] 100-101

Pongrácz Sándor: Zimmer K.: Strahlungen, Wesen, Erzeugung und Mechanismus der biologischen Wirkung. Leipzig, 1937. 72 1., 40 képpel. [Book review.] 101

Soós Lajos: Entz Géza, Kottász József és Sebestyén Olga: Quantitativ vizsgálatok a Balaton biosestonján. A Magyar Biologiai Kutatóintézet Munkái, IX. kötet, 1937. 1-152 1. (magyar szöveg 1-72 1.). [Book review.] $102-103$

Magyarországi folyóiratszemle. [Review of Hungarian periodicals.] $103-104$

Mödlinger Gusztáv: Szakosztályunk ülései. [Sessions of our section.] $104-110$

3-4. füzet:

Ábrahám Ambrus: A neurontan mai állása. (Der heutige Stand der Neuronenlehre.) 111-130 
Kormos József: A szívókások (Suctoria) szívócsöveinek szerkezete és müködése. (Bau und Funktion der Saugröhrchen der Suctorien.) $130-153$

Veress Elemér: Tanulmányok a meduzák ritmusos mozgásáról. (Studien über die rhythmischen Bewegungen der Medusen.) $153-170$

Aczél Márton: Adatok Barsmegye Muscida faunájához. (Beiträge zur Kenntniss des Muscidenfauna des Komitates Bars.) $170-175$

Lörincz Ferenc \& Mihályi Ferenc: Adatok a hazai malária-kérdés vizsgálatához. (Anopheles maculipennis tanulmányok.) (Beiträge zur Malariafrage in Ungarn. (Anopheles maculipennis-Studien.)) $176-186$

Pongrácz Sándor: Elnöki beköszöntő. (Antrittsrede des Präsidenten.) $187-191$

Rotarides Mihály: Arnold Joh. Paul und Ahl Ernst: Fremdländische Süsswasserfische. Beschreibung aller eingeführten Arten mit Angaben über ihre Haltung, Zucht und Pflege. Gustav Wenzel und Sohn, Braunschweig, (1936). 592 nyolcadrét oldal, 7 egyszínű tábla és 700-nál több szövegkép. [Book review.] 192

Rotarides Mihály: Norman J. R.: Illustrated guide to the Fish-Gallery. British Museum (Natural History). London, 1937. X+176 oldal, 100, részben táblákra nyomott képpel és egy színes táblával. [Book review.]

Rotarides Mihály: Illustriertes Fischerei-Lexikon. Herasgegeben unter Mitwirkung namhafter Fachleute. J. Neumann Verlag, Neudamm, 1936. VIII+362 oldal, 251 szövegképpel. [Book review.] 192-193

Magyarországi folyóiratszemle. [Review of Hungarian periodicals.] 193-194

Krepuska Gyula: A magyar állattani irodalom 1937-ben. [The Hungarian zoological lirterature in 1937.] 194-204

Mödlinger Gusztáv: Szakosztályunk ülései. [Sessions of our section.] $205-210$

\section{6. kötet - 1939}

1-2. füzet:

Varga Lajos \& Dudich Endre: Barsmegyei kerekesférgek. (Rotatorien aus dem Komitate Bars) $1-28$

Zimmermann Ágoston: Adatok az izompólyák összehasonlító anatómiájához. (Zur vergleichenden Anatomie der Fascien.) $28-38$

Homonnay Nándor: A Balaton-melléki biotopok kialakulásának jelentősége a vízi madarak megtelepedése szempontjából. (Über die Bedeutung der Ausbildung der Biotope in der Umgebung des Balaton-Sees für die Ansiedlung der Wasservögel.) $38-53$

Zimmermann Gusztáv: Adatok a juh hasüregének tájanatomiájához. (Beiträge zur topographischen Anatomie der Bauchhöhle des Schafes.) 53-61

Horváth János: Mikrooperációs kísérletek a magdimorphismus élettani jelentőségének megvilágítására. (Mikrooperations-Versuche zur Aufklärung der physiologischen Bedeutung des Kerndimorphismus.) $62-82$ 
Sátori József: Új tegzes-faj (Trichoptera) Magyarországon. (Eine neue Trichopteren-Art aus Ungarn.)

Pongrácz Sándor: Schindewolf H. O.: Fortschritte der Palaeontologie. 1938. 371 1.. [Book review.] 86-89

Pongrácz Sándor: Winton F. R. and Bayliss L. E.: Human physiology. II. ed. London, 1937. 627 1., 227 képpel. [Book review.]

Varga Lajos: Koller Gottfried: Hormone bei wirbellosen Tieren. Probleme der Biologie. I. Bd. Leipzig, 1938. Akad. Verlagsges. VIII+143 old.. [Book review.] 90-91

Varga Lajos: Goetsch Wilhelm: Die Staaten der Ameisen. Verständliche Wissenschaft. 33. Bd. Berlin, 1937. Springer. VII+159 1.. [Book review.]

Soós Lajos: Behyna Miklós: Az akvárium élővilága és gondozása. 2. bővített és átdolgozott kiadás. Budapest, 1938. A K. M. Természettudományi Társulat kiadása. [Book review.] 91-92

Soós Árpád: Magyarországi folyóiratszemle. [Review of Hungarian periodicals.] .... 92-94

Mödlinger Gusztáv: Szakosztályunk ülései. [Sessions of our section.] 94-96

3-4. füzet:

Ábrahám Ambrus: A békák bőrének mikroszkópikus beidegzése. (Die mikroskopische Innervation der Froschhaut.) 98-107

Mihályi Ferenc: A szúnyog elleni védekezés entomologiai előkészítése Hévizen. (Entomologische Vorarbeiten zur Bekämpfung der Stechmükkenplage in Héviz.) 107-117

Vásárhelyi István: Adatok a Bükk denevérfaunájához. (Beiträge zur Kenntnis der Fledermaus-Fauna des Bükk-Gebirges.) $117-123$

Kleiner Endre: Madártani megfigyelések Dél-Franciaországban. (Ornithologische Beobachtungen in Südfrankreich.) $123-130$

Jaczó Imre: Alaktani, biometriai és életmódtani vizsgálatok egy Thuricolán (Ciliata, Peritricha). (Morphologische, biometrische und biologische Untersuchungen an einer Thuricola-Art (Ciliata, Peritricha).) $130-147$

Anghi Csaba Geyza: A tigrislovak részleges albinizmusa, csíkozatcsökkenése és az ú. n. Ward-typus. (Über den partiellen Albinismus bei Tigerpferden, die Streifenreduktion und den sogen. Ward-Typus.) $147-155$

Sátori József: Adatok a Bükk és a Mátra rovarfaunájához. (Beiträge zur Insekten-Fauna des Bükk- und Mátra-Gebirges in Nordungarn.) $156-168$

Klie, Walter: Beiträge zur Kenntnis der Ostrakodenfauna Ungarns = Adatok Magyarország kagylósrák-faunájának ismeretéhez. (Beiträge zur Kenntnis der Ostrakodenfauna Ungarns) $168-174$

Wagner János: A Hygromia cinctella Drap. újabb budapesti előfordulásai. [New records of Hygromia cinctella Drap. from Budapest.] 174-175 
Soós Lajos: Huxley Julian and Koch Ludwig: Animal language. Described by Julian Huxley, recorded by Ludwig Koch and the Parlophon Co. Photographed by Ylla. London, 1938. Country Life Ltd. Pgg. 50. [Book review.] $175-176$

Varga Lajos: Győrfi János: Adatok a fürkészdarazsak erdészeti jelentőségéhez. Doktori értekezés. Készült a M. Kir. József Nádor Müszaki és Gazdaságtudományi Egyetem Erdővédelmi Tanszéken. Sopron, 1930. 121 lap, 16 ábrával. [Book review.] ....... 176-177

Varga Lajos: Jacobs Werner: Fliegen, Schwimmen, Schweben. Verständliche Wissenschaft, 36. köt. IV+134 1., 86 ábrával. Berlin, 1938. Springer. [Book review.] 178

Pongrácz Sándor: Marais Eugene N.: Die Siel van die Mier. (A fehér hangya élete.) 1939. 2501 sok képpel. [Book review.] 178-180

Pongrácz Sándor: Vogt C. u. Vogt Oscar: Sitz und Wesen der Krankheiten und das Variiren der Tiere. Erscheinungsseiten der Variation. 1938. 324 1. 648 képpel. Leipzig, Ambrosius Barth. [Book review.] 180-181

Pongrácz Sándor: Stubbe H.: Spontane und Strahleninduzierte Mutabilität. 1937. 1901 1. 12 képpel. Leipzig, Georg Thieme. [Book review.] 181-182

Pongrácz Sándor: Kuhn O.: Die fossilen Reptilien. Berlin, 121 1. 92 képpel. 1937. Borntraeger. [Book review.]

Soós Lajos: Magyarországi folyóiratszemle. [Review of Hungarian periodicals.] .. 183-185

Krepuska Gyula: A magyar állattani irodalom 1938-ban. [The Hungarian zoological lirterature in 1938.] 186-199

Mödlinger Gusztáv: Szakosztályunk ülései. [Sessions of our section.] 199-202

\section{7. kötet - 1940}

\section{1-2. füzet:}

Gelei József: A soksejtü állati lény (Metazoon) fölénye az egysejtű (Protozoon) fölött. (Die Überlegenheit der Vielzeller über den Einzeller.)

Reök István: A reflex s ösztönös tevékenység és az öntudatos cselekedet szerepe az egyéni létezésben. (Reflex, instinktmässiges und bewusstes Handeln im individuellen Leben.)

Kormos József: Az ázalékállatok konjugációjának néhány problémája. (Über einige Probleme der Konjugation bei Infusorien.) $39-58$

Rotarides Mihály: A magyar állattan 35 éve az "Állattani Közlemények" tükrében. (35 Jahre ungarischer Zoologie im Spiegel der „Állattani Közlemények".) $58-70$

Soós Árpád: A magyarországi tőzegmoha-lápok fonalférgeiről. II.. (Die Nematoden der ungarischen Sphagnummoore. II.) 71-91

Pongrácz Sándor: Caullery M.: Les progres récents de l'embryologie expérimentale. Paris, Ed. Flammarion, 1939. 236 1. 395 képpel. [Book review.] 91-92 
Pongrácz Sándor: Kuhn Oskar: Die Stammesgeschichte der wirbellosen Tiere im Lichte der Paläontologie. Jena, Fischer, 1939. 94 képpel, 130 1.. [Book review.] 92-94

Wagner János: Pongrácz Sándor: Az ősködtől az emberig. (A Buvár könyvei, X.) 1-307 1. 45 képpel és 21 képmelléklettel. Budapest, 1940. Franklin-Társulat. [Book review.] 94-96

Székessy Vilmos: Tasnádi-Kubacska András: A mondák állatvilága. Kiadta a Királyi Magyar Természettudományi Társulat. Budapest, 1939. VIII. 372 oldal, 29 tábla és 49 szövegkép. [Book review.] 96-97

Tóth László: Buchner Paul: Allgemeine Zoologie. Quelle \& Meier, Leipzig, 1939. VIII+372 lap, 195 rajz. [Book review.]

Wagner János: Magyarországi folyóiratszemle. [Review of Hungarian periodicals.] .98-101

Mödlinger Gusztáv: Szakosztályunk ülései. [Sessions of our section.] 102-108

3-4. füzet:

Gelei József: Állati tökéletesség a véglény fokán. (Der organismische Vervollkommnungsgrad bei den Protozoen.) ................................................... 109-130

Sebestyén Olga: Magyarország édesvízi szivacsai és a hazai szivacsirodalom. (Fresh water sponges in Hungary and the Hungarian spongiological literature.) 130-140

Soós Lajos: Adatok az Északkeleti Kárpátok Mollusca-faunájának ismeretéhez. (A contribution to the Mollusc fauna of the North Eastern Carpathians.) $140-154$

Ábrahám Ambrus: Az emberi hasiagy (ganglion coeliacum) szerkezete. (Die Struktur des Ganglion coeliacum beim Menschen.) 154-163

Dózsa István: A sertés orrának záróberendezése. (Der Verschlussapparat des Nasenloches beim Schwein.) 164-169

Makara György \& Székely Sándor: Az Anopheles maculipennis maculipennis és messeae áttelelési módjára vonatkozó vizsgálatok. (Winterbeobachtungen über die Art der Durchwinterung von Anopheles maculipennis messeae und typicus.) 169-185

Soós Lajos: A magyar malakologia történetéhez. [To the history of the Hungarian malacology.] 186-188

Rotarides Mihály: Gaál István: A föld és az élet története. Budapest, 1939. A K. M. Természettudományi Társulat százéves fennállásának emlékére kiadott gyüjteményes munka: "A természet világa" IV. kötete. IV+392 oldal, 5 színes, 18 fekete mümelléklettel és 208 szövegközti képpel. [Book review.] 189-191

Pongrácz Sándor: Veszprémy Ferenc: Ösztön és faj. Budapest, 1938. Kir. Magy. Egyetemi Nyomda. 228 lap. [Book review.] 191-193

Pongrácz Sándor: Lichtig Ignaz: Die Entstehung des Lebens durch stetige Schöpfung. 1938. 361 o.. [Book review.] 193-194

Pongrácz Sándor: Clara Max: Entwicklungsgeschichte des Menschen. Leipzig, 1938. 4801. 204 képpel. [Book review.] 194-195 
Pongrácz Sándor: Mitchell Chalmers: The childhood of animals. Pelikan Books. London, 1940. 243 1.. [Book review.] 195-196

Wagner János: Örösi Pál Zoltán: Méhellenségek és a köpű állatvilága. Az Országos Magyar Méhészeti Egyesület kiadása. Budapest, 1939. 1-163 oldal, 19 szövegközti rajzzal és XVI fényképtáblával. [Book review.] 197

Krepuska Gyula: A magyar állattani irodalom 1939-ben. [The Hungarian zoological lirterature in 1939.] 197-211

Mödlinger Gusztáv: Szakosztályunk ülései. [Sessions of our section.] $212-214$

\section{8. kötet - 1941}

\section{1-2. füzet:}

Zimmermann Ágoston: Újabb adatok a mellékveséről. (Über die Nebenniere.) $1-9$

Wolsky Sándor: Adatok a regeneráció élettanához. (Contributions to the physiology of regeneration.)

Jaczó Imre: Néhány dunántúli átmeneti tőzegmoha-láp és Sphagnum előfordulás házas Rhizopodáiról. (Über die Rhizopoda testacea-Fauna einiger Übergangsmoore und Sphagnum-Vorkommen in Westungarn.) $18-34$

Soós Árpád: A magyarországi tőzegmoha-lápok fonalférgeiről. III. Az Északkeleti Kárpátok lápjai. (Die Nematoden der ungarischen Sphagnummoore. III.) .................... 35-48

Szilády Zoltán: A magyarországi gömblegyek (Cyrtidae). (Die Cyrtiden Ungarns.) .. 48-52

Anghi Csaba Geyza: Zsiráfok és maradványaik Magyarországon. (Giraffen und Giraffenreste in Ungarn.) 53-77

Szunyoghy János: Két új földikutya Kisázsiából. (Zwei neue Blindmäuse aus Kleinasien.) 78-86

Szilády Zoltán: Faunakutatásunk egységesítése. (Vereinheitlichung der Faunenforschung in Ungarn.) 87-92

Rotarides Mihály: Erdély csigafaunájának állatföldrajzi érdekessége. (Tiergeographische Charakterzüge der Schneckenfauna Siebenbürgens.) 92-112

Szilády Zoltán: Az Eristalis kormányzó mozdulatai. [The manoevering movements of Eristalis.]

Soós Lajos: Entz Géza és Sebestyén Olga: A Balaton élete. A Magyar Biologiai Kutatóintézet Munkái. XII. kötet. 1940. 1-168 old.. [Book review.] 113-116

Gaál István: Jeges Sándor: Természetrajz gyakorlati tanítások. II. rész. (Vezérkönyv Dr. Greguss Pál tankönyveihez). Szeged, 1939. 240 1., 172 kép. [Book review.] ... 116-118

Pongrácz Sándor: Rohracher H.: Die Vorgänge im Gehirn und das geistige Leben. Leipzig, 1939. 186 lap, 11 képpel. [Book review.] 118-120

Rotarides Mihály: Dobzhansky Theodosius: Die genetischen Grundlagen der Artbildung. Jena, 1939. VIII + 252 oldal. [Book review.] 120-122 
Magyarországi folyóiratszemle. [Review of Hungarian periodicals.]

$122-126$

Szakosztályunk ülései. [Sessions of our section.]

$126-130$

3-4. füzet:

Dudich Endre: Az állattani honismeret rögös útjain. (Auf dem beschwerlichen Pfade der zoologischen Heimatskunde in Ungarn.) $131-142$

Zimmermann Ágoston: A Gasser-féle dúc összehasonlító anatomiájához. (Zur vergleichenden Anatomie des Ganglion semilunare Gasseri.) ......................... 142-148

Zimmermann Gusztáv: Schistosoma reflexum totale érdekes esete. (Ein interessanter Fall von Schistosoma reflexum.) .................................................................... 148-158

Rotarides Mihály: Biotopképek jelentősége. (Über die Bedeutung von BiotopAbbildungen.) ........................................................................................ 158-163

Székessy Vilmos: "Vitás kérdések a légy-életből". Válasz dr. Szilády Zoltán-nak. („Strittige Fragen aus dem Leben der Fliegen". (Erwiderung an Herrn Dir. Dr. Zoltán Szilády).) $163-169$

Soós Árpád: Magyarország Acalyptrás Muscidái. I.: 1. Dryomyzidae, 2. Neottiophilidae, 3. Ulididae. (Über die acalyptren Musciden Ungarns.) $170-176$

Szilády Zoltán: Német fauna és magyar fauna. (Deutsche Fauna und ungarische Fauna.) 176-179

Ábrahám Ambrus: Receptorok az emberi sinus caroticus falában. (Receptoren in der Wand des Sinus caroticus des Menschen.) 179-183

Szunyoghy János: A vándor patkány anatomiája. I. A törzs váza. (Die Anatomie der Wanderratte (Mus norvegicus Erxl.). I. Rumpfskelett.) 184-197

Wagner János: A Gutin-hegység Mollusca-faunájának alapvetése. (Die Grundlage der Weichtierfauna des Gutin-Gebirges.) $197-210$

Wolsky Sándor: Újabb adat a Crustacea-szem heteromorph regenerációjának ismeretéhez. (A further contribution to the knowledge of heteromorphic regeneration of the Crustacean eye.) 211-219

Szilády Zoltán: Pótlások "A magyarországi gömblegyek" c. cikkhez. [Additions to the article "A magyarországi gömblegyek".]

Gaál István: Csiki Ernő állattani kutatásai Albániában. A Magyar Tudományos Akadémia Balkán-kutatásainak tudományos eredményei. I. kötet, 18 szövegközti rajzzal. (A M. T. Akadémia kiadása. 1922-1940). [Book review.] 220

Varga Lajos: Koenig Otto: Wunderland der wilden Vögel. Wien, 1939. 100 1., 92 fénykép, 1 térképvázlat. [Book review.] $221-222$

Varga Lajos: Wesenberg-Lund C.: Biologie der Süsswassertiere. Wirbellose Tiere Deutsche Ausgabe von O. Storch. XI + 817 old., 1138 szövegközti és 24 táblán levő rajzzal. Wien, 1939. [Book review.] 
Varga Lajos: Dotterweich H.: Das biologische Gleichgewicht und seine Bedeutung für die Hauptprobleme der Biologie. Jena, 1940. VII + 236 old., 34 ábra. [Book review.] 224-225

Sebestyén Olga: Lukács Károly: A Balaton. A Magyar Szemle Társaság Kincsestára. 114. sz. 2. kiadás. [Book review.] 225

Wagner János: Gregory K. W. és Raven C. H.: Gorillák nyomában. Fordította Szent-Ivány József, a fordítást átnézte és a függeléket írta Éhik Gyula. I-VI + 1-317 oldal, 32 táblával és 2 térképpel. Budapest, 1940. Királyi Magyar Természettudományi Társulat. [Book review.] $225-226$

Pongrácz Sándor: Ring Th.: Das Lebewesen im Rhytmus des Weltraums. 1939. Stuttgart. 290 1., 12 képpel. [Book review.]

Pongrácz Sándor: Krügger W.: Unser Pferd und seine Vorfahren. Berlin, 1939. 170 1., 77 képpel. [Book review.]

228-229

Rotarides Mihály: Brohmer Paul: Die Lebensgemeinschaften. Ein Lehrer-Handbuch für den Biologieunterricht. Zweite Auflage. Osterwieck/Harz und Berlin, 1938-1939. [Book review.] $229-230$

Soós Lajos: Zimmermann Ágoston és Zimmermann Gusztáv: Háziállatok anatomiája és élettana. Budapest, 1941. 113 1. 20 képpel. [Book review.] 231

Krepuska Gyula: A magyar állattani irodalom 1940-ben. [The Hungarian zoological lirterature in 1940.] 231-242

Szakosztályunk ülései. [Sessions of our section.] 242-246

\section{9. kötet - 1942}

\section{1-2. füzet:}

Az Állattani Szakosztály 50 éves fennállását ünneplő 417. ülés 1941 december hó 4-én. [Anniversary session celebrating the 50 years of the Zoological Section.] $1-6$

Rotarides Mihály: Az Állattani Szakosztály megalakulásának története. (Die Geschichte der Gründung der Zoologischen Sektion der Kgl. Ung. Naturwissenschaftlichen Gesellschaft.) 6-9, 109-110

Soós Lajos: Szakosztályunk szerepe és hatása a magyar zoológiai életben. (Die Rolle und der Einfluss der Zoologischen Sektion auf das Leben der Zoologie in Ungarn.) 10-15, 110-111

Dudich Endre: Az elnöki beszédek gondolatvilága. (Der Gedankenwelt der Eröffnungsansprachen der Vorsitzenden.) 15-26, 111-112

Az elnöki beszédek jegyzéke. [List of the speaches of the section's presidents.] 26-27

Az Állattani Szakosztály tisztikara, 1891-1941. [The board of the Zoological Section, 1891-1941.]

Dudich Endre: A tisztikar tagjainak életrajzi adatai. [Biographies of the board members.] 28-40 
A szakosztályi folyóiratok bibliográfiai adatai. [Bibligraphic data of the journals of the Section.] 40-42

Beszámolók az Állattani Szakosztály müködéséről. 1891-1941. [Reports on the activity of the Zoological Section, 1891-1941.]

Rotarides Mihály: Az Állattani Szakosztály ötven éves működése. (Das 50-jährige Wirken der Zoologischen Sektion.) ...................................................................... 43-103

Dudich Endre: Animalia nova in fasciculis "Pótfüzetek" (Állattani Közlemények dictis) 1900-1901. descripta. ........................................................................... 103-105

Dudich Endre: Animalia nova in tomis I-XXXVIII. "Állattani Közlemények" descripta. 105-108

\section{3-4. füzet:}

Dudich Endre: Id. Entz Géza emlékezete születésének százéves évfordulója alkalmából. (Zur Erinnerung Professor Dr. Géza Entz sen.) 113-124

Szunyoghy János: A pusztai görény (Putorius Eversmanni Less.) Magyarországon. (Über das Vorkommen des Steppeniltisses (Putorius Eversmanni Less.) in Ungarn.) . 124-130

Lumnitzer Györgyi: Histophysiologiai napi ritmus vizsgálatok a békák máján. (Histophysiologische Untersuchungen über den Tagesrhytmus der Froschleber.) 130-146

Homonnay Nándor: A madarak ökológiai plaszticitása. (Die ökologische Plastizität der Vögel.) $146-165$

Edelényi Béla: A Szeged környéki békák belső élősködő férgei. (Die endoparasitischen Würmer der Frösche von der Umgebung der Stadt Szeged.) 165-183

Keve-Kleiner Endre: A rasszkör-elv gondolatának kialakulása. (Dr. Kleinschmidt Ottó 70. születésnapja alkalmából). (Die Entwicklung der Rassenkreisprinzip-Idee.) ..... 183-188

Wolsky Sándor: A megtermékenyítés és ivarmeghatározás anyagi alapjai. (The material basis of fertilization and sexuality.) ............................................................. 188-203

Sebestyén Olga: A turzások jelentősége a Balaton életének megismerésében. (The value of drift in studying the life of Lake Balaton.) ....................................................... 204-208

Zilahi-Sebess Géza: A Lithocolletis platani Stgr. fejlődéséről. (Über der Entwicklung der Lithocolletis platani Stgr.) 208-215

Zimmermann Ágoston: A hullamerevségről. (Über die Totenstarre.) ..................... 215-222

Unger Emil: Az ökológia és a közgazdaságtan analogiáiról és valóságos összefüggéseiről. (Über Analogien und wirkliche Zusammenhänge zwischen Ökologie und Volkswirtschaftslehre.) 222-248

Balogh Ernő: Új adat a nyest életmódjának ismeretéhez. [New data to the life of the Beech Marten.] 248-251

Szilády Zoltán: Vitás kérdések. [Disputable topics.] 251-252

Dudich Endre: A magyar tenger könyve. Entz Géza és Sebestyén Olga: A Balaton élete c. könyvének ismertetése. [Book review.] 253-256 
Wolsky Sándor: Beznák Aladár: Orvosi élettan. Budapest, Magyar Orvosi Könyvkiadó Társulat kiadása. I. kötet 1938, II. kötet 1941. [Book review.] 256-257

Soós Lajos: Zimmermann Ágoston és Zimmermann Gusztáv: Háziállatok anatómiájának kézi atlasza. 896 képpel. II. kiadás. Budapest, 1942. [Book review.] $257-258$

Dudich Endre: Zalányi Béla: Bioszociologiai összefüggések a nagyalföldi neogén medencében. A Földtani Intézet Évi Jel., 1933-35, IV. kötet, 1941. p. 1621-1699, 6 tábla és 7 ábra. [Book review.] $258-259$

Keve-Kleiner Endre: Ornithologica Balcanica. [könyvismertetések]. [Book review.] 260-261

Sassi Móric: Seitz Alfred: Die Brutvögel des "Seewinkels". Heft 12. Reihe "Niederdonau, Natur und Kultur". Verlag K. Kühne, Wien-Leipzig, 1942, pp. 52, 12 tábla. [Book review.]

Krepuska Gyula: A magyar állattani irodalom 1941-ben. [The Hungarian zoological literature in 1941.] 261-274

Szakosztályunk ülései. [Sessions of our section.] 274-282

\section{0. kötet - 1943}

\section{1-2. füzet:}

Kesselyák Adorján: Telepes hydroidpolyp a Tiszából. (Stockbildende Hydroidpolyp aus der Tisza.) $1-14$

Ábrahám Ambrus: Az ember nyelvének érző idegvégszervei. (Über die sensiblen Nervenendorgane in der Zunge des Menschen.) $15-22$

Szunyoghy János: A vándor patkány anatomiája. II.: Szabad végtagok váza. (Die Anatomie der Wanderratte (Mus norvegicus Erxl.). II. Das Skelett der freien Gliedmassen.) 22-35

Wagner János: Az 1942. évi erdélyi kutatóutak malakológiai eredményei. (Malakologische Ergebnisse der siebenbürgischen Forschungsreisen im Jahre 1942.) 35-49

Homonnay Nándor: A madárvilág néhány szociologiai kapcsolatáról. Megjegyzések "A Hortobágy madárvilága" (Tisia, 1941) c. dolgozathoz. (Über einige soziologische Zusammenhänge in der Vogelwelt. Anmerkungen zu der Arbeit „Die Vogelwelt der Hortobágy" (Tisia 1941).) 49-63

Rotarides Mihály: Új barlangi csiga Erdélyből. (Eine neue Höhlenschnecke aus Ungarn.) 64-68

Soós Árpád: Magyarország acalyptrás Muscidái. II. (Über die acalyptraten Musciden Ungarns.) 68-77

Fábián Gyula: Mutációk egy vad Drosophila törzsben. (Mutations in a wild-stock of Drosophila.) $77-103$

Keve-Kleiner András: Biotop, revir, élettér, életkör. [Biotope, home range, territory, lifecircle.] 103-105 
Wolsky Sándor: Az állat és élete. I. rész. Írta: Kesselyák Adorján, Pongrácz Sándor, Rotarides Mihály és Soós Lajos. A természet világa, IX. kötet. Szerkesztette: Soós Lajos. 396 oldal, 4 színes, 20 fekete mümelléklettel és 225 szövegközti képpel. Budapest, 1942, Kir.Magy. Természettud. Társulat kiadása. [Book review.] 105-106

Varga Lajos: Az állat és élete. II. rész. Írta: Dudich Endre és Hankó Béla. A természet világa, X. kötet. Szerkesztette: Dudich Endre. VI+456 old., 4 színes, 20 fekete mümelléklettel és 311 szövegközti képpel. Budapest, 1942, Kir. Magy. Természettud. Társulat. [Book review.] 107-109

Dudich Endre: Pénzes Antal: Budapest élővilága. K. M. Természettudományi Társulat könyvkiadóvállalata. 125. k., 1942. XVIII + 236 lap, 80 tábla, 32 kép és 1 térkép. [Book review.] 110-111

Unger Emil: Mika Ferenc és vitéz Varga Lajos: Természetes pisztrángos vizeink hasznosítása. 107 oldal, mülapokon 14 képpel. Az Országos Halászati Egyesület kiadása. Budapest, 1942. [Book review.] 111

Wagner János: Gorka Sándor: A mai biologia világképe. "A mai világ képe" IV. kötet, 171 oldal, Budapest, 1942. Kir. Magy. Egyetemi Nyomda. [Book review.] ........ 111-112

Keve-Kleiner András: Chopard L., Bertin, L., Berlioz J., Laurent P.: Les migrations animales. L. Cuénot előszavával. (L'Avenir de la Science, no. 17, Lagnysur-Marne, 1942, pp. 245. [Book review.]

Soós Árpád: Szakosztályunk ülései. [Sessions of our section.] $113-120$

3-4. füzet:

Maucha Rezső: A vizek életegyensúlyának törvényszerüségeiről. (Die Gesetzmässigkeiten des biologischen Gleichgewichtes in den Gewässern.) 8-139

Kesselyák Adorján: A közönséges viziászka ivadékgondozásának lényege, az ászkarákok törzsfejlődésének megvilágításával. (Physiologie der Brutpflege des Asellus aquaticus (L.) und die phylogenetische Konsekvenzen derselben.) $139-158$

Mödlinger Gusztáv: A tengeri malac pajzsmirigye finomabb szerkezetének évszakos változásai. (Die Jahreszyklischen Veränderungen in der feineren Struktur der Schilddrüse der Meerschweinchen.) 159-172

Sebestyén Olga: Limnológiai problémák hazai vonatkozásban. (A "sekély tavak" kérdéséhez). (The question of ,shallowlakes”.) 172-176

Sebestyén Olga: Néhány szó balatoni állatok méreteiröl. (A remark on the size of some inhabitants of Lake Balaton.) 176-177

Apor László \& Stohl Gábor: A galamb hyphophysisének napszakos változásai. (Die tagesrhythmischen Veränderungen in der Hypophyse der Taube.) 177-187

Tóth László: Az endosymbiosis egy új kategóriája. A növénynedvszívó rovarok endosymbiosisának élettani értelmezése. (On a new category of endosymbiosis. Physiological interpretation of the endosymbiosis of plant-juice sucking Insects.) 188-193

Jaczó Imre: Adatok a kecskerák (Astacus leptodactylus Eschh.) postembrionális fejlődéséhez. (Daten zur Entwicklung von Astacus leptodactylus.) 194-197 
Jaczó Imre: Biometriai vizsgálatok édesvizi rákokon. (Biometrische Untersuchungen an Süsswasserkrebsen.) 197-207

Zimmermann Ágoston: A nyirokcsomók öregkori elváltozásairól. (Über die Altersveränderungen der Lymphknoten.) 207-215

Zimmermann Gusztáv: A sertés orrának melléköbleiről. (Die Nebenhöhlen der Nase des Schweines.) 216-221

Chappuis, P. A.: Über die Fauna der Spaltengewässer und des Grundwassers = A talaj- és hasadékvizek állatvilágáról. (Über die Fauna der Spaltengewässer und des Grundwassers) 221-232

Boros Ádám: Flórakutatási tapasztalatok faunakutatóknak Magyarországon. (Über Erfahrungen der Floristen im Dienste der faunistischen Forschungen in Ungarn.) 233-238

Wolsky Sándor \& Jaczó Imre: Adatok a kecskerák (Astacus leptodactylus Eschh.) anyagcseréjének ismeretéhez. (Further contributions to the knowledge of metabolism in Astacus leptodactylus Eschh.) $238-242$

Ábrahám Ambrus: Idegvégtestek az arteria renalis falában. (Nervenendkörperchen in der Wandung der Arteria renalis.) $242-252$

Udvardy Miklós: Palmgren Pontus kvantitativ madártani módszeréről. (Pontus Palmgren 's quantitative Methode in der Ornithologie.) 252-259

Soós Lajos: Az élet tudománya. Szerkesztette Szent-Györgyi Albert. A müvelődés könyvtára, 3-ik kötet. 148 szövegábrával és 16 képtáblán 50 képpel. Új Idők irodalmi intézet rt. kiadása. Budapest (1943). [Book review.] 260-263

Wolsky Sándor: Pongrácz Sándor: A mindennapi élet biologiája. 240 oldal, 69 képpel és 1 térképpel. Budapest, Franklin-Társulat kiadása. A Búvár könyvei, XVIII.. [Book review.] 263-265

Pongrácz Sándor: Eugster J. und Hess V. F.: Die Weltraumstrahlung und ihre biologische Wirkung. Zürich, 1941. 198 1., 54 képpel. [Book review.] 265-266

Pongrácz Sándor: Wohlbold Hans: Wunder der Tiergemeinschaften. Berlin, 1941. 287 1., 48 képpel. [Book review.] $266-268$

Pongrácz Sándor: Abderhalden E.: Lehrbuch der physiologischen Chemie. 8., völlig bearbeitete Auflage. 1942, 297 1., 39 képpel. [Book review.] .......................... 268-269

Krepuska Gyula: A magyar állattani irodalom 1942-ben. [The Hungarian zoological lirterature in 1942.] 270-281

Soós Árpád: Szakosztályunk ülései. [Sessions of our section.] $282-284$

\section{1. kötet - 1944 (1945)}

Stohl Gábor: Az emlősök mellékvesekérgének hisztofiziológiai vizsgálata. (Histophysiologische Untersuchungen an der Nebennierenrinde verschiedener Säugetiere.) $1-16$ 
Dudich Endre: Linné és az állatnevek logikája. (Linné und die Logik der Tiernahmen.) 16-31

Steif Antal: Néhány rovar irányítatlan mozgásáról. (Über die ungerichteten Bewegungen einiger Insekten.) $31-36$

Stohl Gábor: A tengeri állatok lélekzésének napszakos ritmusa. [The daily rythm of the

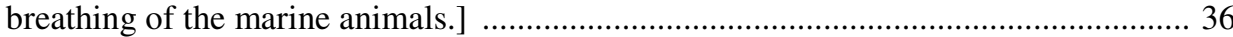

Soós Árpád: Szakosztályunk ülései. (Comptes rendus des séances de notre section.) . 37-40

\section{2. kötet - 1945}

Éhik Gyula: Elnöki megnyitó. (Eröffnungsansprache des Vorsitzenden.) $1-4$

Zimmermann Ágoston: A házinyúl arterio-vénás anastomosisairól. (Über die arteriovenösen Anastomosen beim Kaninchen.) 4-14

Ábrahám Ambrus: Pressoreceptorok az aortaívben. (Pressoreceptoren im Aortenbogen.) 14-19

Zimmermann Gusztáv: Intersexualitás és hermaphroditismus. (Intersexualität und Hermaphroditismus.) $20-26$

Stohl Gábor: A kéz formájának kialakulása. [The development of the shape of the hand.] $26-27$

Soós Árpád: Szakosztályunk ülései. (Comptes rendus des séances de notre section.) . 27-32

\section{3. kötet - 1946}

Balogh János: Az életközösségek szerkezete. (The structure of the biocenoses.) $1-14$

Mózes Imre: A hátulsó üres véna májbillentyűjéről. (Über die Leberklappe der hinteren Hohlvene.) $14-17$

Jászfalusi Lajos: Az ésszerü halászat irányelvei a Kárpátmedence pisztrángos folyóvízeiben. (Les principes de la peche rationnelle dans les cours d'eaux à truites du Bassin des Carpathes.) $18-34$

Stohl Gábor: A kvagga-tigrislovak származástani kapcsolatairól. (Of the phylogenetical connections of the tiger-horses of the group quagga.) $35-40$

Zimmermann Gusztáv: A Douglas-féle redő összehasonlító anatómiájához. (Zur vergleichenden Anatomie der Douglas'schen Falte.) $41-44$

Rotarides Mihály: A vízbejáró házatlan csiga kérdéséhez. [To the topic of the water-visiting slug.] 45-46

Stohl Gábor: Kezdetleges állatok voltak-e a Palaeodictyopterák? [Were palaeodictyopterids primitive animals?] 46-47

Stohl Gábor: Szakosztályunk ülései. (Comptes rendus des séances de notre section.) 47-52 


\section{4. kötet - 1954}

\section{1-2. füzet:}

Mödlinger Gusztáv: Beköszöntő. [Introduction.] 3-4

Varga Lajos: Gelei József emlékezete. (Zur Erinnerung an József Gelei.) .................... 5-21

Boros István: A magyar zoológia soronlévő feladatai. (The tasks of Hungarian zoology awaiting immediate solution.) ....................................................................... 23-35

Zimmermann Gusztáv: Összehasonlító tájbonctani vizsgálatok a Parathyreoideáról. (Zur topographischen Anatomie der Parathyreoidea.) ................................................ 37-41

Topál György: Denevérgyürüzés Magyarországon. I. rész. (Beringen von Fledermäusen in Ungarn.) $43-48$

Horváth Lajos: Madártani vizsgálatok a Tüskés-pusztai halastavakon. (Ornithological investigations in the fishponds of Tüskés-puszta.) 49-59

Szunyoghy János: Az Ablepharus kitaibeli kitaibeli Bibron \& Bory új lelőhelye Magyarországon. (A new occurence of the Ablepharus kitaibeli kitaibeli Bibron \& Bory in Hungary.) $61-62$

Horváth Andor: Az alföldi lápok puhatestüiröl és az Alföld változásairól. (Sur les mollusques des marais de l'Alföld et sur les changements de la Plaine Hongroise.) $63-70$

Kaszab Zoltán: A Csendes-óceáni szigetek Tenebrionidáinak (Coleoptera) biogeográfiája. (Zur Biogeographie der Tenebrioniden der Pazifischen Inseln.) $71-79$

Mihályi Ferenc: Előzetes vizsgálatok a dunai szúnyogkérdés megoldásához. (Preliminary investigations on a solution of the mosquito problem along the Danube.) $81-86$

Lukács Dezső: Adatok a planáriák és a Sadleriana pannonica Bükk-hegységi elterjedésének ismeretéhez. (Beiträge zur Kenntnis der Verbreitung der Planarien und der Schneckenart Sadleriana pannonica im Bükk-Gebirge.) 87-93

Kovács István Endre: Első vizsgálatok az aggteleki Békebarlang faunáján. (Erste Untersuchungen über die Fauna der Höhle Békebarlang in Aggtelek.) ................. 95-98

Szunyoghy János: Milyen állatot neveztek eredetileg a "pegymet" szóval? (What animal was originally meant by the word ,,pegymet”?) 99-102

Kaszab Zoltán: Dudich Endre: Az állatok gyüjtése. I. rész. 195 oldal, 57 szövegközti ábra, Budapest, 1948, Népszerü Könyvek III. kötet, az országos Természettudományi Múzeum kiadása. [Book review.]

Kotlán Sándor: Dudich Endre: A rovargyüjtés technikája. 250 oldal, 100 képpel, Bp., 1951. Közoktatásügyi Kiadóvállalat. [Book review.] 103-104

Soós Lajos: Állathatározó. Szerzette a [...] munkaközösség Móczár László vezetésével. A Szocialista Nevelés Könyvtára, 8. szám. Bp., 1950. I. kötet, szöveg, 794 oldal, II. kötet 247 tábla és névmutató (240-342 oldal). [Book review.] 104-105

Soós Lajos: A Magyar Nemzeti Múzeum - Természettudományi Múzeum Évkönyve. Annales Historico-Naturales Musei Nationalis Hungarici. Új sorozat, III. kötet, 1952, IV. kötet, 1953. [Book review.] 105-107 
Loksa Imre: Szakosztályunk ülései. [Sessions of our section.]

$109-111$

3-4. füzet:

Ábrahám Ambrus \& Stammer Aranka: A madarak szemmozgató izmainak beidegzése, tekintettel a ganglion ciliare szerkezetére. (Die Innervation der Augenmuskeln der Vögel.) 115-134, +10 tábla

Beretzk Péter: A lócsér Magyarországon. (Die Raubseeschwalbe (Hydroprogne caspia Pall.) in Ungarn.) 135-147

Erdős József: Az Eridontomerus Crawf. nemzetség (Torymidae, Hymen.) fajai. (Species generis Eridontomerus Crawf. (Torymidae, Hymen.) 149-160

Fábián Gyula: Reciprok-hybridek eltéréseiről, egér- és nyúlkísérletek alapján. (Data of mouse and rabbit experiments on differences in reciprocal hybrids.) $161-169$

Horváth Andor: A paksi pleisztocén-üledékek csigái és értékelésük. (The snails of the Pleistocene deposits at Paks.) $171-188$

Krolopp Endre: Néhány malakofaunisztikai adat a Dunántúlról. (Einige malakofaunistische Angaben aus Westungarn.) 189-191

Stiller Jolán: A Vorticella microstoma Ehrenberg (Peritricha, Ciliata) mint az ökológiailag különböző vízek bioindikátora. (Vorticella microstoma Ehrenberg (Peritricha, Ciliata) als Bioindikator ökologisch verschiedener Gewässer.) 193-200

Stiller Jolán: Környezeti hatások által kiváltott módosulatok epizoikus Peritrichákon. (Durch Umweltseinflüsse entstandene Modifikationen epizoischer Peritrichen.) 201-211

Stohl Gábor: A háziállatok eredetének néhány vitás kérdése (Einige Probleme der Abstammungslehre unserer Haustiere.) 213-217

Szelényi Gusztáv: Kártétel-előrejelzés a növényvédelemben. (Schädlingsprognose und Pflanzenschutz.) 219-224

Szunyoghy János: Adatok a Microtus oeconomus méhelyi Éhik elterjedésének, halló- és peniscsontjának ismeretéhez. (Beiträge zur Kenntnis der Verbreitung, sowie der Gehörknöchelchen und des Penisknochens von Microtus oeconomus méhelyi Éhik.) 225-230

Topál György: Denevérgyürüzés Magyarországon. II. rész. (Beringen von Fledermäusen in Ungarn. II. Teil.) 231-238, +2 táblázat

Tusnádi Győző, ifj.: Biológiai védekezés ragadozó madarakkal halastavaink szárnyas kártevői ellen. (Défense biologique par des rapaces contre les alifères nuisibles de nos étangs à poissons.) $239-242$

Varga Lajos: A "tó" fogalmáról, figyelemmel hazai állóvízeinkre. (Zur Frage des SeeBegriffes, mit besonderer Berücksichtigung der ungarischen stehenden Gewässer.) $243-255$

Vágvölgyi József: A Kárpátok malakofaunájának kialakulása. (Development of the malacofauna of the Carpathians.) $257-278$

Woynárovich Elek: A vízek táplálék- és energiakörforgalmának mennyiségi általánosított ábrázolása. (Generalized diagrammatic illustration of food and energy cycles in waters.) 
Zimmermann Ágoston: A házimacska szájkörüli szerveiről. (Über die circumoralen Organe der Hauskatze.)

287-293

Boros István: Székessy Vilmos: Bátorliget élővilága. Akadémiai Könyvkiadó, Bp., 1953. [Book review.]

Kovács Lajos: Balogh János: A zoocönológia alapjai - Grundzüge der Zoozönologie. Akadémiai Kiadó, Bp., 1953. [Book review.]

Török László: Szakosztályunk ülései. [Sessions of our section.] 299-303

\section{5. kötet - 1955-1956}

\section{1-2. füzet:}

Soós Lajos: Megemlékezés Wagner Jánosról és Rotarides Mihályról. [In memoriam János Wagner and Mihály Rotarides.]

Székessy Vilmos: Csiki Ernő emlékezete. (Dem Gedächtnis E. Csiki's.) $7-10$

Bartha Ferenc \& Cs. Halászfy Éva: A Pyrrhocoris apterus L. csáphosszának változékonysága és a csápok rendellenes fejlődése. (La variabilité de la longueur d'antenne du Pyrrhocoris apterus L. et le développement anormal des antennes.) $11-20$

Biczók Ferenc: A Pápakovácsi-rét rizoszféra-protozoáinak vizsgálata. (Investigations of the Protozoa from the rhizosphere of the field of Pápakovácsi.) 21-32, +5 táblázat

Erdős József: Megfigyelések a nád kártevőiről és azok parazitáiról. (Observationes de insectis nocivis eorumque parasitis in Phragmite vulgari Lam.) $33-48$

Horváth Lajos: A sárgafejü királyka magyarországi fészkelésének első bizonyítéka. (First evidence for nidification in Hungary of the Goldcrest.) 49-53

Jászfalusi Lajos: Tenyészpontyok csontvázrendellenességei. (Les anomalies de squelette des earpes séléctionnées.)

Kulcsárné Gergely Judit: Adatok a lép histophysiológiájához. (Beiträge zur Histophysiologie der Milz.) $61-66$

Méhes Gyula: Ethológiai tanulmányok tölgyfagubacsokon és gubacsdarazsakon. (Etudes étiologiques sur les galles du chéne et sur les cynips.) $67-73$

Ponyi Jenő: Ökológiai és táplálkozásbiológiai vizsgálatok a Gammarusok köréből. (Ökologische und ernährungsbiologische Untersuchungen an verschiedenen Gammarus-Arten.) 75-90

Soós Árpád: Magyarország kullancslegyei (Hippoboscidae). (Die Lausfliegcn (Ilippoboscidae) Ungarns.) 91-96

Soós Lajos: A magyarországi Daudebardiák kérdéséhez. (On Hungarian Daudebardiae) .97-105

Székessy Vilmos: Legyezőszárnyúak - Strepsiptera W. Kirby. (Fiicherfliiger - Strepsiptera W. Kirby.) 107-122 
Sztankayné Gulyás Magdolna, Fornosi Ferenc \& Molnár Erzsébet: Az encephalomyelitisvírus izolálása kullancsokból II. Az anyag gyüjtése és feldolgozása. (Isolation of the Virus of Encephalomyelitis from Ticks. Part II.) $123-129$

Szunyoghy János: Kisemlősgyüjtés. (Sammeln von Kleinsäugetieren.) $131-138$

Török László: A colchicin hatása a Planaria lugubris O. Schm. regenerációjára. (L'effet de la colchicine sur la régénération de la Planaria lugubris O. Sehnt.) 139-147

Zimmermann Ágoston: A sertés gyomrának méreteiről. (Über die Massverhältnisse des Schweineinagens.) 149-154

Ábrahám Ambrus: Megyeri-Török-Wéber: Általános állattan. Tankönyv a pedagógiai főiskolák számára. [Book review.] $155-156$

Székessy Vilmos: H. Franz: Die Nordost-Alpen im Spiegel ihrer Landtierwelt. Eine Gebietsmonographie umfassend: Fauna, Faunengeschichte, Lebensgemeinschaften und Beeinflussung der Tierwelt durch den Menschen. I. Bd. Universitätsverlag Wagner, Innsbruck, 1954, pp. 664. [Book review.] $156-157$

Török László \& Horváth Lajos: Szakosztályunk ülései. [Sessions of our section.] . 158-160

3-4. füzet:

Dudich Endre: Kesselyák Adorján emlékezete. (Adorján Kesselyák (Nécrologue).) ...... 3-8

Móczár László: Szabó-Patay József emlékezete. (József Szabó-Patays zum Gedenken.) 9-12

Ábrahám Ambrus, Horváth Andor \& Megyeri János: Hidrobiológiai vizsgálatok a Szilvás patak vízgyüjtő területén. (Hydrobiologische Untersuchungen im WasserspeicherGebiet des Baches Szilvás.) $13-24$

Bende Sándor: A ponty agyvelejének makroszkópos anatómiája. (Der makroskopische Aufbau des Gehirns beim Karpfen.) 25-34

Berczik Árpád: Újabb hidrobiológiai vizsgálatok a Lukács gyógyfürdő Malom-taván. (Neuere hydrobiologische Untersuchungen im thermalen Teich des Lukas-Bades in Budapest.) $35-44$

Berinkey László \& Farkas Henrik: Haltáplálékvizsgálatok a Soroksári-Dunaágban. (L'examen de la nourriture des poissons de la brauche Soroksár du Danube.) $45-58$

Bierbauer József: A Helix pomatia regenerációs és szövettani vizsgálata. (Regeneration and histological investigation of the Helix pomatia.) 59-68

Éhik Gyula: Néhány súlyadat emlőseink ismeretéhez. [Some data on the weight of our mammals.]

Gere Géza: Erdei avarfogyasztó Diplopoda és Isopoda fajok humifikációs szerepének vizsgálata növénynevelési módszerrel. (The role of diplopods and isopods in humification studied with the plant growing method.) $71-78$

Jermy Tibor: Növényvédelmi problémák megoldásának cönológiai alapjai. (Cenological basis of the solution of some problems in plant protection.) $79-88$

Keve András: A balkáni fakopáncs terjeszkedése. (The areal expansion of the Syrian Woodpecker.) 89-91 
Móczár Miklós: Magyarországi pelyhesméhek (Anthidium Fabr.). (Les anthidies (Anthidium Fabr.) de la Hongrie.) 93-100

Ónodi L. Ágnes: A Gammarus roeseli térfogatmérése. (Le calcul du volume du Gammarus roeseli.) $101-106$

Ponyi Jenő: A balatoni hínárosok Crustaceáinak vizsgálata. (Untersuchungen an Crustaceen in Tanggebilden des Balatons.) $107-121$

Szabó István: Adatok a Szentendre-Visegrád-Esztergomi Dunazúghegység herpetofaunájához. (Contributions à l'herpétofaune de la montagne Dunazug entre Szentendre, Visegrád et Esztergom.) $123-131$

Szelényi Gusztáv: Zoocönózis vagy koexisztencia? (Zoozönose oder Koexistenz?) 133-142

Szunyoghy János: Hazataláló képesség vizsgálata kisemlősöknél. (Homing experiments on small mammals.) $143-147$

Varga Lajos: Adatok a hazai Sphagnum-lápok vízi mikrofaunájának ismeretéhez. (Contributions to the aquatic microfauna of the Sphagnum marshes in Hungary.) $149-158$

Zimmermann Ágoston: A nemzetközi anatómiai nomenklaturáról. (Über die anatomische Nomenklatur.) 159-171

Székessy Vilmos: Magyarország állatvilága. (Kiadja a Magyar Tudományos Akadémia támogatásával az Akadémiai Kiadó). [Book review.] $173-176$

Szalay László: Karl Viets: Die Milben des Süsswassers und des Meeres. I.: Bibliographie. Gustav Fischer Verl., Jena, 1955. p I-IV + 1-476, 163 arcképpel). [Book review.] $176-177$

Kovács István: Rovartani Közlemények. Új sorozat, VIII. kötet, 1955. [Book review.] $177-178$

Horváth Lajos: Szakosztályunk ülései. [Sessions of our section.] $179-184$

\section{6. kötet - 1957}

\section{1-2. füzet:}

Boros István: Megemlékezés Pongrácz Sándorról. [In memoriam Sándor Pongrácz.] .... 3-8 Timár Lajos: Megemlékezés Czógler Kálmánról. [In memoriam Kálmán Czógler.] ... 9-10 Warga Kálmán: Petényi Salamon az ornitológus. [Salamon Petényi, the ornitologist.] 11-18 Ambrus Béla: Ökológiai megfigyelések a gubacsfaunában. A csepelszigeti Kisduna-ág és a Szilvásvárad-Szalajkavölgy gubacsai. (Ecological observations concerning the gallnutfauna. Ökologische Beobachtungen über die Gallapfel-Fauna Unga.rns.) 19-32

Berczik Árpád: Chironomidák, és a tótipustan néhány hazai kérdése. (Chironomiden und einige heimische Fragen der Seetypenlehre.) $33-41$

Csanády György \& Vágás Endre: A házimacska epehólyagjának rendellenességei. (Irrégularités de la vésicule biliaire du chat, Felis domestica) $43-47$ 
Erdős József: Újabb megfigyelések a nád rovarbiológiájáról. (Recentiores observationes entomocoenologicae in Phragmites communi Trin.) 49-65

Farkas Henrik: Adatok az Abaligeti-barlang állatvilágának ismeretéhez. (Beiträge zur Kenntnis der Tierwelt der Höhle von Abaliget.) 67-69

Gere Géza: Az élőlények produkcióbiológiai csoportosítása és szerepük az életközösségekben. (Le groupement des étres vivants selon la biologie de production et leur rôle dans les biocénoses.) $71-78$

Horváth Lajos: Avifaunisztikai megfigyelések a Fekete-tengeren és partvidékén Várnától Batumig. (Avifaunistic observations on the Black Sea and its coastal districts between Varna and Batumi.) 79-85

Horváth Lajos: Magyar madárnevek és írásmódjuk. (Denominations des oiseaux en Hongrois.) 87-90

Jermy Tibor: A biocönózisok egyensúlyának kérdéséhez. (Zur Frage des biozönotischen Gleichgewichtes.) 91-98

Pintér István: Adatok Keszthely környékének Mollusca-faunájához. (Beiträge zur Molluskenfauna der Umgebung von Keszthely.) 99-114

Stammer Aranka: Az édesvízi csontoshalak szemizmainak szerkezete és beidegzése. (Structure and innervation of the eye-muscles of fresh-water osseous fishes.) .. 115-123

Szelényi Gusztáv: Az állattársulási kategóriák. (Die zoozönologischen Kategorien.) $125-138$

Zimmermann Ágoston: A házimacska carpalis vibrissái. (Uber die Carpalvibrissen der Hauskatze.)

Zimmermann Ágoston: Összehasonlító izomtani vizsgálatok néhány kevéssé ismert vagy félreismert izomról. (Comparative myological examinations.) $147-152$

Szalay László: Karl Viets: Die Milben des Süsswassers und des Meeres. 2/3. Katalog und Nomenklator. Gustav Fischer Verl., Jena, 1956. p. 1-870, 140 szövegábrával. [Book review.] $153-154$

Szalay László: Beiträge zur neotropischen Fauna. [Book review.] 154

3-4. füzet:

Ambrus Béla: Állatföldrajzi vizsgálatok Sopron és környékének gubacsfaunáján. (Zoogeographical bearings of the gall-nuts in Sopron and its surroundings.) .... 159-175

Bierbauer József: A tejmirigy szövettani és fejlődéstani vizsgálata. [Cytological and developmental studies on the milk glands.] $177-185$

Buchert Ádám \& Wéber Mihály: A Microhydra germanica Roch a magyar faunában. (Microhydra germanica Roch in der ungarischen Fauna.) 187-194

Dorning Henrik: Néhány megjegyzés a madarak fürdéséről. (Some remarks on the bathing of birds.) 195-198

Gebhardt Antal: A dömörkapui mészsziklák (Mecsek-hegység) Mollusca-faunájának cönológiai vizsgálata. (Téli aspektus.) (L'examen cénologique de la fauné de mollusques des calcaires de Dömörkapu (Massif de Mecsek). Aspect hivernal.) 199-219 
Győrfi János: A nyárfélék kislepke károsítói. (Microlepidoptera damaging poplar trees.) $221-227$

Jermy Tibor \& Szelényi Gusztáv: Az őszibúza állattársulásai. (Die Zoozönose des Winterweizens.) $229-241$

Keve András: Adatok Moçambique madárvilágához. (Mitteilungen zur Ornis von Mozambique.)

Krolopp Endre: A Budai-hegység csigafaunájának kialakulása. (Die Evolution der Schneckenfauna des Budaer (Ofner) Gebirges.) $245-253$

Lukács Dezső: Az egri langyosvíz zooökológiai viszonyai. (Les conditions zooécologiques de l'eau tiéde de Eger.) $255-260$

Móczár László: A Crabro s. lat. nem reviziója (Hymenoptera: Sphecidae). (Die Revision des Genus s. 1. Crabro (Hymenoptera, Sphecidae).) 261-272

Nagy István Zoltán: Cephalopoda-rágószerv a mecseki középső jura (Bath) rétegeiből. (Ein Cephalopoden-Gebiss aus den mittleren Jura (Bath) Schichten des Mecsek-Gebirges.) 273-276

Soós Árpád: Felhasználható-e a múzeumok rovaranyaga ökológiai vizsgálatokra? (Adatok az Otitidák [Diptera] repülési idejének és egyes fajok nemzedékszámának ismeretéhez). (Die Verwendungsmöglichkeit des Insektenmaterials der Museen zu ökologischen Untersuchungen.) $277-285$

Szunyoghy János: Emlős- és madárbőrök kikészítése tudományos gyüjtemények számára. (Die Präparierung von Bälgen der Säugetiere und Vögel für wissenschaftliche Sammlungen.) 287-296, +2 ábra

Vágás Endre: Mügyanták szerepe a szövettani technikában. [The role of synthetic resins in the cytological methodology.] 297-299

Zimmermann Ágoston: A csontok súlyvesztesége beszáradás következtében. (Über die Gewichtsabnahme der Knochen beim Eintrocknen.) 301-305.

Andrássy István: Walter Rühm: Die Nematoden der Ipiden. (Parasitologische Schriftenreihe, 6. Gustav Fischer Verl., Jena, 1956, pp. 437, 148 ábrával). [Book review.] 307-308

Andrássy István: Curt E. W. Sprehn: Helminthen und Helminthiasen des Schweines (Parasitologische Schriftenreihe, 7. Gustav Fischer Verl., Jena, 1957, pp. 174, 114 ábrával). [Book review.] 308-309

Berczik Árpád: Norman B. Marschall: Tiefseebiologie. Az angol eredetiből fordította és átdolgozta Gerhard Grümmer, Greifswald. (Gustav Fischer Verl., Jena, 1957. pp. 334, 103 szövegközti ábrával és 5 színes táblával). [Book review.] 309-310

Boros István: Knaurs Tierreich in Farben. (Droemer Verlag, München-Zürich). [Book review.] 310-311

Soós Árpád: Győrfi János: Erdészeti rovartan. (Akadémiai Kiadó, Bp., 1957, pp. 670). [Book review.] 311-312

Soós Árpád: A Magyarország állatvilága (Fauna Hungariae) 1957-ben megjelent füzetei. [Book review.] 312-313 
Székessy Vilmos: Móczár László: Rovarok közelről. (Bibliotheca Kiadó, Bp., 1957, 237 oldal, 160 eredeti fényképfelvétellel ill. rajz). [Book review.]

\section{7. kötet - 1959}

\section{1-2. füzet:}

Boros István: Kittenberger Kálmán emlékezete. (In commemoration of Kálmán Kittenberger.) 3-8

Boros István: A Szovjetunió, a népi demokráciák és Finnország zoológusai konferenciájának határozati javaslata. (Declaratory resolution of the conference of zoologists of the Soviet Union, of People's Democracies and of Finland.) 9-16

A magyar állatnevek helyesírási szabályai. [How to write the names of animals in Hungarian.] $17-26$

Ábrahám Ambrus: A vese mikroszkópikus beidegzése. (Mikroskopische Innervation der Niere.) $27-40$

Anghi Csaba Geyza: Az Antonius-féle tigrisló-koponyavizsgálatok értékelése. (Evaluation des examinations des crânes de hippotigrés d'Antonius.) 41-43

Balás Géza \& Mihályi Ferenc: Adatok a fúrólegyek (Trypedidae) magyarországi tápnövényeinek ismeretéhez. (Beiträge zur Kenntnis der Nährpflanzen von Bohr-fliegen (Trypetidae) in Ungarn.) 45-53

Biczók Ferenc: Élettani vizsgálatok a Platyophrya lata Kahl-on II. Contractiós jelenségek. (Physiological examinations on Platyophrya lata Kahl.) $55-61$

Bierbauer József: Adatok a szarvasmarha tejmirigye zsírszöveti állományának fejlődéséhez. (Beiträge zur Entwicklung der Fettgewebssubstanz der Milchdrüse von Kühen.) . 63-64

Erdős József: A rovarpathológia és biológiai védekezés első nemzetközi konferenciája Prágában. (First International Conference of insect pathology and biological control.) 65-68

Gebhardt Antal: Malakofaunisztikai, ökológiai és állatföldrajzi vizsgálatok a Zselicségben (Somogy m.). (Malakofaunistische, ökologische und zoogeographische Untersuchungen im Zselicség (Kom. Somogy, Ungarn).) 69-83

Győrfi János: A nyárfafélék nagylepke károsítói. (Macrolepidoptera pests of poplar trees)

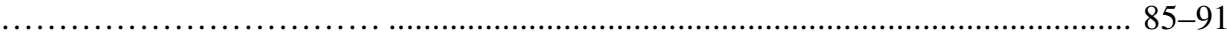

Horváth Imre: $\mathrm{Az}$ idegrendszer experimentális vizsgálata a békák szívén. (Examen expérimental du systéme nerveux effectué sur des coeurs de grenouilles.) 93-97

Horváth Lajos: A Természettudományi Múzeum zoológiai gyüjtőútja Egyiptomban. [The zoological collecting trip of the Hungarian Natural History Museum in Egypt.] . 99-101

Janisch Miklós: A hazai kullancsfauna feltérképezése. (Kartographische Aufnahme der ungarischen Zeckenfauna.) $103-110$ 
Jermy Tibor: A szárazföldi biocönózisok termelésbiológiai vizsgálatának néhány kérdéséről. (Über einige Fragen der produktionsbiologischen Untersuchungen in terrestrischen Biozönosen.) $111-117$

Keve András, Beretzk Péter \& Schmidt Egon: Az egyidejü (synchron) vízimadártani kutatás feladatai és néhány eredménye. (Tasks and some results of synchronous research of water-birds.) 119-124

Lukács Dezső: A bükk-hegységi langyosvízek állatainak ökológiai viszonyai. (Kács-fürdő vizeinek rheobiológiai vizsgálata). (Rheobiologische Untersuchungen der lauwarmen Quellen von Bad Kács im Bükk-Gebirge.) $125-127$

Ponyi Jenőné: A Velencei-tó és környékének víziatkáiról. (Über die Wassermilben des Velencer Sees und seiner Umgebung.) 129-135

Stammer Aranka: Az Amphibiák szemizmainak mikroszkópikus beidegzése experimentális vizsgálatok alapján. (Die mikroskopische Innervation der Augenmuskeln von Amphibien auf Grund experimenteller Untersuchungen.) 137-142

Sterbetz István: A havasi lile (Charadrius morinellus L.) Magyarországon. (Mornellregenpfeifer (Charadrius morinellus L.) in Ungarn.) ......................... 143-147

Stohl Gábor: Vizeletvizsgálatok állatkerti állatokon. (Harnuntersuchungen bei Zootieren.) $149-154$

Szabó István: A herpetofauna védelme külföldön és az erre vonatkozó hazai javaslat. (Protection of the herpeto-fauna abroad and a Hungarian proposition in this respect.) $155-159$

Warga Kálmán: A Kis-Balaton madarainak fészkelő közösségei. (Nistgemeinschaften der Vögel am Kis-Balaton-See.) 161-163

Wéber Mihály: 1957-ben fénycsapdával gyüjtött rovarok mennyiségi értékelése a klimatikus viszonyok figyelembevételével. (Quantitative Auswertung der im Jahre 1957 mit Hilfe von Lichtfallen eingesammelten Insekten unter Berücksichtigung der klimatischen Verhältnisse.) 165-176

Andrássy István: Caesar R. Boettger: Die Haustiere Afrikas. (VEB Gustav Fischer Verl., Jena, 1958, pp. 314). [Book review.] $177-178$

Dudich Endre: Hans Strouhal: Catalogus Faunae Austriae. Ein systematisches Verzeichnis aller auf österreichischem Gebiet festgestellten Tierarten. (Österreichische Akademie der Wissenschaften, Wien). [Book review.] $178-179$

Mihályi Ferenc: A. S. Troschin: Das Problem der Zellpermeabilität. Oroszból németre fordította: Werner Höppner. (VEB Gustav Fischer Verl., Jena, 1953, pp. 396, 118 ábrával és 82 táblával). [Book review.] 180

Farkas Henrik: Szakosztályunk ülései. [Sessions of our section.] $181-185$

3-4. füzet:

Balogh János: Huszonöt év. (Twenty-five years.) $3-7$

Keve András: Herman Ottó a zoológus és ornitológus. (Otto Herman zoologist and ornithologist.) 9-16 
Ambrus Béla: Gubacsok a Kámoni Arborétumból. (Gallen aus dem Arboretum von Kámon.)

Beretzk Péter: A szegedi Fehértó 1958. évi madármozgalma. (Le mouvement des oiseaux du Fehértó de Szeged en 1958.)

Bierbauer József: A magyartarka szarvasmarha tejmirigye normál laktáló állapotának és a laktáció végső fázisának összehasonlítása, szövettani szempontból. (Ein Vergleich zwischen dem normalen Laktationszustand der Milchdrüse des ungarischen Hornviehs und der Endphase der Laktation von histologischem Standpunkt.) 35-37

Boros István: A magyar zoológusok századeleji mimikrivitája mai szemmel. (Hungarian zoologists' controversy on mimicry at the beginning of the present century as seen today.) 39-49

Buchert Ádám: A Microhydra germanica Roch fogókaros polipja és ciklusos fejlődése. (Der Fangarinpolyp der Microhydra germanica Roch und dessen zyklische Entwicklung.) $51-57$

Dózsa István: A hullámos papagáj (Melopsittacus undulatus) fejének csontos váza. (Le squelette osseux de la téte du perroquet Melopsittacus undulatus.) $59-62$

Erdélyi Lajos: Az ingervezető rendszer szerkezete és beidegzése a patások szívében. (Struktur und Innervation des Reizleitungssystems im Herzen der Huftier.) 63-67

Gebhardt Antal: Cönológiai vizsgálatok a Mecsek-hegység patakjai mentén elterjedt Mollusca-állományon. (Cenological examinations of Mollusca found on the banks of the brooks in the Mecsek mountain.) 69-86

Győrfi János: A nyárfák farontólepke ellenségei. (Pappelschädlinge der Schmetterlingfamilien Aegeriidae und Cossidae.) $87-91$

Horváth Lajos: A Természettudományi Múzeum egyiptomi zoológiai gyűjtőútjának madártani eredményei. (The ornithological results of the zoological expedition to Egypt of the Museum of Natural History.) 93-96

Kormos József - Kormos Józsefné: A Suctoriák rajzóstádiumának jelentősége a filogenezisben és a rendszerezésben. (Die Bedeutung des Stadiums des Schwärmers von Suctoria in der Phylogenese und Systematik.) 97-104

Kovács Lajos: A vándorlepkék csoportosítása. (Die Gruppierung der Wanderfalter.) 105-108

Lukács Dezső: Rheobiológiai vizsgálatok a Mellérvölgy-Bővölgy vizeiben. (Examens rheobiologiques dans les eaux des vallons Mellérvölgy-Bővölgy.) 109-117

Móczár László: Az Odynerus spiricornis Spin. (Hym., Eumen.) tevékenysége. (The behaviour of Odynerus spiricornis Spin. (Hym., Eumen.).) $119-123$

Pintér István: Adatok a Dunántúl egyes tájainak Mollusca-faunájához. (Beiträge zur Molluskenfauna einiger Gegenden von Transdanubien.) $125-139$

Steinmann Henrik: Egyenesszárnyú rovarok (Orthoptera) központi idegrendszerének kiemelése, totális festése és összehasonlító vizsgálatának módszerei. (La distraction du système nerveux central des Orthoptères, sa coloration totale et les méthodes de son examen comparatif.) 
Sterbetz István: Szabadföldi és kísérletes megfigyelések a földikutyán (Spalax leucodon Nordm.). (Experimentelle und Freilandbeobachtungen an der Westblindmaus (Spalax leucodon Nordm.).) $151-158$

R. Stiller Jolán: Beszámoló a XIV. nemzetközi limnológiai kongresszusról. (Bericht über den XIV. Internationalen Limnologenkongress.) 159-162

Stohl Gábor: A főemlősök anyagcseréjének sajátosságai. (Characteristics in the metabolism of the primates.) 163-168

Szalay-Marzsó László: Adatok a tarka füzormányos (Cryptorrhynchus lapathi L.) populációdinamikájának és a hazai nemesfüz telepek életközösségének ismeretéhez. (Beiträge zur Kenntnis der Populationsdynamik des Cryptorrhynchus lapathi L. und der Biozönose der Edelweidenbestände.) $169-178$

Szunyoghy János: Az Ovis musimon Pall. honosítása, jelenlegi elterjedése Magyarországon, egyben az Ovis musimon sinesella Turček alfaj bírálata. (Acclimatization and present spreading of Ovis musimon Pall, in Hungary including an evaluation of the subspecies Ovis musimon sinesella Turček.) 179-189

Woynárovich Elek: Halak növekedés-ütemének meghatározása pikkely-évgyürük alapján. (Bestimmung des Wachstumsrhytmus der Fische auf Grund der Anwachsringe.) 191-194

Móczár László: A magyar zoológusok névjegyzéke. (Register of Hungarian zoologists.) 195-204

Boros István: Charles Darwin: Az állatok és növények változásai háziasításuk során I. (Akadémiai Kiadó, Budapest, 1959). [Book review.] 205-206

Balogh János: Cain, A. L.: Die Tierarten und ihre Entwicklung. (Angolból fordította és tdolgozta Dr. rer. nat. habil. Dietrich Ohm, pp. VIII + 280, 1959. VEB Gustav Fischer Verl., Jena). [Book review.] 206

Balogh János: Afred Kaestner: Lehrbuch der Speziellen Zoologie. Teil I.: Wirbellose 3., Lieferung III. (VEB Gustav Fischer Verl., Jena, 1956, pp. 485-658). [Book review.] 207

Kertész György: Alfred Kaestner: Lehrbuch der Speziellen Zoologie. Teil I.: Wirbellose 4., Lieferung IV. (VEB Gustav Fischer Verl., Jena, 1959, p. 659-979). [Book review.] 207-208

Móczár László: W. Hennig: Taschenbuch der Zoologie. Heft 2.: Wirbellose I., ausgenommen Gliedertiere; Heft 3.: Wirbellose II. Gliedertiere. VEB Georg Thieme, Verlag für Medicin und Naturwissenschaften, Leipzig. Heft 2.: 1957, pp. 147; Heft 3.: 1959, pp. 170). [Book review.] 208-209

Szalay László: P. Brohmer: Fauna von Deutschland. Ein Bestimmungsbuch unserer heimischen Tierwelt. 8. javított és bővített kiadás. (Quelle \& Meyer, 1959, pp. XII+651, 1438 ábrával). [Book review.] 209

Szelényi Gusztáv: H. Schmutterer: Schildläuse oder Coccoidea, I. Deckelschildläuse oder Diaspididae. In: Die Tierwelt Deutschlands, Teil 45. (VEB Gustav Fischer Verl., Jena, 1959, pp. 260). [Book review.] 209-210 
Dely Olivér György: A. A. Woitkewitsch: Natürliche Mehrfachbildungen an Froschextremitäten. (VEB Gustav Fischer Verl., Jena, 1959, pp. 82). [Book review.] 210-211

Horváth Lajos: J. Fischer: Geschichte der Vögel. (VEB Gustav Fischer Verl., Jena, 1959, pp. VI + 279). [Book review.] 211-212

Szunyoghy János: N. Atanassow: Der Fuchs (Vulpes vulpes crucigera Bechstein) in Bulgarien. Morphologie, Biologie und wirtschaftliche Bedeutung. (Sofia, 1958, pp. 322. In bulgarischen Sprache, mit russischer und deutscher Zusammenfassung). [Book review.]

Szunyoghy János: N. Atanassow: Untersuchungen über die Schakale (Canis aureus L.) in Bulgarien. (Sofia, 1953, pp. 273. Bulgarisch mit deutscher und russischer Zusammenfassung). [Book review.] 213

Topál György: Szakosztályunk ülései. [Sessions of our section.] $215-223$

\section{8. kötet - 1961}

1-4. füzet:

Keve András: Vasvári Miklós, Vönöczky-Schenk Jakab és Dorning Henrik emlékezete. (In memory of M. Vasvári, J. Vönöczky-Schenk and H. Doming.) 3-9

Szalay László: August Thienemann emlékezete. (Prof. Dr. A. Thienemann zum Gedenken.) $11-14$

Agócsy Pál: Néhány új módszer a malakológiai gyüjtés és kutatás szolgálatában. (Quelques nouvelles méthodes des recherches et de la collection malacologiques.) 15-18

Ambrus Béla: A Köszegi-hegység növényzetének gubacsai. (Les galles dans les collines de Köszeg.) 19-32

Anghi Csaba: Vizsgálatok a látogatók környezethatásának majmokra gyakorolt befolyásáról. (Untersuchungen über die Einwirkung des Umweltseinflusses der Besucher bei den Affen.) 33-36

Dózsa István, Kemenes Ferenc \& Szent Iványi Tamás: Vizsgálatok az emlősök vörösvérsejtjeinek fajmeghatározó szerepéről. (Investigations on the role of red blood corpuscles of mammalians in identifying species.) $37-42$

Gebhardt Antal: A Mohácsi-sziget és az Alsó-Duna árterének Mollusca-faunája, (Danubialia Hungarica, X.). (Die Molluskenfauna eines Überschwemmungsgebietes der Donau und der Mohácsi-Insel.) $43-55$

Jermy Tibor: Fitofág rovarok tájékozódása a fény iránya alapján. (Orientation of phytophagous insects based on the perception of light direction.) …..................... 57-63

Loksa Imre: A Kovácsi-hegy ízeltlábúiról. (Die Arthropoden des Kovácsi-Berges.) .. 65-80

Lukács Dezső: Amphipoda tanulmányok a Bükk-hegységben. (Études sur les Amphipodes de la montagne Bükk.) $81-84$ 
Marián Miklós \& Szabó István: Adatok a mocsári teknős (Emys orbicularis L.) szaporodásbiológiájához. (Contribution to the biology of propagation of the tortoise Emys orbicularis L.)

Móczár László: Kísérletek Odynerus spiricornis Spin.-nal (Hymenoptera: Eumenidae). (Experiments with Odynerus spiricornis Spin. (Hym. Eumen.).) 91-94

Móczár László: A hazai lucernások vadméheinek mennyisége. (The number of wild bees (Hym. Apoidea) in lucerne-fields of Hungary.) 95-105

Molnár Gyula \& Tölg István: Röntgenológiai módszer a fogassüllö (Lucioperca lucioperca L.) gyomoremésztésének vizsgálatára. (Untersuchung der Dauer der Magenverdauung des Zanders (Lucioperca lucioperca I..) mittels einer röntgenologischen Methode.) 107-109

Orbányi Iván: Adatok az európai és amerikai bölény szőrzetének összehasonlító vizsgálatához. (Données á la recherche comparative du pelage de l'aurochs et du bison.) 111-115

Ponyi Jenő: Az alföldi szikes vizek zoologiai kutatásának helyzete. (Zoologische Erforschung der Natrongewässer der Grossen Ungarischen Tiefebene.) $117-124$

Siroki Zoltán: A Saga pedo (Pall.) újabb elöfordulása a Bükk-hegységben. (Ein neueres Vorkommen von Saga pedo (Pall.) im Bükk-Gebirge.) $125-127$

R. Stiller Jolán: Az ásott kutak biológiai vizsgálata. (Biologische Untersuchung gegrabener Brunnen.)

Vásárhelyi István: A Theodoxus danubialis, Fagotia acicularis és Amphimelania holandri újabb hazai lelöhelye. (Neuere Fundorte von Theodoxas danubialis, Fagotia acicularis und Amphimelania holandri (Gastropoda) in Ungarn.) 135-137

Woynárovich Elek - Tölg István: Eszközeink a balatoni halak ivadékainak gyüjtésére. (Die zur Sammlung von íischbrut des Plattensees benützten Geräte.) 139-141

Ujhelyi Sándor: Douglas St. Quentin: Odonata. In: Catalogus Faunae Austriae. Teil XII. (Springer Verlag, Wien, 1959, p. 1-11). [Book review.] 143

Agócsy Pál: Walter Klemm: Mollusca. In: Catalogus Faunae Austriae. Teil VII/a. (Springer Verlag, Wien, 1960, p. 1-59). [Book review.] 143-144

Loksa Imre: Beiträge zur Neotropischen Fauna. Band I., Heft 3. (VEB Gustav Fischer Verl., Jena, 1959, p. 185-268). [Book review.] 144

Andrássy István: Gesa Hartmann-Schröder: Zur Ökologie der Polychaeten des MangroveEstero-Gebietes von El Salvador. In: Beiträge zur Neotropischen Fauna. Band I., Heft 2. (VEB Gustav Fischer Verl., Jena, 1959, p. 69-183, 188 ábrával). [Book review.] 144-145

Andrássy István: Gesa Hartmann-Schröder: Zur Polychaeten-Fauna von Peru. In: Beiträge zur Neotropischen Fauna. Band II., Heft 1. (VEB Gustav Fischer Verl., Jena, 1960, p. 1-44, 92 ábrával). [Book review.] 145

Kaszab Zoltán: Jan Bechyné: Beiträge zur Kenntnis der Alticidenfauna Boliviens (Coleopt., Phytoph.). In: Beiträge zur Neotropischen Fauna. Band I., Heft 4. (VEB Gustav Fischer Verl., Jena, 1959, p. 269-377). [Book review.] $145-146$ 
Kaszab Zoltán: Otto Scheerpeltz: Zur Kenntnis neotropischer Staphyliniden (Col.). In: Beiträge zur Neotropischen Fauna. Band II., Heft 1. (VEB Gustav Fischer Verl., Jena, 1960, p. 65-138). [Book review.] 146

Szalay László: Ingrid Sparing: Die Larven der Hydrachnellae, ihre parasitische Entwicklung und ihre Systematik. In: Parasitologische Schriftenreihe. Band X. (VEB Gustav Fischer Verl., Jena, 1959, pp. 168, 103 ábrával). [Book review.] 146-147

Andrássy István: Peter Krott: Der Vielfrass (Gulo gulo L., 1758). In: Monographien der Wildsäugetiere. Band XIII. (VEB Gustav Fischer Verl., Jena, 1959, p. 1-159, 43 fényképpel). [Book review.] 147-148

Anghi Csaba: Vietinghoff-Riesch: Der Siebenschläfer. (VEB Gustav Fischer Verl., Jena, 1960). [Book review.] 148-149

Sámuel Nicolette: Charles S. Elton: The Ecology of Invasions by Animals and Plants. (Methuen and Co. Ltd., London, 1958). [Book review.] 149-150

Andrássy István \& Topál György: Szakosztályunk ülései. [Sessions of our section.] 151-162

\section{9. kötet - 1962}

1-4. füzet:

Horváth Lajos: Megemlékezés Dr. Nagy Jenőről. (In memory of dr. Jenő Nagy.) .......... 1-2

Szalay László: Dr. H. C. Karl Viets emlékezete. (Dr. H. C. Karl Viets zum Gedenken.) 3-5

Kaszab Zoltán: A magyar faunakutatás helyzete és jövő feladatai. (Present state and future tasks of faunistic research in Hungary.) $7-16$

Székessy Vilmos: Az 1961. szeptember 12. és 14. között Tihanyban és Budapesten tartott faunakutatási symposium határozati javaslata. (Druft proposals submitted to the Symposium of Faunistic Research held 12-14. September 1961 in Tihany and Budapest.) 17-20

Agócsy Pál: A magyarországi bazalthegyek csigafaunájáról I. A Balaton környéki bazalthegyek. (Über die Schneckenfauna der Basaltberge des Balatongebietes.) 21-27

Anghi Csaba: Befejező vizsgálatok a látogatók majmokra gyakorolt környezethatásáról. (Schlußuntersuchungen über die Einwirkung des Umweltseinflusses der Besucher bei den Affen.) 29-33

Berczik Árpád: Kénhidrogén szint, és a hazai eutróf tavak benthosának produkciója. (Schwefelwasserstoffniveau und die Produktion des Benthos in den eutrophen Seen Ungarns.) 35-39

Erdős József: Megfigyelések a Calamagrostis epigeios L.-ben élő rovarok életéről. (Observations super insecta in Calamagrostis epigeios L. viventia.) 41-49

Győrfi János: Nyárfakárosító cincérek. (Capricorn beetles causing injury to poplulars.) $51-54$ 
Iharos Gyula: A Tihanyi-félsziget Tardigrada faunája. (Die Tardigraden-Fauna der Halbinsel Tihany.) $55-61$

Jánossy Dénes: Az első fosszilis vízilóleletek hazánk pleisztocénjéből. (Der erste Nachweis von Hippopotamus antiquus Desmarest, 1822 im ungarischen Altpleistozän (Budapest).)

Keve András: A csigaforgató vonulása a Kárpátmedencében. (Der Zug des Austerfischers im Karpaten-Becken.) .................................................................................... 75-79

Pintér István: A Kovácsi-hegy csigáiról. (Die Schnecken des Kovácsi-Berges.) ......... 81-90

Ponyi Jenő - Ponyi Jenőné: Adatok a Mánfa-patak (Mecsek-hegység) intersticiális faunájának ismeretéhez. (Angaben zur Kenntnis der interstitiellen Fauna des Mänfa-Baches (Mecsek-Gebirge).) 91-96

Sterbetz István: A vörösnyakú lúd (Branta ruficollis Pall.) vonulási problémái KözépEurópában és Magyarországon az utolsó három évtizedben. (Probleme der Züge der Rothalsgans (Branta ruficollis Pall.) in Mitteleuropa und Ungarn in den letzten drei Jahrzehnten.) 97-103

Stohl Gábor: A szarvasmarha néhány élettani sajátosságáról. (Über einige physiologische Eigentümlichkeiten des Rindes) $105-112$

Széky Pál: A halak postembrionális növekedésének vizsgálata röntgenfelvételi technika segítségével. (Examen de la croissance postembryonale des poissons par le moyen de la radiographie.) 113-118

Szunyoghy János: A tanganyikai gyüjtő és vadász expedíción végzett munkám. (Report on the hunting and collecting expedition to Tanganyika and on work performed there.) 119-130

Tölg István: A balatoni fogassüllő táplálékhiányának oka és a táplálékpótlás tervének indoklása. (Die Ursachen des Nahrungsmangels der Zander im Balaton-See und die Begründung des Nährstoffersatzplanes.) $131-140$

Varga Lajos: Kerekesférgek (Rotatoria) a Hoverláról. (Rotatorien vom Hoverla-Berg.) $141-150$

Zicsi András: Táplálkozásökológiai vizsgálatok hazai földigiliszta fajokon. (Ernährungsökologische Untersuchungen an einheimischen Lumbriciden-Arten.) $151-158$

Andrássy István: Arwed H. Meyl: Freilebende Nematoden. In: Die Tierwelt Mitteleuropas, Bd. I., Lief. 5a. (Verlag von Quelle \& Meyer, Leipzig, 1960, pp. 164, 54 táblán 889 ábrával). [Book review.] $159-160$

Szalay László: Kurt O. Viets: Porohalacaridae und Hydrachnellae, Wassermilben. In: Catalogus Faunae Austriae. Teil IX/h. (Springer Verlag, Wien, 1958, p.1-20). [Book review.]

Berinkey László: Paul Kähsbauer: Pisces. In: Catalogus Faunae Austriae. Teil XXI/aa. (Springer Verlag, Wien, 1961, p. 1-56). [Book review.] 160

Dely Olivér György: J. Eiselt: Amphibia, Reptilia. In: Catalogus Faunae Austriae. Teil XXI/ab. (Springer verlag, Wien, 1961, p. 1-21). [Book review.] 
Andrássy István: Lothar Szidat: Versuch einer Zoogeographie des Süd-Atlantik mit Hilfe von Leitparasiten der Meeresfische. In: Parasitologische Schriftenreihe, 13. (VEB Gustav Fischer Verl., Jena, 1961, pp. 98, 54 ábrával). [Book review.] .............. 161-162

Szalay László: Wanda Stojalowska: Krocionogi (Diplopoda) Polski. (Panstwowe Wydawnictwo Naukowe, 1961, pp. 216, 274 szövegábrával). [Book review.] .......... 162

Balogh János: Günter Tembrock: Verhaltenforschung. Eine Einführung in die TierEthologie. (VEB Gustav Fischer Verl., Jena, 1961, pp. 371, 114 ábrával). [Book review.] $162-163$

Tóth János: Erwin Amlacher: Taschenbuch der Fischkrankheiten. (VEB Gustav Fischer Verl., Jena, 1961, pp. 268, 159 ábrával). [Book review.] $163-164$

Horváth Lajos: H. Schildmacher: Beiträge zur Kenntnis deutscher Vögel. (VEB Gustav Fischer Verl., Jena, 1961, pp. 295). [Book review.] 164

Andrássy István: H. Wermuth \& R. Mertens: Schildkröten, Krokodile, Brückenechsen. (VEB Gustav Fischer Verl., Jena, 1961, pp. 422, 271 ábrával). [Book review.] 165

Berczik Árpád: G. A. Smidt: Állatfejlődéstan II. Fordította: Török lászló. (Akadémiai Kiadó, Bp., 1961, pp. 438, 152 ábrával). [Book review.] $165-166$

Zicsi András: E. von Törne: Pedobiologie. (VEB Gustav Fischer Verl., Jena, 1961). [Book review.] 166

Loksa Imre: M. Hartmann: Fortschritte der Zoologie. 13. kötet. (Gustav Fischer Verlag, Stuttgart, 1961, pp. 397, 47 ábrával). [Book review.] 167

Farkas Henrik: Szakosztályunk ülései. [Sessions of our section.] $169-177$

\section{0. kötet - 1963}

1-4. füzet:

Keve András: Csörgey Titus és Breuer György emlékezete. (Memory of Titus Csörgey and György Breuer.) $1-5$

Ambrus Béla: A Kárpát-medence gubacslegyei (Diptera: Cecidomyidae). (Die Gallmücken des Karpatenbeckens (Diptera : Cecidomyidae).) $7-15$

Anghi Csaba: Vizsgálatok a fehér egerek konstitúciós típusairól. [Studies on the consitutetypes of the white mice.] $17-18$

Anghi Csaba: Szemelvények Mongólia állatvilágából. (Über die Tierwelt der Mongolei.) $19-22$

Baranyai Pál, Dózsa István \& Kapus Gyula: Emberi és állati vérfehérjék összehasonlító vizsgálata immunelektrophorézissel. (Comparison of human and animal blood proteins through immune-electrophoresis.)

Bierbauer József: Újabb szövettani vizsgálatok a magyartarka szarvasmarha tejmirigyén. (Neuere histologische Untersuchungen an der Milchdrüse des ungarischen Vleckviehes.) 
Erdélyi Lajos: Problémák az emlősszív efferens beidegzésében. (Die efferente Innervation des Herzens der Säugetiere.) $35-40$

Erdős József: Megfigyelések a hazai füvek fémfürkész gubacsképzőiről és azok gubacsairól. (Observationes de zoocecidiis graminum hungaricorum.) 41-49

Győrfi János: A Lymantria dispar L. parazitái. (Parasites of Lymantria dispar L.) ... 51-54

Hattyasy Dezső: Egyes rágcsálók fogainak idegellátásáról. (On nerve supply of the teeth of certain rodents)

$55-57$

Iharos Gyula: A Bakony-hegység Tardigrada-faunája I.. (Die Tardigraden-Fauna des Bakony-Gebirges, 1.) 59-67, +1 táblázat

Kaszab Zoltán: A Meloidák földrajzi elterjedésének filogenetikai vonatkozásai. (O филогенетических соотношениях географического распространения Мелоид ; Philogenelic relations of geographical distribution of meloids.) 69-74

Kállai László - Tarján Róbert: Az eltérő környezeti feltételek hatása a túzok (Otis tarda L.) lábcsontjainak alakulására. (Effect of divergent environmental conditions on formation of leg-bones of the bustard (Otis tarda L.).) 75-80

Kertész György: Vizsgálatok a Duna magyarországi szakaszának Rotatoria-planktonján. (Untersuchungen am Rotatorien-Plankton des ungarischen Donauabschnittes.) .... 81-88

Lukács Gyula \& Tusnádi Győző: A termelési tényezők kapcsolatának vizsgálata a pontytenyésztés gyakorlatában. (Untersuchung der produktionsbiologischen Faktoren in der Karpfenzucht.) 89-93

Mihályi Ferenc: A Musca larvipara Portsch. hazai előfordulásáról. (Über das Vorkommen der Art Musca larvipara Portsch. in Ungarn.) 95-97

Molnár Gyula \& Tölg István: Kísérletek néhány édesvízi ragadozóhal mechanikai gyomormüködésének megismerésére. (Versuche zum Erkennen der mechanischen Magentätigkeit einiger Süsswasser-Raubfische.) 99-102

Molnár Kálmán: Mono- és digenetikus mételyek halakból. (Mono- and digenelic nematodes from fishes.) 103-107

Orbányi Iván: Vázfehérje hydrolizátumok vizsgálata rendszertani szempontból. (Die Untersuchung von Proleinoid-Hydrolisaten vom methodischen Standpunk) ..... 109-112

Petró Ede: Az Unio tumidus solidus Zel. és az U. pictorum balatonicus Küst. határozó bélyegeinek megbízhatósági vizsgálata. (Untersuchung der Verlässlichkeit der Bestimmungsmerkmale der Muscheln Unio tumidus solidus Zel. und U. pictorum balatonicus Küst.) $113-120$

Richnovszky Andor: Baja és környékének Mollusca faunája. (The mollusc fauna of Baja and environs.)

Sterbetz István: A szegedi fehértavi tájváltozásokkal kapcsolatos madártelepülések. (Umsiedlang der Vögel infolge der landschaftlichen Umwandlung des Szegeder Fehértó.) 129-134

Szabó László Vilmos: A Zámolyi-medence madárélete. (The avifauna of the Zámolybasin.) 135-150 
Széky Pál: A Putorius putorius L. és Putorius furo L. összehasonlító növekedésvizsgálata csontvázméretek alaján. (Vergleichende Wachstumsuntersuchungen an Putorius putorius L. und P. faro L. auf Grund der Skelettmasse.) $151-166$

Szontagh Pál: Adatok a Malacosoma neustria L. hazai életmódjához. (Beiträge zur Lebensweise der Malacosoma neustria L. in Ungarn.) $167-173$

Szunyoghy János: Egy új emlős megjelenése Magyarországon. (Ein neues Säugetier in Ungarn.) 175-179

Warga Kálmán: A budapesti Városliget egykori fülemüle-állománya. (Former nightingale stock of the Budapest City Park.) 181-184

Andrássy István: Móczár László: Az állatok gyüjtése. (Gondolat Kiadó, Bp., 1962, pp. 490). [Book review.]

Andrássy István: Arno Hermann Müller \& Helmut Zimmermann: Aus Jahrmillionen. (VEB Gustav Fischer Verl., Jena, 1962, pp. 409, 290 ábrával). [Book review.] $185-186$

Szelényi Gusztáv: Mauritz Dittrich: Getreideumwandlung und Artproblem. Eine historische Orientierung. (VEB Gustav Fischer Verl., Jena, 1959, 218 oldal, 37 szövegközti ábra). [Book review.] 186

Szalay László: O. Lundblad: Die Hydracarinen Schwedens. II. In: Arkiv för Zoologi, Ser. 2., Bd. 14., Nr. 1. (Kungl. Svenska Vetenskapsakademien, Verlag Almqvist \& Wiksell, Stockholm-Göteborg-Uppsala, 1962, pp. 635, 129 szövegábrával, 240 térképpel, 123 táblán 490 mikroszkópi és 44 termőhely felvétellel). [Book review.] 186-187

Kaszab Zoltán: Gilmour, E. Forest: On the Neotropical Acanthocinini (Coleoptera, Cerambycidae, Lamiinae). Some new Genera and Generic Revisions. In: Beiträge zur Neotropischen Fauna, II. Band, Heft 4. (VEB Gustav Fischer Verl., Jena, 1962, pp. 249-293). [Book review.]

Szalay László: C. Motas, L. Botosaneanu, St. Negrea: Cercetari asupra biologiei izvoarelor si apelor freatice din partea centrala a Cimpiei Romine. (Editura Academiei Republicii Populare Romine, 1962, pp. 366, 138 szövegábrával és 34 fényképfelvétellel). [Book review.] 188

Andrássy István: Kurt Harz: Geradeflügler oder Orthopteren (Blattodea, Mantodea, Saltatoria, Dermaptera) In: Die Tierwelt Deutschlands, 46. Teil. (VEB Gustav Fischer Verl., Jena, 1960, pp. 232, 566 ábrával). [Book review.] $188-189$

Ponyi Jenő: Beiträge zur Neotropischen Fauna. Band II., Heft 3. (VEB Gustav Fischer Verl., Jena, 1961, p. 143-248). [Book review.] 189

Dely Olivér György: Fritz Stopp: Doppelgänger im Tierreich. (VEB Gustav Fischer Verl., Jena, 1962, pp. 120). [Book review.] 189-190

Andrássy István: N. A. Krassilnikov: Diagnostik der Bakterien und Actinomyceten. Németre fordította: Rudolf Witwer. (VEB Gustav Fischer Verl., Jena, 1959, pp. 812, 285 ábrával). [Book review.] 190

Topál György: Szakosztályunk ülései. [Sessions of our section.] 191-202 


\section{1. kötet - 1964}

1-4. füzet:

Anghi Csaba: Lendl Adolf emlékezete. [Memory of Lendl Adolf.] 3-5

Ambrus Béla: Füzeseink gubacslegyei. (Die Diptera als Gallenerzeuger unserer Weidenhaine.) $7-21$

Anghi Csaba: Tájékoztató adatok Mongólia szemidomesztikált emlőseiről. (Über die semidomestizierten Säugetiere Mongoliens.) 23-29

Edelényi Béla: A hazai madarak belső-élősködő férgei II.. (Endoparasitische Würmer heimischer Vögel, II.) $31-48$

Iharos Gyula: A balatoni nádasok bevonatának Tardigradái. (Die Tardigraden des Periphytons der Röhrichte im Balaton-See.) $49-53$

Kaszab Zoltán: Zoológiai kutatóúton Mongóliában. (A zoological research trip in Mongolia.) $55-70$

Lukács Gyula, Tusnádi Győző \& Vanger Éva: A tógazdasági halhúsprodukció növekedése a népesítés és kihelyezési kezdősúly függvényében. (Die Zunahme der Fischfleischproduktion in den Teichwirtschaften als Funktion der Besiedlung und des AuslegungsAnfangsgewichtes.) $71-76$

Murvay Árpád \& Sterbetz István: Populációs hullámzások a Saséri-rezervátum madárvilágában. (Fluctuation of population in the bird fauna of the nature conservation area Sasér.) $77-81$

Orbányi Iván: Emlősök szőrzetének zsírtartalom-vizsgálata. (A study of the grease content of the hairs in mammals.) $83-86$

Petró Ede: A gödöllői dombvidék Mollusca-faunája. (The mollusc fauna in the hilly country of Gödöllő.) 87-97

Pénzes Bethen: Nagyságbeli összehasonlító vizsgálatok hazai és trópusi halak vörösvérsejtjein. (Grössenvergleichs-Untersuchungen in den Erythrozyten von einheimischen und tropischen Fischen.) 99-102

Pénzes Bethen \& Tölg István: A fehér amurhal (Ctenopharyngodon idella Cuv. \& Val.) és a fehér széleshomlokú hal (Hypophtalmichthys molitrix Cuv. \& Val.) magyarországi betelepítése. (Introduction in Hungary of the fish species Ctenopharyngodon idella Cuv. \& Val. and Hypophthalmichtys molitrix Cuv. \& Val.) 103-104

Ponyi Jenő \& Tamás Gizella: Napszakos változások vizsgálata a tihanyi Belső-tó fito- és zooplanktonján. (Untersuchungen der tageszeitlichen Änderungen der vertikalen Verteilung des Phyto- und Zooplanktons des Teiches Belső-tó bei Tihany.) ..... 105-124

Soós Árpád: Milyen pióca fajok várhatók még a magyar faunában? (Leech species to be shown in the fauna of Hungary.) $125-133$

Sterbetz István: A magyar túzok (Otis $t$. tarda L.) természetvédelmi problémái. (The problems concerning the conservation of the Hungarian bustard (Otis t. tarda L.).) 
Szabó István: A Charadrius apricarius altifrons Brehm magyarországi előfordulása. (The occurrence in Hungary of Charadrius apricarius altifrons Brehm.) $141-142$

Dudich Endre: Sebestyén Olga: Bevezetés a limnológiába. (Akadémiai Kiadó, Budapest, 1963, 234 oldal, 56 ábrával és 14 táblával). [Book review.] 143-144

Andrássy István: Dr. Móczár László: Képes állatvilág, I-II. (Móra Ferenc Könyvkiadó, Bp., 256 + 255 oldal, 300-300 fényképpel). [Book review.] $144-145$

Berczik Árpád: Dr. Mihályi Ferenc \& Sztankayné Dr. Gulyás Magdolna: Magyarország csípő szúnyogjai. (Akadémiai Kiadó, Bp., 1963, 229 oldal, 82 ábrával). [Book review.] $145-146$

Andrássy István: Dr. Hans-Albrecht Freye: Repetitorium der Zoologie. (VEB Gustav Fischer Verl., Jena, 324 oldal, 93 ábrával és 30 táblázattal). [Book review.] ..... 146-147

Kondics Lajos: Prof. Dr. Heinz Lüdtke: Praktikum der vergleichenden Zoohistologie. (VEB Gustav Fischer Verl., Jena, 1963, 124 oldal, 121 ábrával). [Book review.] ....... 147-148

Andrássy István: Dr. Alfred Kaestner: Lehrbuch der Speziellen Zoologie. Teil I.: Wirbellose. 5. Lieferung. (VEB Gustav Fischer Verl., Jena, p. 891-1423, 304 ábrával). [Book review.] 148

Andrássy István: Prof. Dr. Lothar Kämpfe: Vergleichende Untersuchungen zur Autökologie von Heterodera rostochiensis Wollenweber und Heterodera schachtii Schmidt. (VEB Gustav Fischer Verl., Jena, 205 oldal, 78 ábrával). [Book review.] .. 149 Iharos Gyula: Franz Mihelcic: Tardigrada. Catalogus Faunae Austriae. [Book review.] $149-150$

Balogh János: Fortschritte der Zoologie. Band 14. (Gustav Fischer Verlag, Stuttgart, 547 oldal). [Book review.]

Berczik Árpád: Fortschritte der Zoologie. Band 15, Heft 1-2. (Gustav Fischer Verlag, Stuttgart, 1962, p. 1-164 és 165-336). [Book review.] $150-151$

Dely Olivér György: Fortschritte der Zoologie. Band 15., Lief. 3., 1962, p. 337-423; Band 16., Lief. 1., 1963, pp. 186. (Gustav Fischer Verlag, Stuttgart). [Book review.] 151-152

Topál György: Szakosztályunk ülései. [Sessions of our section.] $153-163$

\section{2. kötet - 1965}

1-4. füzet:

Dudich Endre: Varga Lajos emlékezete. [In memoriam Lajos Varga.] 3-9

Kovács Gyula: Dr. Zimmermann Ágoston. [In memoriam Dr. Ágoston Zimmermann.] $11-16$

Móczár László: N. Dr. Bajári Erzsébet. [In memoriam N. Dr. Erzsébet Bajári.] $17-19$

Agócsy Pál: Hazai csigafajaink elterjedését megszabó klímatényezők vizsgálata. (Untersuchungen der die Verbreitung der ungarischen Schneckenarten bedingenden klimatischen Faktoren.) 21-27 
Ambrus Béla: A füzhajtásvég-gubacslégy (Rhabdophaga terminalis F. Lw., 1850) biológiája (Diptera, Cecidomyidae). (Biologie der Weidentriebspitzen-Gallmücke Rhabdophaga terminalis F. Lw. (Diptera, Cecidomyidae).) 29-35

Anghi Csaba: Összehasonlító szőrvizsgálatok néhány Mongóliában és a Budapesti Állatkertben élő közös állatfajon. (Vergleichende Haaruntersuchungen an einigen in Mongolien und im Budapester Tiergarten lebenden gemeinsamen Tierarten.) ...... 37-40

Gyurkó István \& Szabó Zsigmond: Adatok a petényi márna (Barbus meridionalis petényi, Heck.) szaporodás-biológiájához. (Beiträge zur Vermehrungsbiologie der Petényischen Barbe (Barbus meridionalis petenyi Heck.).) 41-46

Iharos Gyula: A Bakony-hegység Tardigrada-faunája II.. (Die Targigrada-Fauna des Bakony-Gebirges, II.) 47-56, +1 táblázat

Kaszab Zoltán: Zoológiai kutatóúton a Góbi-Altájban és a Hangáj-hegységben. (On a zoological research trip in the Gobi Altai and the Changai Range.) $57-78$

Kemenes Ferenc: A hazai sünök leptospirózisa és annak járványtani jelentősége. (Die durch Leptospiren verursachten Infektionen von Igeln in Ungarn und deren epizootische Bedeutung.) 79-83

Keve András: A vízityúk (Gallinula chloropus L.) alfajainak rendszertani kérdése. (Some notes on the taxonomy of the Moorhen.) $85-88$

Martinovich Valér: Tápnövény és elterjedési vizsgálatok hazai fúrólegyeken (Diptera, Trypetidae). (Untersuchungen über Wirtspflanzen und Verbreitung der heimischen Bohrfliegen (Diptera, Trypetidae).) 89-94

Mihályi Ferenc: Legyek kinevelése szabadba kitett székletből és húsból. (Die Züchtung von Fliegen aus ins Freie hinausgestellten Fäkalien und Fleisch.) 95-105

Soós Lajos: A Theodoxus fluviatilis L. (Gastropoda, Prosobranchiata) állítólagos előfordulása a Tiszában. (Alleged occurrence of Theodoxus fluviatilis L. (Gastropoda, Prosobranchiata) in the river Tisza.) $107-110$

Szabó László Vilmos: Fészkelő madártársulások vizsgálata a kunmadarasi szikeseken. (The examination of nesting bird associations on the alkali (szik) soils of Kunmadaras.) $111-134$

Szontagh Pál: A Paranthrene tabaniformis Rott. hazai életmódja és károsítása. (Die Lebensweise und Schädigung von Paranthrene tabaniformis Rott, in Ungarn.) 135-142

Vásárhelyi István: Az éticsiga gyüjtéséröl. (Über die Sammlung der Weinbergschnecke.) 143-146

Zicsi András: Beszámoló a kongói talajzoológiai expedíció gyüjtéseiről. (Account on the collection of the soil zoological expedition in the Congo.) $147-153$

Zimmermann Gusztáv: A plica urogenitalisról. (Über die Plica urogenitalis.) ........ 155-158

Stiller Jolán: Gerhard Haider: Monographie der Familie Urceolariidae (Ciliata, Peritricha, Mobilia) mit besonderer Berücksichtigung der im süddeutschen Raum vorkommenden Arten. (In: Parasitologische Schriftenreihe, H. 17. VEB Gustav Fischer Verl., Jena, 1964, pp. IV +251, 104 szövegközti árával és 20 táblázattal). [Book review.] 159 
Szalay László: A. J. Besseling: De Nederlandse Watermijten (Hydrachnellae Latreille, 1802). Monographien van de Nederlandsche Entomologische Vereeniging, No. 1., Amsterdam, 1964, 199 oldal, 333 ábrával). [Book review.] 160

Sámuel Nicolette: H. G. Andrewartha: Introduction to the Study of Animal Populations. (Methuen \& Co. Ltd., London, 1961, pp. 281, 52 ábrával). [Book review.] ...... 160-161

Iharos Gyula: L. Rudescu: Tardigrada. (Fauna R. P. R., 1964). [Book review.] ...... 161-162

Andrássy István: Dr. Günther Tembrock.: Verhaltensforschung. Eine Einführung in die Tier-Ethologie. (VEB Gustav Fischer Verl., Jena, 1964, pp. 521, 121 ábrával). [Book review.] $162-163$

Sámuel Nicolette: John H. Storer: The Web of Life. A First Book of Ecology. (Signet Science Library Book, The New American Library and World Literature, New York, negyedik kiadás, 1963, pp. XII+128, 24 tábla képpel). [Book review.] $163-164$

Dely Olivér György: Dr. Sándor Babos: Die Zeckenfauna Mitteleuropas. (Akadémiai Kiadó, Budapest, 1964, pp. 410, 304 szövegközti ábrával és 7 képtáblával). [Book review.] 164

Ács Tamás: Prof. Dr. Otto Pflugfelder: Lehrbuch der Entwicklungsgeschichte und Entwicklungsphysiologie der Tiere. (VEB Gustav Fischer Verl., Jena, 1962, pp. 347, 430 ábrával). [Book review.] 164-165

Andrássy István: Dr. L. P. Pellérdy: Catalogue of Eimeriidea (Protozoa; Sporozoa). (Akadémiai Kiadó, Budapest, 1963, pp. 160). [Book review.] $165-166$

Topál György: Szakosztályunk ülései. [Sessions of our section.] $167-177$

\section{3. kötet - 1966}

1-4. füzet:

Anghi Csaba: Megemlékezés Dr. Éhik Gyuláról (1891-1965). [In memoriam Dr. Gyula Éhik (1891-1965).]

Kaszab Zoltán: Megemlékezés Dr. Párducz Béláról (1911-1964). (In memoriam Dr. Béla Párducz (1911-1964).) ........................................................................... 7-11

Agócsy Pál: Néhány éticsiga populáció vizsgálata. (Die Untersuchung einiger Weinbergschnecken-Populationen.) ........................................................... 13-19

Anghi Csaba: Újabb koefficiensek az emlősök testfelületének kiszámításához. (Neuere Koeffizienten zur Berechnung der Körperfläche der Säugetiere.) $21-22$

Balás Géza: Adatok a Balatonkörnyék gubacsainak ismeretéhez. (Beiträge zur Kenntnis der Galläpfel der Balatongegend.) 23-31

Benedek Pál: A magyarországi Eurydemákról (Heteroptera, Pentatomidae) II. A hazai Eurydema fajok faunisztikai, etológiai adatai és földrajzi elterjedése. (On the Eurydema species in Hungary (Heteroptera, Pentatomidae). I I . Faunistical and ethological data of Eurydemae in Hungary and their geographical distribution.) $33-41$ 
Berczik Árpád: A Chironomida-kutatás rendszertani problémáiról. (Über die taxonomischen Probleme der Chironomiden-Forschung.) $43-47$

Farkas József: Néhány rovar és atka kártevő sugártürésének vizsgálata. (Die Prüfung der Strahlungstoleranz einiger Insekten- und Milbenschädlinge.) 49-57

Fodor Tamás: Vizsgálatok a túzokról, mesterséges körülmények között. (Examinations of bustard under artificial conditions.)

Hámor Tamás: A sebes pisztráng (Salmo trutta L.) és a szivárványos pisztráng (Salmo irideus Gibbons) ivartermékeinek vizsgálata. (Die Untersuchung der Geschlechtsprodukte der Forellenarien Salmo trutta L. und Salmo irideus Gibbons.)

63-68

Iharos Gyula: A Bakony-hegység Tardigrada-faunája III. (Die Tardigraden-Fauna des Bakony-Gebirges, III.) $69-78$

Jászfalusi Lajos - Papp Károlyné: A tógazdasági ponty táplálékállatai béltartalom vizsgálatok alapján. (Die Nahrungstiere des teichwirtschaftlichen Karpfens auf Grund von Untersuchungen des Darminhaltes.) 79-87

Kaszab Zoltán: Állattani gyüjtőúton Kelet-Mongólia sztyeppéin. (On a zoological collecting trip to the steppes of Eastern Mongolia.) 89-99

Keve András: Ritka madárfajok faunisztikai jelentőségének újabb megítélése. (Neuere Auswertung der faunistischen Bedeutung seltener Vogelarten.) 101-103

Orbányi Iván: Takarmányok áthaladási sebességének megállapítása vadállatoknál. (Die Bestimmung der Durchgangsgeschwindigkeit von Futtermitteln bei Wildtieren) 105-108

Pénzes Bethen - Tölg István: Adatok a fehér amurhal (Ctenopharyngodon idella Cuv. \& Val.) növekedéséhez és táplálkozásához. (Beiträge zum Wachstum und zur Ernährung von Ctenopharyngodon idella Cuv. Val.) 109-113

Ponyi Jenő: A rákok (Crustacea) emésztőrendszerének fehérjebontó enzimeiről. (Über die eiweisszersetzenden Enzyme des Verdauungssystems der Krebse (Crustacea).) $115-122$

Sey Ottó: Adatok a szárcsa (Fulica atra L.) parazita féregfaunájához. (Beiträge zur parasitären Würmerfauna des Wasserhuhns (Fulica atra L.).) $123-130$

Sterbetz István: A nyári lúd (Anser a. rubrirostris Swinh.) természetvédelmi problémái Magyarországon. (The nature conservation of the Greylag Goose (Anser a. rubrirostris Swinh.) in Hungary.) 131-133

Szabó István: Gerincesfaunánk felkutatottságának helyzete. (Die Lage der Erforschtheit der ungarischen Wirbeltierfauna.) 135-139

Szabó János Barna: Sikeres védekezés szakállas szúnyogok (Culicoides nubeculosus Mg., 1818) ellen (Diptera, Nematocera, Ceratopogonidae). (Successful protecting action against Culicoides nubeculosus Mg., 1818 (Diptera, Nematocera, Ceratopogonidae)

Széky Pál: Craniometriás vizsgálatok a vörösróka (Vulpes vulpes L.) koponyáján. (Craniometrical examinations on the skull of the Red Fox (Vulpes vulpes L.).) 
Boros István: Két papagájkönyv: Dr. Hans v. Boetticher: Papageien. (In: Die Neue BrehmBücherei, H. 228. Ziemsen Verlag, Wittenberg-Lutherstadt, 1959, pp. 116, 56 fényképpel); A. Reichenow: Vogelbilder aus fernen Zonen. Papageien. - Dr. Hans v. Boetticher által átdolgozott II. kiadás. (Gottfried Helene Verlag, 1955, 34 színes táblával). [Book review.] $157-159$

Sámuel Nicolette: Peter H. Klopfer: Behavioral Aspects of Ecology. (Prentice-Hall Biological Science Series, Concepts of Modern Biology Series, Englewood Cliffs, New York, pp. XI + 166). [Book review.] 160

Sámuel Nicolette: Dr. Otto Henze \& Dr. Günther Zimmermann: Gefiederte Freunde im Garten und Wald. (Bayerischer Landwirtschatsverlag GmbH, München, 1964, pp. 200, 42 rajzzal, 64 színes felvétellel és 3 színes táblázattal). [Book review.] 160-161

Andrássy István: Prof. Dr. Alfred Kaestner: Lehrbuch der speziellen Zoologie. Band I.: Wirbellose, 1. Teil. (VEB Gustav Fischer Verl., Jena, 1965, 845 oldal, 660 ábrával). [Book review.] $162-163$

Balogh János: Prof. Dr. Wilhelm Kühnelt: Grundriss der Ökologie, mit besonderer Berücksichtigung der Tierwelt. (VEB Gustav Fischer Verl., Jena, 1965, 402 oldal, 141 ábrával). [Book review.] 163

Gere Géza: Wolfgang Tischler: Agrarökologie. (VEB Gustav Fischer Verl., Jena, 1965, pp. 499, 150 szövegközti ábrával és 5 táblázattal). [Book review.] $163-164$

Berczik Árpád: Prof. Dr. Liepolt: Limnologia der Donau. (Schweizerbart'sche Verlagsbuchhandlung, Stuttgart). [Book review.] 164-165

Loksa Imre: Dr. Hans-Eckhard Grunner: Krebstiere oder Crustacea. V.: Isopoda. In: F. Dahl: Die Tierwelt Deutschlands. 1-2. Lief. (VEB Gustav Fischer Verl., Jena; 1. Lief.: 1965, 149 oldal, 119 ábrával, 2. Lief.: 1966, 230 oldal, 143 ábrával). [Book review.] 165-166

Andrássy István: Prof. Dr. Hans-Albrecht Freye: Repetitorium der Zoologie. (VEB Gustav Fischer Verl., Jena, 1965, 327 oldal, 94 ábrával). [Book review.] 166

Andrássy István: Prof. Dr. Lothar Kämpfe, Doz. Dr. Rolf Kittel \& Dr. Johannes Klapperstück: Leitfaden der Anatomie der Wirbeltiere. (VEB Gustav Fischer Verl., Jena, 1966, 322 oldal, 187 ábrával). [Book review.] 167

Schmidt Egon: Prof. Dr. Hans Schildmacher: Wir beobachten Vögel. (VEB Gustav Fischer Verl., Jena, 1965, pp. 400, 348 ábrával). [Book review.] 167-168

Topál György: Szakosztályunk ülései. [Sessions of our section.] 169-179

\section{4. kötet - 1967}

1-4. füzet:

Ambrus Béla: A zsákos gubacslégy biológiája (Putoniella marsupialis F. Lw., Diptera: Cecidomyidae). (Die Biologie der Putoniella marsupialis F. Lw. (Diptera: Cecidomyidae).) 3-11 
Anghi Csaba: Kísérlet a mozgásnak mint jelközlésnek zooszemiotikai értékelésére. (Versuch einer zoosemiolischen Bewertung der Bewegung als Mittel der Signalmanifestation.) $13-21$

Anghi Csaba: Vizsgálatok a jávorszarvas (Alces alces alces L.) tejhozamáról 2. A szőr mint konstitúciós bélyeg. (Untersuchungen über den Milchertrag des Elchtiers (Alces alces alces L.). 2. Die Behaarung als Konstitutionsmerkmal.) 23-27

Benedek Pál: A magyarországi Eurydemákról (Heteroptera, Pentatomidae) V. A hazai Eurydema fajok természetes ellenségei. (On the Eurydema species in Hungary (Heteroptera, Pentalomidae). V. The natural enemies of Hungarian Eurydemae.) . 29-34

Bogsch Ilma: Adatok néhány tengeri faj átlagos akváriumi élettartamáról. (Angaben über die durchschnittliche Lebensdauer einiger Meeretiere im Aquarium.) .................. 35-38

Horváth Cecilia: Az axolotl (Ambystoma mexicanum) spontán hazai metamorfózisa. (Spontaneous metamorphose of axolotl (Ambystoma mexicanum) in our country.) 39-42

Kaszab Zoltán: Zoológiai kutatóúton Nyugat-Mongóliában. (On a zoological collecting trip to the western Mongolia.) 43-62

Kaszab Zoltán: A Przewalski-ló (Equus przewalskii Poljakoff) újabb előfordulása Mongóliában. (Recent occurrence of the Przewalski-horse (Equus przewalskii Poljakoff) in Mongolia.) 63-65

Koppányi Tibor: Zoocönológiai felvételek eredményeinek számszerü összehasonlítása. (Zahlenmässiger Vergleich der Resultate zoozönologischer Aufnahmen.) ............ 67-80

Matolcsi János: A szarvasmarha végtagcsontjainak méretarányai. (Massverhältnisse der Extremitätenknochen des Rindes.) $81-88$

Móczár László: Mocsáry Sándor és a Természettudományi Múzeum Hymenoptera gyüjteménye. (S. Mocsáry und die Hymenoptera-Sammlung des Naturwissenschaftlichen Museums) 89-97

Móczár László: A magyar zoológusok névjegyzéke. [Register of the Hungarian zoologists.]. 99-113

Nagy István Zoltán: Embryológiai és hisztokémiai vizsgálatok kétéltủek chorda dorsalisán. (Embryological and histochemical investigations on the chorda dorsalis of Amphibia.) $115-119$

Péczely Péter: Az eminentia mediana szerepe a madarak mellékveséjének központi szabályozásában. (Die Rolle der Eminentia mediana in der zentralen Regelung der Nebenniere der Vögel.) $121-128$

Ponyi Jenő, Bíró Kálmán \& P. Zánkai Nóra: A Balaton iszaplakó állatainak gyüjtéstechnikája és problémái. (Die Sammeltechnik der schlammbewohnenden Tiere des Balatons und ihre Probleme.) 129-134

Sey Ottó: Szívóférgek a Budapesti Állatkertben tartott adriai halakból. (Trematoden aus den adriatischen Fischarten des zoologischen Gartens von Budapest.) $135-138$

Sinkovits Miklósné \& Széky Pál: Néhány hazai ragadozó emlős haematológiai vizsgálata. (Hämatologische Untersuchungen einiger einheimischer Raubtiere.) 139-145 
Sterbetz István: A kardoskúti Fehértó védetté nyilvánításának első eredményei. (First results of the preservation of the Fehértó (White Lake) of Kardoskút.) $147-150$

Szabó István: A magyarországi emlősállatok bolhái. (On the fleas of Hungarian mammals.) 151-161, +1 táblázat

Szabó János Barna \& Zoltai Nándor: Az 1965. évi több hónapig tartó dunai áradás rovartani tapasztalatai. (Entomologische Erfahrungen des mehrere Monate anhaltenden Donauhochwassers von 1965.) $161-163$

Széky Pál: Allometriai vizsgálatok ragadozó emlősök koponyáján. (Allometrische Untersuchungen am Schädel von Raubtieren.) $165-172$

Szontagh Pál: A kis nyárfacincér (Saperda populnea L.) hazai életmódja és károsítása. (Die einheimische Lebensweise des kleinen Pappelbock (Saperda populnea L.) und seine Schäden.) 173-179

Zimmermann Gusztáv: A plica ductus deferentisről. (Über die Plica ductus deferentis.) $181-185$

Gere Géza: Dr. Imre Loksa: Die bodenzoozönologischen Verhältnisse der FlaumeichenBuschwälder Südostmitteleuropas (Monographie der Flaumeichen-Buschwälder II.) (Akadémiai Kiadó, Bp., 1966, 437 oldal, 105 ábrával, 21 fényképfelvétellel, 62 szövegközti és 76 függelékben elhelyezett táblázattal). [Book review.] $187-188$

Andrássy István: Rolf Keilbach: Die tierischen Schädlinge Mitteleuropas, mit kurzen Hinweisen auf ihre Bekämpfung. (VEB Gustav Fischer Verl., Jena, 1966, 784 oldal, 480 ábrával). [Book review.] $188-189$

Keve András: R. G. Busnel: Acoustic Behaviour of Animals. (Elsevier Publication Comp., Amsterdam-London-New York, 1963, 933 oldal). [Book review.] $189-190$

Andrássy István: W. J. Rees: The Cnidaria and their evolution. in: Symposia of the Zoological Society of London, Nr. 16. (Zoological Society of London, Academic Press, 1966, 449 oldal, számos ábrával és fényképmelléklettel). [Book review.] 190-191

Kaszab Zoltán: G. H. Lohse: Staphylinidae I. (Micropeplinae bis Tachyporinae) In: Freude, Harde \& Lohse: Die Käfer Mitteleuropas. Bd. 4. (Goecke-Evers Verlag, Krefeld, 1964, 264 oldal). [Book review.]

Kaszab Zoltán: Carl von Demelt: II. Bockkäfer oder Cerambycidae I. Biologie mitteleuropäischer Bockkäfer (Col. Cerambycidae) unter Berücksichtigung der Larven. In: Die Tierwelt Deutschlands, 52. Teil. (VEV Gustav Fischer Verl., Jena, 1966, 115 oldal, 9 táblával). [Book review.]

Berczik Árpád: Jürgen Schwoerbel: Methoden der Hydrobiologie (Süsswasserbiologie). (Kosmos Gesellschaft der Naturfreunde, Franck'sche Verlagshandlung, Stuttgart, 1966, 207 oldal, 100 szövegközti ábrával). [Book review.] 192-193

Andrássy István: Miroslav Fendrych: Bibliografie ceskoslovenské parazitologické literatury do konce roku 1961. (Nakladelstvi ceskoslovenské akademie ved, Praha, 1966, 250 oldal). [Book review.] 193-194

Eiben Ottó: Ernst Schubert: Physiologie des Menschen. (VEB Gustav Fischer Verlag, Jena, 1966, 251 oldal, 62 ábrával és 15 táblázattal). [Book review.] 194

Andrássy István: Szakosztályunk ülései. [Sessions of our section.] 195-196 


\section{5. kötet -1968}

1-4. füzet:

Lukács Dezső: Rátz István, az első magyar parazitológus emlékezete, halálának ötvenéves évfordulója alkalmából. [In memoriam István Rátz, the first Hungarian parasitologist, on the $50^{\mathrm{th}}$ aniversary of his death.]

3-8

Szontagh Pál: Megemlékezés Dr. Győrfi Jánosról (1905-1966). [In memoriam Dr. János

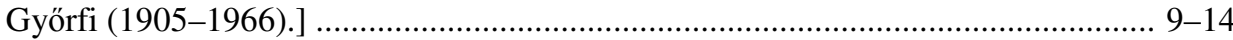

Keve András: Dr. Greschik Jenő emlékezete (1887-1967). [In memoriam Dr. Jenő Greschik (1887-1967).] $15-17$

Keve András: Dr. Darnay-Dornyay Béla és Gajdács Mátyás emlékezete. [In memoriam Dr. Béla Darnay-Dornyay and Mátyás Gajdács.] $19-22$

Anghi Csaba: Vizsgálatok a jávorszarvas tejhozamáról III. A bordaszög és mellkasszelvény mint tejkonstitúciós bélyeg. (Untersuchungen über den Milchertrag des Elches III. Der Rippenwinkel und der Brustkorbquerschnitt als Milchkonstitutionsmerkmale.) . 23-27

Anghi Csaba: Összehasonlító vizsgálatok a jávorszarvas és más patások végtagszögelléseiről. (Vergleichende Untersuchungen des Extremitätenwinkels Elchen und anderen Huftieren.) 29-32

Bíró Kálmán, Ponyi Jenő \& P. Zánkai Nóra: A Balaton nyíltvízi iszapjának nematodái I. A fonálférgek horizontális elterjedése 1966 tavaszán. (Die Nematoden im Schlamm des offenen Wassers des Plattensees I. Die horizontale Ausbreitung der Fadenwürmer im Frühjahr 1966.) 33-35

Jászainé Virág Erzsébet \& Benedek Pál: Az Alloeotomus Fieber nem (Heteroptera, Miridae) magyarországi fajai. (The species of the genera Alloeotomus Fieber (Heteroptera, Miridae) in Hungary.) $37-44$

Kaszab Zoltán: Állattani expedíció a Transzaltáj Góbiba. (A zoological expedition to the Transaltai Gobi.) $45-64$

Legány András: Erdőtelepítések madártani jelentősége. (Die Bedeutung der Anpflanzung neuer Wälder für die Ornithologie.) $65-73$

Nagy István Zoltán: Fejlődéstani és hisztokémiai vizsgálatok madár és emlős embryók gerinchúrján. (Embryological and histochemical examinations on the chorda dorsalis of bird and mammal embryos.) 75-79

Orbányi Iván: Néhány Cervida és Bovida faj hemoglobin típusának meghatározása rendszertani szempontból. (Die Bestimmung der Hämoglobintypen einiger Cervida- und Bovidaarten aus taxonomischer Sicht.) $81-85$

Pénzes Bethen: Magyarországi dévérkeszeg-populációk összehasonlító növekedésvizsgálata. (Vergleichende Untersuchung des Wachstums der Bleie in Ungarn.) 87-96

Pintér István: A magyarországi sapkacsigák (Ancylidae) újabb alakjai. (Neue Formen Ancylidae-Schnecken in Ungarn.) 97-104

Pintér László: A nyugati Pilis puhatestű faunája (Mollusca). (Die Molluskenfauna im westlichen Teil des Pilis-Gebirges.) 105-113 
Póka Géza: Adatok az aranyhörcsög (Mesocricetus auratus) téli ivari életéhez. [Data on the winter sexual life of the golden hamster (Mesocricetus auratus).] $115-117$

Sterbetz István: A magyarországi böjti- és csörgőrécék (Anas querquedula L. és Anas crecca L.) összehasonlító táplálkozásvizsgálata. (The comparative feed-examination of Garganey and Teal (Anas querquedula L. and A. crecca L.) in Hungary.) ...... 119-122

Szontagh Pál: Adatok az Aegeria apiformis Cl. (Aegeridae) hazai életmódjához és károsításához. (Angaben zur Lebensweise und Schädlichkeit der Aegeria apiformis Cl. ( Aegeriidae, Lepidoptera) in Ungarn.) 123-127

Ujhelyi Sándor: Adatok a recésszárnyú rovarok hazai előfordulásához. (Über das einheimische Vorkommen der Neuropteren.) 129-139

Vajon Imre: A barna szemeslepke (Satyrus semele L.) idegrendszerének bonctani viszonyai. (Anatomische Verhältnisse des Nervensystems des Braunen Auglers (Satyrus semele L.).) $141-147$

Wiesinger Márton: Néhány észrevétel a kerti csiga (Cepaea hortensis O. F. Müll.) szentendrei populációjának csíkkombinációiról. (Einige Bemerkungen über die Streifenkombinationen der Population der Gartenschnecken (Cepaea hortensis O. F. Müller) in Szentendre.) $149-157$

Berczik Árpád: Joachim Illies (szerk.): Limnofauna Europaea. Eine Zusammenstellung aller die europäischen Binnengewässer bewohnenden Tierarten mit Angaben über ihre Verbreitung und Ökologie. (Gustav Fischer Verlag, Stuttgart, 1967, XV + 474 oldal, 1 térképmelléklettel). [Book review.] 159-160

Balogh János: Gustav de Lattin: Grundriss der Zoogeographie. (VEB Gustav Fischer Verl., Jena, 1967, 602 oldal, 170 ábrával és 25 táblázattal). [Book review.] 160

Anghi Csaba: V. G. Heptner, A. A. Nasimovic \& A. B. Bannikov: Die Säugetiere der Sowjetunion I. Band. Paarhufer und Unpaarhufer. (VEB Gustav Fischer Verl., Jena, 1966, 939 oldal, 268 ábrával és 6 színes táblával). [Book review.] 161

Kondics Lajos: H. Giersberg \& P. Rietschel: Vergleichende Anatomie der Wirbeltiere. I. (VEB Gustav Fischer Verl., Jena, 1967, 306 oldal, 529 ábrával). [Book review.] $161-162$

Eiben Ottó: D. Starck, R. Schneider \& H.-J. Kuhn: Neue Ergebnisse der Primatologie. (Gustav Fischer Verlag, Stuttgart, 1967, 446 oldal, 183 ábrával). [Book review.] $162-164$

Keve András: Tibor Farkas: Ornithogeographie Ungarns. (Duncker \& Humblot Verlag, Berlin, 1967, 199 oldal, 33 ábrával). [Book review.] 164

Szalay László: David R. Cook: The Water Mites of Liberia. In: Memoirs of the American Entomological Institute, Nr. 6. (The American Entomological Institute, Ann Arbor, Michigan, 1966, 418 oldal, 71 táblán 922 ábrával); David R. Cook: The Water Mites from India. In: Memoirs of the American Entomological Institute, Nr. 9. (The American Entomological Institute, Ann Arbor, Michigan, 1967, 411 oldal, 82 táblán 901 ábrával). [Book review.] 
Eiben Ottó: Helmut Hemmer: Allometrie. Untersuchungen zur Evolution des menschlichen Schädels und seiner Rassentypen. In: Fortschritte der Evolutionsforschung, III. kötet. (Gustav Fischer Verlag, Stuttgart, 1967, 98 oldal, 80 ábrával és 26 táblázattal). [Book review.] $165-166$

Berczik Árpád: Fortschritte der Zoologie. Band 17, Lief. 1-3. (Gustav Fischer Verlag, Stuttgart, 1-188, 189-312, 313-427 oldal). [Book review.] 166

Stohl Gábor: Szakosztályunk ülései. [Sessions of our section.] $167-171$

\section{6. kötet - 1969}

1-4. füzet:

Anghi Csaba: Összehasonlító vizsgálatok a Rangifer tarandus tarandus L., 1758 és a Rangifer tarandus valentinae Flerov, 1933 néhány jellemzőjéről. (Vergleichende Untersuchungen über einige Merkmale von Rangifer tarandus tarandus L., 1758 und Rangifer tarandus valentinae Flerov, 1933.) 3-6

Benedek Pál: A Nabidae család (Heteroptera) fajainak elterjedése a Kárpát-medencében. (Distribution of the species of the family Nabidae (Heteroptera) in the Carpathian Basin.) $7-16$

Beretzk Péter, Keve András \& Marián Miklós: Magyarország zöldikéinek (Carduelis chloris L.) rendszertani kérdései. (Questions of taxonomy of the greenfinches (Carduelis chloris [L.]) of Hungary.) $17-20$

Bierbauer József: Sejttani vizsgálatok a tüdőscsigák (Pulmonata) szemi tapogatójának speciális és szekréciós sejtjein I. (Zytologishe Untersuchungen der speziellen und sekretorischen Zellen an den optischen Tentakeln der Pulmonata.) 21-30

Boros István: Herpetológiai megfigyelések Turkesztánban (1915-1922). (Herpetologische Beobachtungen in Turkestan (1915-1922).) 31-52

Fodor Tamás: A környezeti tényezők értékelése az állatkerti madarak tartásában. (Auswertung der Umweltsfaktoreneffekte bei Haltung von Vögeln im Tiergarten.) $53-58$

Kaszab Zoltán: Állattani gyűjtőúton a mongóliai Nagy Tavakhoz. (Zoological expedition to the Great Lakes of Mongolia.) 59-77

Keve András: A madarak habitat áttörése. (Einige Gedanken zum Durchbruch des Habitats bei den Vögeln.) 79-87

Lukács Dezső: A Diphyllobothrium latum (Linné, 1758) Lühe, 1910 hazai előfordulásairól és parazitás ártalmairól. (Diphyllobothrium latum (Linné, 1758) Lühe, 1910, einheimisches Vorkommen und parasitäre Schädigungen.) 89-97

Matolcsi János: Összefüggések a szarvasmarha élősúlya és lábközépcsontjainak súlya között. (Zusammenhänge zwischen dem Lebendgewicht des Rindes und dem Gewicht seiner Metapodien.) 99-106 
Nagy István Zoltán: Hisztokémiai adatok a Branchiostoma lanceolatum (Pallas) chorda dorsalisának alaktanához. (Histochemical data to the morphology of the chorda dorsalis of Branchiostoma lanceolatum (Pallas).) 107-109

Orbányi Iván: Szérum transzferrin meghatározások rendszertani jelentősége. (Significance in taxonomy of serum transferrin determinations.) $111-114$

Pénzes Bethen: A halak herbivor makro- és mikrofágiájának kialakulása. (Die Ausbildung der herbivoren Makro- und Mikrofagie bei den Fischen.) .............................. 115-116

Richnovszky Andor: Malakológiai vizsgálatok a Velencei-tavon I. (Malacological investigations in Lake Velence, I.) …........................................................ 117-120

Sey Ottó: Galandférgek vadászati-halászati szempontból jelentős madarainkból. (Die Bandwürmer der Vögel, die für Jagd und Fischerei von Bedeutung sind.) 121-129

Sterbetz István: Madárélet a kardoskúti Fehértó aszályos időszakában. (Avifauna in the droughty period of the Kardoskút Preserve.) $131-135$

Szabó István: A magyarországi madarak bolhái. (Bird-fleas of Hungary.) 137-145

Széky Pál: Újabb módszer kisemlősök agykoponya kapacitásának meghatározásához. (Neuere Methode zur Bestimmung der Hirnschädelkapazität bei Kleinsäugetieren.) $147-151$

Stiller Jolán: Heinrich Rainer: Urtiere, Protozoa - Wurzelfüssler, Rhizopoda - Sonnentiere, Heliozoa. Systematik und Taxonomie, Biologie, Verbreitung und Ökologie der Arten der Erde. In: Dahl's Tierwelt Deutschlands und der angrenzenden Meeresteile nach ihren Merkmalen und nach ihrer Lebensweise. (VEB Gustav Fischer Verl., Jena, 1968, 176 oldal, 86 ábrával). [Book review.] $153-154$

Delyné Draskovits Ágnes: R. Fritzsche, H. Geiler, U. Sedlag: Angewandte Entomologie. (VEB Gustav Fischer Verl., Jena, 778 oldal, 240 ábrával, 10 szöveg közötti táblázattal, 24 fényképpel). [Book review.] 154

Szalay László: O. Lundblad: Die Hydracarinen Schwedens. III. In: Arkiv för Zoologi, Ser. 2, Bd. 21, nr. 1. (Kungl. Svenska Vetenskapsakademien, Verlag Almquist \& Wiksell, Stockholm-Göteborg-Uppsala, 1968, 634 oldal, 14 szövegtérképpel, 7 táblán 75 ábrával). [Book review.] 155

Andrássy István: Hermann Giersberg \& Peter Rietschel: Vergleichenden Anatomie der Wirbeltiere. II. Band. (VEB Gustav Fischer Verl., Jena, 1968, 107 ábrával). [Book review.] 156

Eiben Ottó: John L. Jinks: Extrachromosomale Vererbung. In: Grundlagen der modern Genetik, 2. kötet. (Gustav Fischer Verlag, Suttgart, 1967, 174 oldal, 41 ábrával). [Book review.]

Topál György: Szakosztályunk ülései. [Sessions of our section.] 157-164 


\section{7. kötet - 1970}

1-4. füzet:

Szabó István: Hankó Béla emlékezete. [In memoriam Béla Hankó.] $3-10$

Matolcsi János: Hankó Béla háziállattörténeti munkássága. (Die Tätigkeit von Béla Hankó auf dem Gebiet der geschichtlichen Haustierforschung.) ...................................... 11-18

Szontagh Pál: Megemlékezés Tallós Pálról (1931-1968). [In memoriam Pál Tallós (19311968).] $19-22$

Anghi Csaba: Adatok a Rangifer tarandus L., 1758 szőrkonstrukciójához. (Angaben über die Haarkonstitution des Rangifer tarandus L.) 23-30

Bierbauer József: Az érző zóna és a ganglionális rendszer alaktana és müködése a tüdőscsigák szemi tapogatóján. (Morphologie und Funktion der Empfindungszone und des Ganglionalsystems auf den Augententakeln der Lungenschnecken (Pulmonaten).) 31-38

Bíró Péter - Elek László: A Balaton halászata és az utóbbi évek ichthyológiai problémái. (Die Fischerei des Balaton und die ichthyologischen Probleme der letzteren Jahre.)

$39-49$

Bozai József: A barna takácsatka (Bryobia rubrioculus Scheuten, 1857) Magyarországon. (Die Lebensweise von Bryobia rubrioculus Scheuten, 1857 in Ungarn.) $51-65$

Fésüs László: Hogyan értékelhetjük a juhok transzferrin meghatározásának eredményeit? (Wie sind die Transferrinbeslimmungsergebnisse bei den Schafen zu werten?) .... 67-73

Matolcsi János: A háziállatok történetének zoológiai kutatása a Szovjetunióban. (Die zoologische Erforschung der Geschichte der Haustiere in der Sowjetunion.) $75-82$

Matskási István: Az Opisthodiscus diplodiscoides Cohn (Trematodes) neuroszekréciós sejtjeinek vizsgálata. (On the neurosecretory cells of Opisthodiscus diplodiscoides Cohn (Trematodes).) 83-88

Nagy G. Károly: Dobrudzsa védett területeinek fejlödési irányvonala. (Trend of development of Dobrudja's nature reserves.) 89-92

Nagy Sándor: Kártevő lepkék összehasonlító vizsgálata kezelt és kezeletlen gyümölcsösökben. (Vergleichende Untersuchung der schädlichen Lepidopteren in gepflegten und ungepflegten Obstgärten.) 93-106

Orbányi Iván - Fésüs László: Néhány juhfajta jellegének és kialakulásának összefüggése a HbA-gén gyakoriságával. (Der Zusammenhang der Rassenmerkmale und der Entwicklung einiger Schafe mit der HbA-Genhäufigkeit.) $107-112$

Papp Jenő: "A Bakony természeti képe" és a zoológiai kutatások. („Nature-landscape of the Bakony-Mountain" and the zoological investigations.) $113-123$

Richnovszky Andor: A magyarországi Duna-szakasz puhatestű faunájának ökológiai viszonyai. (Die ökologischen Verhältnisse der Molluskenfauna des ungarischen Donauabschnittes.) $125-130$

Sasvári Lajos - Szőke Zsuzsa: Forma és jelentés a kékcinege hangadásában. (Form and meaning in vocalisations of the Blue Tit) $131-137$ 
Sterbetz István: A nagyüzemi háziréce-nevelés hatása állóvizeink madárvilágára. (Die Auswirkung der grosswirtschaftlichen Hausentezucht auf die Avifauna unserer stehenden Gewässer.) 139-143

Stohl Gábor: A pézsmaréce és a házikacsa, valamint ezek különböző hibridkombinációinak összehasonlító vizsgálata. (Vergleichende Untersuchungen an Moschus- und Hausenten sowie deren verschiedenen Hybridkombinationen.) $145-155$

Szító András: Árvaszúnyoglárvák áttelelésével kapcsolatos megfigyelések és kísérletek. (Beobachtungen und Versuche bezüglich der Überwinterung von Zuckmückenlarven.) $157-160$

Vitéz Gáborné: Az évszakos ritmus vizsgálata Isopodák neuroszekréciós rendszerén. (Untersuchung des jahreszeitlichen Rhytmus an dem neurosekretorischen System der Isopoden.) $161-166$

Dudich Endre: Móczár László: Állathatározó. I-II. kötet. (Tankönyvkiadó, Bp., 1969, I. kötet: 722 oldal, ebből 155 fekete-fehér ábratábla, a végén 128 színes és fekete-fehér fénykép; II. kötet: 758 oldal, ebből 138 fekete-fehér ábratábla, a végén 155 színes és fekete-fehér fénykép). [Book review.] $167-168$

Andrássy István: Dr. Dudich Endre \& Dr. Loksa Imre: Állatrendszertan. (Tankönyvkiadó, Bp., 1969, 708 oldal, 363 szövegközti ábrával és 8 színes táblával). [Book review.] $168-170$

Keve András: G. S. Fichter: The Animal Kingdom. Ch. Harper festményeivel. (Golden Press, New York, 1969, 105 oldal, 200 ábrával). [Book review.] 170

Balogh János: Günter Tembrock: Grundriss der Verhaltenwissenschaften. (VEB Gustav Fischer Verl., Jena, 1968, 207 oldal, 82 ábrával). [Book review.] $170-171$

Balogh János: W. Tischler: Grundriss der Humanparasitologie. (VEB Gustav Fischer Verl., Jena, 1969, 178 oldal, 70 képpel és 6 táblával). [Book review.] 171

Balogh János: G. Owen Evans: Proceedings of the 2nd International Congress of Acarology, Sutton Bonington (England), 19th-25th July, 1967. (Akadémiai Kiadó, Bp., 1969, 652 oldal). [Book review.] $171-172$

Jánossy Dénes: Schmidt Egon: Bagolyköpet-vizsgálatok. (A Magyar Madártani Intézet kiadványa, Bp., 1967, 137 oldal). [Book review.]

Dely Olivér György: A Veszprém Megyei Múzeumok Közleményei (Mitteilungen der Museen des Komitates Veszprém). 7. kötet. Szerkesztette: Papp Jenő. (A Veszprém Megyei Múzeumok Igazgatóságának kiadása, Veszprém, 1968, 468 oldal). [Book review.] $172-174$

Topál György: Szakosztályunk ülései. [Sessions of our section.] $175-183$ 


\section{8. kötet - 1971}

1-4. füzet:

Endrődi Sebő: Megemlékezés Frivaldszky Imréről halálának 100. évfordulóján. [In memorian Frivaldszky Imre, on the 100th anniversary of his death.] ....................... 3-5

Lukács Dezső: Paszlavszky József emlékezete. (Erinnerung an József Paszlavszky.) .. 6-12

Soós Árpád: A magyar zoológia soron levő feladatai. (Elnöki megnyitó.) (Die nächstliegenden Aufgaben der ungarischen Zoologie. Eröffnungsrede des Vorsitzenden.) .............................................................................................. 13-16

Balogh János: Beszámoló a dél-amerikai és óceániai magyar talajzoológiai expedíciók munkájáról. (Report on the work of the Hungarian soil-zoological expeditions in South America and the South Sea Islands.) $17-49$

Biczók Ferenc: A magyar protozoológiai kutatások helyzete és feladatai. (Lage und Aufgaben der ungarischen protozoologischen Forschungen.) $50-55$

Bogsch Ilma: Néhány megfigyelés a Tilapia leucosticta Trew. szájköltő halon (Cichilidae). (Einige Beobachtungen über Tilapia leucosticta Trewawas (Pisces, Cichlidae).) . 56-59

Gozmány László: A rendszertani, faunisztikai és állatföldrajzi kutatások mai helyzete és problémái. [The present situation and difficulties of the systematic, faunistical and zoogeographical investigations.] 60-65

Jermy Tibor: Az ökológiai és etológiai kutatások helyzete és problémái. (Lage und Probleme der ökologischen und ethologischen Forschungen.) $66-70$

Matskási István - Mészáros Ferenc - Murai Éva: A balatoni halak heminthológiai vizsgálatának eredményei. (Ergebnisse der helminthologischen Untersuchung der Fische des Balaton.) $71-77$

Mészáros Ferenc: Vizsgálatok a hazai denevérek élősködő fonálférgein (Nematoda). (Untersuchungen über die parasitären Fadenwürmer (Nematoda) der heimischen Fledermäuse.) 78-86

Pénzes Bethen: A klórozott víz hatása az élő halakra. (Die Wirkung des mit Chlor behandelten Wassers auf die lebenden Fische.) 87-89

Pintér László: A magyarországi Daudebardiák (Mollusca). (Die Daudebardien Ungarns.) 90-95

Sasvári Lajos - Szőke Zsuzsa: Az őszapó, a barkós és a függő cinege hangjelzéseinek egyedfejlödése. (The ontogeny of the sound signals of the Long-tailed Tit, the Bearded Tit and the Penduline Tit.) 96-104

Simon Tibor: A csévharaszti természetvédelmi és IBP mintaterület. (The nature reserve and IBP sampling area of Csévharaszt.) $105-111$

Somogyi Péter: Vizsgálatok a Visegrádi-hegység ragadozómadarain. (Untersuchungen an den Raubvögeln des Visegráder Gebirges.) $112-116$

Steinmann Henrik \& Mahunka Sándor: Állattani gyűjtőúton Koreában. [On a zoological collecting trip in Korea.] 117-123 
Sterbetz István: Válságos jelenségek néhány hazai szárnyasvad-populáció dinamizmusában. (Krisenerscheinungen im Dynamismus einzelner Federwildpopulationen Ungarns.) $124-129$

Szabó István: Felhívás a Pilis-hegység zoológiai feltárására. [Call for the zoological survey of the Pilis Mountains.] $130-131$

Szító András: A Chironomus winthemi Goetgh. nevü árvaszúnyog (Chironomidae) hazai előfordulása és gazdasági jelentősége. (Vorkommen und wirtschaftliche Bedeutung der Zuckmücke Chironomus winthemi Goetgh. (Chironomidae) in Ungarn.) $132-135$

Szontagh Pál: Adatok a nagy nyárfacincér (Saperda carcharias L.) hazai életmódjához és károsításához. (Angaben zur einheimischen Lebensweise und zu den Schäden des Großen Pappelbockes (Saperda carcharias L.) in Ungarn.) $136-141$

Varga Zoltán: A szétterjedési centrumok és a szétterjedési folyamat jelentősége a földrajzi izoláció kialakulása és a mikroevolúció szempontjából. [The impotance of the spreading centres and the dispersion regarding isolation and microevolution.] 142-149

Zimmermann Gusztáv: Elvi jelentőségü tulajdonságok a plica urogenitalis kialakulásában. (Prinzipielle Eigenschaften im Aufbau der Plica urogenitalis.) $150-155$

Andrássy István: Különös jelenség: fonálféregben élősködő fonálférgek! (Eine merkwürdige Erscheinung: parasitäre Nematoden in Nematoden.) ................. 156-159

Bankovics Attila: Kiscsér (Sterna albifrons) és kucsmás billegető (Motacilla flava feldeggi) a Csaj-tavon. (Das Brüten der Zwergseeschwalbe am Csaj-See.) 160-163

Beretzk Péter: Madárhírek Szeged környékéről. (Ornithologische Nachrichten aus der Umgebung von Szeged.) 164-165

Bécsy László: Adatok a kígyászölyv [Circaetus gallicus (Gm., 1788)] táplálkozásához. (Angaben zur Ernährung des Schlangenadlers (Circaetus gallicus Gm., 1788).) ..... 166

Gere Géza: A szomjazást türő állatokról. (Thirst tolerating animals.) $167-170$

Sterbetz István: Magevő aprómadarak táplálékválogatása. (Nahrungswahl der samenfressenden Kleinvögel.) $171-172$

Sterbetz István: A nyestkutya (Nyctereutes procyonides Gray, 1834) előfordulása Békésmegyében. (Das Vorkommen des Marderhundes (Nyctereutes procyonides Gray, 1834) im Komitat Békés.) 173

Szabó László Vilmos: A pajzsos cankó (Philomachos pugnax) fészkelése a csákvári réten. (Das Brüten des Kampfläufers (Philomachos pugnax) auf der Wiese von Csákvár) 174-175

Keve András: Miklós D. F. Udvardy: Dynamic Zoogeography. (D. Van Nostrand Co. Ltd., London, 1970, 445 oldal, 175 ábrával, 4 táblával és 14 táblázattal). [Book review.] $176-177$

Andrássy István: Dr. Otto Pflugfeldner: Lehrbuch der Entwicklungsgeschichte und Entwicklungsphysiologie der Tiere. (VEB Gustav Fischer Verl., Jena, 1970, 428 oldal, 456 ábrával és 17 táblázattal). [Book review.] $177-178$ 
Balogh János: Wilhelm Kühnelt: Grundriss der Ökologie. 2. átdolgozott kiadás. (VEB Gustav Fischer Verl., Jena, 1970, 443 oldal, 146 ábrával és 9 táblával). [Book review.]

Balogh János: N. B. Marschall: Aspects of Marine Zoology. (Academic Press Inc., London, 1967, 270 oldal). [Book review.] 178

Balogh János: E. Peter Volpa: Understanding evolution. (W. C. Brown Company Publishers, Dubuque, Iowa, 1967, 160 oldal). [Book review.] 178-179

Eiben Ottó: Lipták Pál: Embertan és emberszármazástan. (Tankönyvkiadó, Bp., 1969, 284 oldal, 148 ábrával). [Book review.] 179

Keve András: Walter Wüst: Die Brutvögel Mitteleuropas. (Bayerische Schulbuch-Verlag, München, 1970, 319 oldal, 263 színes táblával). [Book review.] 179-180

Keve András: Dieter Luther: Die ausgestorbenen Vögel der Welt. (Die Neue BrehmBücherei, 424. szám, A. Ziemsen Verlag, Wittenberg-Lutherstadt, 208 oldal, 42 ábrával). [Book review.] 180

Matskási István: Lothar W. Reimer: Digene Trematoden und Cestoden der Ostseefische als natürliche Fischmarken. Parasitologische Schriftenreihe. Heft 20. (VEB Gustav Fischer Verl., Jena, 144 oldal, 67 ábrával, 56 táblázattal és 3 vázlattal). [Book review.] 181

Dózsa-Farkas Klára: Szakosztályunk ülései. [Sessions of our section.] $182-191$

\section{9. kötet - 1972}

1-4. füzet:

Soós Árpád: Megemlékezés Dr. Dudich Endréről (1895-1971). [In memoriam Dr. Endre Dudich (1895-1971).] 3-15

Keve András: Warga Kálmán (1881-1971) emlékezete. [In memoriam Kálmán Warga (1881-1971).] 16-19

Ambrus Béla: A körterügy-gubacslégy (Apiomya bergenstammi Wachtl.) (Diptera: Cecidomyidae). (Die Birnensproß - Gallmücke (Apiomya bergenstammi Wachtl.) (Diptera: Cecidomyidae).) 20-28

Anghi Csaba: Adatok a víziló tüdőkapacitásához. (Angaben zur Lungenkapazität des Flußpferdes.) 29-35

Bierbauer József \& Molnár Judit: A gametogenesis regulációjának kísérletes befolyásolása tüdőscsigákon a téli álom idején. (Die experimentelle Beeinflussung der Regulation der Gametogenese bei den Lungenschnecken zur Zeit des Winterschlafes.) 36-38

Farkas Károly: A termesztett csiperkegomba (Agaricus bisporus) nematológiai vizsgálatának eredményei. (Ergebnisse der nematologischen Untersuchung des gezüchteten Egerlings (Agaricus bisporus).) 39-48

Hattyasy Dezső: A rágcsálók folytonnövő fogainak orális elzáródása. (The oral obstruction of the ever-growing teeth of rodents.) 49-52 
Horn Péter: A mindkét ivarú guppin (Poecilia reticulata Peters, 1859) mutatkozó új autoszomális domináns mutáció. (Eine neue an beiden Geschlechtern dominante autosomale Mutation des Guppy (Poecilia [Lebistes] reticulata Peters).) ............. 53-59

Matolcsi János: Günter Nobis: Vom Wildpferd zum Hauspferd. Studien zur Phylogenie pleistozäner Equiden Eurasiens und das Domestikationsproblem unserer Hauspferde. (Böhlau Verlag, Köln-Wien, 1971, 96 oldal, 6 tábla, 126 táblázat). [Book review.] .. 60

Jermy Tibor: A peszticidek és a bioszféra. (Egy ökológus töprengései.) (Die Pestizide und die Biosphäre.) $61-66$

Keve András: H. Bub: Vogelfang und Vogelberingung. I. és IV. kötet. Die Neue BrehmBücherei, No. 359 és 409. (Ziemsen Verlag, Wittenberg-Lutherstadt, 1971, 222 és 207 oldal). [Book review.]

Keve András: A Balaton guvat-féléi. (Die Rallen des Balaton.) $67-85$

Kovács Gyula: Somogy-Csurgó és környéke Mollusca-faunája. (Die Molluskenfauna von Csurgó und Umgebung (Komitat Somogy).) 86-94

Matolcsi János: A zoológiai háziállatkutatás állása a budapesti nemzetközi szimpózium tükrében. (Der Stand der zoologischen Haustierforschung im Spiegel des Budapester internationalen Symposions.) 95-105

Oláh János: Aljzatcsere és táplálkozás közötti kapcsolat a Potamophylax rotundipennis Brauer lárvájánál (Trichoptera). (Zusammenhang zwischen Substratwechsel und Ernährung bei den Larven von Potamophylax rotundipennis Brauer (Trichoptera).) 106-110

Orbányi Iván: Kísérletek néhány emlősfaj immobilizálására. (Experiments for the immobilzation of some mammal species.) $111-117$

Sasvári Lajos: V. C. Wynne-Edwards: Animal dispersion in relation to social behaviour. (Oliver \& Boyd, Edinbourgh-London, 1969, 653 oldal, 50 ábra, 10 táblázat). [Book review.]

Dely Olivér György: Ernst Schubert: Praktikum der Physiologie. (VEB Gustav Fischer Verl., Jena, 1969, 199 oldal, 35 ábrával). [Book review.] 118

Sterbetz István: A magyarországi vízivad táplálékbázisa. (Nahrungsbasis des Wassergeflügels in Ungarn) 119-126

Keve András: U. N. Glutz von Blotzheim, K. M. Bauer \& E. Bezzel: Handbuch der Vögel Mitteleuropas. Bd. 4. Falconiformes. (Akademischer Verlagsgesellschaft, Frankfurt a. M., 1971, 943 oldal, 128 ábra, 2 színes tábla). [Book review.] 126

Stohl Gábor - Csontos Géza: A gözüegér és a mezeipocok szaporodásbiológiájának genetikai vonatkozásai. (Über die kausalen Zusammenhänge zwischen Fortpflanzungssystem und Populationsgenetik der Südosteuropäischen Hausmaus und der Feldmaus.) $127-135$

Szabó István: A hazai bolhafajok és gazdaállataik viszonyai. (Relation of Hungarian flea species to their hosts.) $136-148$

Szőke Péter: A széles sávú hangspektrográfia (szonogramok) bioakusztikai-etológiai alkalmazásának bírálata. (Why and when is the application of wide band sonograms in bioacoustics inadequate?) $149-153$ 
Sasvári Lajos: W. H. Thorpe \& o. L. Zangwill: Current problems in animal behaviour. (Cambridge University Press, 1969, 424 oldal, 20 ábra). [Book review.]

Zicsi András: Az aggteleki Baradla-barlang biológiai laboratóriumának munkája. (Die Forschungsarbeit des biologischen Laboratoriums der Aggteleker „Baradla"-Höhle.) $155-160$

Andrássy István: A Magyarországról eddig kimutatott szabadon élő fonálférgek (Nematoda) jegyzéke. (Verzeichnis der in Ungarn bisher nachgewiesenen freilebenden Fadenwürmer (Nematoda).) 161-171

Dely Olivér György: A Vipera berus bosniensis Boettger magyarországi előfordulásáról. (Über das Vorkommen von Vipera berus bosniensis Boettger in Ungarn.) $172-173$

Dely Olivér György \& Stohl Gábor: A kecskebéka (Rana esculenta L.) faji jogosultsága. (Is the edible frog (Rana esculenta L.) an interspecific hybrid?) 174-176

Endes Mihály: A pártásdaru (Anthropoides virgo L.) Magyarországon. [The Demoiselle Crane (Anthropoides virgo L.) in Hungary.] 177

Gere Géza: A lisztmoly hernyók (Ephestia kuehniella Z.) anyagcseréjéröl és vízgazdálkodásáról. (Über den Stoffwechsel und Wasserhaushalt der Mehlmottenlarven (Ephestia kuehniella Z.).) $178-180$

Kozár Ferenc: Újabb adatok hazánk pajzstetű faunájának (Homoptera: Coccoidea) ismeretéhez. [New data to the scale insect (Homoptera: Coccoidea) fauna of Hungary.] $181-182$

Schmidt Egon: Madártani megfigyelések Budaörsön. (Ornithologische Beobachtungen in Budaörs.) 183-184

Dózsa-Farkas Klára: Szakosztályunk ülései. [Sessions of our section.] $185-191$

\section{0. kötet - 1973}

1-4. füzet:

Lukács Dezső: Apáthy István (1863-1922) emlékezete, halálának 50. évfordulóján. (In memoriam István Apáthy (4 ${ }^{\text {th }}$ January $1863-27$ th September 1922) on the $50^{\text {th }}$ anniversary of his death.)

Ábrahám Ambrus: A synapsisok szerkezete a fürgegyík (Lacerta agilis L.) nagyagykérgében. (Die Struktur der Synapsen in der Großhirnrinde der Zauneidechse (Lacerta agilis L.).) 15-24

Ambrus Béla: A szeder és málna gubacslegyei (Diptera: Cecidomyidae). (Gallmücken der Brombeere und Himbeere (Diptera: Cecidomyidae).) 25-37

Andrikovics Sándor: Hidroökológiai és zoológiai vizsgálatok a Fertő hínárosaiban. (Hydroecological and zoological examinations in the pondweed fields of lake Fertő.) 39-50

Anghi Csaba: A körformáció mint ethológiai alapmotívum. (Die Kreisformation, als ethologisches Grundmotiv.) $51-54$ 
Berczik Árpád: A hidrobiológiai kutatások helyzete és feladatai Magyarországon. (Lage und Aufgaben der hydrobiologischen Forschungen in Ungarn.)

Beretzk Péter \& Keve András: A halászsas Magyarországon. (Der Fischadler in Ungarn.) $67-78$

Legány András: Adatok a felső-tiszai erdők madárvilágához. (Beigaben zur Vogelwelt der Wälder entlang der Oberen Theiß.) 79-93

Sey Ottó: A Paramphistomum daubneyi Dinnik, 1962 (Trematodes) petéinek kikelési mechanizmusa. (Der Ausschlüpfmechanismus der Eier von Paramphistomum daubneyi Dinnik, 1962 (Trematodes).) 95-101

Soós Árpád: Az európai szárazföldi piócákról (Hirudinoidea: Xerobdellidae). (On the European landleeches (Hirudinoidea: Xerobdellidae).) 103-109

Sterbetz István: Változó magatartási formák egyes túzokpopulációk ivari kapcsolatában. (Wechselnde Verhaltensformen in den Geschlechtsbeziehungen einzelner Großtrappenpopulationen Ost-Ungarns.) 111-117

Szontagh Pál: Adatok a tölgykárosító tortricidák életmódjához. (Angaben zur Lebensweise der eichenschädigenden Tortriziden (Lepidoptera).) 119-125

Szőke Péter: Madarak akusztikus és viselkedési reakciói rivális hím, illetve tojó magnetofonról visszajátszott hangjára. (Acoustic and behavour responses of birds to the vocalization of rival males and females, reproduced by tape recorder.) $127-140$

Tapfer Dezső: A Pilis madárvilága. (Die Vogelwelt des Pilisgebirges.) 141-149

Urbán Sándor: Madártani vizsgálatok a Pilis-hegységben és a Szentendrei-szigeten. (Ornithologische Untersuchungen im Pilis Gebirge und auf der Insel von Szentendre.) $151-159$

Vojnits András: Az almamoly (Laspeyresia pomonella L.) vagilitásának és diszperziójának vizsgálata. (Untersuchung der Vagilität und Dispersion des Apfelwicklers (Laspeyresia pomonella L.).) $161-164$

Anghi Csaba: A kozármislényi archaeotrichológiai lelet. (Der Archäotrichologische Fund in Kozármislény.) 165-167

Endes Mihály: A hortobágyi székipacsirta (Calandrella brachydactyla Leisl.) populációk kvantitatív vizsgálata. (Quantitative Untersuchung der Kurzzehenlerchenpopulation (Calandrella brachydactyla (Leisl.) auf der Hortobágyer Pußta.) $168-171$

Endes Mihály: Lilebíbic (Chettusia gregaria Pall.) a Hortobágyon. (Der Steppenkibitz (Chettusia gregaria Pall.) auf der Puszta Hortobágy)

Gulyás Pál: A Keratella tropica tropica Apstein (Rotatoria) előfordulása a Velencei-tóban. (Das Vorkommen von Keratella tropica tropica Apstein (Rotatoria) im Velencer See.) 173-174

Schmidt Egon: Adatok néhány fészkelő madárfaj mennyiségi viszonyaihoz a Velencei-tó déli részén. (Angaben über die quantitativen Verhältnisse einiger Brutvogelarten im südlichen Teil des Velencersees.) $175-176$ 
Matskási István: Klaus Odening: Perspektiven der Cercarienforschung. Parasitologische Schriftenreihe, Band 21. (VEB Gustav Fischer Verl., Jena, 1971, 205 oldal, 70 ábra, 11 táblázat). [Book review.] 177

Andrássy István: Gesa Hartmann-Schröder: Annelida, Borstenwürmer, Polychaeta. Die Tierwelt Deutschlands, 58. Teil. (VEB Gustav Fischer Verl., Jena, 1971, 594 oldal, 190 ábra). [Book review.] $177-178$

Kertész György: Dietrich Flössner: Krebstiere - Crustacea: Kiemen- und Blattfüsser (Branchiopoda), Fischläuse (Branchiura). (VEB Gustav Fischer Verl., Jena, 1972, 501 oldal, 201 ábra). [Book review.] 178

Andrássy István: Prof. Alfred Kaestner: Lehrbuch der Speziellen Zoologie. Band I.: Wirbellose. 3. Teil: Insecta. A: Allgemeiner Teil. (VEB Gustav Fischer Verl., Jena, 1972, 272 oldal, 182 ábra). [Book review.]

Wiesinger Márton: Erwin Amlacher: Taschenbuch der Fischkrankheiten für Veterinärmediziner und Biologen. Második, bővített kiadás. (VEB Gustav Fischer Verl., Jena, 1972, 378 oldal, 213 ábra, 9 táblázat és 4 színes tábla). [Book review.] . 180

Dely Olivér György: J. L. Cloudsley-Thompson: The Temperature and Water Relations of Reptiles. (Merrow Publishing Co. Ltd., Watford, 1971, 159 oldal, 4 tábla, 2 táblázat és 15 ábra). [Book review.] $180-181$

Dely Olivér György: Zdenek V. Spinar: Tertiary Frogs from Central Europe. (Publishing House of the Czechoslovak Academy of Sciences, Prague, 1972, 253 oldal, 184 tábla, 15 táblázat és 95 ábra). [Book review.] 181-182

Keve András: Sterbetz István: Vízivad. (Mezőgazdasági Kiadó, Bp., 1972, 204 oldal, 58 ábra, 3 színes tábla). [Book review.] 182

Keve András: H. Heinzel, R. Fitter \& J. Parslow: Pareys Vogelbuch. Fordította és átdolgozta: Prof. G. Niethammer és H. E. Wolters. (Paul Parey Verlag, Hamburg \& Berlin, 1972, 324 oldal, 2255 színes ábra és 585 színes elterjedési térkép). [Book review.] $182-183$

Keve András: Fr. J. Turcek: Birds as Biological Indicators. (Questiones Geobiologicae, 10., Slov. Akad. Vied, Bratislava, 65 oldal). [Book review.] 183

Sasvári Lajos: Approaches to Animal Communication. Szerkesztette: Thomas A. Sebeok és Alexandra Ramsay. (Hague - Paris, 1969). [Book review.] 183-184

Sasvári Lajos: R. A. Hinde: Animal Behaviour. A Synthesis of Ethology and Comparative Psychology. (McGraw-Hill Edition, London, 1969). [Book review.] 184-185

Dely Olivér György: Bogdan Stugren: Grundlagen der allgemeinen Ökologie. (VEB Gustav Fischer Verlag, Jena, 1972, 223 oldal, 3 táblázat és 104 ábra). [Book review.] 


\section{1. kötet - 1974}

1-4. füzet:

Keve András: Dr. Beretzk Péter emlékezete (1894-1973). [In memoriam Dr. Péter Beretzk (1894-1973).] 3-6

Anghi Csaba: Megjegyzések a franko-kantábriai barlangfestményekről. (Bemerkungen zu den Franko-Kantabrischen Höhlenmalereien.) $7-12$

Bognár Sándor, Kerényiné Nemestóthy Klára \& Pénzes Béla: A Rhizoglyphus callae Oudemans Magyarországon. (Rhizoglyphus callae Oudemans in Ungarn.) ........... 13-16

Dely Olivér György: A törékeny gyík (Anguis fragilis Linnaeus) rendszertani és elterjedési problémái. (Systematische und Verbreitungs Probleme der Blindschleiche (Anguis fragilis Linnaeus).) $17-26$

Jakab Béla: A tojáshéj strukturális változása az embrió fejlödése folyamán. (Különös tekintettel az avar- és középkori héjleletek összehasonlító vizsgálatára). (Die strukturelle Änderung der Eierschale während der Entwicklung des Embryos (mit besonderer Hinsicht auf die vergleichende Untersuchung der awarenzeitlichen und mittelalterlichen Schalenfunde).) .................................................................. 27-31

Kiss J. Botond: Adatok a Sacalin-sziget emlősfaunájához. (Angaben über die Säugetierfauna der Insel Sacalin.) 32-34

Kovács Gyula: Békéscsaba és környéke puhatestű faunája (Mollusca). (Die Malakofauna von Békéscsaba und Umgebung.) $35-41$

Legány András: A nemesnyárasok (Populeto cultum) madártani viszonyai. (Die ornitologischen Verhältnisse der Edelpappelwälder (Populeto cultum).) ............... 42-48

Lukács Dezső: A 100 éves nápolyi Zoológiai Állomás (Acquario) és a magyar kutatók. (Die 100 jährige Zoologische Station von Neapel (Acquario) und die ungarischen Forscher.) 49-66

Móczár László \& Ferencz Magdolna: A magyar zoológusok névjegyzéke. (Register of the Hungarian zoologists.) $67-85$

Papp Jenő: Az Apanteles Först. fajok rendszerezéséről, különös tekintettel a magyarországi fajokra (Hymenoptera, Braconidae: Microgasterinae). (On the classification of the species Apanteles Först. with special respect to the species living in Hungary (Hym. Braconidae: Microgasterinae).) $86-100$

Papp László: Dipterológiai vizsgálatok nagyüzemi sertéstelepeken. (Dipterologische Untersuchungen in Schweinemastanstalten.) 101-109

Pénzes Bethen: A Velencei-tó halfaunájának alakulása néhány új faj betelepítésével kapcsolatban. (Die Gestaltung der Fischerfauna des Velencer Sees im Zusammenhang mit dem Einsetzen einiger neuer Arten.) $110-116$

Schmidt Egon: Pele előfordulási adatok bagolyköpetekből. (Schläferfunde aus Eulengewöllen in Ungarn.) $117-118$ 
Szabó Elek - Járfás József: Fényre repülő rovarrendek mennyiségi viszonyai és a klimatikus tényezők kapcsolata. (Die quantitativen Verhältnisse der dem Lichte Zufliegenden Insektenordnungen und die Verbindung der klimatischen Faktoren.) 119-132

Sziráki György: Vizsgálatok az Anobium punctatum De Geer ökológiájával és élettanával kapcsolatban. (Examinations on the biology and physiology of Anobium punctatum De Geer I. optimal climatic conditions for the rearing of the larvae.) 133-136

Varga András: Adatok a Keleti-Cserhát puhatestü faunájához. (Angaben zur MolluscaFauna des Östlichen Cserhát-Gebirges.) 137-141

Vargha Béla: Adatok a szövőpintyek (Estrildidae) életmódjához és tartásához. (Zoologische, zootechnische Probleme sowie Ergebnisse bei der Haltung der Estrildiden.) $142-150$

Vargáné Palotás Klára: A Dongér-tó és környéke madárvilágáról. (Über die Vogelwelt des Dongér-Sees und seiner Umgebung.) $151-156$

Andrássy István: Dr. Dudich Endre és Dr. Loksa Imre: Állatrendszertan. (Tankönyvkiadó, Budapest, 1971, 708 oldal, 363 szövegközti ábra és 8 színes tábla). [Book review.] . 157

Pellérdy László: A. Geus: Sporentierchen, Sporozoa. Die Gregarinida. Die Tierwelt Deutschlands, 57. Teil. (VEB Gustav Fischer Verl., Jena, 1969, 606 oldal, 338 ábra). [Book review.] 158

Sasvári Lajos: Peter Marler és William J. Hamilton: Mechanisms of Animal Behavior. (John Wiley and Sons, New York, 1969, 771 oldal). [Book review.] 158-159

Keve András: U. N. Glutz von Blotzheim, K. M. Bauer und E. Bezzel: Handbuch der Vögel Mitteleuropas. Bd. 5. Galliformes und Gruiformes. (Akademische Verlagsgesellschaft, Frankfurt a. M., 1973, 700 oldal, 100 ábra, 5 színes tábla). [Book review.] 159

Keve András: R. M. Mengel: A Catalogue of the Ellis Collection of Ornithological Books in the University of Kansas Libraries. I. A-B. (Lawrence, Kansas, 1972, 259 oldal). [Book review.] 159

Andrikovics Sándor: Szakosztályunk ülései. [Sessions of our section.] $160-164$

\section{2. kötet - 1975}

1-4. füzet:

Lukács Dezső: Emlékezés Daday Jenőre. (Commemoration of Jenő Daday.) $3-13$

Csutorné Bereczky Magdolna: Az áramlási sebesség és a vízállás változásának hatása a Duna planktoni Ciliata-populációjának alakulására. (Danubialia Hungarica, LXXVI). (Einfluss der Stromgeschwindigkeit und der Änderungen des Wasserstandes auf die Gestaltung der planktonischen Ciliatenpopulation der Donau.) $15-21$

Fodor Tamás: A magyarországi túzokpopulációk területi megoszlása, kor és ivar szerinti összetétele 1973-ban. (Gebietsmäßige Verteilung der Ungarischen Grosstrappenpopulationen nach Alters- und Geschlechtszusammensetzung im Jahre 1973.) 23-29 
Harka Ákos: A halállomány vizsgálata a Tisza II körzetében. (Die Untersuchung des Fischbestandes im Bereich der Wasserstufe II der Theiß.) $31-50$

Izrael Gábor: A hazai muflonpopulációk értékelése. (Wertung des Ungarischen Mufflonbestandes.) $51-58$

Lombai János \& Karner István: Magyarországi mezeinyúl-populációk vizsgálata DDT-re, HCH-ra és azok bomlástermékeinek maradékára. (Die Untersuchung der Ungarischen Feldhasenpopulation auf DDT, HCH und auf die Überreste ihrer Abbauprodukte.) 59-67

Murai Éva, Sugár László \& Hőnich Miklós: Vadászterületeinken előforduló galandférgek I. Taeniidae-fajok lárvái. (The tapeworms of the mammals hunted in Hungary I. Larvae of the species Taeniidae.) 69-73

Nagy Mária \& Havasi András: Beszámoló a Gallus domesticus toll-fejlődésével és növekedésével kapcsolatos vizsgálatokról. (Bericht über die Entwicklungs- und Wachstumsuntersuchungen der Feder bei Gallus domesticus.) 75-82

Nagy Sándor: Fénycsapdás vizsgálatok lepkekártevőkre almáskertekben. (Lichtfallenuntersuchungen von Schmetterlingsschädlingen in Apfelgärten.) ....... 83-89

Rakonczay Zoltán: A magyar természetvédelem helyzete és távlati programja. (The present situation and future programme of Hungarian nature conservation.) 91-95

Richter Ilona - Móczár László: Apáthy István és a 100 éves nápolyi Zoológiai Állomás. (István Apáthy und die 100 jährige Zoologische Station zu Neapel.) 97-99

Somfalvi Ervin: Adatok Telki község környékének madárfaunájához. (Angaben zur Vogelfauna in der Umgebung der Ortschaft Telki.) $101-105$

Sterbetz István: Adatok a Mártélyi Tájvédelmi Körzet emlős- és halfaunájához. (Angaben zur Säugetier- und Fischfauna des Naturschutzrayons von Mártély.) $107-114$

Sugár László \& Mészáros Ferenc: Szarvasfélék kötőszövetében élősködő filáriák előfordulása Magyarországon. (Das Vorkommen von schmarotzenden Filarien im Bindegewebe der Hirsche in Ungarn.) $115-117$

Szabó István: Bolhák (Siphonaptera) gyüjtése, preparálása és bolhagyüjtemények felállítása. (Collection and preparation of fleas - setting up flea collections.) 119-128

Szontagh Pál: Az Agrilus suvorovi populneus Schaef. (Coleoptera, Buprestidae) hazai életmódjáról és károsításáról. (Über die Lebensart und Schädigungen von Agrilus suvorovi populneus Schaef. (Coleoptera: Buprestidae).) 129-134

Beretzk Péter: Egyes madárfajok elszíneződése. (Verfärbung einzelner Vogelarten.) 135-137

Horváth Lajos: A keleti nagy őrgébics (Lanius excubitor homeyeri Cabanis) első előfordulása Magyarországon. (The first occurrence of the Eastern Great Grey Shrike (Lanius excubitor homeyeri Cabanis) in Hungary.) 139-141

Sterbetz István: Alföldi tanyák, tanyaromok emlős- és madárvilágának változásai. (Änderungen in der Säugetier- und Vogelfauna der Gehöfte und Gehöftruinen des Alföld.) 143-147 
Horváth Lajos: Eckhard H. Hess: Imprinting early experience and the developmental psychobiology of attachement. (Van Nostrand Reinhold Co., New York, Cincinnati, Toronto, London és Melbourne, 1973, XV + 472 oldal). [Book review.] 149

Rékási József: J. Zlotorzycka, Wd. Eichler és H. W. Ludwig: Taxonomie und Biologie der Mallophagen und Läuse mitteleuropäischer Haus- und Nutztiere. (VEB Gustav Fischer Verl., Jena, 1974, 160 oldal, 73 ábra). [Book review.] $149-150$

Zombori Lajos: Kurt K. Günther: Staubläuse, Psocoptera. Die Tierwelt Deutschlands, 61. Teil. (VEB Gustav Fischer Verl., Jena, 1974, 314 oldal, 437 ábra). [Book review.] $150-151$

Ambrus Béla: Marcela Skuhravá és Václav Skuhravy: Gallmücken und ihre Gallen auf Wildpflanzen. (Die Neue Brehm-Bücherei, A. Ziemsen Verl., Wittenberg-Lutherstadt, 1973, bővített kiadás, 118 oldal, 95 ábrával és 10 táblával). [Book review.] 151

Gere Géza: Székessy Vilmos: Magyarország állatvilága - Fauna Hungariae, XXI. kötet. Aves - Madarak. (Akadémiai Kiadó, Budapest, 1973.). [Book review.] $151-152$

Keve András: Dolgusin, I. A. és munkatársai: Pticü Kazahsztana. I-V. (Akad. Nauk Kazah SzSzR, Alma ata, 1960, 1962, 1970, 1972 és 1974; $470+780+647+367+480$ oldal, $190+392+273+195+142$ ábra). [Book review.] $152-153$

Gere Géza: Harry Kronberger: Haltung von Vögeln, Krankheiten der Vögel. (VEB Gustav Fischer Verl., Jena, 1973, 316 oldal, 49 ábra). [Book review.] 153

Dely Olivér György: Rolf Berg: Angewandte und topographische Anatomie der Haustiere. (VEB Gustav Fischer Verl., Jena, 1973, 416 oldal, 200, többnyire színes ábra). [Book review.] $153-154$

Kádár Zoltán: J. Dorst és P. Dandelot: Säugetiere Afrikas. Fordította és átdolgozta: H. Bohlken és H. Reichstein. (Paul Parey Verl., Hamburg és Berlin, 1973, 252 oldal, 310 ábrával és 214 elterjedési térképpel). [Book review.] $154-155$

Hörömpöly Miklós: Papp József: A Bakony állattani bibliográfiája - Zoologische Bibliographie des Bakony-Gebirges. (Veszprém Megyei Múzeumi Igazgatóság kiadása, Veszprém, 1971, 233 oldal). [Book review.] 155

Papp László: Szakosztályunk ülései. [Sessions of our section.] $157-163$

\section{3. kötet - 1976}

\section{1-4. füzet:}

Lukács Dezső: Ifj. Entz Géza születésének 100. évfordulójára. (Zur 100 jährigen Jahreswende des Geburtstages von G. Entz Jun.) $3-14$

Ábrahám Ambrus: Elektronmikroszkópos vizsgálatok a házikacsa ceromáján, különös tekintettel a Grandry-féle testekre. (Electron microscopic examinations on the ceroma of the duck with special regard to Grandry's corpuscles.) 15-37

Anghi Csaba: Bonobó Budapesten? (Ein Bonobo in Budapest?) 39-42 
Balogh János: A prekambrium jelentősége az élővilág evolúciójában. [The importance of Precambrium in the evolution of life.] 43-49

Bencze Gábor: Az imágókorongok fejlődésében hibás mutáns Drosophila törzsek előállítása és előzetes jellemzése. (The production and preliminary characterization of Drosophila strains faulty in the development of the imago discs.) $51-59$

Bozsko Szvetlana: A balkáni gerle (Streptopelia decaocto Friv.) expanziója a Szovjetunió területén. (Die Expansion der Türkentaube (Streptopelia decaocto Friv.) im Gebiete der Sowjetunion.) $61-65$

Fodor András, Bencze Gábor, Vincze Éva \& Tábith Klára: Kondicionált letálmutánsok alkalmazása a Drosophila fejlődésgenetikájában. (The application of conditioned lethal mutants in the evolution genetics of Drosophila.) $67-77$

Kasza László: Vizsgálatok a csimpánzok szín- és formaérzékével kapcsolatban. (Untersuchungen im Zusammenhang mit dem Farben- und Formensinn der Schimpansen.) $79-81$

Keve András: Gondolatok a madarak urbanizációs kérdéséhez. (Gedanken zur Urbanisationsfrage der Vögel.) 83-94

Kiss István \& Hules Helga: A genetikai mozaicizmus felhasználása Drosophila fejlődési mutánsok jellemzésében. [Application of genetic mosaicism in characterisation of Drosophila developmental mutants.] 95-100

Maróy Péter \& Vargha János: A vedlési hormon vizsgálata Drosophila melanogaster elöbábokban. [Study of the ecdysis-hormon in living pupae of Drosophila melanogaster.] 101-102

Murai Éva \& Sugár László: Vadászterületeinken előforduló galandférgek II. Taeniidae fajok ragadozókból: újabb cysticercosis és echinococcosis esetek. (The tapeworms of mammals in Hungary, II. Species of Taeniidae from predatory animals, further cases of cysticercosis and echinococcosis.) $103-115$

Muschinek Györgyi: Rézvegyületek táplálkozást gátló hatása a káposzta-bagolylepke (Mamestra brassicae L.) hernyóira. (Antifeeding effect of copper compounds on the larvae of the cabbage moth (Mamestra brassicae L., Lepidoptera: Noctuidae).) 117-122

Pénzes Bethen: Vizsgálatok az 1975. évi balatoni halpusztulással kapcsolatban. (Untersuchungen der Ursachen des Fischtodes im Balaton vom Jahre 1975.) ... 123-130

Sáringer Gyula: A fotoperiódus, a hőmérséklet és a táplálék minőségének hatása néhány kártevő lepkefaj diapauzájára és fekunditására. (Die Auswirkungen der Photoperiode, der Temperatur und der Nahrungsqualität auf die Diapause und Fekundität einiger schädlicher Schmetterlingsarten.) 131-139

Sterbetz István: A magyarországi túzokvédelem első eredményei. (Die ersten Ergebnisse des Schutzes der Großtrappe (Otis t. tarda L.) in Ungarn.) $141-145$

Szabó István: A magyarországi Siphonaptera-kutatások múltja és jövő feladatai. (The past and the future tasks of Hungarian Siphonaptera research.) …........................... 147-153

Szelényi Gusztáv: Quo vadis zoocönológia? (Quo vadis Zoozönologie?) ................ 155-160 
S. Szigethy Anna: Anatómiai bélyegek rendszertani értékének megbízhatósági vizsgálata a Helicidae (sensu lato) családban I. A penispapilla. (Zuverlässigkeitsuntersuchung des systematischen Wertes der anatomischen Merkmale bei der Fam. Helicidae I. Die Penispapille.) 161-194

Varga Zoltán: A palearktikus boreális fauna állatföldrajzi tagolódása. (Zoogeographische Gliederung der paläarktischen Borealfauna.) 195-209

Varjas László, Paguia, Pilar \& Wilde, Jan de: A hemolimfa juvenilhormon-titere a káposztalepke (Pieris brassicae L.) és a káposzta-bagolylepke (Mamestra brassicae L.) hernyóiban a lárva-báb átalakulást megelőző fejlödési szakaszban. (Der Juvenilhormontiter der Hämolymphe in den Raupen von Pieris brassicae L. und Mamestra brassicae L. (Lepidoptera) in der Entwicklungsphase vor der Verwandlung der Larve zur Puppe.) 211-217

Andrássy István: A nematológiai kutatások hazai úttörői: Örley László és Daday Jenő. [Pioneers of the Hungarian nematodological research: László Örley and Jenő Daday.] 219-224

Balogh János: A környezetvédelem biológiai alapjai. [The biological bases of the protection of environment.] $225-228$

Endes Mihály: A kucsmás billegető (Motacilla flava feldeggi Mich.) Magyarországon. (Die Maskenstelze (Motacilla flava feldeggi Mich.) in Ungarn.)

Pintér István: Egy Magyarországra nézve új csigafaj: Helicodiscus singleyanus (Pilsbry) (Gastropoda: Endodontidae). (Helicodiscus singleyanus (Pilsbry), eine für Ungarn neue Schneckenart (Gastropoda, Endodontidae.) 231-234

Schmidt Egon: Kisemlősök a macskabagoly (Strix aluco L.) hazai étlapján. (Einige Bemerkungen zu der Säugernahrung des Waldkauzes (Strix aluco L.) in Ungarn) 235-236

Szőcs Gábor: A kis téliaraszoló (Operophtera brumata L.) életmódja. [Living of the winter moth (Operophtera brumata L.).] 237-238

Matolcsi János: A. T. Clason: Archaeozoological studies. (New Holland Publishing Co., Amsterdam, 1975, 477 oldal). [Book review.]

Papp Jenő: M. Fischer: Index of World Opiinae (Hymenoptera, Braconidae). (In: Index of Entomophagus Insects; Le Francois Kiadó, Paris, 1971, 100 oldal). [Book review.] 239-240

Papp Jenő: R. D. Shenefelt: Braconidae, 2., 3., 4. Hymenopterorum Catalogus; nova editio, pars 5., 6., 7. (Dr. W. Junk Verlag, 1970; 1970; 1972, p. 177-668). [Book review.] 240-241

Keve András: U. N. Glutz v. Blotzheim: Handbuch der Vögel Mitteleuropas. Bd. 6. Charadriiformes. 1. Teil. (Akademie Verlagsgesellschaft, Wiesbaden, 1975, 840 oldal). [Book review.] 241-242

Rékási József: Enciclopedia degli uccelli d'Europa. I-III. kötet. (Rizzoli Kiadó, Milano, 1971, 536 + 414 + 464 oldal, számos rajzzal, elterjedési térképpel és fényképpel). [Book review.] 
Keve András: G. Zink: Der Zug europäischer Singvögel. Ein Atlas der Wiederfunde beringter Vögel. (Vogelwarte Radolfzell am Max Planck Institute für Velhaltungsphysiologie, Konstanz, Lieferung 1 und 2, 1973, 1975, pp. $114+117$ ). [Book review.] 243

Papp László: Szakosztályunk ülései. [Sessions of our section.] $245-251$

\section{4. kötet - 1977}

1-4. füzet:

Keve András: Máté László (1893-1976) emlékezete. [In memoriam László Máté (18931976).]

Ábrahám Ambrus: Ultrastruktúra vizsgálatok Herbst-féle testeken. (Examinations of ultrastructure on Herbst's corpuscles.) ............................................................... 7-30

Bierbauer József: Az opticus tentaculumnak mint endocrin szervnek összefüggése a gametogenezis regulációjával. (The connection of the optic tentacle as endocrine organ

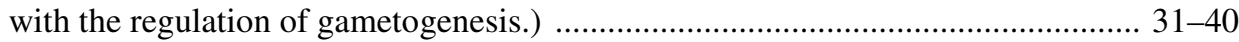

Endes Mihály: A sarkantyús sármány (Calcarius lapponicus [L.]) Magyarországon. (Die Spornammer (Calcarius lapponicus) in Ungarn.) ............................................... 41-44

Harka Ákos: A süllő (Stizostedion lucioperca L.) növekedése a Tisza tiszafüredi szakaszán. (Das Wachstum des Hechtbarsches (Stizostedion lucioperca L.) im Theißabschnitt bei Tiszafüred.).) 45-53

Homonnay Zsombor, Karner István \& Wöller László: Adatok a Fusarium graminearum által termelt F-2 toxin tartalmú takarmány etetésének Cervidae-fajok hímjeire gyakorolt hatásához. (Data on the effect of feeding fodder containing toxin F-2 produced by Fusarium graminearum upon the males of the Cervidae species.) $55-64$

Horvatovich Sándor: Jugoszláviai magashegységek Nebria-faunájának taxonómiai és állatföldrajzi problémái. (Taxonomische und Verbreitungsprobleme der Nebria-Fauna Hochgebirgen in den Jugoslawiens.) $65-71$

Izrael Gábor: Adatok a muflonszarv morfológiájához és növekedésének törvényszerüségeihez. (Angaben zur Morphologie des Mufflonhornes und zu den Gesetzmäßigkeiten seines Wachstums.) 73-90

Jakab Béla: Magyarország gólyaállománya. (Az 1974. évi állományfelvétel eredménye). (Der Storchbestand in Ungarn (Ergebnisse der Bestandsaufnahme im Jahre 1974).)

91-102

Karner István - Wöller László - Nedelkovits János: A Fusarium graminearum gomba által termelt toxinnal fertőzött kukorica etetése házi- és mezeinyulakkal. (Feeding maize infected with toxin produced by the fungus Fusarium graminearum to rabbits and hares.) $103-107$

Kasza László: Hármas csimpánzikrek születtek a Veszprémi Állatkertben. (Chimpanzee triplets born in the Veszprém Zoological Garden.) 109-114 
Legány András \& Vértes Imréné: Egy modellként választott erdő madáregyüttesének kutatási eredményei. (Forschungsergebnisse eines Vogelbestand aus einem als Modell ausgewählten Wald.) $115-127$

Márialigeti Károly: Adatok a földigiliszták bakteriológiájához I. Vizsgálatok az Eisenia lucens (Waga, 1857) bélflóráján. (Studies in earthworm bacteriology I. The properties of bacteria isolated from the gut content of Eisenia lucens.)

129-141

Sterbetz István: Görögországi megfigyelések gerinces állatfajok ökológiájáról. (Beobachtungen aus Griechenland über die Ökologie von Wirbeltierarten.) ..... 143-151

Szabó István: Hazai madár- és emlősfészkek faunisztikai vizsgálata. (Examination of the fauna in the nests of mammals and birds of Hungary.) $153-158$

Széky Pál: Az etológia szerepe a zoológiai kutatásokban. (The role of ethology in zoological research.) $159-164$

Szontagh Pál: A Lymantria dispar L. gradációs viszonyai Magyarországon 1962-1975 között. (Die Gradationsverhältnisse von Lymantria dispar L. in Ungarn zwischen 1962 1975.) $165-172$

Barta Zoltán: A "Tiszai akció" 1974. őszi madártani eredményeinek ismertetése. [Report about the ornithological results of the „Tisza action” in the autumn of 1974.] .. 173-176

Keve András: Matvejev, S. D.: Survey of the Balcan Peninsula Bird Fauna. Conspectus Avifauna Balcanicae I. Woodpeckers and Perching Birds. Piciformes and Passeriformes. (Monographs of the Serbian Academy of Sciences and Art, Section for Natural and Mathematical Sciences, Nr. 46. 1976, 365 oldal, 30 elterjedési térképvázlattal, 47 biotópfelvétellel és 10 rajzzal). [Book review.] 177

Vargha Béla: De Wailly, Ph.: L'amateur des oiseaux de cage et de voliére. (J. B. Bailliére Editions, Paris, 1972, 375 oldal). [Book review.] $177-178$

Vargha Béla: Harrison, C.: Jungvögel, Eier und Nester aller Vögel Europas, Nordafricas und des Mittleren Ostens. (Paul Parey Verlag, Hamburg und Berlin, 1975, 371 oldal, 930 ábrával, melyből 827 színes). [Book review.] 178

Anghi Csaba: Heptner, V. G. \& Naumov, N. P. \& Jürgenson, P. B. \& Sludski, A. A. \& Cirkova, A. F. \& Bannikov, A. G.: Die Säugetiere der Sowjetunion. II. Band. Seekühe und Raubtiere. (VEB Gustav Fischer Verl., Jena, 1974, 1006 oldal, 181 ábrával és 63 táblával). [Book review.] $178-179$

Vargha Béla: Wilson, E. O.: Sociobiology - the New Synthesis. (The Belknap Press of Harvard University Press, Cambridge, Massachusetts and London, 1975, 697 oldal). [Book review.] 179-180

Vargha Béla: Immelmann, K.: Wörterbuch der Verhaltenvorschung. (Kindler Taschenbücher. Kindler Verlag GmbH, München, 1975, 136 oldal). [Book review.] 180

Papp László: Szakosztályunk ülései. [Sessions of our section.] $181-188$

Hibaigazítás. [Correction.] $188-189$ 


\section{5. kötet - 1978}

1-4. füzet:

Lukács Dezső: Tóth Sándor születésének 150. évfordulójára. (Zum 150. Jahrestag der Geburt von Sándor Tóth.) 3-6

Kádár Zoltán \& Nagy István Zoltán: 100 éve született Nopcsa Ferenc. (The 100th anniversary of Ferenc Nopcsa's birth.) ................................................................. 7-12

Lukács Dezső \& Veress Elemér, ifj.: Emlékezés Veress Elemérre születésének 100 éves évfordulója alkalmából. (Erinnerung an Elemér Veress anlässlich des 100. Jahrestages seiner Geburt) 13-19

Keve András: Frantisek J. Turček (1915-1977). [In memoriam.] 21-23

Bakonyi Gábor: Német csótány (Blattella germanica L.) populációk létszámbecslése jelölés-visszafogás módszerrel. (Examination of the applicability of the mark-recapture method in German cockroaches (Blattella germanica L.).) 25-30

Balázs Klára, Kozár Ferenc \& Mihályi Krisztina: Nagyüzemi és házikerti almások molylepke (Microlepidoptera) és pajzstetü (Homoptera: Coccoidea) népességének összehasonlítása. (Almás ökoszisztéma kutatások 2.). (Comparison of moth- (Microlepidoptera) and scale-insect (Homoptera:Coccoidea) populations of large-scale and domestic appleorchards (Apple-orchard ecosystem researches, no. 2.).) ................................ 31-37

Boros István: Megdőlt-e a darwinizmus? [Has Darwinism fallen down?] ................... 39-46

Endes Mihály: Vízimadár-világ az erdőspusztán. (Wasservogelwelt der „Waldpussta".) 47-50

Fábián Gyula: Hazai nagyvadjaink immobilizációja neuroleptanalgeziás állapotot előidéző szerek keverékével. (Immobilization of Hungarian big game by means of a mixture of agents inducing a neuroleptanalgesic condition.) $51-61$

Fodor Tamás: Az őzállomány mennyiségének és minőségének elemző vizsgálata. (Analysierende Untersuchung der Quantität und Qualität des Rehbestandes.) ..... 63-68

Karner István: A mezeinyúl (Lepus europaeus Pall.) mint a peszticidek környezetszennyezésének indikátora. (The brown hare as an indicator of pollution with pesticides.) 69-81

Keve András: Vizsgálatok a magyarországi karvalyokon. (Über den Sperber in Ungarn.) 83-98

Mészáros Zoltán: Nagyüzemi és házikerti almások lepkefaunájának összehasonlítása. (Almás ökoszisztéma kutatások 3.) (Vergleich der Schmetterlingfauna der Apfelkulturen von Großwirtschaften und Kleingärten. (Forschungen vom Ökosystem der Apfelanlagen, 3.).) ........................................................................... 99-102

Podani János: Néhány klasszifikációs és ordinációs eljárás alkalmazása a malakofaunisztikai és cönológiai adatok feldolgozásában I. (Application of some classification and ordination procedures in the analysis of malacofaunistical and cenological data I.) 103-113 
Ponyi Jenő \& Bankós László: Különböző növényvédőszerek hatása a Gammarus roeseli Gervais nevü Amphipoda fajra. (Die Wirkung von verschiedenen Pflanzenschutzmitteln auf die Amphipodenart Gammarus roeseli Gervais.) $115-126$

Sterbetz István: Magyarország túzokállománya (Otis t. tarda) 1977-ben. (Der Großtrappenbestand Ungarns im Jahre 1977.) ................................................ 127-136

Szilágyi Attila: Vizsgálatok a várpalotai iparvidék levegőszennyezett területén. (Untersuchungen in dem durch die Luftverunreinigung geschädigten Gebiet des Industriebezirkes von Várpalota.) $137-146$

Szontagh Pál: Biológiai védekezés madár-megtelepítéssel nyár állományokban. (Biologische Bekämpfung durch Ansiedlung von Vögeln in einem Pappelbestand.) $147-152$

Uherkovich Ákos: Dél- és Nyugat-Dunántúl nagylepkéinek néhány állatföldrajzi kérdése. (Einige zoogeographische Fragen der Großschmetterlinge Süd und Westtransdanubiens.) $153-162$

Keve András: Bíró Lajos madártani gyüjtőútjairól. (Angaben zur ornithologischen Sammeltätigkeit von L. Bíró.) 163-164

Endes Mihály: A vörös ásólúd (Casarca ferruginea [Pall.]) Magyarországon. (Die Rostgans (Casarca ferruginea [Pall.]) in Ungarn.) 165

Szvezsényi László: Adatok néhány fészkelő madárfaj mennyiségi viszonyaihoz az akolháti madárerdőben. (Angaben zu den quantitativen Verhältnissen einige Nestvogelarten im „Vogelwald" von Akolhát.) $167-170$

Andrássy István: Kaestner, A.: Lehrbuch der Speziellen Zoologie. Band I.: Wirbellose. 3. Teil: Insecta, B: Spezieller Teil. (VEB Gustav Fischer Verl., Jena, 1973, 907 oldal, 405 ábrával). [Book review.]

Dely Olivér György: Geiler, H.: Allgemeine Zoologie. Taschenbuch der Zoologie. Band 1. (Negyedik, erősen módosított kiadás. VEB Gustav Fischer Verl., Jena, 1974, 471 oldal és 390 ábra). [Book review.]

Vargha Béla: Immelmann, K.: Einführung in die Verhaltensforschung. (Parey Studientexte, Nr. 13. Parey Verl., Berlin-Hamburg, 1976, 221 oldal, 89 ábrával). [Book review.] $172-173$

Dely Olivér György: Rudolf Piechocki: Makroskopische Präparationstechnik. Leitfaden für das Sammeln, Präparieren und Konzervieren. Teil II.: Wirbellosen. (VEB Gustav Fischer Verl., Jena, 1975, 349 oldal, 2 táblázat és 156 ábra). [Book review.] .... 173-174

Andrássy István: Hentschel, E. \& Wagner, G.: Tiernamen und zoologische Fachwörter, unter Berücksichtigung allgemeinbiologischer, anatomischer und physiologischer Termini. (VEB Gustav Fischer Verl., Jena, 1976, 507 oldal). [Book review.]

Vargha Béla: Heymer, A.: Ethologisches Wörterbuch - Ethological dictionary Vocabulaire ethologique. (Paul Parey Verl., Berlin-hamburg, 1977, 238 oldal, 138 ábrával). [Book review.] 174-175

Dely Olivér György: Mocek, R.: Wilhelm Roux - Hans Driesch. Zur Geschichte der Entwicklungsphysiologie der Tiere. (Biographien bedeutender Biologen. Band 1. VEB Gustav Fischer Verl., Jena, 1974, 229 oldal és 2 fénykép). [Book review.] 
Dely Olivér György: Werner, F. C.: Die Kopf- und Körperhaltung und das Gleichgewichtsorgan der Wibeltiere. (VEB Gustav Fischer Verlag, Jena, 1975, 86 oldal és 56 ábra). [Book review.] 176

Andrássy István: Hartwixh, G.: Schlauchwürmer, Nemathelminthes. Rund- oder Fadenwürmer, Nematoda. Parasitische Rundwürmer von Wirbeltieren. I.: Rhabditida und Ascaridida. (In: Die Tierwelt Deutschlands, 62. füzet. VEB Gustav Fischer Verl., Jena, 1975, 97 ábrával, 256 oldal). [Book review.] $176-177$

Keve András: Glutz v. Blotzheim, U. N.: Handbuch der Vögel Mitteleuropas. Bd. 7. (Akademische Verlagsgesellschaft, Wiesbaden, 1977, 895 oldal, 3 színes tábla, 138 ábra). [Book review.]

Keve András: Klafs, G. \& Stübs, J.: Die Vogelwelt Mecklenburgs. (Gustav Fischer Verl., Jena, 1977, 358 oldal, 17 diagram, 41 elterjedési térkép, 32 fotótábla, 1 színes áttekintö térkép). [Book review.] $177-178$

Keve András: Fischer, Wolfgang: Stein-, Kaffern- und Keilschwanzadler. (Die Neue Brehm-Bücherei, Nr. 500. A. Ziemsen Verlag, Wittenberg-Lutherstadt, 1976, 220 oldal, 97 ábra, 1 színes tábla). [Book review.] 178

Papp László: Szakosztályunk ülései. [Sessions of our section.] $179-186$

\section{6. kötet - 1979}

1-4. füzet:

Kaszab Zoltán: Megemlékezés Dr. Soós Lajos születésének 100. évfordulójára. [In memoriam Dr. Lajos Soós, on the occasion of the $100^{\text {th }}$ anniversary of his birth.] .... 3-9

Lukács Dezső: Gelei József, a tanítvány és munkatárs szemével. [József Gelei, through the eyes of a student and colleague.] $11-16$

Szabó István: Emlékezés Charles Rothschildra születésének 100 éves évfordulója alkalmából. (In remembrance of Charles Rothschild on the occasion of the $100^{\text {th }}$ anniversary of his birth.) $17-20$

Ábrahám Ambrus: A receptorok helye és szerkezete a sündisznó (Erinaceus europaeus) orrabörében fény- és elektronmikroszkóp alatt. (The place and structure of the receptors in the nasal skin of the hedgehog (Erinaceus europaeus) under the light- and electron microscope.) $21-43$

Ambrus Béla: Fenyőtoboz- és magkártevő gubacslegyek (Diptera: Cecidomyidae). (Gallmücken (Diptera - Cecidomyiidae), als Kieferzapfen- und Samenschädlinge.) $45-55$

Bierbauer József - Fehér Zsuzsa: A cerebrális dúc homogenizátumának hatása az éti csiga (Helix pomatia) gametogenezisére. (Die wirkung des Homogenisats des Zerebralganglions auf die Gametogenese der Weinbergschnecke (Helix pomatia) $57-63$

Faragó Sándor: A környezeti tényezők hatása a Hanság túzokállományára. (Wirkung der Umweltsfaktoren auf den Großtrappenbestand der Hanság.) $65-73$ 
Havasi András: Adatok az erdőben és a mezőn élő őzek produkcióbiológiájához. (Data on the production biology of the roe deer living in the forest and in the fields.)

Jermy Tibor: Az agroökoszisztéma-kutatás néhány elvi kérdéséről. (Some questions of research on agro-ecosystems.)

Kalabér László: Adatok a vízirigó (Cinclus cinclus L., 1748) biológiájához. (Beiträge zur Biologie der Wasseramsel (Cinclus cinclus L., 1748).) 93-101

Keve András: Kiegészítések a madarak urbanizációjáról szóló tanulmányomhoz. (Ergänzungen zu meiner Studie über die Urbanisation der Vögel.) $103-108$

Lövei Gábor: Biometriai módszerek a madárvonulás kutatásában. (Biometrical methods in the research of bird migration.) 109-115

Pintér István: A Hévízi-tó és a környező berek csigafaunája. (Die Schneckenfauna des Thermalteiches und der Sumpfwiese von Héviz (Ungarn).) $117-130$

Rácz Vera: Heteropterológiai vizsgálatok kukoricásban. (Heteropterologische Untersuchungen am Maisfeld.) $131-134$

Sasvári Lajos: A városi életkörülményekhez való alkalmazkodás néhány madáretológiai vonatkozása. (Some ethological respects of the adaptation of birds to the urban conditions of life.) $135-140$

Sebestyén Olga: Bioszféra - ökoszisztéma - környezet: a három ökológiai fogalom limnológiai értelmezése. [Biosphere - ecosystem - environment: the limnological meanings of these three concepts of ecology.] $141-152$

Sterbetz István: A monokultúrás kukoricatermesztés szerepe a vízimadárvonulás táplálékbázisában. (The role of the maize monocultures in the food basis of the migration of water fowl.) $153-159$

Szentendrey Géza, Lövei Gábor \& Kállay György: Az "Actio Hungarica" madárgyürüző tábor mérési módszerei. (Measuring methods of the camp "Actio Hungarica" for ringing birds.) $161-166$

Szontagh Pál: A Nycteola asiatica Krul. (Lepidoptera: Noctuidae) életmódja és károsítása nyárállományokban. (Die Lebensprozesse von Nycteola asiatica Krul. (Lepidoptera: Noctuidae) und ihre Schädigungen in den Pappelbeständen.) $167-171$

Tátrai István: A táplálék hatása a fehér amúr (Ctenopharyngodon idella Val.) ivadékának anyagcseréjére. (The effect of food on the rate of metabolism in grass carp (Ctenopharyngodon idella Val.).) $173-178$

Vargha Béla: Etológiai adatok a rizspintyek (Padda oryzivora; Estrildidae) biológiájához. (Ethologische Angaben zur Biologie der Reisfinken (Padda oryzivora; Estrildidae).) 179-192

P. Zánkai Nóra: Az Eudiaptomus gracilis (G. O. Sars) (Copepoda) egyedfejlődése a Balatonban. (The duration of development of Eudiaptomus gracilis (G. O. Sars) (Copepoda) in Lake Balaton.) 193-208

Zimmermann István: Az állatszállításoknál történő elhullások elemzése meteorobiológiai és biofizikai módszerek alkalmazásával. (Analyse der Verluste bei den Viehtransporten durch Anwendung meteorobiologischer und biophysikalischer Methoden.) 209-211 
Andrássy István: Újabb harminc Nematoda-faj a magyar faunában. (Thirty Nematode species new to the fauna of Hungary.) 213-216

Kasza László: Álterhesség a Veszprémi Állatkert egyik nőstény csimpánzánál. [Pseudopregnancy in one of the female chimpanzees at the Veszprém Zoo.] .... 217-218

Lövei Gábor: Vizsgálatok a barátposzáta (Sylvia atricapilla L.) és a csilpcsalp füzike (Phylloscopus collybita Vieill.) tavaszi vonuló populációin. [Studies on the spring migrant populations of the Eurasian Blackcap (Sylvia atricapilla L.) and the Common Chiffchaff (Phylloscopus collybita Vieill.).] $219-220$

Andrássy István: Arno Hermann Müller: Lehrbuch der Paläzoologie. II. Invertebraten. 3. Arthropoda 2. Hemichordata. (VEB Gustav Fischer Verl., Jena, 1978, 748 oldal, 825 ábrával). [Book review.]

Andrássy István: Ragnar K. Kinzelbach: Strepsiptera. Die Tierwelt Deutschlands, 65. rész. (VEB Gustav Fischer Verl., Jena, 1978, 166 oldal, 53 ábrával). [Book review.] 221-222

Loksa Imre: Martens, J.: Weberknechte, Opiliones. Die Tierwelt Deutschlands, 64. rész. (VEB Gustav Fischer Verl., 464 oldal, 815 ábrával). [Book review.]

Dely Olivér György: Dathe, H.: Wirbeltiere I. Taschenbuch der Zoologie. Band 4. (VEB Gustav Fischer Verl., Jena, 1974, 244 oldal és 234 ábra). [Book review.]

Dely Olivér György: J. Robb: The Tuatara. (Meadowfield Press Ltd., Shildon Co. Durham, Patterns of Progress, Zoology Series, 1977, 64 oldal, 22 ábrával). [Book review.] 222-223

Lövei Gábor: Brown, Leslie: British Birds of Prey. (The New Naturalist Series. William Collins Sons and Co. Ltd., London, 1976, 400 oldal, 16 tábla, 25 táblázat, 11 ábra, 34 térkép). [Book review.] 223

Lövei Gábor: Perrins, C. \& Cameron, A.: Bird Life. An introduction to the world of birds. (Elsevier-Phaidon, Oxford, 1976, 160 oldal). [Book review.] 223-224

Keve András: Bogdan Stugren: Grundlagen der allgemeinen Ökologie. (Harmadik, bővített és átdolgozott kiadás. VEB G. Fischer Verl., Jena, 312 oldal, 151 képpel és 8 táblázattal). [Book review.]

Andrássy István: Otto Pflugfelder: Wirtstierreaktionen auf Zooparasiten. (VEB Gustav Fischer Verl., Jena, 1977, 378 oldal, 117 ábrával). [Book review.] 224

Dely Olivér György: Tembrock, G.: Verhaltensbiologie unter besonderer Berücksichtigung der Physiologie des Verhaltens. (Wörterbücher der Biologie, VEB Gustav Fischer Verl., Jena, 1978, 224 oldal és 75 ábra). [Book review.] 225

Dely Olivér György: Wunderlich, K.: Rudolf Leuckart, Weg und Werk. (Biographien beteutender Biologen. Band 2. VEB Gustav Fischer Verl., Jena, 1978, 152 oldal és 12 ábra). [Book review.] 225-226

Bakonyi Gábor: Szakosztályunk ülései. [Sessions of our section.] $227-232$ 


\section{7. kötet - 1980}

1-4. füzet:

Fábián Gyula: Visszapillantás az Állattani Szakosztály történetére és munkásságára a szakosztály 700. ülésén. [Retrospect to the history and activity of the Zoological Section on its $700^{\text {th }}$ session.] 3-6

Keve András: Megemlékezés Vezényi Árpádról és dél-amerikai gyüjtőútjáról. (Erinnerung an A. Vezényi und an seine Sammelreise in Südamerika.) $7-12$

Bakkay László, Bán István \& Fodor Tamás: A hazai őzállomány értékmérőinek számítógépes elemzése. (Analyse der Wertmesser des einheimischen Rehbestandes mit dem Komputer.) $13-32$

Botta István, Keresztessy Katalin \& Neményi István: Faunisztikai és akvarisztikai tapasztalatok az édesvizi akvárium üzembehelyezésével kapcsolatban. (Faunistische und aquaristische Erfahrungen in der Verbindung der Inbetriebsetzung des Süßwasseraquariums.) $33-42$

Csikváry László: Néhány kis testü kérődző faj tenyésztési eredménye a Fővárosi Állat- és Növénykertben. (Züchtungserfolge mit einigen kleinwüchsigen Wiederkäuerrassen im Budapester Zoologischen Garten.) 43-47

Gulyás Pál: A Velencei-tó vízminőségi tájainak jellemzése planktonrákokkal. (Charakterisierung der Wasserqualitätsregionen des Velencer Sees mit Planktonkrebsen.) $49-57$

Horváth László \& Péteri András: A tógazdasági pontyok petesejtjeinek és petefészkének fejlődése Magyarországon. (Entwicklung der Eizellen und des Ovariums bei den Karpfen der Teichwirtschaften in Ungarn.) 59-64

Kádár Zoltán: Linné állatrendszertani nézeteinek fejlődéséről. [On the development of Linné's zoosystematic views.] 65-69

Kovács Gyula: Újabb adatok és kritikai megjegyzések Sopron és környéke csigafaunájához. [New data and critical remarks on the mollusc fauna of Sopron and its environment.] $71-75$

Mödlinger Pál: A mesterséges vadmadárkeltés és fiókanevelés eredményei a Fővárosi Állat- és Növénykertben. [Results of the man-made wild bird incubation and young bird rearing in the Budapest Zoo.] $77-83$

Podani János: Néhány klasszifikációs és ordinációs eljárás alkalmazása a malakofaunisztikai és cönológiai adatok feldolgozásában II. (Application of some classification and ordination procedure in the analysis of malacofaunistical and cenological data, II.) $85-98$

Rékási József: Adatok a balkáni gerle (Streptopelia decaocto) táplálkozásbiológiájához. [Data to the feeding biology of the Eurasian Collared Dove (Streptopelia decaocto).] 99-108

Sterbetz István: Madarak energiafelvétele égetett búzatarlókon. [The energy uptake of the birds on burned wheat-cuts.] 109-112 
Szalay László: Adatok néhány aknázó moly-faj átteleléséhez. [Data to the overwintering of some leaf miner species.]

Andrássy István: Egy új Nematoda-faj a Sashegyröl. (Scutylenchus apricus sp. n., a new Nematode species from Budapest, Hungary.)

119-121

Endes Mihály: A bütykös ásólúd (Tadorna tadorna L.) Magyarországon. [The Common Shelduck (Tadorna tadorna L.) in Hungary.]

123-124

Rékási József: Madártani megfigyelések a madarasi nádasban fészkelö gém fajokon. [Ornitological observations on the heron species nesting in the common reed at Madaras.] 125

Andrássy István: Hennig, W.: Wirbellose I. (Ausgenommen Gliedertiere). Vierte, neubearbeitete Auflage. (VEB Gustav Fischer Verlag, Jena, 1979, 392 oldal, 280 ábrával). [Book review.] 127

Andrássy István: Schliephake, G. \& Klimt, K.: Thysanoptera - Fransenflügler. In: Die Tierwelt Deutschlands, 66. Teil. (VEB Gustav Fischer Verlag, Jena, 1979, 477 oldal, 528 ábrával és 34 táblázattal. [Book review.]

127-128

Lövei Gábor: Harrison, C. J. O.: Bird families of the world. (Elsevier-Phaidon, Oxford, 1978, 264 oldal). [Book review.] 128

Széky Pál: Peters, G.: Vergleichende Untersuchung zu Lautgebung einiger Feliden (Mammalia, Felidae). [Book review.] 128-129

Széky Pál: Remmert, H.: Ökologie (Ein Lehrbuch). (Springer Verlag, Berlin-HeidelbergNew York, 1978). [Book review.] 129-130

Keve András: Udvardy, M. D. F.: World biogeographical provinces. (IUCNNR Occasional Paper No. 18., MAB Project No. 8., 1978). [Book review.] 130

Udvardy Miklós: Kádár, Zoltán: Survivals of Greek zoological illuminations in Byzantine manuscripts. (Akadémiai Kiadó, Bp., 1978, 138 oldal, 232 fekete-fehér és 10 színes tábla). [Book review.] $130-131$

Vargha Béla: Sebeok, Th. A.: How animals communicate? (Indiana University Press, Bloomington and London, 1977, XXI + 1128 oldal, 64 táblázat, 299 ábra). [Book review.] 132

Vargha Béla: Hilman, J. P.: Optical signals. Animal communication and light. (Indiana University Press, Bloomington and London, 1977, XIX + 362 oldal, 71 ábra, 28 táblázat). [Book review.] $132-133$

Kádár Zoltán: Soó Rezső: Bibliographia synoecologica scientifica hungarica 1900-1972. (Akadémiai Kiadó, Bp., 1978, 500 oldal). [Book review.] 133

Bakonyi Gábor: Szakosztályunk ülései. [Sessions of our section.] $135-140$ 


\section{8. kötet - 1981}

1-4. füzet:

Keve András: Megemlékezés Madarász Gyuláról (1858-1931). (Dr. Gyula Madarász.) $3-12$

Lukács Dezső: Abonyi Sándor születésének 100 éves évfordulójára. (Zum 100 jährigen Geburtstag von Sándor Abonyi.) $13-18$

Ábrahám Ambrus: Fény- és elektronmikroszkópos vizsgálatok az éticsiga gastrointestinális idegrendszerében. (Licht- und Elektronenmikroskopuntersuchungen am gastrointestinalen Nervensystem der Weinbergschnecke.) $19-25$

Bozai József: Faunisztikai és populációdinamikai vizsgálatok fitofág és ragadozó atkákon nagyüzemi és házikerti gyümölcsökben. (Ökoszisztéma kutatások.) (Faunistische und populationsdynamische Untersuchungen an phytophagen und Raubmilben der Obstbaubetriebe und der Kleingärten (Ökosystema-Forschungen).) 27-31

Csikváry László: Nagymacska-fajok tenyésztése a Fővárosi Állat- és Növénykertben. [Rearing of big cat species in the Budapest Zoo.] 33-38

Faragó Sándor: Egy nyugat-magyarországi település - Újkér - fecskeállományának vizsgálata. 1. Molnárfecske (Delichon urbica L.). (Untersuchung des Schwalbenbestandes von einer Westungarischen Siedlung (Újkér). 1. Mehlschwalbe (Delichon urbica [L.]).)

Fehér György, Gráf Zoltán \& Sótonyi Péter: Néhány érdekesség a zsiráf csontos vázáról. (Einige Besonderheiten über das Knochengerüst der Giraffe.) 49-60

Forró László: Két faunára új Cyclops faj (Crustacea, Copepoda) a Hortobágyi Nemzeti Parkból. (Two cyclopoid species new to the Hungarian fauna from Hortobágy National Park.) $61-65$

Harka Ákos: A csuka (Esox lucius L.) növekedése a Tisza tiszafüredi szakaszán. (Das Wachstum des Hechtes (Esox lucius L.) im Theissabschnitt bei Tiszafüred.) $67-75$

Jakab Béla: Gólyaállományunk újabb adatai és problémái az 1979. évi országos felmérés alapján. (Neuere Daten und Probleme unseres Storchbestandes auf Grund der Landesvermessung im Jahre 1979.) $77-83$

Kádár Zoltán: Lamarck és a magyar élettudomány. (Lamarck et la biologie hongroise.) $85-88$

Kalotás Zsolt \& Nikodémusz Etelka: Szelektív varjúirtás lehetősége a 3-klór-4-metilanilinhidroklorid anyaggal. 1. Etetési és szabadföldi vizsgálatok a vetési varjún (Corvus frugilegus L.). (A selective rook control possibility using 3-chloro-4-methylanilinehydrochloride : 1. Feeding test and field experiments with the rook (Corvus frugilegus L.).) 89-96

Meszleny András, Szalay-Marzsó László \& Jenser Gábor: Levéltetvek tömeges gyűjtése szívócsapdákkal 1978-ban. (Alma ökoszisztéma kutatások, 13). (Massenfang von Blattläusen mittels Saugfallen im Jahre 1978 (Untersuchungen des Apfelökosystems).) 
Nikodémusz Etelka, Kalotás Zsolt \& Imre Rózsa: Szelektív varjúirtás lehetősége a 3-klór4-metilanilin-hidroklorid anyaggal. 2. Az akut toxicitás vizsgálata a vetési varjún (Corvus frugilegus L.) a dolmányos varjún (Corvus corone cornix L.), valamint a fácánon (Phasianus colchicus L.) és az egerészölyvön (Buteo buteo L.). (A selective rook control possibility using 3-chloro-4-methylaniline-hydrochloride: 2. Testing acute toxicity to the rook (Corvus frugilegus L.), the hooded crow (Corvus corone cornix L.), as well as the pheasant (Phasianus colchicus L.) and the buzzard (Buteo buteo L.).) 105-109

P. Zánkai Nóra: Daphnia-fajok táplálkozása a Balatonban. (Die Nahrungsaufnahme von Daphnia-Arten im Balaton.) $111-121$

Andrássy István: Újabb megfigyelés fonálférgekben élősködő fonálférgekről. (A new observation on Nematodes parasitic in Nematodes.) $123-126$

Keve András: Madártani jegyzetek. 1. A madarak terjeszkedése Budapest belterületén. [Ornitological notes 1. The spreading of birds in the inside area of Budapest.] 127

Keve András: Madártani jegyzetek. 2. A billegető cankó első Duna-menti fészkelése. [Ornitological notes 2. The first nesting of the common sandpiper at the Danube.] .. 128

Ponyi Jenő, Aranyiné Rehák Margit \& Gerencsér László: Három balatoni Unio-faj ( $U$. crassus Retzius, $U$. tumidus Retzius, $U$. pictorum Linné) héjméreteinek és testsúlyának viszonya. [Relation of the shellsize and bodyweight in three Balaton Lake-dwelling Unio species (U. crassus Retzius, U. tumidus Retzius, U. pictorum Linnaeus).] 129-130

Fazekas Imre: Higgins, G. L.: The Classification of European Butterflies. (Collins St. James'S. Place, London, 1975. 320 oldalon 402 ábrával és 1 térképpel). [Book review.]

131

Fazekas Imre: Jerzy Heintze: Motyle polski atlas. (Wydawnictwa Szkolne i Pedagogiczne, Warszawa, 1975. 302 oldal, 300 ábrával). [Book review.] $131-132$

Keve András: Glutz v. Blotzheim, N. \& Bauer, K. M.: Handbuch der Vögel Mitteleuropas. 9. Columbiformes-Piciformes. (Akademie Verlag, Wiesbaden, 1980. 1148 oldal, 212 ábrával (közte számos térkép) és 69 táblázattal). [Book review.] 132

Keve András: Engler, Helmut: Die Teichralle (Gallinula chloropus). (Neue BrehmBücherei, No. 535, A. Ziemsen Verlag, Wittenberg-Lutherstadt, 1980. 228 oldal, 103 ábrával és fényképpel, 2 színes táblával). [Book review.] 132

Fehér György: Julian J. Baumel: Nomina Anatomica Avium. (Academic Press, LondonNew York-Toronto-Sydney-San Francisco. 637 oldal). [Book review.] ............ 132-133

Bakonyi Gábor: Szakosztályunk ülései. [Sessions of our section.] .......................... 135-140 


\section{9. kötet - 1982}

1-4. füzet:

DUDICH ENDRE EMLÉKÜLÉS ELŐADÁSAI

Berczik Árpád: A Duna zoológiai vizsgálatának néhány tanulsága. (Über einige zoologische Resultate der Donauforschung in Ungarn.) ......................................... 1-5

Kaszab Zoltán: A faunisztikai és rendszertani kutatások múltja, jelene és jövője Magyarországon. (Vergangenheit, Gegenwart und Zukunft der faunistisch-systematischen Forschungen in Ungarn.) $7-12$

Zicsi András: Új állatökológiai kutatások lehetősége az aggteleki Baradla-barlang biológiai laboratóriumában. (Über neue zooökologische Forschungsmöglichkeiten im biologischen Laboratorium der Baradla-Höhle bei Aggtelek.) 13-27

Lukács Dezső: Emlékezés Zilahi-Sebess Gézára. [In memoriam Géza Zilahi-Sebes.] 29-32

Ábrahám Ambrus: Fény- és elektronmikroszkópos vizsgálatok a mocsári teknős (Emys orbicularis) szívfalazatán. (Licht- und elektronenmikroskopische Untersuchungen an der Herzwand der Sumpfschildkröte (Emys orbicularis).) $33-42$

Demeter András \& Topál György: Kittenberger Kálmán kelet-afrikai expedíciói és az általa gyüjtött emlősök. (Kálmán Kittenberger's expeditions to East Africa and his collection of mammals.) 43-59

Domokos Tamás \& Kovács Gyula: A balatoni Fekete-part és környékének malakofaunája. (Die Malakofauna des Fekete-part (Schwarzen Ufers) am Balaton und in seiner Umgebung.) $61-68$

Egri Borisz: Az állatok idegrendszeréről alkotott elképzelések a kor biológiai felfedezéseinek tükrében, Apáczai Csere János és Johann Gottfried Herder műveiben. (Die über das Nervensystem der Tiere gebildeten Vorstellungen im Spiegel der biologischen Entdeckungen des Zeitalters, in den Werken von János Apáczai Csere und Johann Gottfried Herder.) 69-74

Faragó Sándor: A Hanság környéki túzokállomány, 5 éves magyar-osztrák szinkronfelvételek alapján. (Der Grosstrappenbestand in der Umgebung der Hanság (Wasen) auf Grund der 5 jährige Ungarisch-Österreichischen synchronen Bestandsaufnahmen.) ....... 75-84

Fazekas Imre: A Kelet-Mecseki Tájvédelmi Körzet lepidopterológiai kutatásának eddigi eredményei. (Die bisherigen Ergebnisse der lepidopterologischen Erforschung des Landschaftsschutzgebietes im Österlichen Mecsekgebirge.) $85-90$

Fodor András \& Deák Péter: A Caenorhabditis elegans (Maupas, 1900) mint genetikai modell. (Caenorhabditis elegans (Maupas, 1900), als genetisches Modell.) ........ 91-97

Halmágyi Levente \& Szalay-Marzsó László: Helikopteres kísérletek erdővédelmi és zoológiai eredményei. (Ergebnisse der Versuche mit Helikopter im Dienste des Waldschutzes und der Zoologie.) 99-105

Jenser Gábor \& Erdélyi Gábor: A Xiphinema vuittenezi Luc, Lima, Weischer \& Flegg, 1964 (Nematoda) táplálékfelvételének vizsgálata izotópokkal jelzett növényekkel. (Die Untersuchung der Nahrungsaufnahme von Xiphinema vuittenezi Luc, Lima, Weischer \& Flegg, 1964 mit isotopindizierten Pflanzen.) 107-109 
Kalotás Zsolt: Adatok az egerészölyv (Buteo buteo) táplálkozásához. (Daten zur Ernährung des Mäusebussards (Buteo buteo).)

Keve András: A Balaton szárcsaállományának összefüggése a rendelkezésre álló táplálékkal. (Korrelation zwischen der Nahrung und dem Bestand der Blässralle (Fulica atra) am Balaton.) $119-121$

Sterbetz István: Magyarországi adatok az erdei szalonka (Scolopax rusticola L., 1758) nászrepülésének fényviszonyairól. (Angaben über die Lichtverhältnisse des Balzfluges der Waldschnepfe (Scolopax rusticola L., 1758) in Ungarn.) $123-126$

Sterbetz István: Repatriációs eredmények a dévaványai Túzokkísérleti Állomáson. (Results of repatriation at the Station for Experiments with Great Bustards at Dévaványa.) $127-131$

Várnagy László - Fáncsi Tibor - Imre Rózsa - Bartalits Lilian: Teratológiai modellvizsgálat: A Parathion 20 WP növényvédőszer hatása fácán és fürj magzatokra. (Teratologische Modelluntersuchung: Die Wirkung des Pflanzenschutzmittels Parathion $20 \mathrm{WP}$ auf Phasan- und Wachtelembryonen.) $133-138$

Andrássy István: Újabb huszonöt Nematoda faj a magyar faunában. (Further twenty-five Nematode species new to the fauna of Hungary.) 139-146

Endes Mihály: A fenyőrigó (Turdus pilaris) magyarországi fészkeléseiről. (Über das Nisten der Wacholderdrossel (Turdus pilaris) in Ungarn.) 147-148

Keve András: Scherzenlechner Sebestyén mexikói madárgyüjtéséről. (Über die Sammeltätigkeit von Sebastian Scherzenlechner in Mexiko.) 149-151

Papp Jenő: R. Edwards: Social wasps. Their biology and control. (The Rentokil Library, Felcourt, East Grinstead, West Sussex, 1980. 398 oldal, 200 fekete-fehér és 8 színes fényképpel). [Book review.]

Stohl Gábor: Böhme, W. (ed.): Handbuch der Reptilien und Amphibien Europas. Band 1. Echsen (Sauria) I. (Akademische Verlagsgesellschaft, Wiesbaden, 1981. 520 oldal, 91 ábrával). [Book review.] $153-154$

Keve András: Kahl, M. Ph.: Welt der Störche. (Schüz előszavával és kiegészítéseivel. P. Parey Verlag, Hamburg-Berlin, 1981. 96 oldal, 70 ábrával). [Book review.] 154

Nagy Barnabás: Balás Géza és Sáringer Gyula: Kertészeti kártevők. (Akadémiai Kiadó, Budapest, 1982. 1069 oldal). [Book review.] 154-155

Andrássy István: A. H. Müller: Lehrbuch der Paläozoologie. II. kötet. 1. rész: ProtozoaMollusca, 2. rész: Mollusca-Arthropoda, 3. rész: Arthropoda-Hemichordata. (VEB Gustav Fischer Verlag, Jena. 1. rész: 628 oldal, 722 ábra. 1980; 2. rész: 550 oldal, 692 ábra, 1981; 3.rész: 748 oldal, 852 ábra, 1978). [Book review.] 155

Demeter András: Szakosztályunk ülései. [Sessions of our section.] $157-163$ 


\section{0. kötet - 1983}

1-4. füzet:

Lukács Dezső: Raisits Emil (1882-1934) születésének 100. évfordulójára. (Zum 100. Geburtsjahr von Emil Raisits (1882-1934).) ....

V. Balogh Katalin \& Salánki János: A Crustacea-plankton nehézfém-koncentrációja a Balatonban. (The heavy metal concentration of the crustacean plankton in Lake Balaton.)

Bierbauer József \& Fazekas Sándor: A cerebrális dúc és a tentaculáris ganglion magas sókoncentrációs és híg Tris-pufferes kivonatának hatása az éticsiga gametogenezisére. (Wirkung des starke Salzkonzentration und schwachen Tris-Puffer enthaltenden Extraktes aus dem zerebralen und tentakulären Ganglion auf die Gametogenese der Weinbergschnecke.) $17-24$

Dévai György, Félszerfalvi János, Kovács Anna \& Győri Éva: Új lehetőségek az árvaszúnyogok (Diptera: Chironomidae) taxonómiai kutatásában. I. Pásztázó elektronmikroszkópos vizsgálatok. (Neue Möglichkeiten in der taxonomischen Erforschung von Zuckmücken (Diptera: Chironomidae) I. Raster-elektronenmikroskopische Untersuchungen.) 25-31

Faragó Sándor: A túzok (Otis $t$. tarda L.) fészkelésbiológiája Magyarországon. (Die Nistbiologie der Großtrappe (Otis t. tarda L.) in Ungarn.) 33-38

Fehér György \& Gráf Zoltán: Adatok a kétpúpú teve (Camelus bactrianus) emésztőkészülékének és hasüri szerveinek topográfiájához. (Angaben zur Topographie des Verdauungskanals und der intraabdominalen Organe bei dem zweihöckerigen Kamel (Camelus bactrianus).)

39-44

Kádár Zoltán: Cuvier és a magyar reformkori zoológia. (Cuvier et la zoologie hongroise á l'ère de réformes.) $45-48$

Loksa István: Adatok a magyar aknászpók (Nemesia pannonica Herman) életmódjának ismeretéhez. (Daten zur Kenntnis der Lebensweise von Nemesia pannonica Herman.) 49-52

Nagy Sándor: Ökofaunisztikai adatok a Beregi-sík nagylepkéiről. (Ökofaunistische Daten über die Großfalter der Bereger Ebene (Ungarn).) 53-61

Papp László: A zootaxonómia hatékonyságának egyes kérdései. (Certain questions of the efficiency of zootaxonomy.) 63-67

Sterbetz István: A magyarországi vadlúdvonulás alakulása az 1972 és 1982 közötti idöszakban. (The trend of the migration of wild-geese in Hungary in the period 1972 1982.) 69-72

Szabó László, Varga Zoltán \& Lakatos Gyula: A lombfogyasztó lepkehernyók szerepe a síkfőkúti cseres-tölgyes ökoszisztémában. (Die Rolle der laubfressenden im Lepidopterenlarven Zerr-Traubeneichenwild-Ökosystem.) $73-81$

Szentkiráyi Ferenc \& Török László: Neuropteroidák madarak táplálékában. (Neuropteroids in food of birds.) 
Vásárhelyi Tamás: Egy elfelejtett kártevő, az Aradus cinnamomeus Panzer (Heteroptera: Aradidae) életmódja Magyarországon. (Bionomy of a forgotten pest, the pinebark-bug (Aradus cinnamomeus Panzer) in Hungary (Heteroptera: Aradidae).) 91-97

P. Zánkai Nóra: A Cyclops vicinus Uljanin (Copepoda) ragadozásának hatása a balatoni zooplanktonra. (Die Wirkung der Raubtätigkeit von Cyclops vicinus Uljanin (Copepoda) auf das Zooplankton des Balaton.) 99-112

Andrássy István: Caenorhabditis briggsae (Dougherty \& Nigon, 1949) - A genetika egyik kísérleti állata (Nematoda: Rhabditidae). ((Caenorhabditis briggsae (Dougherty \& Nogon, 1949) - A model of genetics.) 113-116

Dely Olivér György: Mikor jelent meg a parlagi vipera (Vipera ursinii rakosiensis Méhely) leírása? (Wann ist die Beschreibung von Méhely über Vipera ursinii rakosiensis erschienen?) 117

Demeter András: A harmadik nemzetközi emlőstani kongresszus. (The third international congress of mammalogy.) 119-120

Endes Mihály: Jávorszarvas (Alces alces [L.]) megjelenése Magyarországon. (Das Erscheinen von Elchen (Alces alces [L.]) in Ungarn.)

Andrássy István: A magyar zoológusok névjegyzéke. (Register of the Hungarian zoologists.) $123-140$

Stohl Gábor: Raabe, Marie: Insect Neurohormones. (Plenum Press, New York-London, 1982. XIV + 352 oldal, 91 ábrával). [Book review.] 141

Fazekas Imre: Heath, J. \& Emmet, M. A.: The moths and butterflies of Great Britain and Ireland. Volume 9. Sphingidae-Noctuidae (Part I.). (Curwen Books, London, 1979. 278 oldalon 19 ábrával, 203 térképpel és 13 színes táblával). [Book review.] 142

Dely Olivér György: Tembrock, G.: Spezielle Verhaltensbiologie der Tiere. (VEB Gustav Fischer Verlag, Jena. Band I: Funktionskreise. Wirbellose. 1982, 528 oldal és 345 ábra; Band II: Wirbeltiere. 1983, 411 oldal és 208 ábra). [Book review.]

Vargha Béla: Inskipp, T. \& Wells, S.: International trade in wildlife. (Earthscan, London, 1979. 104 oldal, 9 ábrával, 11 fényképpel és 10 táblázattal). [Book review.] 143

Vargha Béla: Nilsson, G., Stevens, Ch. \& Gleiber, J.: Facts about furs. (Animal Welfare Institute, Washington, 1980. 258 oldal, 79 fényképpel és 54 táblázattal). [Book review.] 143-144

Andrássy István: Dely O. Gy. és Stohl G. szerkesztésében: Vertebrata Hungarica, 21. kötet. (Természettudományi Múzeum kiadványa, Budapest, 1982. 262 oldal, számos melléklettel). [Book review.] 144

Keve András: Kiss J. Botond: A Delta könyve. (Kriterion Kis Kalauz, Bukarest, 1982. 247 oldal, 50 fényképpel és 8 térképvázlattal). [Book review.] 144

Demeter András: Szakosztályunk ülései. [Sessions of our section.] $145-150$

Csutorné Bereczky Magdolna: A Protozoológiai Szakosztály előadásai. [Presentations of the Protozoological Section.] $151-152$ 


\section{1. kötet - 1984}

1-4. füzet:

Vass Anna: Emlékezés Gebhardt Antalra (1887-1972). [In memoriam Antal Gebhardt (1887-1972).] 3-5.

DR. BALOGH JÁNOS TISZTELETÉRE RENDEZETT ÜLÉS ELÖADÁSAI

Andrássy István: Gondolatok a Nematodák evolúciós rendszerezéséről. (Reflections on the evolutional systematization of the Nematodes.) $7-11$

Berczik Árpád: A Pilis Bioszféra Rezervátum kutatási programja. (The research programme of the Pilis Biosphere Reserve.) 13-16

Mahunka Sándor: A talajlakó páncélosatkák (Oribatida) áreatörténetének és evolúciójának néhány kérdése. (Some questions of the area history and evolution of soil-inhabiting beetle mites (Oribatida).) $17-22$

Bende Sándor \& Bende Sándor (ifj.): Kísérletes endotoxin-sokkos kutyák szerveinek elektronmikroszkópos vizsgálata, különös tekintettel a hasnyálmirigyre. [Electron microscopic investigation of the organs of experimentally endotoxin-shocked dogs, with special attention to the pancreas.] $23-29$

Bierbauer József \& Fazekas Sándor: A glandula albumifera híg Tris-pufferes magas sókoncentrációs kivonatának és gélfilttrációs tisztításának hatása az éticsiga (Helix pomatia) gametogenezisére. (Wirkung des schwachen Tris-Puffer und hohe Salzkonzentration enthaltenden Extraktes aus der Glandula albumifera und der Gelfiltrationsreinigung auf die Gametogenese der Weinbergschnecke.) $31-37$

Botta István, Keresztessy Katalin \& Neményi István: Halfaunisztikai és ökológiai tapasztalatok természetes vizeinkben. (Fischfaunistische und ökologische Erfahrungen in unseren natürlichen Gewässern.) $39-50$

Dévai György, Moldován Judit \& Lőrincz Gábor: Új lehetőségek az árvaszúnyogok (Diptera: Chironomidae) taxonómiai kutatásában. II. Kariológiai vizsgálatok. (Neue Möglichkeiten in der taxonomischen Erforschung von Zuckmücken (Diptera: Chironomidae) II. Karyologische Untersuchungen.) $51-61$

Fazekas Imre: Vizsgálatok a Keleti-Mecsek nagylepke faunáján. IV. Magyaregregy lepkéi (Lepidoptera). (Untersuchungen über die Makrolepidopterenfauna des Östlichen Teils des Mecsekgebirges (SW-Ungarn) IV. Die Schmetterlinge von Magyaregregy.) .. 63-76

Gaál Sándor, Füzesi István \& Pénzes Bethen: A balatoni, dunai és tiszai halak nehézfém tartalma az 1979-1982 közötti időszakban. (Der Schwermetallgehalt der Fische im Balaton, in der Donau und in der Theiss zwischen 1979-1982.) $77-84$

Gulyás Pál: Zooplankton vizsgálatok a Lázbérci-tározó nyílt vizében. (Zooplanktonuntersuchungen im offenen Wasser des Lázbérci-Speichers.) .......... 85-92

Harka Ákos: A harcsa (Silurus glanis L.) növekedése a Tiszában. (Das Wachstum des Welses (Silurus glanis L.) in der Theiss.) 93-101

Holdas Sándor: Új hústermelésre alkalmas nyúlfélék a trópusokon. (New leporides suitable for meat production in the tropics.) 103-107 
Kordos László: A Magyar-Középhegység gerinces faunájának fejlődése az elmúlt tízezer évben. (The evolution in the past ten thousand years of the vertebrate fauna of the Hungarian Central Mountain Range.) 109-117

Kozár Ferenc: Újabb adatok Magyarország pajzstetü faunájának (Homoptera: Coccoidea) ismeretéhez. (Kiegészítések a Faunafüzethez, I). (Recent data to the knowledge of the scale-insect (Homoptera: Coccoidea) fauna of Hungary.) 119-131

Láng István: A madártani kutatások jelentősége napjainkban. (The significance of ornithological researches in our days.) $133-135$

Majer József: Szarvasmarha telepek és legelök bögöly (Tabanidae) faunájának összehasonlító vizsgálata. (Comparative examination of the Tabanidae fauna of cattle farms and a cattle grazing-ground.) $137-143$

Sterbetz István: A daru (Grus grus [L.]) magyarországi vonulásának átalakulása. (The transformation of the character of migration of the crane in Hungary (Grus grus [L., 1758]).) $145-150$

Sziráki György: Migráció és diszperzió mint az életmód része. (Migration and dispersion as parts of the manner of living.) $151-158$

Vargha Béla: Madarak a nemzetközi kereskedelemben. (Birds in the international pet trade.) $159-164$

Uherkovich Ákos: Jelenkori terjedési jelenségek dél-dunántúli nagylepkéknél (Lepidoptera). (Recent expansion of some Lepidoptera in Southern Transdanubia (Hungary).) $165-176$

Andrássy István: Ismét huszonöt új Nematoda faj a magyar faunában. (Once again: twentyfive Nematode species new to the Hungarian fauna.) $177-182$

Fazekas Imre: A Mecsek-hegység faunájára új és ritka lepkefajok (Lepidoptera). (Für die Fauna des Mecsekgebirges (Südungarn) neue und seltene Schmetterlingsarten (Lepidoptera).) $183-185$

Keve András: Magyar kutatók madártani gyüjtései a XIX. és XX. században Brazíliában. [Ornitological collectings of Hungarian researchers in Brasil during the $\mathrm{XIX}^{\text {th }}$ and $\mathrm{XX}^{\text {th }}$ centuries.] $187-188$

Petró Ede: Az Anodonta woodiana woodiana (Lea, 1834) kagyló megjelenése Magyarországon. (Occurrence of Anodonta woodiana (Lea; 1834) (Bivalvia: Unionacea) in Hungary.) 189-191

Ponyi Jenő, Issa, Ali \& Zarok, Ali: A keszegivadékok (Abramis brama L.) hosszúsági és súlyviszonyai a Balatonban. (The length- and weight conditions of the bream fry in Lake Balaton.) 193-195

Nógrádi Sára \& Uherkovich Ákos: Malicky, Hans: Atlas of European Trichoptera. (Dr. W. Junk Publisher, The Hague-Boston-London, 1983. X + 273 oldal). [Book review.] .. 197

Dely Olivér György: Penzlin, Heinz: Lehrbuch der Tierphysiologie. (Dritte, überarbeitete und ergänzte Auflage). (VEB Gustav Fischer Verlag, Jena, 1980. 566 oldal, 314 ábrával és 46 táblázattal). [Book review.] 197-198 
Dely Olivér György: Berg, Rolf: Angewandte und topographische Anatomie der Haustiere. (Zweite, überarbeitete Auflage). (VEB Gustav Fischer Verlag, Jena, 2. 428 oldal, 201 ábrával és 23 táblázattal). [Book review.] 198

Stohl Gábor: Wenzel, Ulf Dieter: Pelztiergesundheitsdienst. (VEB Gustav Fischer Verlag, Jena, 1982. 254 oldal, 42 ábrával és 14 táblázattal). [Book review.] 198-199

Vargha Béla: Woodroffe, Gordon: Wildlife conservation and the modern zoo. (Saiga Publishing Co., Hindhead, Surrey, England, 1981. XI. + 208 oldal, 48 fekete-fehér fényképpel). [Book review.] 199

Vargha Béla: Kurt, Fred: Naturschutz - Illusion und Wirklichkeit. (Paul Parey Verlag, Hamburg-Berlin, 1982. 216 oldal, 71 ábrával és 50 fekete-fehér fényképpel). [Book review.] 199

Vargha Béla: Comfortable quarters for laboratory animals. (Animal Welfare Institute, Washington, 1979. 108 oldal, 29 ábrával és 172 fekete-fehér fényképpel). [Book review.] 200

Vargha Béla: Nilsson, Greta: The bird business. (The Animal Welfare Institute, Washington, 1981. IX + 121 oldal, 9 ábrával, 42 fekete-fehér és 30 színes fényképpel). [Book review.] 200-201

Vargha Béla: Lint, Kenton C. \& Lint, Alice Marie: Diets for birds in captivity. (Blandford Press, Poole, Dorset, U. K., 1981. X + 222 oldal). [Book review.] 201

Vargha Béla: Pasquier, Roger F.: Conservation of New World parrots. (Proceedings of the ICBP Parrot Working Group Meeting, St. Lucia, 1980. Smithsonian Institution Press, Washington, 1981. XIII + 485 oldal, 16 ábrával). [Book review.] 201-202

Demeter András: Szakosztályunk ülései. [Sessions of our section.] 203-207

\section{2. kötet - 1985}

1-4. füzet:

A DR. KONRAD LORENZ 80. SZÜLETÉSNAPJA ALKALMÁBÓL RENDEZETT EMLÉKÜLÉS ELÖADÁSAI

Holdas Sándor: Konrad Lorenz életútja. (Der Lebensweg von Konrad Lorenz.) ........... 3-6

Czakó József: A Lorenzi etológiai koncepció alkalmazása a gazdasági állatok tartásában. [The application of Lorenz's ethological conception in economic stock-breeding.]

7-9

Szidnainé Csete Ágnes: Összehasonlító etológiai vizsgálatok a gyermeklovaglás oktatásához használt lófajtákon. (Vergleichende ethologische Untersuchungen an den zum Reitunterricht der Kinder benutzten Pferderassen.) 11-17

Lukács Dezső: Száz éve született Bálint Sándor. (Sándor Bálint wurde vor 100 Jahren geboren.) 19-20

Bankovics Attila: 90 éves a Magyar Madártani Intézet. $\left(90^{\text {th }}\right.$ anniversary of foundation of the Hungarian Institute of Ornithology.) $21-26$ 
Csörgő Tibor \& Andrikovics Sándor: A szitakötők (Odonata) jelentősége a nádi énekesmadarak táplálkozásában. (Importance of dragon-flies (Odonata) in the alimentation of reed-songsters.) $27-31$

Dévai György \& Preczner Zsófia: Új lehetőségek az árvaszúnyogok (Diptera: Chironomidae) taxonómiai kutatásában. III. Enzimológiai vizsgálatok. (Neue Möglichkeiten in der taxonomischen Erforschung von Zuckmücken (Diptera: Chironomidae) III. Enzymologische Untersuchungen.) $33-45$

Domokos Tamás \& Kovács Gyula: A hazai sapkacsigák Békés megyei elterjedése és pásztázó mikroszkópos vizsgálata. (Die Verbreitung der einheimischen Kappenschnecken im Komitat Békés und ihre Untersuchung mit dem SEM-Mikroskop.) $47-51$

Faragó Sándor: Izolálódott túzokpopulációk védelmének kérdései a Kárpát-medence nyugati túzoknépességeinek példáján. (Problems of protection of isolated bustard populations (On the example of the bustard populations at the western part of the Carpathian Basin).) $53-60$

Fazekas Imre: Vizsgálatok a Keleti-Mecsek lepkefaunáján. V. A zengővárkonyi gesztenyés lepkéi. (Untersuchungen über die Lepidopteren Fauna des östlichen Teiles des Mecsekgebirges (SW-Ungarn) V. Die Schmetterlinge (Lepidoptera) des Kastanienwaldes von Zengővárkony.) $61-71$

Gulyás Pál: Néhány dunai zooplankton faj hőtűrőképességének vizsgálata. (Untersuchung der Wärmetoleranzfähigkeit einiger Zooplanktonarten der Donau.) ..................... 73-76

Győry Jenő: A madárvédelem időszerü kérdései hazánkban. (Die aktuellen Fragen des Vogelschutzes in Ungarn.) $77-80$

Kádár Zoltán: Bél Mátyás "De re rustica" című müvének jelentősége a Kárpát-medence faunájának kutatásában. [The importance of Mátyás Bél's work "De re rustica" in the faunistics of the Carpathian Basin.] $81-83$

Kalotás Zsolt: Újabb adatok az egerészölyv (Buteo buteo L.) táplálkozásához. (New data on alimentation of buzzards (Buteo buteo).) 85-93

Kiss István \& Jáger Ferenc: Atrazin kezelés hatása a talaj mezofaunájának tevékenységére. (Effect of Atrazine treatment on soil mesofauna.) 95-100

Korsós Zoltán: Niche-vizsgálat gyíkokon: elmélet és egy példa. (Niche investigations on lizards: theory and an example.) $101-107$

Sterbetz István: Adatok a magyar alföldi szélmalomromok gerinces állatvilágáról. (Data on the vertebrate fauna of windmill ruins on the Great Hungarian Plain.) 109-114

Tátrai István: A Chironomus lárvák szerepe az iszap tápanyag felszabadításában a Balatonban. (The role of Chironomid larvae in the nutrients release from the sediment of Lake Balaton.) 115-121

G. Tóth László \& P. Zánkai Nóra: A balatoni Cyclops vicinus (Uljanin) (Copepoda: Cyclopoida) táplálkozásának vizsgálata béltartalom analízisek alapján. (Feeding of Cyclops vicinus (Uljanin) (Copepoda: Cyclopoida) in Lake Balaton on the basis of gut content analyses.) $123-134$ 
Török János \& Tóth László: A táplálékért folyó versengés kísérletes vizsgálata cinegepopulációkban. (Competition for food: Removal experiment with tits in breeding season.) $135-143$

Andrássy István: Egy igazán különös fonálféreg. (Nimigula unica gen. n., sp. n.) (A truly remarkable Nematode.) $145-150$

Dely Olivér György: Adatok a magyarországi kígyók postcraniális csontvázának ismeretéhez. (Angaben zur Kenntnis des Postcranialskelettes Ungarischer Schlangenarten.) $151-152$

Poddubnaya, T. L. \& Ponyi Jenő: Újabb adatok a Balaton Oligochaeta faunájáról. (New data on the Oligochaeta fauna of Lake Balaton.) $153-156$

Mészáros Ferenc: Kassai, Tibor: Handbook of Nippostrongylus brasiliensis (Nematoda). (Commonwealth Agricultural Bureaux és Akadémiai Kiadó, Budapest, 1982. 257 oldal, 52 ábra, 13 táblázat). [Book review.]

Papp Jenő: Steinmann Henrik és Zombori Lajos: A rovartest alaktani kifejezései. I. A fej. (Biológiai Tanulmányok, 10. Akadémiai Kiadó, Budapest, 1984. 200 oldal). [Book review.] $157-158$

Dely Olivér György: Schildmacher, Hans: Einführung in die Ornithologie. Aus dem Nachlass herausgegeben von Dr. Holle Greil. Bearbeitet und erweitert von H. Oehme und H. Greil. (VEB Gustav Fischer Verlag, Jena, 1982. 283 oldal, 70 ábrával és 16 fényképtáblával). [Book review.]

Dely Olivér György: Magyar madártani bibliográfia. Bibliographia ornithologica hungarica. Összegyüjtötte: Papp József. Szerkesztette: Réthy Zsigmond. (Kiadja a Békés megyei Tanács VB Környezet- és Természetvédelmi Bizottsága és a Megyei Tudományos Koordinációs Bizottság, D. [Book review.] $158-159$

Stohl Gábor: Dunbar, Robin \& Dunbar, Patsy: Social dynamics of gelada baboons. (S. Karger Verlag, Basel-München-Paris-London-New York-Sydney, 1975. VIII + 157 oldal, 46 ábrával és 37 táblázattal). [Book review.]

Stohl Gábor: Állattenyésztési kísérletek tervezése és értékelése (szerkesztette: Czakó József). (Akadémiai Kiadó, Budapest, 1982. 545 oldal, 86 ábrával és 106 táblázattal). [Book review.] $159-160$

Stohl Gábor: Brain-endocrine interaction. II. The ventricular system in neuroendocrine mechanisms. (Szerkesztők: Knigge, K. M., Scott, D. E., Kobayashi, H. \& Ishii, S.) (S. Karger Verlag, Basel-München-Paris-London-New York-Sydney, 1975. IX + 406 oldal, 181 ábrával é. [Book review.] 160

Demeter András: Szakosztályunk ülései. [Sessions of our section.] $161-165$ 


\section{3. kötet - 1986}

1-4. füzet:

Bozsko Szvetlana: A magyarországi urbán ornitofauna vizsgálata és ennek természetvédelmi vonatkozásai. (A study of the Hungarian urban ornithofauna and its significance for nature conservation.) $3-10$

Domokos Tamás: Adatok Békéscsaba malakofaunájának kialakulásához. (Beiträge zur Entstehung der Malakofauna von Békéscsaba.) 11-19

Faragó Sándor: Magyarország túzokállománya az 1981-1985. évi állományfelmérések tükrében. (The bustard population of Hungary in light of the 1981-1985 censuses.)

$21-28$

Fazekas Imre: Adatok a Pterophorus leucodactylus Denis \& Schiffermüller és az Agriphila tolli pelsonius Fazekas ismeretéhez (Lepidoptera: Pterophoridae et Pyralidae). (Beiträge zur Kenntnis von Pterophorus leucodactylus Denis \& Schiffermüller und Agriphila tolli pelsonius Fazekas (Lepidoptera: Pterophoridae, Pyralidae).) 29-32

Kőműves László, Fónagy Adrien \& Sass Miklós: A gyapotpoloska (Dysdercus cingulatus) petéi fejlődésének hisztológiai és ultrastrukturális vizsgálata. (A histological and ultrastructural study of the ovarian development of the red cotton bug, Dysdercus cingulatus (Insecta, Hemiptera).) $33-43$

Kovács György: Felnőtt mezeinyulak túlélési mintázata. [Surviving pattern of adult European hares.] ......................................................................................... 45-49

Moskát Csaba: Madárszámlálási módszerek hatékonyságának vizsgálata a Pilishegységben. (Efficiency of some bird census methods in the Pilis mountains.) .... 51-59

Papp László: A taxonómia és a szisztematika viszonyáról. (On the relationship of taxonomy and systematics.) $61-68$

Ponyi Jenő \& H. Péter Ilona: Az Eudiaptomus gracilis (G. O. Sars) napszakos vertikális vándorlása a Balatonban. (Vertical circadian movement of Eudiaptomus gracilis (G. O. Sars) in lake Balaton.) 69-77

Sterbetz István: Az Örvöslúd (Branta bernicla) és az apácalúd (Branta leucopsis) mozgalmának alakulása Magyarországon. (Records of brent goose (Branta bernicla) and barnacle goose (Branta leucopsis) in Hungary.) 79-83

Székely Tamás: A harkályok, a csuszka és a fakusz táplálkozási viselkedése télen és tavaszszal. (Foraging behaviour of woodpeckers (Dendrocopos spp.), Nuthatch (Sitta europaea) and treecreeper (Certhia sp.) in winter and in spring.) 85-93

Tátrai István, G. Tóth László, Istvánovics Vera \& Ponyi Jenő: A dévérkeszeg (Abramis brama L.) hatása az alacsonyabb trofikus szintekre és a víz minőségére a Balatonban. (The effects of Bream (Abramis brama) on the lower trophic levels and on water quality in lake Balaton.) 95-100

Török János \& Csorba Gábor: Táplálék szegregáció négy fatörzsön táplálkozó madárfajnál. (Food segregation among four bark-foraging bird species.) 101-113 
Andrássy István: Egy új tüfonálféreg faj Magyarországról: Paralongidorus rex sp. n. (Nematoda: Longidoridae). (Paralongidorus rex sp. n., a new nematode species from Hungary.) $115-118$

Dely Olivér György: Megjegyzések a parlagi vipera (Vipera ursinii rakosiensis Méhely, 1893) szlavóniai elterjedéséhez. (Bemerkungen zum Vorkommen der Spitzkopfotter (Vipera ursinii rakosiensis Méhely, 1893) in Slawonien.) $119-120$

Fazekas Imre: Egy új Crambinae faj, a Crambus monochromellus Herrich-Schäffer, 1852 Magyarországon (Lepidoptera: Pyralidae). (Crambus monochromellus HerrichSchäffer, 1852, Eine neue Crambinae-Art in Ungarn (Lepidoptera: Pyralidae).)

Harka Ákos: Újabb adatok a Gobio kessleri Dybowski, 1862 (Pisces: Cyprinidae) magyarországi előfordulásáról és élőhelyi viszonyairól. (Neuere Angaben zum Vorkommen von Gobio kessleri Dybowski, 1862 (Pisces: Cyprinidae) in Ungarn und zu seinen Biotopverhältnissen.) $125-127$

Paasivirta, Lauri \& Tátrai István: Néhány adat a balatoni árvaszúnyog (Diptera: Chironomidae) faunáról. (Some data on the chironomid fauna (Diptera: Chironomidae) from lake Balaton.) $129-131$

Andrássy István: Mahunka Sándor (szerk.): The Fauna of the Kiskunság National Park. I. (Akadémiai Kiadó, Budapest, 1986, 491 oldal). [Book review.] 133

Andrássy István: Soós Árpád (szerk.): Catalogue of Palaearctic Diptera. 11-12. (Akadémiai Kiadó és Elsevier Science Publishers, Amsterdam, 1986. 11. kötet: 346 oldal, 12. kötet: 275 oldal). [Book review.] 134

Andrássy István: Heinrich Dathe \& Paul Schöps: Pelztieratlas. (VEB Gustav Fischer Verlag, Jena, 1986, 323 oldal, 202 fényképpel és 177 elterjedési ábrával). [Book review.] 134

Demeter András: Szakosztályunk ülései. [Sessions of our section.] $135-142$

\section{4. kötet - 1987}

1-4. füzet:

Balogh János: Kaszab Zoltán emlékezete. [In memoriam Zoltán Kaszab.]

Bakonyi Gábor: Fábián Gyula emlékezete. [In memoriam Gyula Fábián.]

Fazekas Imre: Adatok Magyarország Pterophoridae faunájának ismeretéhez. 4. DélDunántúl Pterophoridae fajai és elterjedésük (Lepidoptera). (Beiträge zur Kenntnis der Pterophoridae-fauna Ungarns (4). Die Federmotten Süd-Transdanubiens und ihre Verbreitung (Lepidoptera).) $17-28$

Fischer Antal: A 120 éves Budapesti Állatkert rövid krónikája. (Seltene Tierarten im 120 Jahre alten Budapester Zoologischen Garten.) $29-33$

Holdas Sándor: 120 éves a Budapesti Állatkert. (The Budapest Zoo is 120 years old.) 35-39 
Horváth Zoltán \& Németh Ferenc: Újabb adatok a napraforgón károsító Agapanthia dahli Richt. (Coleoptera: Cerambycidae) biológiájához. (Neuere Daten zur Biologie des Sonnenblumenschadlings Agapanthia dahli Richt. (Coleoptera: Cerambycidae).) 41-48

Husvár László: Roy P. Mackal professzor kongói dinosaurus felfedezéséről. (Professor Roy P. Mackal's dinosaurus discovery in the Congo.) 49-54

Jakab Béla: A fehér gólya (Ciconia ciconia) magyarországi populációjának helyzete és védelme, 1958 és 1984 között. (Lage und Schutz der Population des Weissen Storches (Ciconia ciconia) in Ungarn 1958-1984.) 55-63

Kalotás Zsolt: A vetési varjú (Corvus frugilegus L.) hazai állományának felmérése 1984 tavaszán. (Bestandaufnahme der Saatkrähe (Corvus frugilegus L.) in Ungarn im Früjahr 1984.) $65-76$

Ludvig Éva \& Török János: A fekete rigó táplálékkereső stratégiája. (Foraging strategy of the blackbird.) $77-87$

Majer József: Tabanidae fajok gazdapreferenciájának vizsgálata állatkertben. (Host preference of tabanid species in a zoo.) 89-95

Mészáros Zoltán: Lepkevándorlások kutatása és azok gyakorlati jelentősége. (Die Wanderfalterforschung und die praktische Bedeutung der Forschungen.) 97-105

B. Muskó Ilona: Fény- és elektronmikroszkópos vizsgálatok Cyclops vicinus emésztőcsatornáján. (Light and electron microscope studies on the alimentary canal of Cyclops vicinus.) 107-119

Sterbetz István: A vörösnyakú lúd (Branta ruficollis Pall.) vonuló állományának vizsgálata Magyarországon. (A study of the migration of the Red-breated Goose, Branta ruficollis (Pallas, 1769) in Hungary.) $121-127$

Stohl Gábor: Megfigyelések rágcsáló emlősök szaporodásbiológiájával kapcsolatban. (Fortpflanzungsbiologische Beobachtungen an Nagetieren.) $129-138$

Tátrai István, G. Tóth László \& Istvánovics Vera: Halak hatása az elsődleges termelőkre és a tápanyag-dinamikára limnokorallban. (Fish influence on primary producers and nutrient dynamics in limnocorrals.) 139-148

G. Tóth László, Drits, Alexander V. \& Semenova, Tatjana Ny.: Az antarktiszi világítórák (Euphausta superba Dana) táplálkozásának vizsgálatai a Déli Shetland-szigetek körzetében (Atlanti óceán). (Studies on the feeding of Euphausia superba (Dana) in the region of South Shetland Islands (South Atlantic Ocean).) 149-157

Visnyovszky Éva: Agrárterületek - kukorica és alma - zengőlégy (Diptera: Syrphidae) faunájának összehasonlító vizsgálata. (Comparison of the hoverfly (Diptera: Syrphidae) faunas of agricultural lands: maize fields and apple-yards.) 159-167

P. Zánkai Nóra: A rákplankton összetétele és sürüsége a Balaton nyílt vizében és a partközelben. (Composition and density of crustacean plankton in the open water and in the littoral zone of lake Balaton.) 169-181

Andrássy István: Egy új Tylolaimophorus faj (Nematoda) Magyarországon. (A new species of the genus Tylolaimophorus (Nematoda) from Hungary.) $183-186$ 
Vargha Béla: Streble, Heinz és Krauter, Dieter: Das Leben im Wassertropfen. Mikroflora und Mikrofauna des Süsswassers. (Kosmos Gesellschaft der Naturfreunde, Franckh'sche Verlagshandlung, Stuttgart, 1985. 7. kiadás, 367 oldal, 1700 fekete-fehér ábrával, 25 fekete-fehér ábrával, 25 fekete-fehér és 27 színes fényképpel). [Book review.] 187

Vargha Béla: Engelhardt, Wolfgang: Was lebt in Tümpel, Bach und Weiher? Pflanzen und Tiere unserer Gewasser in Farben. (Kosmos Gesellschaft der Naturfreunde, Franckh'sche Verlagshandlung, Stuttgart, 1986. 12. átdolgozott kiadás, 270 oldal, 347 színes és 58 fekete-fehér ábrával, 18 színes fényképpel). [Book review.] $187-188$

Vargha Béla: Campbell, Andrew, C.: Was lebt im Mittelmeer? Pflanzen und Tiere der Mittelmeerküsten in Farben. (Kosmos Gesellschaft der Naturfreunde, Franckh'sche Verlagshandlung, Stuttgart, 1983. 320 oldal, 1145 nagyrészt színes ábrával, 1 színes térképpel). [Book review.] 188

Vargha Béla: Campbell, Andrew, C.: Das Kosmos-Strandführer. Pflanzen und Tiere der europäischen Küsten in Farben. (Kosmos Gesellschaft der Naturfreunde, Franckh'sche Verlagshandlung, Stuttgart, 1977. 320 oldal, 848 színes és 109 fekete-fehér ábrával). [Book review.] 188

Vargha Béla: Sandhall, Ake és Berggren, Hans: Planktonkunde. Bilder aus der Mikrowelt von Teich und See. (Kosmos Gesellschaft der Naturfreunde, Franckh'sche Verlagshandlung, Stuttgart, 1985. 107 oldal, 238 színes és 12 fekete-fehér fényképpel, 122 fekete-fehér ábrával). [Book review.] 189

Vargha Béla: Hausmann, Klaus és Patterson, David, J.: Taschenatlas der Einzeller: Protisten, Arten und mikroskopische Anatomie. (Kosmos Gesellschaft der Naturfreunde, Franckh'sche Verlagshandlung, Stuttgart, 1983. 71 oldal, 121 színes fényképpel és 116 fekete-fehér ábrával). [Book review.] 189

Loksa Imre: Móczár László: Rovarbölcsők. (Gondolat Könyvkiadó, Budapest, 1987. 180 oldal, 178, nagyobbrészt színes fényképpel). [Book review.] $189-190$

Stohl Gábor: Böhme, W. (ed.): Handbuch der Reptilien und Amphibien Europas: Band 2/1. Echsen II (Lacerta); Band 2/2. Echsen III (Podarcis). (Aula-Verlag, Wiesbaden, 1984, 416 oldal, 47 ábrával, illetve 1986, 435 oldal, 64 ábrával). [Book review.] 190-191

Kádár Zoltán: Luther, Dieter: Die ausgestorbenen Vögel der Welt. 3. überbearbeitete Auflage. (Die Neue Brehm-Bücherei, A. Ziemsen Verlag, Wittenberg-Lutherstadt, 1986. 203 oldal). [Book review.] 191-192

Stohl Gábor: Mowat, Farley: Sea of Slaughter. (McCelland and Stewart, Toronto, Ontario, 1984. 438 oldal). (Mowat, farley: sea of slaughter) 192-193

Kiss István: Szakosztályunk ülései. [Sessions of our section.] 195-200 


\section{5. kötet - 1989}

1-4. füzet:

Mahunka Sándor: 75 éves az Állattani Közlemények. [Állattani Közlemények is 75 years old.] ......

Lukács Dezső: Emlékezés Farkas Béla professzorra (1884-1967). (In commemoration of prof. Béla Farkas.)

Bende Sándor, ifj.: Kísérletes haemorrhagiás és endotoxin sokk hatásának összehasonlító ultrastrukturális vizsgálata kutyák zsigeri szervein. [Comparative ultrastructural study of the effect of experimental haemorrhagic and endotoxic shock on the visceral organs of dogs.]

Faragó Sándor: A vonuló és telelő vízimadár fauna felmérése a Duna magyarországi középső szakaszán (1791-1708 fkm). (A survey of wildfowl staging and wintering on the middle section of the river Danube in Hungary.) $29-42$

Fazekas Imre: A Dél-Dunántúl Crambinae fajai és elterjedésük (Microlepidoptera). (Die Crambinae-Arten und ihre Verbreitung in Süd-Transdanubien (Microlepidoptera).)

43-48

Harka Ákos: A Zagyva vízrendszerének halfaunisztikai vizsgálata. (Fischfaunistische Untersuchung des Wassersystems der Zagyva.) 49-58

Hertelendy Péter \& Mészáros Zoltán: A különböző égők hatása egy tíz éven át működő fénycsapda fogási eredményeire. (Wirkung verschiedener Glühbirnentypen auf die Fangergebnisse einer zehn Jahre lang benutzten Lichtfalle.) 59-63

Lőrincz Gábor, Demeter András, Mahunka Sándor \& Moskát Csaba: Országos élővilág adatbank a Természettudományi Múzeumban. [National database of biota in the Natural History Museum.] $65-78$

Majer József: A fajok új, komplex gyakorisági indexe, az ISA alkalmazása a szarvasmarha legelők bögölyfaunája kutatásában. (The use of a new complex abundance index, ISA, in the study of the tabanid fauna of cattle pastures.) 79-86

Sterbetz István: A nagy lilik (Anser albifrons Scop., 1769) állományai a magyarországi vadlúdtömegekben. (Population problems of the White-fronted Goose Anser albifrons (Scop., 1769) among other goose species in Hungary.) 87-93

Szép Tibor: Madárgyürüzési adatok számítógépes adatbankja. (Computerized data bank of Hungarian ringing data.) 95-105

Szontagh Pál: Rovarok okozta károk bükköseinkben. (Probleme der Insektenschäden in unseren Buchenwäldern.) 107-112

Vásárhelyi Tamás: Két hazai zoológiai egyesület müködésének összehasonlítása. (Comparison of the acitivities of two Hungarian zoological societies.) 113-126

P. Zánkai Nóra: Rotatoria plankton a Balaton nyílt vízében 1984-85-ben és átalakulása az utóbbi 20 évben. (The Rotatoria plankton in the open water of lake Balaton in 1984-85 and its changes during the last 20 years.) $127-141$ 
Andrássy István: További huszonöt Nematoda faj a magyar faunában. (Twenty-five nematode species new for the Hungarian fauna.) $143-145$

Fazekas Imre: A Catoptria persephone Bleszynski, 1965 előfordulása Magyarországon (Lepidoptera: Crambinae). (Catoptria persephone Bleszynski, 1965).) $147-150$

Forró László: Moina salina Daday, 1888: új ágascsápú rák Magyarországon (Crustacea: Cladocera). (Moina salina Daday, 1888: a new species for the Hungarian fauna.) $151-154$

Kiss István: Szakosztályunk hírei. [News of our section.] $155-159$

\section{6. kötet - 1990}

1-4. füzet:

Kádár Zoltán: Emlékezés Pongrácz Sándorra (1887-1945). [In memoriam Sándor Pongrácz (1887-1945).]

Lukács Dezső: Horváth Andor 75. születési évfordulójára. [On the $75^{\text {th }}$ birthday of Andor Horváth.]

9-11

Jánossy Dénes: Lambrecht Kálmán, a paleontológus. [Kálmán Lambrecht, the paleontologist.] $13-16$

Andrássy István: Szabadon élő fonálférgek (Nematoda) a magyar faunában. (Free-living Nematoda in the Hungarian fauna.) $17-38$

Demeter András \& Csorba Gábor: Hány vakond faj él Magyarországon? (How many mole species occur in Hungary?) 39-49

Faragó Sándor: A kemény telek hatása Magyarország túzok (Otis tarda L.) állományára. (The effect of heavy winters on bustard (Otis tarda) populations in Hungary.) ..... 51-62

Gubányi András: Összehasonlító populáció-szerkezeti vizsgálat a kecskebéka fajcsoportnál (Rana esculenta complex). (Comparative analysis on the population structure of the Hungarian water frogs.) 63-71

Papp Jenő: J. Waage \& D. Greathead (szerk.): Insect parasitoids (Rovar parazitoidok). Academic Press (Harcourt Brace Jovanovich), London etc., 1986. 389 oldal. [Book review.] $71-72$

Kiss J. Botond, Rékási József \& Sterbetz István: Magyarországi és romániai adatok a sárszalonka fajok táplálkozásáról. (The food of snipe species in Hungary and Romania.) $73-78$

Lőw Péter, Török János, Sass Miklós \& Csörgő Tibor: Kétéltűek táplálkozásökológiája a Kis-Balaton természetvédelmi területén. (Feeding ecology of amphibians in the KisBalaton nature reservation.) 79-89

Ponyi Jenő: Az Unionidae család (Mollusca, Bivalvia) elterjedése, tömege és produkciója a Balatonban. (Distribution, biomass and production of mussels of the family Unionidae (Mollusca, Bivalvia) in the lake Balaton.) 91-97 
Puky Miklós, Bakó Botond \& Krolopp András: A barna varangy vándorlási sajátosságainak vizsgálata. (Untersuchung des Migrationsverhaltens der Erdkröte.) 99-104

P. Zánkai Nóra: Megemlékezés Dr. Varga Lajos (1890-1963) a Balatonon és környékén végzett kerekesféreg-kutatásairól. (Erinnerung an die im Balaton und in seiner Umgebung durchgeführten Rotatoria-Forschungen von dr. Lajos Varga.) $105-108$

Andrássy István: A magyar zoológusok névjegyzéke. (Register of the Hungarian zoologists.) $109-130$

Kiss István: Szakosztályunk ülései. [Sessions of our section.] $131-136$

\section{7. kötet - 1991}

\section{1-4. füzet:}

Kádár Zoltán: Emlékezés Lukács Dezsőre (1913-1989). [In memoriam Dezső Lukács (1913-1989).] 3-10

Szidnainé Csete Ágnes: Nádler Herbert életútja és munkássága. [The life and work of Herbert Nádler.] $11-16$

Dózsa-Farkas Klára: Magyarországi tőzegmoha-lápok televényféreg faunájáról (Oligochaeta: Enchytraeidae). (The Enchytraeida (Oligochaeta: Enchytraeidae) fauna of the sphagnum bogs in Hungary.) $17-23$

Dózsa-Farkas Klára, Márialigeti Károly, Pobozsny Mária \& Zicsi András: Szaprofág gerinctelenek szerepe különböző szerves anyagok lebontásában. (The role of saprophagous invertebrates in the decomposition of various organic matters.) ..... 25-41

Faragó Sándor: Adatok a túzok (Otis tarda L.) csibék anyag- és energiaforgalmának ismeretéhez. (Data in the material and energy turnover of the great bustaro (Otis tarda) chicks.) $43-52$

Fazekas Imre: Adatok a Phalonidia vectisana Humpr. \& Westw. és az Aethes cnicana Westw. magyarországi ismeretéhez (Lepidoptera: Tortricidae, Cochylini). (Angaben zur Kenntnis von Phalonidia vectisana Humphr. \& Westw. und Aethes cnicana Westw. in Ungarn (Lepidoptera: Tortricidae, Cochylini).) 53-58

Jakab Béla: A fehér gólya (Ciconia ciconia) elterjedésének összefüggése a talajtípusokkal Magyarországon. (Connections between sorts of soil and the distribution of the white stork (Ciconia ciconia) in Hungary.) 59-67

Keresztessy Katalin: A menyhal biológiájáról. (On the biology of the Burbot (Lota lota).) 69-78

Kozár Ferenc: A pajzstetvek (Homoptera: Coccoidea) fajösszetételének vizsgálata a Pilis Bioszféra Rezervátum területén. (Assemblage of scale insects (Homoptera: Coccoidea) in the Pilis Biosphere Reservation.) 79-88

Ponyi Jenő: Hidrozoológiai kutatások Magyarországon (1958-1982). (Hydrozoological researches in Hungary (1958-1982).) 89-108 
Sterbetz István: Adatok a daru (Grus grus L., 1758) magyarországi vonulásának növényvédelmi problémáihoz. (The feeding of the Crane (Grus grus) in Hungary and significance for plant protection.) 109-115

Sterbetz István: A Magyarországon átvonuló darvak (Grus grus L., 1758) telelése ÉszakAfrikában. (The wintering of Common Cranes, Grus grus (1. 1758) in North-Africa passage across Hungary.) $117-124$

Szlávecz Katalin: Szárazföldi ászkarákok (Isopoda: Oniscidea) táplálékválasztása laboratóriumi kísérletekben. (Food selection of terrestrial isopods in laboratory experiments.)

$125-133$

Tóth Sándor: Vadgazdálkodásunk és vadászatunk jelene és jövője. [Present and future of our game management and hunting practice.] 135-137

Varga Zoltán: Helyzetelemzés a biogeográfiai - ezen belül állatföldrajzi - kutatásokról. (The present state of situation or biogeographical, within this zoogeographical, investigations.) 139-144

Vásárhelyi Tamás: Beszámoló a Magyar Biológiai Társaság Állattani Szakosztályának 1985-1990 közti munkájáról. [Report on the activity of the Zoological Section of the Hungarian Biological Society between 1985 and 1990.] 145-149

Andrássy István: A Balaton fonálféreg (Nematoda) faunájáról. (On the nematode fauna of lake Balaton.) $151-159$

Endes Mihály: A fenékjáró küllő (Gobio gobio L.) színváltozata. (Eine interessante Farbenvariante von Gobio gobio L.) 161

Loksa Imre: Móczár László: Rovarkalauz. Megjelent 1990-ben a Gondolat Kiadóvállalat gondozásában. Terjedelme: 260 oldal szöveg és 350 fénykép. [Book review.] 162

Kiss István: Szakosztályunk ülései. [Sessions of our section.] $163-170$

\section{8. kötet - 1992}

1. füzet:

Dózsa-Farkas Klára: Dr. Loksa Imre (1923-1992). (Dr. Imre Loksa (1923-1992).) ...... 3-7

Andrássy István: Néhány hazai tőzegmoha-láp fonálférgeiröl (Nematoda). (On the nematode fauna of some sphagnum bogs in Hungary.) 9-19

Faragó Sándor: Magyarország túzokállománya az 1985-1990 évi felmérések tükrében. (The bustard population of Hungary in the light of the 1985-1990 censuses.) ...... 21-28

Fazekas Imre: A Stenoptilia annadactyla Sutter, 1988 és a S. gratiolae Gilbeaux et Nel, 1990 előfordulása Magyarországon (Lepidoptera: Pterophoridae). (The occurrence of Stenoptilia annadactyla Sutter, 1988 and S. gratiolae Gibeaux et Nel, 1990 in Hungary.) 29-31

Harka Ákos: Adatok a Sajó és Hernád vízrendszerének halfaunájáról. (New data on the fish fauna of the Sajó and Hernád river system.) 33-39 
Harka Ákos: Adatok a Bodrog vízrendszerének halfaunájáról. (New data on the fish fauna of the Bodrog river system.) $41-46$

Kovács Tibor \& Török János: Nyolc kétéltủ faj táplálkozásökológiai vizsgálata a KisBalatonon. (The food composition of eight amphibian species in the Kis-Balaton Nature Protection Area, Hungary.) $47-53$

Kováts Krisztián: Barnamedve populációk jelenlegi helyzete. (The present status of the brown bear in Rumania.) ............................................................................... 55-68

Könczey Réka, Török János \& Tóth László: Költéssiker és költési területhűség az örvös légykapónál (Ficedula albicollis). (Breeding success and breeding site fidelity in the collared flycatcher (Ficedula albicollis).) 69-76

Sallai Ágnes: Cönológiai vizsgálatok az Ócsai Tájvédelmi Körzet területén, különös tekintettel a talajlakó makrofauna tagjaira (Diplopoda, Isopoda, Chilopoda). (The investigation of animal communities in the Ócsa Landscape Protection Area with special emphasis on the soil-dwelling macrofauna (Diplopoda, Isopoda, Chilopoda).) 77-87

Sterbetz István: A Vásárhelyi-pusztán fészkelő széki lile populáció (Charadrius alexandrinus L., 1758) elsorvadásának vizsgálata. (The decline of the Charadrius alexandrinus L. 1758 population at Vásárhelyi puszta.) 89-93

Sterbetz István: A tiszavirág (Palingenia longicauda) szerepe a madarak táplálkozásában. (The role of the long-tailed mayfly (Palingenia longicauda) in the diet of birds.) 95-97

Szinetár Csaba: Újdonsült albérlőink, avagy jövevények az épületlakó pókfaunánkban. (Our new lodgers, new immigrants in the building dweller spider fauna in Hungary.) 99-108

Szontagh Pál: A kocsánytalan tölgyek pusztulásában szerepet játszó rügy- és hajtáskártevők. (Sessile oak death causing phytophagous bud and shoot parasites.) 109-115

P. Zánkai Nóra: A Cyclops vicinus (Uljanin) (Copepoda, Cyclopoida) nauplius lárváinak táplálkozásáról. Az elfogyasztható mérettartomány. (On the feeding of Cyclops vicinus (Copepoda: Cyclopoida) nauplius larvae. The size limits of the comsumable particles.)

Dely Olivér György: Proceedings of the 6th Ordinary General Meeting of the Societas Europaea Herpetologica, 19-23 August 1991, Budapest. (Szerk. Korsós Zoltán és Kiss István. A Természettudományi Múzeum, Bp., kiadványa, 1992. 534 oldal, számos melléklettel). [Book review.] 127

Keresztessy Katalin: Szakosztályunk ülései. [Sessions of our section.] $129-136$ 
78. kötet, Supplementum - 1994

Ünnepi kötet. 100 éves az Állattani Szakosztály 1891-1991

Dózsa-Farkas Klára: Elnöki köszöntő. (Welcoming words.) $5-6$

Horváth Csaba \& Korsós Zoltán: 100 éves az Állattani Szakosztály. (100 years in the life of the Zoological Section.) $7-18$

Kádár Zoltán: Az Állattani Szakosztály első tisztikara. (The first officers of the Zoological Section) $19-22$

Vásárhelyi Tamás: 100 év magyar zoológiai expedíciói. (Hungarian zoological expeditions of one hundred years.)

Korsós Zoltán: A parlagi vipera (Vipera ursinii rakosiensis Méhely, 1893) száz éve. (Onehundred years of the meadow viper (Vipera ursinii rakosiensis Méhely, 1893).) .. 31-38

Horváth Csaba \& Korsós Zoltán: Az elmúlt 100 év előadóülései. (Lectures of one hundred years.) 39-177

Horváth Csaba: Az Állattani Szakosztály folyóiratának bibliográfiai adatai a kezdetektől 1991-ig (Könyvészeti leírás). (Bibliographical description of the communications of the Zoological Section from the beginning to 1991.) 179-187

Az Állattani Szakosztály tisztikara 1891-1991. (elnökök, alelnökök és titkárok). [Board members of the Zoological Section 1891-1991.] 188

Az Állattani Szakosztály névsora 1991. novemberében (421 fö). [List of members of the Zoological Section in November 1991.] 189-193

\section{9. kötet - 1993}

1. füzet:

Andrássy István: A Balaton két Mesotheristus faja (Nematoda). (The two limnic species of the genus mesotheristus wieser, 1956 (Nematoda: Xyalidae).) $3-14$

Bába Károly: Gyepek és bokorerdők csiga faunája a Bükk-hegységben. (The malacofauna of rock grasslands and scrub forests in the Bükk mountains.) 15-24

Bilkó Ágnes \& Altbäcker Vilmos: Táplálékpreferencia átadódása az üreginyúlnál. Befolyásolja-e az anya étrendje a kicsik későbbi táplálékválasztását? (Transmission of food preferences at the Wild Rabbit (Oryctolagus cuniculus).) 25-35

Faragó Sándor: Vadlúd állományvizsgálatok 10 éves eredményei a Fertő-tó magyar területrészén: 1983-1993. (The investigation of the goose stock at the Hungarian part of lake Fertö: a ten year study (1983-1993).) $37-47$

Fazekas Imre: Adatok az Agdistis heydeni Z. és a Calyciphora nephelodactyla Ev. magyarországi ismeretéhez (Lepidoptera: Pterophoridae). (Data on the distribution of Agdistis heydeni Zeller, 1852 and Calyciphora nephelodactyla Eversmann, 1844 (Lepidoptera: Pterophoridae) in Hungary.) $49-54$ 
Fenyősi László: A Barcsi Tájvédelmi Körzet madarai (1983-93). (Birds in the Barcs Landscape Protection Area (1983-1993).) $55-66$

Fischer Ernő: Az erythroid sejtek változatai és evolúciójuk a gyürüsférgek körében. (The varieties and development of the erythroid-type cells in annelids.) 67-77

Holdas Sándor, Halmágyi Levente, Majoros Gábor \& Pacs István: A magyarországi éticsiga (Helix pomatia L.) állomány felmérése I. Módszerek és előzetes megfigyelések. (A nation-wide survey of the Hungarian Edible Snail (Helix pomatia L.) population. I. Methods and preliminary observations.) 79-89

Kováts Krisztián: A romániai barnamedve (Ursus arctos) populációk szabályozása. Az ember-medve kapcsolatok és kihatásaik. (The management of the Romanian Brown Bear (Ursus arctos) populations. Man-bear relations and their consequences.) 91-94

Sinkovitsné Hlubik Ilona \& Benkő Zita: Foszforsavészterek hatása a csirkeembrió fejlődésére. (The effect of phosphoric acid esters on the development of chicken embryos) 95-103

Sterbetz István: A rétisas (Haliaeetus albicilla L., 1758) állományának pusztulása a Tisza Csongrád megyei szakaszán. (The extinction of the White-tailed Eagle (Haliaaetus albicilla L. 1785) along the river Tisza in Csongrád county, Hungary.) 105-112

P. Zánkai Nóra: A Balaton északi partjának víziatkái. (Freshwater mites of the northern shore of lake Balaton.) 113-134

Halmágyi Levente \& Szalay-Marzsó László: A 100. évforduló emlékérmeiről. [On the memorial medals of the $100^{\text {th }}$ anniversary.] $135-136$

Juhász Lajos: Újabb adat a tiszai ingola (Eudontomyzon danfordi Regan, 1911) magyarországi előfordulásáról. [A new Hungarian occurrence of the Carpathian Brook Lamprey (Eudontomyzon danfordi Regan, 1911).] 137

\section{0. kötet - 1995}

\section{1. füzet:}

Andrássy István: A Balaton különös Eumonhystera faja (Nematoda: Monhysteridae). (An interesting species of the genus Eumonhystera (Nematoda: Monhysteridae) in Lake Balaton, Hungary.) $3-6$

Bilkó Ágnes \& Altbäcker Vilmos: Táplálékpreferencia átadása az üreginyúlnál. Az információk átadásának vizsgálata. (Transmission of food preference in the rabbit: the means of information transfer.)

Fábián Miklós \& Petersen, Henning: Egy dimetoát hatóanyagú növényvédőszer mellékhatásai a Folsomia fimetaria Linné (Collembola) aktivitására és diszperziójára. (Side effects of the pesticide dimethoate on the activity and spatial distribution of Folsomia fimetaria Linné (Collembola).) 21-34

Fazekas Imre: A magyarországi makrorégiók Cochylini faunája (Lepidoptera: Tortricidae) I. A Dunántúli Dombság. (The Cochylini (Lepidoptera: Tortricidae) fauna of the Hungarian geographical regions I. The Transdanubian Hills.) $35-56$ 
Fenyősiné Hartner Anna: Adatok a Formica rufa hangyacsoport (Hymenoptera: Formicidae) fajainak magyarországi elterjedéséhez. (Data on the distribution of the Formica rufa species group (Hymenoptera: Formicidae) in Hungary.) $57-64$

Gera Pál: A vidra (Lutra lutra L.) zárttéri viselkedése és szaporítása. (The behaviour and breeding of the otter (Lutra lutra L.) in captivity.) 65-70

Horváth Győző: Kisemlősfaunisztikai vizsgálatok a gyöngybagoly (Tyto alba Scop., 1769) köpetanalízise alapján Baranya megyében. (Investigation of the small mammal fauna in Baranya county on the basis of barn owl (Tyto alba Scop. 1769) cast analysis.) ... 71-78

Juhász Lajos \& Vas András: Mesterséges fészekodú telep madártani és természetvédelmi jelentősége egy keményfa ligeterdőben a hajdúsági erdőspusztákon. (The ornithological and nature conservation importance of an artificial nesting hollow colony in a hardwood forest in hajdúsági erdőspuszták.) 79-89

Nagy Sándor \& Somlai Tibor: Adatok a Szatmár-Beregi Tájvédelmi Körzet kétéltü és hüllő faunájához. (Data on the herpetofauna of the Szatmár-Bereg Landscape Protection Area.) 91-97

Ponyi Jenő: Az Eucyclops genus két fajának néhány rendszertani problémája, a Balaton parti övének kutatása alapján. (Taxonomic problems with two species of the Eucyclops genus arising during the investigation of the littoral zone of Lake Balaton.) ....... 99-105

Sterbetz István: Gémeskutak szerepe a magyar puszta madáréletében. (The role of sweeppole wells in the bird life of the Hungarian puszta.) $107-110$

Szidnainé Csete Ágnes: Átkos volt-e a Serák-korszak? Az Állatkerti Részvény Társulattól az Állat- és Növényhonosító Társaság csődjéig. (The Károly Serák era in the history of the Budapest Zoo.)

$111-115$

Keresztessy Katalin: Szakosztályunk ülései. [Sessions of our section.] $117-123$

\section{1. kötet - 1996}

1. füzet:

Bankovics Attila: A túzok (Otis tarda Linné, 1758) állományának növekedése a Kiskunsági Nemzeti Parkban. (Population increase of the Great Bustard (Otis tarda L., 1758) in the Kiskunság National Park.) $3-8$

Báskay Imre, Dobó Zoltán \& Pénzes Bethen: Az amuri kagyló okozta glochidiózis vizsgálata. (Glochidiosis caused by the mussel, Anodonta woodiana woodiana Lea, 1834.) 9-14

Fazekas Imre: A Phycitodes inquinatella (Ragonot, 1888) elöfordulása Magyarországon (Microlepidoptera: Pyralidae). (Phycitodes inquinatella exustella (Ragonot, 1888) in Hungary.) $15-17$

Fenyősi László: A Dráva somogyi szakaszának madárvilága (Non-Passeriformes). (The avifauna of river Dráva in County Somogy.) 19-35 
Gubányi András: Adatok a szigetközi vízibéka populációk (Rana esculenta complex) ismeretéhez. (Contribution to the knowledge of population structure of water frogs in a floodplain of river Danube (Szigetköz, Hungary).) $37-43$

Halmágyi Levente, H. Valter Teréz \& Szalay László: A magyarországi éticsiga (Helix pomatia L.) állomány felmérése 2 . Adatok és megfigyelések az Alföld éti- és ugarcsigáiról (Helix lutescens Rossmässler). (A nation-wide survey of the Hungarian Edible Snail (Helix pomatia L.) population 2. Observations on the Hungarian plain.) 45-58

Holzinger Géza, Kovács Tibor \& Török János: Csigák (Gastropoda) a kis-balatoni kétéltűek (Amphibia) táplálékában. (Gastropods eaten by frogs and toads in the Kis-Balaton nature reserve.) 59-63

Kovács Tibor \& Török János: Minimális mintaszám békák (Anura) táplálékdiverzitásának becsléséhez. (Minimum sample size to estimate the diet diversity of anuran species.) $65-71$

Lanszki József \& Körmendi Sándor: Négy ragadozó emlős faj táplálkozásökológiai vizsgálata a fonói halastó (Somogy megye) körzetében. (Examination of food ecology of four carnivorous mammals in the vicinity of Fonó fish-pond (Somogy Country).) ....... 73-85

László M. Gyula: Gödöllő és környéke nagylepke faunája. (The macrolepidopteran fauna of the Gödöllő region.) 87-104

Ludányi István: Az Apis nem fajai és a mézelő méh (Apis mellifera L.) alfajai. (Recent Apis species and the subspecies of the honey bee (Apis mellifera L.).) $105-121$

Madari Beáta, Kiss István \& Korsós Zoltán: Gödöllő környéki ikerszelvényes (Diplopoda) közösségek ökofaunisztikai vizsgálata. (Millipede (Diplopoda) communities in the area of Gödöllő.) $123-129$

Mézes Miklós, Horváth László, Látits Miklós \& Tóth Attila: A halak ováriumának szekszuálszteroid szekrécióját befolyásoló egyes tényezők vizsgálata zebradánió (Brachydanio rerio) modellen. (Investigation into some factors affecting the sexualsteroid production of fish ovary in a Brachydanio rerio model.) $131-135$

Móczár László: Dudich Endre - a faunakutató. (Endre Dudich, the fauna researcher,) $137-140$

Sterbetz István: Primitív háziállat fajták félvad-szerű tartási körülmények között. (Traditional domestic animal types under nomadic conditions.) $141-145$

Sterbetz István: Húsz év erdei szalonka (Scolopax rusticola Linné, 1758) adatai a Pilishegységböl. (Observations on Scolopax rusticola L. in the Pilis mountains.) .... 147-151

Szidnainé Csete Ágnes: Xantus János élete és szerepe a pesti Állatkert alapításában. (János Xantus (1825-1894).) 153-159

Sziráki György: Ketté kell-e osztani az Orthoptera rovarrendet? (Is a splitting of the insect order Ortrhoptera necessary?) 161-163

A BALATON ÁLLATTANI KUTATÁSÁNAK ÚJABB EREDMÉNYEI

Ponyi Jenő: Bevezető. [Introduction.] $167-168$

Andrássy István: Nematológiai kutatások a Balatonon. (Nematological investigations on Lake Balaton.) 169-175 
Andrássy István: Egy igazán ritka fonálféreg (Nematoda) faj a Balatonban. (A very rare nematode species from Lake Balaton.)

Kiss Árpád: A balatoni kagylók növekedése, különös tekintettel az Unio pictorum és $U$. tumidus fajra. (Growth of Unio pictorum and U. tumidus (Mollusca: Bivalvia) in Lake Balaton.) 183-191

Merkl Ottó: A Balaton vízibogarai (Coleoptera). (Aquatic beetles of Lake Balaton (Coleoptera).) 193-198

Ponyi Jenő \& P. Zánkai Nóra: Két ízeltlábú állatfaj felbukkanása a Balatonban. (Two Arthropoda species new to Lake Balaton.) 199-201

Ponyi Jenő \& Szurominé Korecz Andrea: A Balaton kagylósrákjai (Ostracoda). (Ostracoda from Lake Balaton.) 203-209

Szító András, Lakatos Gyula \& B. Muskó Ilona: A Balaton nádbevonataiban élő árvaszúnyogok (Chironomidae). (Periphyton inhabiting chironomid larvae in Lake Balaton.) 211-216

Zsuga Katalin: Vizsgálatok a Balaton litorális övében élő kerekesférgeken (Rotatoria). (Rotatoria in litoral zone of Balaton.) 217-226

Keresztessy Katalin \& Kisbenedek Tibor: Szakosztályunk ülései. [Sessions of our section.] $227-242$

\section{2. kötet - 1997}

1. füzet:

Andrássy István: Elköszönő. [Farewell.] 3

Bakonyi Gábor: Beköszöntő. [Welcoming words.] …......................................................... 4

Delyné Draskovits Ágnes: Dr. Mihályi Ferenc (1906-1997). (Dr. Ferenc Mihályi (1906-1997).) 5-11

Andrássy István: Fonálférgek (Nematoda) a Hévízi-tóban. (Nematodes in the Hévízi Lake (Hungary).) $13-27$

Fazekas Imre: Az Agdistis tamaricis (Zeller, 1847) és a Stenoptilia pneumonanthes (Büttner, 1880) előfordulása Magyarországon (Microlepidoptera: Pterophoridae). (Occurence of Agdistis tamaricis (Zeller, 1847) and Stenoptilia pneumonanthes (Büttner, 1880) in Hungary (Microlepidoptera: Pterophoridae).) 29-38

Dely Olivér György: A csíkos vagy ugró sikló (Coluber caspius Gmelin, 1789) magyarországi elöfordulásáról. (On the occurrence of the Caspian or Balkan Whip Snake (Coluber caspius Gmelin, 1789) in Hungary.) $39-46$

Halmágyi Levente, Majoros Gábor \& H. Valter Teréz: Az éticsiga-kereskedelem magyarországi vonatkozásai és a gyűjtés hatása a hazai csigaállományra. (The trade of Edible Snail in Hungary and the effects of commercial harvest of snails on the inland populations.) $47-58$. 


\section{A BALATON ÁLLATTANI KUTATÁSÁNAK ÚJABB EREDMÉNYEI}

Nedelkovics Aliz \& Ponyi Jenő: Taxonómiai vizsgálatok a balatoni Diaphanosoma egyedeken. (Taxonomical study of Diaphanosoma (Cladocera) specimens coming from Lake Balaton.) $61-64$

Ponyi Jenő, Mezei Szilvia \& Nagy Attila: A Tihany előtti vizekből származó halak parazita rákjainak vizsgálata, 1995-ben. (Studies on the parasitic crustaceans of fish caught from the open water at Tihany.) 65-68

Ponyi Jenő: A Balaton Cladocera és Copepoda rákjai. (Cladocera and Copepoda species (Crustacea) in Lake Balaton.) 69-80

Ponyi Jenő: Egy balatoni növényzetes partszakasz (tihanyi Kis-öböl) rákállományának vizsgálata. (Studies on the crustacean communities in the macrophyte-covered shoreline along Tihany-peninsula.) $81-85$

P. Zánkai Nóra \& Ponyi Jenő: Nyíltvízi planktonrák-együttesek szerkezetének tér- és időbeli változása a Balaton két, trofitásban eltérő területén (Keszthelyi és Siófoki medence). (Changes in the composition and structure of crustacean zooplankton in the open water of two regions of Lake Balaton (Keszthely- and Siófok-basins).) 87-108

Specziár András, Tölg László \& Bíró Péter: A balatoni nádasok halállományának szerkezete. (The fish stock structure of the reed stands in Lake Balaton.) 109-116

Tölg László, Specziár András \& Bíró Péter: A ragadozó őn (Aspius aspius) állományának vizsgálata a Balatonon. (Study on asp (Aspius aspius L.) stocks of Lake Balaton.) $117-123$

Kozár Ferenc: Kosztarab M. (1996): Scale Insects of Northeastern North America. Virginia. Museum of Natural History, Martinsville, 650 p.. [Book review.] 125

Udvardy Miklós: Briggd J. C. (1995): Global Biogeography. Volume 14 of Developments in Palaeontology and Stratigraphy, Elsevier Science Publishers, Amsterdam-New York. 472 p. [Book review.] $126-127$

Kisbenedek Tibor: Az Állattani Szakosztály ülései. (Activity of the Zoological Society.) 129-137

\section{3. kötet - 1998}

1. füzet:

Dely Olivér György: 100 éve született báró Fejérváry Gézáné, dr. Lángh Aranka herpetológus. (Dr. Aranka Lángh (Mrs. Baron G. Fejérváry) herpetologist born 100 years ago.)

3-8

Majoros Gábor: A mételycerkáriákról és azok halkórtani jelentőségéről. Általános áttekintés és a hazai vizsgálatok. (On the cercariae of trematodes and their importance in fish pathology.) 9-28 
Báldi András: Az ökológiai hálózatok elmélete: iránymutató a védett területek és ökológiai folyosók tervezéséhez. (Theoretical considerations in the design of ecological networks.) 29-40

Mészáros Lukács: A magyarországi késő miocén cickányok (Soricidae) paleoökológiai jelentősége. (The paleoecological importance of the Late Miocene shrews (Soricidae) from Hungary.) $41-52$

Korsós Zoltán: Ikerszelvényes-invázó Magyarországon. (Mass occurrence of millipedes (Diplopoda) in Hungary.) $53-65$

Báskay Imre, Pénzes Bethen \& Repkényi Zoltán: Adatok a szúnyogirtó fogasponty (Gambusia affinis holbrooki Girard, 1859) táplálkozásához és szaporodásához hazai körülmények között. (Reproduction biological data of mosquito-fish (Gambusia affinis holbrooki Girard, 1859) and guide numbers for propagation under Hungarian circumstances.) $67-82$

Szentesi György \& Domokos Tamás: A Sr-90 izotóp aktivitásának vizsgálata Helicigona banatica (Gastropoda) és Unio crassus (Bivalvia) mészvázakon - Csernobil utóhatásának indikálása. (Investigations of Sr-90 isotope activity on the shells of Helicigona banatica (Gastropoda) and Unio crassus (Bivalvia) - the aftermath of the Chernobyl accident.) $83-86$

Korsós Zoltán: „Az állattani kutatások története a Kárpát-medencében”. („History of the Zoological Research in the Carpathian Basin" Workshop on the history of science.) $87-88$

Bába Károly: Egy tudós tanár: Czógler Kálmán, a szegedi malakológiai iskola megalapozója. (Kálmán Czógler, the scientist and the teacher: The founder of the Szeged malacological school.) 89-98

Szalainé Mátray Enikő \& Szél Zsuzsanna: Dr. Örösi Pál Zoltán méhészeti kutatásai és munkássága a Kisállattenyésztési Kutatóintézet Méhészetén, Gödöllőn. (Apicultural research and scientific achievement by Dr. Pál Zoltán Örösi at the Honeybee Department of Institute for Small Animal Research in Gödöllö.) 99-103

Merkl Ottó: Robert Townson és a magyar koleopterológia hajnala. (Robert Townson, and the dawn of Hungarian coleopterology.) 105-109

Bába Károly \& Gallé László: A Tisza-völgy zoológiai kutatásának története. (History of the zoological research of the Tisza Valley.) $111-121$

Korsós Zoltán \& Újvári Beáta: A rákosréti vipera Kolozsvár környékén. (The Hungarian Meadow Viper in the vicinity of Cluj.) $123-128$

Venczel Márton: Gerinces ősmaradványok kutatása Biharban. (Vertebrate paleozoological research in Bihar.) 129-134

Vig Károly: Szombathely és Kőszeg környéke faunisztikai feltárásának története (A kezdetektöl napjainkig). (History of the faunistic exploration of the region of Köszeg and Szombathely (From the beginning until 1950).) $135-157$

Nagy Péter: Clayton D. H. \& Moore J. (1997): Host-Parasite Evolution - General Principles and Avian Models. Oxford University Press, 473 p.. [Book review.] ....... 159 
Kisbenedek Tibor: Az Állattani Szakosztály ülései (1997. október 1.-1998. szeptember 16.). (Activity of the Zoological Society (01. 10. 1997.-16. 10. 1998.)) $161-166$

\section{4. kötet - 1999}

1. füzet:

Szentesi Árpád \& Jermy Tibor: A preferencia értékelésének problémái. (On the assessment of preference.) 3-19

Forró László: A kerekfejü vízibolha (Moina brachiata Jurine, 1820) (Crustacea, Cladocera) párzási viselkedése. (Studies on the mating behaviour of Moina brachiata (Jurine, 1820).)

$21-28$

Hufnagel Levente, Bakonyi Gábor \& Vásárhelyi Tamás: Sokváltozós módszerek alkalmazása vízi és vízfelszíni poloskákra (Heteroptera: Nepomorpha és Gerromorpha) alapozott vízminősítési rendszerekben. (Environmental impact assessment of fresh waters by multivariate analysis of the aquatic (Nepomorpha) and semiaquatic (Gerromorpha) bug fauna.) 29-41

Bakó Botond \& Korsós Zoltán: A magyarországi herpetofauna U.T.M.-térképezésének felhasználási lehetőségei. (Nature conservation application of U.T.M. mapping of the Hungarian herpetofauna.) $43-52$

Nagy Zoltán Tamás, Bereczki Zsuzsa \& Korsós Zoltán: Adatok a vízisikló (Natrix natrix L.) populációbiológiájához a szegedi Fehér-tavon. (Contribution to the population biology of the Grass snake (Natrix natrix [L.]) at the Szeged Fehér Lake, Southern Hungary.) 53-62

Horváth Győző: A gyöngybagoly (Tyto alba Scop., 1769) köpetvizsgálatának tíz éve Baranya megyében (1985-1994). (Ten years of Barn owl (Tyto alba Scop., 1769) pellet analysis in county Baranya.) 63-77

Bihari Zoltán: A nagy patkósdenevér (Rhinolophus ferrumequinum) vándorlási szokásai ÉK-Magyarországon. (Migration of great horseshoe bats (Rhinolophus ferrumequinum) in the North-east part of Hungary.) 79-86

Bálint Zsolt: Lepkészeti kutatóúton a perui Andokban. (On a trip studying Lepidoptera in the Peruvian Andes.) 87-101

Nagy Péter: Az Állattani Szakosztály ülései (1998 október 7.-1999. szeptember 8.). (Activity of the Zoological Society (07. 10. 1998.-08. 09. 1999.)) $103-111$

A hazai felsőoktatási intézményekben, a zoológia szakterületén készített doktori (Ph.D.) disszertációk és szakdolgozatok jegyzéke. (List of the Ph.D. dissertations and thesis works related to zoology.) 113-117 


\section{5. kötet - 2000}

1. füzet:

Vásárhelyi Tamás: Elnöki köszöntő az Állattani Szakosztály 900. ülése elé. (Presidential greetings on the occasion of the $900^{\text {th }}$ session of the Zoological Society.) 3-5

Halmágyi Levente: Szalay-Marzsó László emlékezete. (In memoriam László SzalayMarzsó.) $7-16$

Kriska György: Polarotaxis a rovarvilágban. (Polarotaxis of insects.) $17-27$

Kriska György \& Andrikovics Sándor: A kérészek vízdetektálási viselkedése, avagy miért petéznek a kérészek száraz aszfaltutakra? (Water detection of mayflies. Why do mayflies lay their eggs en masse on dry asphalt roads?) 29-42

Bernáth Balázs \& Kriska György: Vízi rovarok polarotaxisának vizsgálata a budapesti pakuratónál. (Investigating the polarotaxis of aquatic insects at the waste-oil lake in $\mathrm{Bu}-$ dapest.) $43-52$

Sárváry Márk, Bakonyi Gábor \& Claassen, Vic P.: A Hemileius initialis (Acari: Oribatida) táplálékválasztása szaprofita és endomikorrhiza gombafajok jelenlétében. (Feeding preferences of the oribatid mite Hemileius initialis (Acari: Oribatida) on saprophytic and mycorrhizal fungi.) $53-58$

Szabó Krisztián, Liker András \& Korsós Zoltán: A fluktuáló aszimetria vizsgálata két magyarországi kockás sikló (Natrix tessellata) populációban. (Comparison of two Dice Snake (Natrix tessellata) populations: an example for measuring fluctuating asymmetry.) 59-68

Ripka Géza: Az amerikai kukoricabogár (Diabrotica virgifera virgifera LeConte, 1868) (Coleoptera: Chrysomelidae) felderítésével kapcsolatos hazai vizsgálatok eredményei. (Results of the monitoring of Western Corn Rootworm (Diabrotica virgifera virgifera LeConte, 1868) (Coleoptera: Chrysomelidae) in Hungary.) $69-78$

Erdey Mercedes, Kiss István \& Foote, Jerris: A tengerpart feltöltődésének hatása az álcserepesteknős (Caretta caretta) fészkelési sikerére. (The effect of beach nourishment on the nesting succes of loggerhead sea turtle, Caretta caretta.) 79-92

Specziár András \& Bíró Péter: Az üledéklakó árvaszúnyog (Diptera, Chironomidae) fauna területi megoszlása és rövid távú változásai a Balatonban 1995 és 1998 között. (Spatial distribution and short-term changes of the benthic chironomid fauna in Lake Balaton during 1995 and 1998.) 93-107

Kertész Virág \& Kovács József: PAH vegyületek hatása a tőkésréce fejlődésére. (The effects of PAH compounds on the embryogenezis of the Mallard.) $109-123$

Nagy Péter: Az Állattani Szakosztály ülései (1999. október 6.-2000. szeptember 6.). (Activity of the Zoological Society (from 06. October 1999 till 06. September 2000).)

A hazai felsőoktatási intézményekben, a zoológia szakterületén készített doktori (Ph.D.) disszertációk és szakdolgozatok jegyzéke. 2000. (List of the Ph.D. dissertations and thesis works related to zoology written in the year of 2000.) $133-135$ 
86. kötet - 2001

1. füzet:

Ponyi Jenő: Áttekintés a Balaton faunisztikai kutatásáról és faunájának összetételéről. (An outline of the faunal research of Lake Balaton and the composition of its fauna.) ... 3-13

Kriska György \& Andrikovics Sándor: A Potamophylax nigricornis (Pict.) és a Potamophylax rotundipennis (Brauer) (Trichoptera, Limnephilidae) lakócsőépítési stratégiája. (New interpretation of the case-building strategy of the Potamophylax nigricornis (PICT.) and Potamophylax rotundipennis (Brauer) (Trichoptera, Limnephilidae).) $15-27$

Rácz István András: Egyenesszárnyú együttesek életforma-spektrumának változása a száraz és félszáraz gyepek struktúrájának függvényében. (Change in the life-form spectra of Orthoptera-communities regarding to the structure of dry and semi-dry grasslands in Hungary.) 29-56.

AZ 1999. AUGUSZTUS 11-I TELJES NAPFOGYATKOZÁS ÉS ZOOLÓGIAI HATÁSAI

Weidinger Tamás, Pintér Krisztina, Hirsch Tamás \& Mészáros Róbert: Az időjárás és a meteorológiai elemek változása az 1999. augusztus 11-i magyarországi teljes napfogyatkozás során. (The weather situation and the meteorological elements during the total solar eclipse of 11 August 1999 in Hungary.) 59-74

Tóth Zoltán: A földfelszínre érkező napsugárzás intenzitásának változása különböző spektrum tartományokon az 1999. augusztus 11-i napfogyatkozás alatt történt mérések alapján. (Change in intensity of solar radiation reaching the Earth's surface in different spectral ranges based on measurements made during the solar eclipse of 11 August 1999.) $75-80$

Bernáth Balázs, Pomozi István, Gál József \& Horváth Gábor: Égboltpolarizáció az 1999. augusztus 11-i teljes napfogyatkozáskor és lehetséges biológiai vonatkozásai. (Skylight polarization during the total solar eclipse of 11 August 1999 and its possible biological implications.) 81-92

Szövényi Gergely, Szentkirályi Ferenc \& Nagy Barnabás: Egyenesszárnyúak és egyéb nappali rovarok aktivitásainak változása az 1999. augusztus 11-i teljes napfogyatkozás alatt. (Change in the activities of orthopterans and other diurnal insects during the total solar eclipse of 11 August 1999.) 93-114

Szentkirályi Ferenc \& Szalay László: Az 1999. augusztus 11-i teljes napfogyatkozás hatása a háziméhek viselkedésére és gyüjtési aktivitására. (The impact of total solar eclipse of 11 August 1999 on behaviour and foraging activities of honeybees.) 115-136

Baldavári László: Méhek viselkedésének változása az 1999. augusztus 11-i teljes napfogyatkozás hatására egy méhészetben. (Effects of the total solar eclipse of 11 August 1999 on behaviour of honeybees, recorded in an apiary.) 137-143

Csörgő Tibor: Madarak napi aktivitásának változásai az 1999. augusztus 11-i napfogyatkozás alatt. (Changes in daily activity of Passerine birds during the total solar eclipse of 11 August 1999.) 145-152 
Nagy Péter: Az Állattani Szakosztály ülései (2000. október 11.-2001. szeptember 5.). (Activity of the Zoological Society (from 11. October 2000 till 05. September 2001).) $153-160$

A hazai felsőoktatási intézményekben, a zoológia szakterületén készített doktori (Ph.D.) disszertációk és szakdolgozatok jegyzéke. 2001. (List of the Ph.D. dissertations and thesis works related to zoology written in the year of 2001.) $161-166$

\section{7. kötet - 2002}

1. füzet:

Bakonyi Gábor: Újabb 100 év elé. (Foreword to the next 100 years.) 3-6

Andrássy István: Az Állattani Közlemények köszöntése. (Greetings to the Zoological Communications.) $7-8$

Vásárhelyi Tamás: Két jubiláns - a 200 éves Magyar Természettudományi Múzeum és a 100 éves Állattani (Two jubilans: the bicentenary of the Hungarian Natural History Museum and the centenary of the Zoological Communications.) 9-20

Korsós Zoltán: A 200 éves Magyar Természettudományi Múzeum Állattára. (A short history of the Department of Zoology, belonging to the 200 years old Hungarian Natural History Museum.) 21-30

Rogovszky Zoltán: Utánpótlás nevelés a Fiatalok Természetismereti Klubjában. (Education of new generations of specialists in the Club of Young Naturalists.) $31-35$

Kiss István \& Seres Anikó: Az Állattani Szakosztály előadóülései és az Állattani Közlemények bibliográfiai adatai (1992-2002). (The Zoological Section of the Hungarian Biological Society: programme of meetings, council members, and bibliographical description of the Zoological Communications (1992-2002).) $37-59$

Mahunka Sándor: Balogh János (1913-2002) emlékezete. (In memoriam János Balogh (1913-2002).) $61-62$

Bíró Péter: A Balaton halállományának hosszúidejű változásai. (Long-term changes in the fish fauna of Lake Balaton (Hungary).) 63-77

Jermy Tibor \& Nagy Barnabás: Állattani kutatások a Növényvédelmi Kutatóintézetben (1880-2002). (Zoology research in the Hungarian Plant Protection Institute, Budapest (1880-2002).) 79-110

Mahunka Sándor: A magyarországi nemzeti parkok kutatása. (Biodiversity researches in Hungarian National Parks.) $111-120$

Papp László: Lehetséges-e a légyfajok védelme Magyarországon? (Is it possible to protect flies in Hungary?) 121-130

Tóth Sándor \& Sáringer Gyula: A Balaton és környékének csípőszúnyog-faunája és az ellenük való védekezés. (Mosquito fauna and prevention against it in the surrounding of Balaton.) 
Dózsa-Farkas Klára: Mit érdemes tudni a televényférgekről (Enchytraeidae, Annelida)? (What should be known about enchytraeids (Enchytraeidae, Annelida)?) 149-164

Csörgő Tibor \& Halmos Gergő: Átkelés a Mediterraneumon - Pihenőhelyek szerepe a madárvonulásban. (Passing through the Mediterraneum - role of the resting site in bird migration.) $165-177$

Ponyi Jenő: A Balaton rákfaunája (Crustacea) és változásai az elmúlt 100 évben. (The crustacean fauna of Lake Balaton and its changes during the last century.) ....... 179-189

Török János: Fehér foltok a madarak szexuális szelekciójában. (Signalization and sexual selection in the Collared Flycatcher.) 191-199

\section{8. kötet -2003}

1. füzet:

Pais István \& Sziráki György: In memoriam Dr. Ujhelyi Sándor (1902-1996). (In memoriam Dr. Sándor Újhelyi (1902-1996).) …................................................. 5-10

Korsós Zoltán: A fenetikus és kladisztikus osztályozás alapjai. (Phenetic and cladistic classifications: bases, principles, methods and rules.) ...................................... 11-36

Harka Ákos: A szivárványos ökle (Rhodeus sericeus Pallas, 1776) növekedése és produkciója a Tisza-tóban. (Growth and production of bitterling [Rhodens sericeus (Pallas, 1776)] in the storage-lake Tisza-tó (Eastern Hungary).) $37-49$

Kenyeres Zoltán \& Szinetár Csaba: Magyarország álkaszáspókjai (Araneae: Pholcidae). (Pholcidae in Hungary.) 51-60

Seres Anikó, Bakonyi Gábor \& Posta Katalin: Ugróvillások (Collembola) szerepe a Glomus mosseae (Zygomycetes) arbuszkuláris mikorrhiza gomba terjesztésében. (The role of Collembolan in spreading of arbuscular mycorrhiza.) $61-71$

Herczeg Gábor \& Korsós Zoltán: Az interspecifikus kompetíció hatása a pannongyíkra (Ablepharus kitaibelii fitzingeri) egy antropogén hatásoknak kitett élöhelyen. (Competition effect on the skink Ablepharus kitaibelii fitzingeri among human caused disturbance.) $73-84$

Sárospataki Miklós, Novák Judit \& Molnár Viktória: Hazai poszméh- és álposzméhfajok (Hymenoptera: Apidae, Bombus és Psithyrus) UTM-térképezése és az adatok természetvédelmi felhasználhatósága. (Mapping of the distribution of the bee species (Hymenoptera: Apidae, Bombus and Psithyrus spp.) in Hungary, and its possible application in nature conservation.) $85-108$

Kriska György \& Andrikovics Sándor: Az Electrogena lateralis Curt. kérészfajon élősködő Symbiocladius rhithrogene Kief. árvaszúnyog életmenetének vizsgálata. (Parasite relationship between the Symbiocladius rhithrogene and Electrogena lateralis larvae.) $109-116$

Bakonyi Gábor, Kiss István \& Seres Anikó: A magyar zoológusok névjegyzéke. (List of the Hungarian zoologists.) $117-148$ 
Rózsa Lajos, ifj.: Kassai Tibor (2003): Helmintológia. Medicina Könyvkiadó, Budapest. [Book review.]

2. füzet:

Rózsa Lajos: A madarak tetvei (Phthiraptera). (Avian Lice (Phthiraptera).) $3-29$

Nagy Barnabás: A Brunner-pókszöcske (Poecilimon brunneri Frivaldszky 1867; Orthoptera: Tettigonioidea) diszjunkt előfordulása a Kárpát-medence közepén. (Disjunct occcurrence of the Balkanian Poecilimon brunneri Frivaldszky, 1867; Orthoptera: Tettigonioidea) in the center of the Carpathian Basin.) 31-39

Hettyey Attila, Török János \& Kovács Tibor: Hét kétéltüfaj szaporodásbiológiája és élöhelyhasználata a Visegrádi-hegység területén. (Breeding biology and habitat use of seven amphibian species in a hilly woodland (Pilis Mountains, Hungary).) $41-55$

Hecker Kristóf, Bakó Botond \& Csorba Gábor: Új adatok a magyarországi pelefajok (Gliridae) elterjedéséhez. (New data on the distribution of the Hungarian dormouse species (Gliridae).) $57-67$

Szatyor Miklós, Estók Péter, Dombi Imre \& Somogyvári Orsolya: Ritka denevérfajok (Chiroptera) újabb előfordulásai Magyarországon. (Recent occurances of rare bat species (Chiroptera) from Hungary.) 69-72

Papp Jenő: Rovarvilág - CD-lemezen. [Book review.] 73-74

Nagy Péter: Az Állattani Szakosztály ülései (2002. november 6.-2003. december 14.). (Activity of the Zoological Society (from 06. November 2002 till 14. December 2003)) $75-83$

\section{9. kötet - 2004}

1. füzet:

Cserkész Tamás, Estók Péter \& Práger Anna: A magyar csíkos szöcskeegér (Sicista subtilis trizona Petényi, 1882). (The Hungarian southern birch mouse subspecies Sicista subtilis trizona (Petényi, 1882).) 3-16

Vilisics Ferenc \& Farkas Sándor: Összehasonlító faunisztikai vizsgálat a dél-dunántúli Babarcsszőlősi-pikkely ászkafaunáján (Isopoda, Oniscidea). (Ecofaunistical study on the terrestrial isopods (Isopoda, Oniscidea) of the Southern-Transdanubian Babarcszőlős hill in Hungary.) $17-25$

Horváth Győző, Pogány Ákos, Hamburger Krisztina \& Sárkány Henrik: A védett csalitjáró pocok, Microtus agrestis (Linnaeus, 1761) újabb csapdázásos adatai a Kis-Balaton területén. (New population data from trapping studies of the protected field vole Microtus agrestis (Linnaeus, 1761) in the Kis-Balaton marshland area.) $27-35$

Kenyeres Zoltán, Bauer Norbert \& Nagy Barnabás: Az Orthoptera együttesek és a habitatok változásai a Tihanyi-félszigeten az 1947. és 2001. évi felvételek alapján. (Differences in the Orthoptera assemblages in the Tihany Peninsula (W Hungary) based on 1947 and 2001 samplings.) 
Csatádi Katalin, Altbäcker Vilmos, Lengyel Enikő \& Bilkó Ágnes: A házinyúl szexuális viselkedése: intrauterin hatások. (Vulva colour and ano-genital distance as predictors of breeding status in the European rabbit (Oryctolagus cuniculus).) $55-66$

Somogyi Zoltán, Bakonyi Gábor \& Csathó Péter: A nátrium-szelenit hatása a közönséges televényféregre (Enchytraeus albidus Henle, 1837 Oligochaeta: Enchytraeidae). (The effect of the sodium-selenite on potworm (Enchytraeus albidus Henle, 1837 Oligochaeta: Enchytraeidae).) $67-71$

2. füzet:

Kiss Ottó: Vajon Imre 75 éves. (Imre Vajon is 75 years old.) 3-4

Horváth Győző: Az északi pocok (Microtus oeconomus) populáció monitorozása a KisBalaton területén. (Population monitoring of root voles (Microtus oeconomus) in the Kis-Balaton marshland area.) $5-16$

Hornung Erzsébet \& Tartally András: A Platyarthrus schoblii Budde-Lund 1885 (Isopoda: Oniscidea) és Lasius neglectus (Hymenoptera: Formicidae) együttes előfordulása Magyarországon. (The co-occurrence of Platyarthrus schoblii (Isopoda: Oniscidea) and Lasius neglectus (Hymenoptera: Formicidae) in Hungary.) $17-22$

Lanszki József: Somogyi lápok talajszinten élő emlős faunáinak vizsgálata. (Examination of terrestrial mammals of moors in Somogy County.) $23-30$

Herényi Márton, Török János, Garamszegi László Zsolt, Hargitai Rita, Hegyi Gergely, Michl Gábor, Rosivall Balázs, Szigeti Beáta \& Szöllősi Eszter: Másodlagos nemi jellegek és utódszám kapcsolata a hím örvös légykapóknál. (Secondary sexual characters and lifetime reproductive success in male collared flycatchers.) $31-41$

Heltai Miklós, Szűcs Eleonóra, Lanszki József \& Szabó László: Az aranysakál (Canis aureus Linnaeus, 1758) új elöfordulásai Magyarországon. (Latest data on the distribution of jackal in Hungary.) $43-52$

Dévai György, Gallé László, Izsák János, Tóthmérész Béla, Batáry Péter \& Papp László: Operativizálható-e a faunisztika? (Can faunistics be made operative?) ................ 53-81

Az Állattani Szakosztály ülései (2004. február 4.-2004. december 10.). (Activity of the Zoological Society (from 04. February 2004 till 10. December 2004).) ................ 83-86

\section{0. kötet - 2005}

1. füzet:

P. Zánkai Nóra: Új víziatkák a hazai faunában. (New water mite species in Hungarian fauna.) $3-10$

Lanszki József \& Horváth Győző: Ragadozó emlősök táplálkozási kapcsolatai a Lankóci erdőben (Somogy megye). (Trophic relations of carnivores in the Lankóci Forest (Somogy county).) $11-23$ 
Schäffer Dávid \& Purger J. Jenő: A barna ásóbéka (Pelobates fuscus) elterjedése Magyarországon. (Distribution of Common Spadefoot Toad (Pelobates fuscus) in Hungary.) 25-39

Cserkész Tamás: Bagolyköpetekből származó erdeiegér (Sylvaemus subgenus, Rodentia) koponyamaradványok összehasonlító kraniometriai vizsgálata: a fajok elkülönítése és a korcsoportok szerepe. (Comparative craniometrical analysis of subgenus Sylvaemus (Rodentia, genus Apodemus) based on cranial bones, collected from owl-pellets: determination of the species and the role of age-groups.) 41-55

Fehér György (2004): Állatpreparátumok készítése. V. kiadás, 341 old., 120 ábra. Mezőgazdasági Kiadó, Budapest. [Book review.]

2. füzet:

Nagy Barnabás, Sziráki György, Vásárhelyi Tamás \& Kondorosy Előd: Kis Béla (19242003) életútja és munkásságának méltatása. (In memoriam - Dr. Béla Kis (19242003).) $3-15$

Bókony Veronika, Liker András, Székely Tamás, Kis János \& Szentirmai István: A melanin alapú színezet funkciója madaraknál: a hódító fekete? (Adaptive significance of melanin-based plumage coloration in birds: a role for sexual signalling?) $17-28$

Sziráki György: A Baetis pentaphlebodes Ujhelyi, 1966 (Ephemeroptera, Baetidae) érvényes faj. (Baetis pentaphlebodes Ujhelyi, 1966 (Ephemeroptera: Baetidae) is a valid species.) 29-32

Bánszegi Oxána, Altbäcker Vilmos \& Bilkó Ágnes: Méhen belüli pozíció hatása a morfológiára és a viselkedésre házinyulaknál. (The effects of intrauterine position on morphology and behaviour of female rabbits.) $33-43$

Bódis Erika \& Oertel Nándor: Faunisztikai és ökológiai vizsgálatok a magyarországi Dunaszakasz kagylóin. (Faunistical and ecological research of mussel species in the Hungarian Danube section.) 45-61

Nyitrai Viktor, Németh István \& Altbäcker Vilmos: A külső hőmérséklet hatása a közönséges ürge (Spermophilus citellus) hibernációjára. (Effects of ambient temperature on hibernation in European ground squirrel (Spermophilus citellus).) 63-74

Heltai Miklós, Szőcs Emese, Balogh Viktor \& Szabó László: Adatok a nyest (Martes foina Erxleben, 1777) táplálkozásához és területhasználatához ember által zavart környezetben. (Study on the feeding habits and home range use of one stone marten (Martes foina Erxleben, 1777) specimen in an urban area.) $75-83$

Nagy Péter: Az Állattani Szakosztály ülései (2001. október 10.-2002. október 9.). (Activity of the Zoological Section (10 Oct. 2001-9 Oct. 2002).) 85-96

Nagy Péter: Az Állattani Szakosztály ülései (2005. február 2.-2005. december 7.). (Activity of the Zoological Section (2 Febr. 2005-7 Dec. 2005).) 97-106 


\section{1. kötet - 2006}

\section{1. füzet:}

Korsós Zoltán: Szerkesztői előszó. (Editorial foreword.) $3-4$

Halmágyi Levente \& Gippert Tibor: Holdas Sándor 75 éves. (Sándor Holdas is 75 years old.) $5-7$

Kovács Gábor, Szinetár Csaba \& Eichardt János: A márványos álkaszáspók (Holocnemus pluchei [Scopoli, 1763]) (Araneae: Pholcidae) Magyarországon. (Holocnemus pluchei (Scopoli, 1763) (Araneae: Pholcidae) in Hungary.) 9-18

Mátrai Norbert, Gyurácz József \& Bank László: A nádi tücsökmadár (Locustella luscinioides) őszi vonulása egy dél-magyarországi nádasban. (Autumn migration of Savi's Warblers (Locustella luscinioides) in a southern Hungarian reed-bed.) 19-28

Farkas Sándor: Tolna megye szárazföldi ászkarákfaunájának (Isopoda: Oniscidea) alapvetése. (Data to the knowledge of the terrestrial isopod (Isopoda: Oniscidea) fauna of Tolna County (Hungary: South Transdanubia).) $29-42$

Kozák Lajos \& Heltai Miklós: A borz (Meles meles Linnaeus, 1758) élőhely-preferenciája Hajdú-Bihar megyében. (Estmation of habitat preference of badger (Meles meles Linnaeus, 1758) in Hajdú-Bihar County, Hungary.) 43-55

Máthé István \& Balázs Enikő: Az emberi zavarás futóbogarakra gyakorolt hatásának vizsgálata Erdélyben. (The influence of human disturbance on carabids in Transsylvania, Roumania.) $57-68$

Nyírő Antal, Cheritach Laura, Altbäcker Vilmos \& Bilkó Ágnes: A korai szagtanulás tartósságának vizsgálata házinyulaknál. (Durability of early odour learning in the European domesticated rabbit.) 69-81

2. füzet:

Horváth Anna \& Martínez-Castellanos, Rafael: Élőhely-értékelés állatközösségek diverzitása alapján a dél-mexikói Montebello-i Tavak Nemzeti Parkban. (Evaluation of habitat-level conservation priorities based on the diversity of animal assemblages in the Lagos de Montebello National Park, South Mexico.) $95-116$

Laczi Miklós, Cserepes T. Mihály, Hegyi Gergely, Michl Gábor, Szigeti Beáta \& Török János: A tollazat UV-reflektanciája és a táplálkozás kapcsolata vizimadaraknál. (Relationship between UV-reflectance of plumage and feeding in waterbirds.) $117-126$

Ihász Nikolett, Bayer Katalin, Kopena Renáta, Molnár Orsolya, Herczeg Gábor \& Török János: Szemben a ragadozóval - a zöld gyík (Lacerta viridis) búvóhelyközpontú menekülési stratégiája. (Refuge-based escape behaviour in the Green Lizard (Lacerta viridis).) $127-138$

Bellaagh Mátyás, Korsós Zoltán \& Szelényi Gábor: A fokozottan védett haragos sikló (Hierophis caspius) új, Duna menti lelőhelyei Magyarországon. (New occurrences of the Caspian Whipsnake (Hierophis caspius) along the River Danube in Hungary.) 
Bálint Zsolt \& Gubányi András: A magyar csíkos szöcskeegér (Sicista subtilis trizona) (Mammalia: Rodentia, Dipodidae) felfedezéséről és nevezéktanáról. (On the discovery and nomenclature of Sicista subtilis trizona (Mammalia: Rodentia, Dipodidae).) $145-151$

Németh Attila, Csorba Gábor \& Farkas János: A hazai földikutyák (Spalax leucodon) kromoszóma-vizsgálatának módszertana és első eredményei. (First results and methodology of the karyology of the strictly protected Hungarian Lesser Blind Mole Rat (Spalax leucodon).) $153-157$

Nagy Péter \& Kontschán Jenő: Az Állattani Szakosztály ülései. (2006. február 1.-2006. december 6.). (Activity of the Zoological Society (from 1. Február 2006 till 6. December 2006).) $159-166$

\section{2. kötet - 2007}

1. füzet:

Csuzdi Csaba: Magyarország földigiliszta-faunájának áttekintése (Oligochaeta, Lumbricidae). (A review of the Hungarian earthworm fauna (Review).) ............... 3-38

Hankó Eszter Piroska \& Korsós Zoltán: Pleisztocén oroszlánok fog- és állkapocsmorfológiai jellegeinek kladisztikus analízise. (A cladistic analysis of the teeth and mandible morphological characters of Pleistocene lions from Hungary.) 39-51

Nagy Antal \& Rácz István András: Egyenesszárnyúak (Orthoptera) védelmének élőhelyi és faji prioritásai az Aggteleki Nemzeti Parkban. (Setting priorities for conservation of the Orthoptera species in the Aggtelek National Park (Northeast Hungary).) 53-65

Lanszki József, Sugár László \& Orosz Enikő: Hazai vidrák morfológiai jellemzői és elhullási okai post mortem vizsgálat alapján. (Morphologic parameters and death causes of otters in Hungary, by means of post mortem analysis.) $67-76$

Bánszegi Oxána, Szetei Viktória, Altbäcker Vilmos, Németh István \& Bilkó Ágnes: A vemhesség alatt adott extra tesztoszeron hatása az utódok ivari differenciációjára házinyulaknál. (Effect of extra prenatal testosterone on rabbit offspring at birth.) $77-86$

2. füzet:

Móczár László: 300 éve született Carl von Linné (1707-1778). (Carl von Linné was born 300 years ago (In memoriam).) 3-9

Horváth Roland \& Szinetár Csaba: Az urbanizáció hatása talajlakó pókokra alföldi erdőfoltokban. (Effect of urbanisation on ground-dwelling spiders in lowland forest patches.) $11-25$

Bellaagh Mátyás, Deákné Lazányi-Bacsó Eszter Ágnes \& Korsós Zoltán: Fluktuáló aszimetria vizsgálata hüllőpopulációk életminőségének jellemzésére. (Fluctuating asymmetry as a character to life quality in three different snake populations.) ...... 27-36

Mátrai Norbert, Gyurácz József, Mátics Róbert \& Bakonyi Gábor: A nádirigó (Acrocephalus arundinaceus) lehetséges telelöterületei az EURING adatbázisának afri- 
kai megkerülési adatai alapján. (Potential wintering areas of great reed warblers (Acrocephalus arundinaceus) based on the recapture data of the EURING databank.) $37-44$

Harkai Anikó \& Molnár Nóra: Aphis gossypii (Sternorrhyncha: Aphididae) kolonizációs jellegzetességei selyemkóró-állományokban. (Colony traits of Aphis gossypii (Sternorrhyncha: Aphididae) feeding on milkweed.) $45-57$

Déri Eszter, Horváth Roland, Lengyel Szabolcs, Nagy Antal \& Varga Zoltán: Zoológiai kutatások a gépi kaszálás hatásának vizsgálatára hat magyarországi tájegységben. (Zoological studies on the effects of mowing in six regions of Hungary.) $59-70$

Bauer Barbara \& Jordán Ferenc: Szerkezet és funkció összefüggései egy alaszkai öböl táplálékhálózatában. (Structure and function in an ecosystem - a food web study (Prince William Sound, Alaska).) $71-78$

Mizser Szabolcs: Futóbogarak előfordulási mintázata egy urbanizációs élőhelygrádiens mentén. (Patterns of carabid beetles along an urban-rural gradient.) 79-90

Papp László, Bakonyi Gábor, Báldi András, Podani János \& Tóthmérész Béla: Publikálás a szupraindividuális biológiában. (Publication opportunities in supra-individual biology.) 91-120

\section{3. kötet - 2008}

\section{1. füzet:}

Kontschán Jenő: Magyarország korongatkái (Acari: Mesostigmata: Uropodina). (Turtle mites of Hungary (Acari: Mesostigmata: Uropodina).) $3-15$

Lakatos András, Főző Rita, Hegyi Gergely \& Török János: Tollazati szignálok és anyai hatás vizsgálata széncinegéknél (Parus major). (Plumage colour signals and maternal effects in the Great Tit (Parus major).) $17-28$

Lanszki József, Mórocz Attila \& Deme Tamás: Adatok három vizes élőhely (Gemenc, Béda és a balatoni Nagyberek) kisemlősfaunájához. (Data for small mammal fauna of three wetlands (Gemenc, Béda, and the Nagyberek at Lake Balaton).) 29-37

Kolics Balázs, Nagy Barnabás, Kondorosy Előd, Puskás Gellért \& Müller Tamás: A fürészlábú szöcske (Saga pedo Pallas, 1771) életciklusa és magyarországi előfordulása. (The life cycle of Saga pedo Pallas, 1771 and its distribution in Hungary.) $39-52$

Dúcs Anita, Altbäcker Vilmos \& Bilkó Ágnes: Az anya állapota és utódai kezelése is befolyásolja a házinyúl félelmi szintjét. (Both maternal condition and early handling influence the fear level of weanlings in the domestic rabbit.) 53-63

Purger J. Jenö: Öreglak, Kürtöspuszta, Törökkoppány és Kazsok környékének (Somogy megye), valamint az általuk határolt térség kisemlősfaunájának vizsgálata, gyöngybagoly- (Tyto alba (Scopoli, 1769)) köpetek alapján. (Small mammal fauna of the region between Öreglak, Kürtöspuszta, Törökkopány and Kazsok környékének (Somogy county, Hungary), based on Barn Owl (Tyto alba (Scopoli, 1769)) pellet analysis.) $65-76$ 
2. füzet:

Vilisics Ferenc \& Hornung Erzsébet: A budapesti szárazföldi ászkarákfauna (Isopoda: Oniscidea) kvalitatív osztályozása. (Qualitative classification of the terrestrial isopod fauna (Isopoda: Oniscidea) of Budapest, Hungary).) 3-16

Havas Enikő, Sárospataki Miklós \& Józan Zsolt: Új adatok a Tihanyi-félsziget vadméhfaunájával kapcsolatban. (New data on Apoid fauna of Tihany Peninsula.) $17-24$

Kisfali Máté \& Nagy Antal: Középtávú orthopterológiai vizsgálatok a Villányi-hegységben (1999-2005). (Medium-term orthopterological studies in the Villány hills (19992005).) 25-38

Sólymos Péter, Vilisics Ferenc \& Hornung Erzsébet: Terepi adatlap a hazai epigeikus makrogerinctelenek elterjedésének és élőhelyi preferenciájának vizsgálatára. (Datasheet for habitat feature assessment of field surveys on epigeic macroinvertebrates.) .... 39-46

Hotzi Virág, Markov, Georgi, Csorba Gábor \& Gubányi András: Nyomozás a kelet-európai pocok (Microtus levis) után Magyarországon. (Taking steps to discover the EastEuropean vole (Microtus levis) in Hungary.) $47-57$

Weiperth András, Keresztessy Katalin \& Sály Péter: A Tapolcai-medence patakjainak halfaunisztikai vizsgálata. (Fish fauna monitoring in the Tapolca Basin.) $59-70$

Szeder Balázs, Simon Barbara, Dombos Miklós \& Szegi Tamás: Talajdegradációs folyamatok hatása az ugróvillások (Collembola) közösségeire. (The impact of soil degradation processes on Collembola community.) $71-77$

Harka Á. (szerk.) (2007): Pisces Hungarici II. - A Magyar Haltani Társaság időszakos kiadványa. 162 pp.. (Book reference.) 79

Kontschán Jenő: Az Állattani Szakosztály ülései (2007. január 19.-2008. december 3.). (Activity of the Zoological Society (19. 01. 2007.-03. 12. 2008.)) 81-92

\section{4. kötet - 2009}

1. füzet:

Bakonyi Gábor, Seres Anikó, Répási Viktória, Juriková Tünde, Szekeres László \& Balla István: Új irányok a talajállatok ökotoxikológiájában. (New directions for research into the ecotoxicology of soil animals (Review paper).) 3-17

Dózsa-Farkas Klára: Zicsi András vezette kutatások az Aggteleki Barlangbiológiai Laboratóriumban. Zicsi András köszöntése 80. születésnapja alkalmából. (Researches in the Cave Laboratory of Aggtelek led by Dr. András Zicsi.) $19-28$

Dányi László: Magyarország százlábúi (Chilopoda) I. A taxonómiai bélyegek áttekintése. (Centipedes (Chilopoda) of Hungary I. Overview of taxonomical characters.) .... 29-53

Kováts Dávid, Urbán Helga \& Varga Zoltán: Szimpatrikus övezetben költő fülemülék morfológiai összehasonlítása. (Morphological comparison of the Nightingales in a sympatric zone in Hungary.) 
Havas Enikő, Répási Viktória, Staszny Ádám \& Sárospataki Miklós: A magyarországi Chelostoma-fajok (Hymenoptera: Megachilidae) elterjedési és előfordulási gyakoriságának időbeni változása. (Changes in the relative distribution frequency and occurence of Chelostoma species (Hymenoptera: Megachilidae) in Hungary.) 63-72

Sály Péter, Takács Péter \& Erős Tibor: Halfaunisztikai vizsgálatok Borsod-Abaúj-Zemplén megye északi térségében. (Fish faunistical surveys in the northern region of BorsodAbaúj-Zemplén County, Hungary.) 73-91

Horváth Zsófia, Forró László, Szövényi Gergely \& Andrikovics Sándor: Kisrákegyüttesek (Crustacea: Cladocera, Copepoda) vizsgálata a hansági Nyirkai-Hany vizes élőhelyrekonstrukciós területen. (Microcrustacean (Crustacea: Copepoda, Cladocera) assemblages in the Nyirkai-Hany wetland reconstruction area (Fertö-Hanság National Park, Hungary).) 93-102

Rácz Márta Judit, Kiss István \& Sály Péter: Kétéltüállományok összehasonlító vizsgálata Budapest különböző vizes élőhelyein. (Comparative study of amphibian assemblages in different wetland habitats at Budapest.) $103-121$

Harka Á. (szerk.) (2009): Pisces Hungarici III. A Magyar Haltani Társaság időszakos kiadványa. pp. 182. [Book review.]

2. füzet:

Horváth László, Csorbai Balázs, Urbányi Béla \& Tamás Gizella: Néhány halfaj ivadékának táplálkozási adaptációja a zooplankton-kínálathoz. (Feeding adaptation of several fish species to the available zooplankton (Review paper).) 131-145

Nagy Barnabás: Ritka domb- és hegyvidéki fajok Deliblát Orthoptera-faunájában. (Detection of rare, sub-mountain Orthoptera species on the S Pannonian Plain: Deliblat sand-dunes (Serbia/Vojvodina).) 147-157

Staszny Ádám, Ferincz Árpád, Weiperth András, Havas Enikő, Paulovits Gábor \& Urbányi Béla: Pikkely-morfometriai vizsgálatok halfajok, illetve populációk elkülönítésére. (Scale-morphometry studies to discriminate fish species and populations.) ...... 159-166

Bajer Katalin, Molnár Orsolya, Hegyi Gergely, Herczeg Gábor, Laczi Miklós \& Török János: Zöld gyíkok színezete és morfológiája: jelzések és funkciók. (An experimental test of sexual selection on colour and morphology in green lizards.) $167-176$

Hegyi Árpád, Tóth Balázs, Béres Tibor, Oláh Károly \& Urbányi Béla: Újabb adatok az ezüstkárász (Carassius gibelio (Bloch, 1782)) populációk ivararányáról. (Recent data about the sex profile of Prussian carp (Carassius gibelio (Bloch, 1782).) ......... 177-185

Szabó László, Heltai Miklós \& Lanszki József: Az aranysakál állománysürüségének változása a hajós-szentgyörgyi erdőben 2004 és 2009 között. (Changing of the golden jackal's population density in the forest of Hajós-Szentgyörgy between 2004 and 2009.) 187-197

Weiperth András, Szivák Ildikó, Ferincz Árpád, Staszny Ádám, Keresztessy Katalin \& Paulovits Gábor: A vízszintingadozás hatása a balatoni halász-horgász fogások alakulására. (Effects of water level fluctuation on fisch catch in Lake Balaton.) 199-213 
Puskás Katalin: Vezényi Árpádról és az ő "Délamerikába történő utazásán" készült fényképeiről. (Árpád Vezényi and his photographs, taken on his zoological travel to South America.) 215-236

Kontschán Jenő: Az Állattani Szakosztály ülései (2009. január 7.-2009. december 2.). (Activity of the Zoological Society (from $7^{\text {th }}$ January 2009, until $2^{\text {nd }}$ December 2009).) 237-243

Bogsch Ilma: Eckhard Grimmberger, Klaus Rudloff (Christian Kern közremüködésével) (2009): Atlas der Säugetiere Europas, Nordafrikas und Vorderasiens. Natur und TierVerlag GmbH, Münster, 469 oldal, 1094 színes kép, 437 elterjedési térkép. (Book references.)

\section{5. kötet - 2010}

1. füzet:

Dányi László: Magyarország százlábúi (Chilopoda) II. Határozókulcs. (Centipedes (Chilopoda) of Hungary II. Identification key.)

Horváth Ákos, Martínez Páramo, Sonia, Kovács Ákos István, Urbányi Béla \& Herráez, Paz: A ponty (Cyprinus carpio Linnaeus) ovariális folyadékának hatása a friss és mélyhütött pontysperma motilitására. (Effect of ovarian fluid on the motility of fresh and cryopreserved sperm of the common carp (Cyprinus carpio Linnaeus).) 25-33

Kolics Balázs, Zilay Tamás, Chobanov, Dragan, Kolics-Horváth Éva \& Müller Tamás: A magyarországi fauna kipusztult szöcskeóriása: a tüskéslábú pozsgóc (Bradyporus dasypus). Összefoglaló a faj biológiájáról, a tartásáról és visszatelepítésének lehetőségeiröl. (Bradyporus dasypus, the extinct giant katydid of the Hungarian fauna. A summary on the biology, breeding, and possibilities of reintroduction of the species.) ......... 35-46

Horváth Boglárka, Kovács Szilvia, Répási Viktória, Márton Anita \& Nagy Péter: Eltérő taxonómiai helyzetű növényi fonálférgek akut krómszennyezés iránti érzékenységének tesztelése. (Testing sensitivity of plant-feeding nematodes of different taxonomic position to acute chromium stress.) 47-55

Buczkó Máté \& Heltai Miklós: Egy új, nem-invazív emlőshulladék-jelölési módszer kidolgozása és vizsgálata. (Development and evaluation of a new non-invasive method for marking mammal faeces.) $57-72$

Bán Gergely, Pintér Adrienn, Fetykó Kinga, Orosz Szilvia, Veres Andrea \& Tóth Ferenc: A betelepített vegyes ízeltlábú-együttes felhasználási lehetősége a hajtatott paprika biológiai védelmében. (The potential of artificially introduced arthropod assemblages in the biological control of greenhouse pepper.) 73-86

Vilisics Ferenc \& Hornung Erzsébet: Újabb adatok Magyarország szárazföldi ászkarákfaunájához (Crustacea, Isopoda, Oniscidea). (New data to the terrestrial isopod (Crustacea, Isopoda, Oniscidea) fauna of Hungary.) $87-120$

Vörös Judit, Dankovics Róbert, Harmos Krisztián, Dobay Gergely \& Kiss István: A foltos szalamandra (Salamandra salamandra) elöfordulása és természetvédelmi helyzete Ma- 
gyarországon. (Distribution and conservation status of the fire salamander (Salamandra salamandra) in Hungary.) 121-149

Kováts Nóra, Nassr-Allah, Abdel-Hameid, Ács András, Kárpáti Árpád \& Paulovits Gábor: Kommunális szennyvíz ökotoxicitásának becslése lapos tavikagyló (Pseudanodonta complanata) lárváival. (Assessing ecotoxicity of municipal wastewater on Pseudanodonta complanata glochidia.) $151-154$

Pisces Hungarici IV. [Könyvismertetés]. (Book review.) 155

2. füzet:

Vörös Judit \& Kiss István: Elöszó. [Foreword.]

Dobay Gergely \& Kiss István: A foltos szalamandra (Salamandra salamandra L.) populációbiológiai vizsgálata a Selmeci-hegységben (Szlovákia). (Survey of a Salamandra salamandra L. population in the Selmec Mountains (Slovakia).) $165-177$

Babocsay Gergely: A molekuláris és morfológiai módszerek előnyei és hátrányai a rendszertani kutatásokban; egy toxikus példa, avagy az arab fürészpettyes-vipera (Echis coloratus) fajcsoport esete. (Molecular versus morphological methods in taxonomy; a toxic case: the Echis coloratus complex.) 179-190

Hock Ferenc, Huszty Csaba, Szövényi Gergely \& Vörös Judit: Magyarországi sárgahasú unka-populációk (Bombina variegata) összehasonlító bioakusztikai vizsgálata. (Comparative bio-acoustic study of Hungarian populations of the yellow-bellied toad (Bombina variegata).) 191-206

Kovács Tibor, Vági Balázs \& Török János: Ökológiai átjárók kihasználtságának vizsgálata autópályák alatt. (Utilization of frog tunnels under motorways in Hungary.) .... 207-222

Halpern Bálint, Tóth Csilla, Brankovits Dávid, Péchy Tamás \& Major Ágnes: A rákosi vipera (Vipera ursinii rakosiensis) tenyészprogram eredményei 2004 és 2009 között. (Results of the captive breeding project of Hungarian Meadow Viper (Vipera ursinii rakosiensis).) $223-237$

Péchy Tamás \& Halpern Bálint: Mesterséges telelöüreg kétéltűek és hüllők számára. (Artificial burrow for hibernation of amphibians and reptiles.) 239-252

Gubányi András, Vörös Judit, Kiss István, Dankovics Róbert, Babocsay Gergely, Kovács Tibor, Molnár Péter \& Somlai Tibor: Az alpesi tarajosgőte (Triturus carnifex), a dunai tarajosgőte (T. dobrogicus) és a vöröshasú unka (Bombina bombina) magyarországi elterjedésének elemzése. (Contribution to knowledge of the distribution of Italian Crested Newt (Triturus carnifex), Danube Crested Newt (T. dobrogicus) and European Firebelled Toad (Bombina bombina) in Hungary.) 253-279

Kiss István, Babocsay Gergely, Dankovics Róbert, Gubányi András, Kovács Tibor, Molnár Péter, Somlai Tibor \& Vörös Judit: Kiválasztott Natura 2000 fajok (Triturus carnifex, $T$. dobrogicus és Bombina bombina) monitorozását előkészítő felmérések. (A preparative survey for monitoring of selected Natura 2000 amphibian species (Triturus carnifex, $T$. dobrogicus and Bombina bombina ) in Hungary.) 281-304

Varga János: Részlegesen albínó foltosszalamandra-lárva észlelése Magyarországon. (A partially albinistic fire salamander larva (Salamandra salamandra) in Hungary.) 305-309 
Brankovits Dávid, Halpern Bálint, Vidéki Róbert, Katona Krisztián \& Szövényi Gergely: A rákosi vipera (Vipera ursinii rakosiensis Méhely, 1893) egyes kiskunsági élőhelyeinek monitorozása és minőségi elemzése a vizsgált jellemzők alapján. (Monitoring and qualification of the Hungarian Meadow Viper's (Vipera ursinii rakosiensis) certain habitats in the Kiskunság.) 311-325

Antal Zsuzsanna \& Juhász Lajos: Herpetofaunisztikai adatok a Hajdúbagosi Földikutya Rezervátum Természetvédelmi Területéröl. (Herpetofaunistic surveys in the Lesser Mole Rat Reserve of Hajdúbagos Nature Conservation Area.) $327-332$

\section{6. kötet - 2011}

1-2. füzet:

Boros Gergely: A magyarországi televényféreg-kutatás négy és fél évtizede. Dózsa-Farkas Klára köszöntése 70. születésnapja alkalmából. (45 years in the research of enchytraeid worms in Hungary.) 3-13

Novák János \& Dányi László: A Lithobius stygius infernus Loksa, 1948 taxonómiai helyzetének tisztázása. (Clarification of the taxonomical status of Lithobius stygius infernus Loksa, 1948.) $15-22$

Tóth Ágnes \& Elekes Attiláné: Első jelentés a Bursaphelenchus mucronatus és B. vallesianus (Nematoda: Parasitaphelenchidae) magyarországi jelenlétéről tűlevelü fajokon. (First report on the presence of Bursaphelenchus mucronatus and B. vallesianus (Nematoda: Parasitaphelenchidae) on coniferous species in Hungary.) 23-38

Tóth Mária, Bárány Annamária \& Szenczi Péter: A nyest Budapesten. (The Stone Marten in Budapest.) 39-59

Vargha Béla: A Magyarországon előforduló medveállatkafajok (Tardigrada) és lelőhelyeik. (Hungarian Tardigrade (Tardigrada) species and their localities.) 61-87

Kemencei Zita, Hornung Erzsébet, Vilisics Ferenc \& Sólymos Péter: Élőhelyek természetvédelmi értékelése szárazföldi csigák segítségével erdőrezervátumok példáján bemutatva. (Habitat quality assessment for biological conservation based on land snails: a case study from forest reserves.) 89-98

Pipoly Ivett, Bókony Veronika \& Liker András: Hogyan befolyásolja az időjárás a házi verebek (Passer domesticus) fiókaetetési viselkedését? (How do weather conditions influence the chick-feeding behaviour of House Sparrows (Passer domesticus)?) 99-112

Ottlecz Barnabás, Spakovszky Péter \& Heltai Miklós: A molnárgörény (Mustela eversmanii) magyarországi előfordulási adatainak összegzése. (Assessment of the Steppe Polecat occurrence (Mustela eversmanii) in Hungary.) $113-123$

Várkonyi Emese Éva \& Jancsik Veronika: A sokszínű melanin-koncentráló hormon. (The multi-faceted melanin-concentrating hormone.) $125-135$ 
Kontschán Jenő \& Vilisics Ferenc: A Magyar Biológiai Társaság Állattani Szakosztályának ülései (2010. február 3.-2010. december 1.). (Activity of the Zoological Section (from $3^{\text {rd }}$ February 2010. till $1^{\text {st }}$ December 2010.).) $137-143$

Lazányi Eszter: A Magyar Biológiai Társaság Állattani Szakosztályának ülései (2011. február 2.-2011. december 7.). (Activity of the Zoological Section (from $2^{\text {nd }}$ February 2011. till $7^{\text {th }}$ December 2011.).) $145-160$

\section{7. kötet - 2012}

1. füzet:

Vörös Judit \& Kiss István: Előszó a III. Herpetológiai Előadóülés megjelenő előadásaihoz. (Foreword to the published lectures of the III. Herpetological Meeting.)

Simon Edina, Puky Miklós \& Braun Mihály: Anura-fajok elemösszetételének elemzése ujjpercek alapján. (Toebone-based elemental content of anurans.) $5-14$

Bády Ferenc \& Vági Balázs: A fali gyík (Podarcis muralis Laurenti, 1768) aktivitása és termoregulációs viselkedése urbanizált és természetközeli élöhelyen. (Activity and thermoregulatory behaviour of the common wall lizard (Podarcis muralis Laurenti, 1768) in urban and natural habitats.) $15-30$

Nagy Krisztián, Babocsay Gergely \& Gallé László: A legeltetés mint környezeti stressz hatása szimpatrikus gyíkpopulációkra. (The effect of grazing as an environmental stress on sympatric lizard populations.) $31-46$

Gál Júlia Tünde, Szabó Krisztián \& Vörös Judit: Kitridiomikózis vizsgálata egy magasbakonyi vizes élőhely kétéltüközösségén. (Survey on Batrachochytrium dendrobatidis in an amphibian community in Bakony Mountains, Hungary.) 47-60

Deák Gábor, Sály Péter \& Kiss István: A Triturus dobrogicus és Lissotriton vulgaris gőtefajok állománydinamikája és élőhelyhasználata a szaporodóhelyen. (Population dinamic and habitat use of Triturus dobrogicus an Lissotriton vulgaris at the breeding site.) $61-76$

Mechura Tímea, Gémesi Dorottya, Szövényi Gergely \& Puky Miklós: A tavaszi kétéltüvándorlás időbeli jellegzetességei és a közúti kétéltüvédelmi rendszer müködése a 2. sz. foút Hont-Parassapuszta szakaszán 2009 és 2011 között. (Temporal characteristics of the spring amphibian migration and the use of the tunnel-barrier system along the Hont and Parassapuszta section of the main road No. 2. between 2009 and 2011.) ....... 77-84

Faggyas Szabolcs \& Puky Miklós: Az ACO Wildlife Pro kétéltűátjáró-rendszer első magyarországi alkalmazásának kivitelezési tapasztalatai és a monitorozás első eredményei. (Construction and preliminary monitoring results of the first ACO Wildlife Pro amphibian mitigation systems on roads in Hungary.) 85-94

Flórián Norbert, Kavecsánszki Alexandra, Németh András \& Hufnagel Levente: Kétéltüek élőhelyhasználat-változásai a Tápió-Hajta vidékén. (Habitat preference of amphibians at the Tápió-Hajta Region and its relation to short-term climate impacts.) ........ 95-108 
2. füzet:

Rőszer Tamás: Dr. Hollósi Gábor (1935-2012) emlékezete. (In memoriam Dr. Gábor Hollósi (1935-2012).) $117-120$

Faragó Sándor: In memoriam Sterbetz István (1924-2012). (In memoriam István Sterbetz (1924-2012).) $121-128$

Dózsa-Farkas Klára: Dr. Andrássy István (1927-2012) tudományos munkássága. (Scientific activity of Dr. István Andrássy (1927-2012).) $129-132$

Bakonyi Gábor: Az utód búcsúja a Főszerkesztőtől. (Successor's farewell from the Editorin-Chief.)

Nagy Péter: Jubileumi köszöntő. (Celebrating the jubilee.) $135-138$

Korsós Zoltán: Ezer ülés, 121 év. Az Állattani Szakosztály üléseinek rövid története. (One thousand sessions, 121 years. A brief history of the lectures in the Zoological Section.) $139-178$

Angyal Dorottya: Újabb adatok a magyar vakcsiga (Bythiospeum hungaricum (Soós, 1927); Gastropoda, Hydrobiidae) elterjedéséről az élőhelyében bekövetkezett változások tükrében. (New data about the distribution of the Hungarian Blind Snail (Bythiospeum hungaricum (Soós, 1927); Gastropoda, Hydrobiidae) in reflection of the changes of the species' habitat.) $179-186$

Szanyi Szabolcs: A Nagydobronyi Vadvédelmi Rezervátum és környéke nagylepke-faunája (Macrolepidoptera). (Data to the Macrolepidoptera fauna of the Nagydobrony Game Reserve (Transcarpathian region, Beregi-lowland).) $187-196$

Sály Péter, Takács Péter, Kiss István, Bíró Péter \& Erős Tibor: Lokális és tájléptékü tényezők hatása a jövevény halfajok elterjedésére a Balaton vízgyüjtőjének kisvízfolyásaiban. (Effect of local- and landscape-scale factors on the distribution of non-native fishes in small watercourses of the catchment area of Lake Balaton (Hungary).) $197-216$

Lovász Zsófia, Kovács Tibor, Sály Péter \& Kiss István: A mocsári teknős (Emys orbicularis) térbeli és időbeli aktivitásmintázata a Naplás-tavon. (Spatial and temporal activity patterns of Europaean pond turtle (Emys orbicularis L.) in Lake Naplás.) $217-228$

Péntek Attila László \& Ronkayné Tóth Mária: Városi parkok mint vörös mókus (Sciurus vulgaris Linnaeus, 1758) menedékek. (Urban parks as refuges of red squirrel (Sciurus vulgaris Linnaeus, 1758).) $229-242$

Lazányi Eszter: A Magyar Biológiai Társaság Állattani Szakosztályának ülései (2012. február 8-2012. december 5.). (Activity of the Zoological Section of the Hungarian Biological Society (from 8. February 2012. till 5. December 2012.).) $243-264$ 
98. kötet - 2013

\section{1-2. füzet:}

Nagy Péter István: Emlékezés Balogh Jánosra (1913-2002). (In memoriam Balogh János (1913-2002).) 3-5

Horváth Edit \& Kontschán Jenő: Balogh János élete, munkássága és a Magyar Természettudományi Múzeum Balogh-gyüjteménye. (János Balogh's life and work, and the Balogh Collection housed in the Hungarian Natural History Museum.) 7-20

Vidacs Júlia Anna, Farkas János \& Németh Attila: Konvergenciák, divergenciák és adaptáció a talajlakó életmódot folytató emlősöknél. (Convergence, divergence and adaptation in subterranean mammals.) $21-46$

Dudás Péter, Ambrus Gergely, Piltz Magdolna \& Tóth Ferenc: Avartakarással kezelt és kezeletlen burgonyatáblák százlábú együtteseinek (Chilopoda) felmérése talajcsapdázással. (Analysis of centipede (Chilopoda) assemblages by pitfall trapping of mulched and non-mulched potato plots using leaf litter.) 47-56

Farkas Roland \& Fehér Zoltán: A dobozi pikkelyescsiga (Kovacsia kovacsi [Varga \& Pintér, 1972]) elterjedésének vizsgálata a Zempléni-hegységben. (Study on the distribution of Kovacsia kovacsi (Varga \& Pintér, 1972) in the Zemplén mountains (Northern Hungary).) $57-64$

Nemesházi Edina, Horváth Zoltán, Mórocz Attila, Mikuska Tibor, Tihanyi Gábor \& Szabó Krisztián: A Kárpát-medence rétisas-populációjának (Haliaeetus albicilla) filogeográfiai és populációgenetikai vizsgálata. (Philogeography and population genetics of the White-tailed Eagle (Haliaeetus albicilla) in the Carpathian Basin.)

Ottucsák Marianna, Varga Gábor \& Bakonyi Gábor: Települési szennyvíz tisztítása során keletkező rácsszemétkomposzt akut toxicitási vizsgálata trágyagiliszta (Eisenia fetida) tesztszervezettel. (Acute toxicity analysis of compost from municipal sewage treatment with red earthworm (Eisenia fetida) testorganism.) $81-88$

Kontschán Jenő: Újabb adatok a Discourellidae (Acari: Uropodina) család fajainak erdélyi (Románia) előfordulásaihoz. (New records of family Discourellidae (Acari: Uropodina) in Transylvania (Romania).) 89-95

Szanyi Szabolcs, Debnár Zsuzsanna, Nagy Antal, Rácz István András \& Varga Zoltán: Fragmentált gyepek három védett egyenesszárnyú fajának (Orthoptera) metapopulációhálózata az Aggteleki-karszton. (Metapopulation network of three protected grasshopper species (Orthoptera) on the Aggtelek karst.) 97-110

Balázs Gergely \& Angyal Dorottya: A magyarországi vakbolharákfajok (Amphipoda: Niphargus spp.) értékelö irodalmi áttekintése. (Critical overview of the literature of Hungarian Niphargus (Amphipoda) species.) 111-119

Novák János: Adatok Magyarország álskorpió-faunájához. (Contribution to the pseudoscorpion fauna of Hungary.) 
Kontschán Jenő: Erdély atkafaunája és Mahunka Sándor szerepe Erdély atkafaunájának feltárásában. (Mite fauna of Transylvania (Romania) and Sándor Mahunka's role in the investigation of the Transylvanian mite fauna.) 131-138

Lazányi Eszter \& Angyal Dorottya: A Magyar Biológiai Társaság Állattani Szakosztályának ülései (2013. február 6.-2013. december 4.). (Activity of the Zoological Section of the Hungarian Biological Society (from 8. February 2012. till 5. December 2012.).) 139-159

\section{9. kötet - 2014}

\section{1-2. füzet:}

Korsós Zoltán: Száz éve hunyt el A. R. Wallace (1823-1913) angol természettudós. (A. R. Wallace (1823-1913) British naturalist died one-hundred years ago.)

Kiss István: Dr. Bogsch Ilma emlékezete (1942-2014). (In memoriam dr. Dr. Ilma Bogsch (1942-2014).)

Szentesi Árpád \& Tóth Miklós: Elment Jermy Tibor (1917-2014). (To the memory of Tibor Jermy (1917-2014).)

Samu Ferenc: Jermy Tibor (1917-2014) akadémikus emlékére. (In memoriam Tibor Jermy (1917-2014), member of the Hungarian Academy of Sciences.)

Szabó Barbara, Nagy Barnabás \& Szentkirályi Ferenc: Egyenesszárnyú rovarfajok (Orthoptera) lárvakeléskezdeteinek hosszú távú trendjei (1958-2009) az éghajlatváltozás következményeként Magyarországon. (Long-term changes (1958-2009) in hatching time of grasshopper (Orthoptera) species - consequences of climate change in Hungary.)

Tanács Lajos: A 100 éves dr. Móczár László professzor úr köszöntése és szakmai életútjának ismertetése. (Celebration of Prof. dr. László Móczár's 100th birthday, and a short summary of his activities.)

Angyal Dorottya \& Dányi László: Az Állattani Szakosztály ülései (2014. február 5.-2014. december 3.). (Activity of the Zoological Section of the Hungarian Biological Society (from $5^{\text {th }}$ February 2014 till $3^{\text {rd }}$ December 2014).)

\section{0. kötet -2015}

\section{1-2. füzet:}

Korsós Zoltán: Szerkesztői búcsú. (Editorial farewell.)

Dózsa-Farkas Klára \& Csuzdi Csaba: Búcsú Zicsi András professzortól. (1928-2015). (Final farewell to Prof. András Zicsi.) 
Markó Viktor: Utazás a közösségi ökológia forrásvidékére - Szelényi Gusztáv agrozoocönológiája és a Balogh-Szelényi-vita. (Journey to the sources of community ecology - Gusztáv Szelényi's agrozoocoenology and the Balogh-Szelényi debate.) . 29

Suták Anita \& Kontschán Jenő: Újabb adatok egyes páncélosatka-családok (Acari: Oribatida) fajainak erdélyi (Románia) előfordulásaihoz. (Contribution to distribution of some families of Oribatida (Acari) in Transylvania (Romania).) 55

Kiss Lola Virág, Hrács Krisztina, Nagy Péter István \& Seres Anikó: Különböző szemcseméretű cink-oxid hatása talajlakó ugróvillás és fonálféreg tesztszervezetekre. (The toxic effects of different particle sized zinc oxide on terrestrial springtail and nematode test organisms.)

Szanyi Szabolcs, Szőcs Levente, Csóka György \& Varga Zoltán: A Beregi-sík Noctuoidea (Lepidoptera: Macroheterocera) faunájának állatföldrajzi és ökológiai jellemzése. (The Noctuoidea (Lepidoptera: Macroheterocera) fauna of the Bereg Plain.) 89

Gyuris Enikő: Ízeltlábúak személyiségjegyekkel. (Personality traits in arthropods.) ...... 101

Zombor Katalin \& Tóth Mária: Mivel táplálkozik a vörös vércse (Falco tinnunculus Linnaeus, 1758) Budapesten? (What the kestrels (Falco tinnunculus Linnaeus, 1758) feed on in Budapest?)

Az Állattani Közlemények 1-100. köteteinek tartalomjegyzéke. (Contents of the 100 volumes of Állattani Közlemények.)

Angyal Dorottya: Az Állattani Szakosztály ülései (2015. március 4.-2015. december 2.). (Activity of the Zoological Section of the Hungarian Biological Society (from $4^{\text {th }}$ March 2015 till $2^{\text {nd }}$ December 2015).) 